


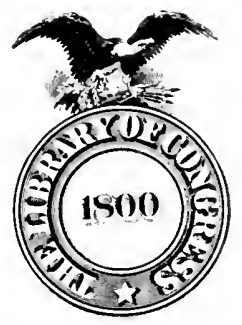


. 




\section{HIGHWAYS AND BYWAYS OF THE MISSISSIPPI VALLEY}


The 我 



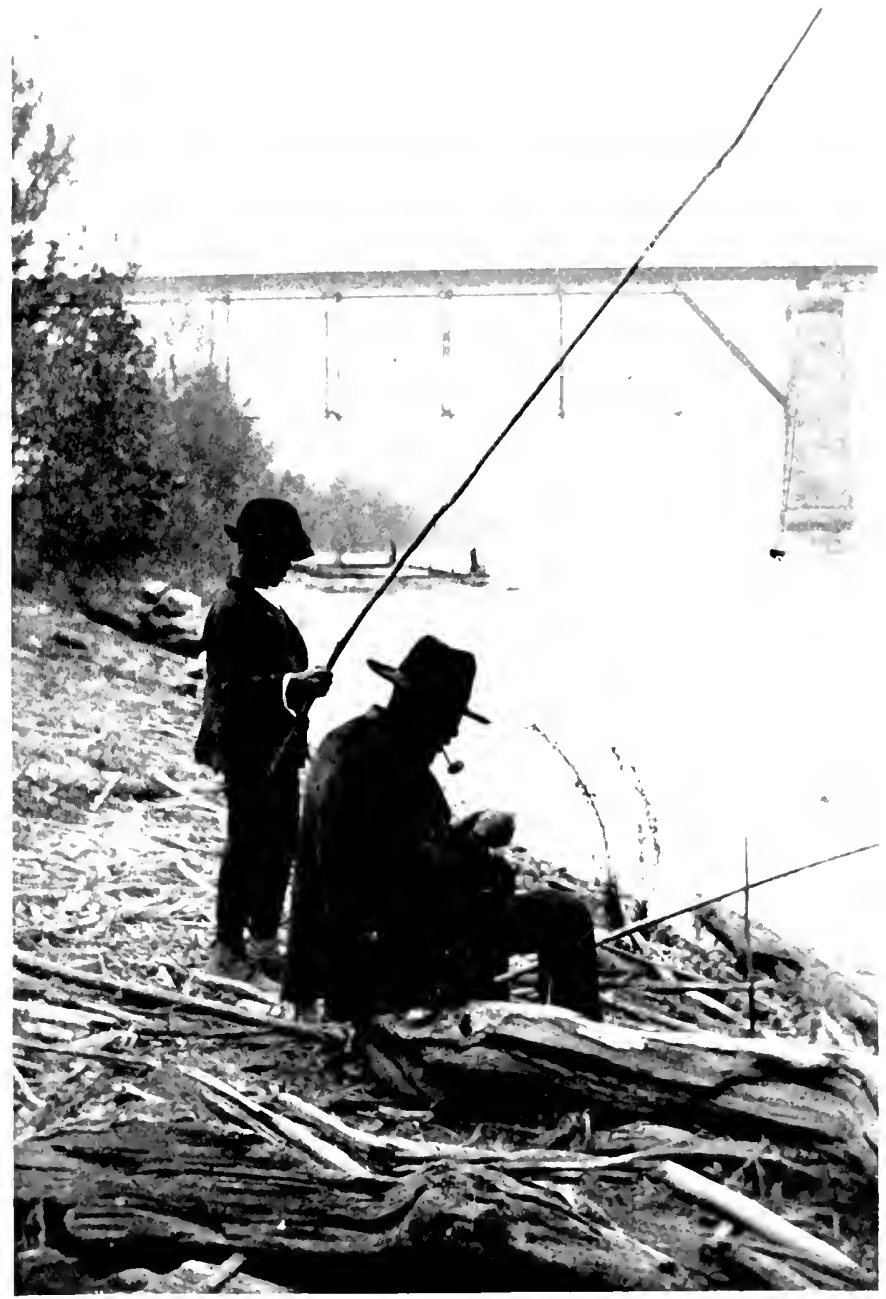

BuINe: THE Hoon 


\section{HIGHWAYS AND BYWAYS OF THE}

MISSISSIPPI VALLEY
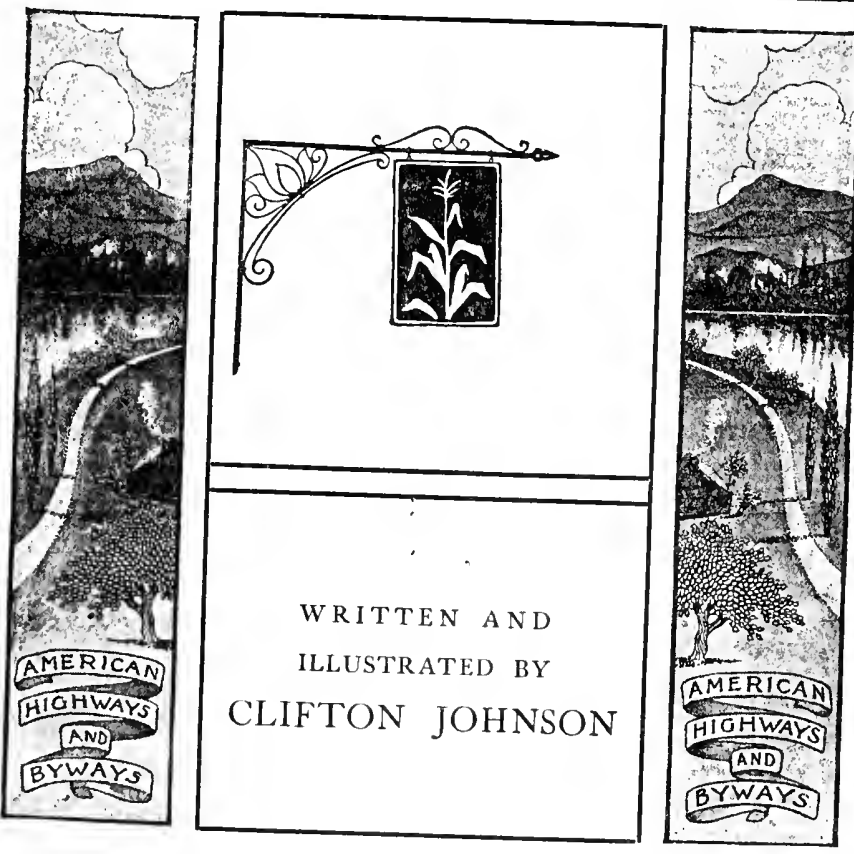

\section{Published by THE MACMILLAN COMPANY New rork MCMVI} LONDON : MACMILLAN AND CO,, LIMITED 
Copyright, soob.

by The Maimillan Company.

Set up and electrotyped.

Published October, 1906.

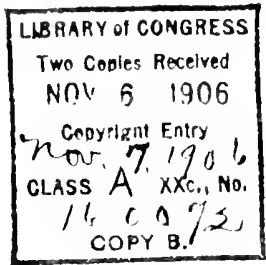

Most of the chapters in this volume were first published in The Outing Magazinte. Other portions have appeared in The Dilineator, in Good Houstkiping, and in 'The New England Magazille.

Electrotyped

and

Printed

at the

Noriood Press,

Noriwod, .14ass. 


\section{Contents}

CHAPTER

I. The City behind the Levee . . . . . I

II. Mosquitos and Alligators • • • • $\quad 18$

III. The Land of Rice and Sugar . • . • . 45

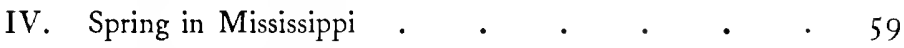

V. Cotton Patch Life in Tennessee . • . $\quad 84$

VI. Travelling in Arkansaw . . . . . 107

VII. Life in the Ozarks . . . • • . 124

VIII. At the Meeting of the Waters . . . . $\mathbf{I}_{4}^{8}$

IX. Mark Twain's Country . . . . . I60

$\mathrm{X}$. The Place of a Vanished City . . . 183

XI. Farm Life in Iowa . . . . . . $20 \mathrm{I}$

XII. On the Minnesota Prairies • • • • 215

XIII. New Times and Old in Wisconsin . . . . 230

XIV. Houseboat Life . . . . . . $25 \mathrm{I}$

XV. The Headwaters of the Great River . . . 266 



\section{Illustrations}

Baiting the Hook

- Frontispiece FACING PAGE

A Worker

One of the Old Narrow Streets .

Litcle Italians

On the Way to her First Communion . . . . 15

"Shooting Craps" . . . . . . . 18

The Captive . $\quad . \quad$. $\quad . \quad$. $\quad . \quad$. $\quad . \quad 22$

Dragging an Alligator from its Hole . . . . $\quad 27$

A Camp in the Swamps . $\quad . \quad \cdot \quad \cdot \quad \cdot \quad \cdot \quad \cdot 31$

A Shot at a Deer . . . . . . . . $3^{2}$

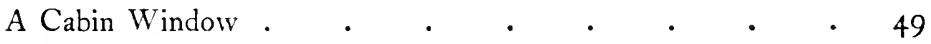

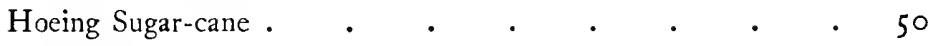

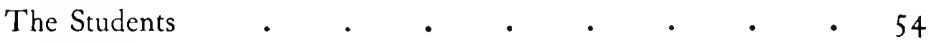

In the Heat of the Day . . . . . . 59

High Water • . . . . . . . . 63

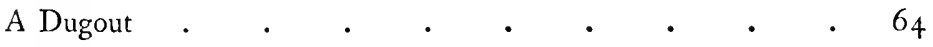

Beside the "Bayou" . . . . . . . . 68

A Landing at the Levee . $\quad . \quad$. $\quad . \quad$. 77

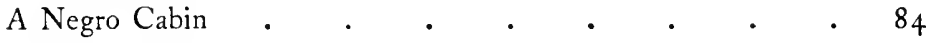

The Sitting Hen's Prison Coop . . . . 86

On the Porch . . . . . . . . 91

Explaining the Situation . . . . . . . $\quad 9^{6}$ 
FACING PAGE

Returning to Camp from the Village . . . . $\quad 107$

Work in the Woodland . . . . . . 113

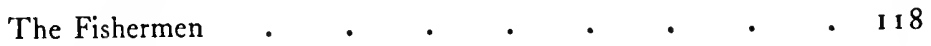

The Weather in the Almanac . . . . . $\quad 123$

Browsing in the Woods . . . . . . . 130

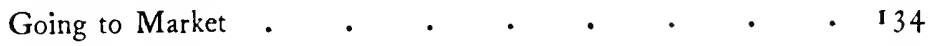

Travellers .

Beside the Kitchen Fire • • • • . • • 143

Making a Hen-coop . . . . . . 146

Prospects of a Blackbird Pie . . . . . . 148

In time of Flood . $\quad . \quad$. . . . . 157

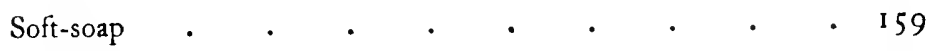

The Stepping-stones at the Ford . . . . 162

Mark Twain's Boyhood Home . . . . . . 166

A Game of Quoits • • • • • • • • • • • 17 I

Afternoon Comfort . $\quad . \quad$. $\quad . \quad . \quad . \quad 175$

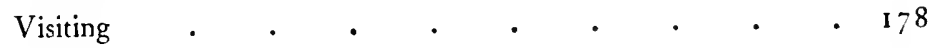

The Prophet's Well . . . . . . . 182

An Old Mormon Doorway . • • • • • • 187

A Garden Bonfire . . . . . . . • . I9I

Calking the Boat . $\quad . \quad$. $\quad . \quad$. 194

Making a Willow Whistle . . . . . . $\quad$ ı 96

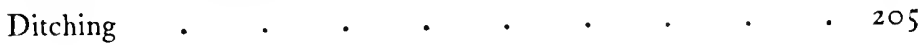

Churning at the Back Door . . . . . 207

A Notice on the Schoolhouse Door . . • . 208

Renewing a Town Walk. • . • • • • 212

The Fascination of the Stream . • • • • • 22 I 


\section{Illustrations}

$\mathrm{xi}$

FACING PAGE

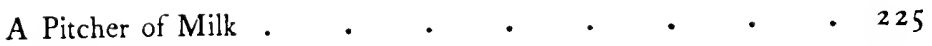

A Pause in the Day's Labor . . . . . . 226

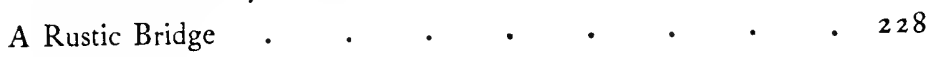

The Upper Mississippi • • • • • • • 237

At the Back Door . $\quad . \quad$. $\quad$. $\quad$. $\quad 239$

Making Lye for Soft-soap • • • • • $\quad 2^{2}$

Starting for Work . . . . . . . . 244

A House-boat Dog. $. \quad . \quad$. $\quad . \quad$. 253

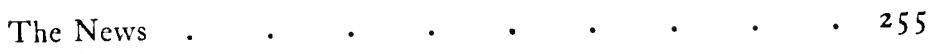

Fishermen . . . . . . . . . . 258

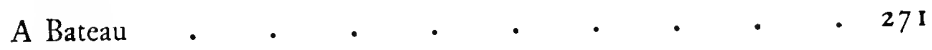

The Forest Fire . $\quad . \quad$ • $\quad$ • $\quad$ • 274

Floating Logs down the Mississippi near its Source • 281

The Frame of an Indian Wigwam • • • • • 287 


\section{Introductory Note}

LIKE its predecessors, this volume concerns itself especially with country life. To the traveller, no life is more interesting, and yet there is none with which it is so difficult to get into close and unconventional contact. Ordinarily, we get only casual glimpses. For this reason I have wandered much on country roads and lodged most of the time with the farm families or at the village hotels. In both text and pictures I have tried to show actual life and nature as I saw them in characteristic and interesting sections from one end to the other of the vast valley.

The volumes in this series are often consulted by persons who are planning pleasure tours. To make the books more helpful in this respect, I have appended to each chapter a note containing suggestions for intending travellers. With the aid of these notes, I think one can readily decide what regions one would like particularly to see, and know how to see such regions with the most comfort and facility.

Hadiey, Mass.

Chifton Johnson. 



\title{
Highways and Byways of the Mississippi Valley
}

\author{
I
}

THE CITY BEHIND THE LEVEE

HE country in and about New Orleans, if it
was in a state of nature, would be mostly
marshland. When it was first settled, the cabins of the future metropolis stood among weeds and willows and rank swamp growths, and the hamlet was infested with mosquitoes, snakes, frogs, and alligators. Every time the Mississippi was in flood, the water came creeping over the land, and it was not long before the inhabitants began to bank out the ravaging river and attempt to drain away the surplus moisture of the soil. As the city grew, the levee was extended and strengthened, and that great earthen rampart along the water front is to-day the community's chief dependence for health and for protection against the vast destruction that would be wrought by the constantly recurring floods. Whenever the water is up, the city lies lower than the river level, and if the stream gets so high that it threatens to wash over the crest of the embankment, 
2 Highways and Byways of the Mississippi Valley

there is intense excitement, and hasty bulwarks of sandbags are piled on top of the levee where the danger is most serious.

The situation is strange and dramatic. It stirs the imagination and arouses the interest, and when one thinks of New Orleans, the Mississippi and the stout wall of earth flanking it seem the most vital features of the place. My impulse, therefore, was to seek the river front as soon as I arrived in the city. There I had my first sight of the giant stream of our continent - and what a sullen, murky, threatening torrent it was! The banks were nearly brimming full, for I had come in early April, and the flood season is ordinarily included in that month and the one following.

The water was a dull yellow color and looked like liquid mud. I was surprised to see people drinking the dubious fluid, and I learned that the riverside workers and loiterers had a real relish for it. Some would kneel at the water's edge and dip it up with their hands for a hasty gulp; but most depended on tin receptacles which were to be found here and there on the wharves, and which had usually done service for holding canned goods. Each had a string attached, so that you could let it down and fill it while standing on the wharf. I was curious to know how that thick and soupy liquid tasted, and I picked up one of the cans and lowered it into the water.

A man was sitting near with a line in his hand, trying 


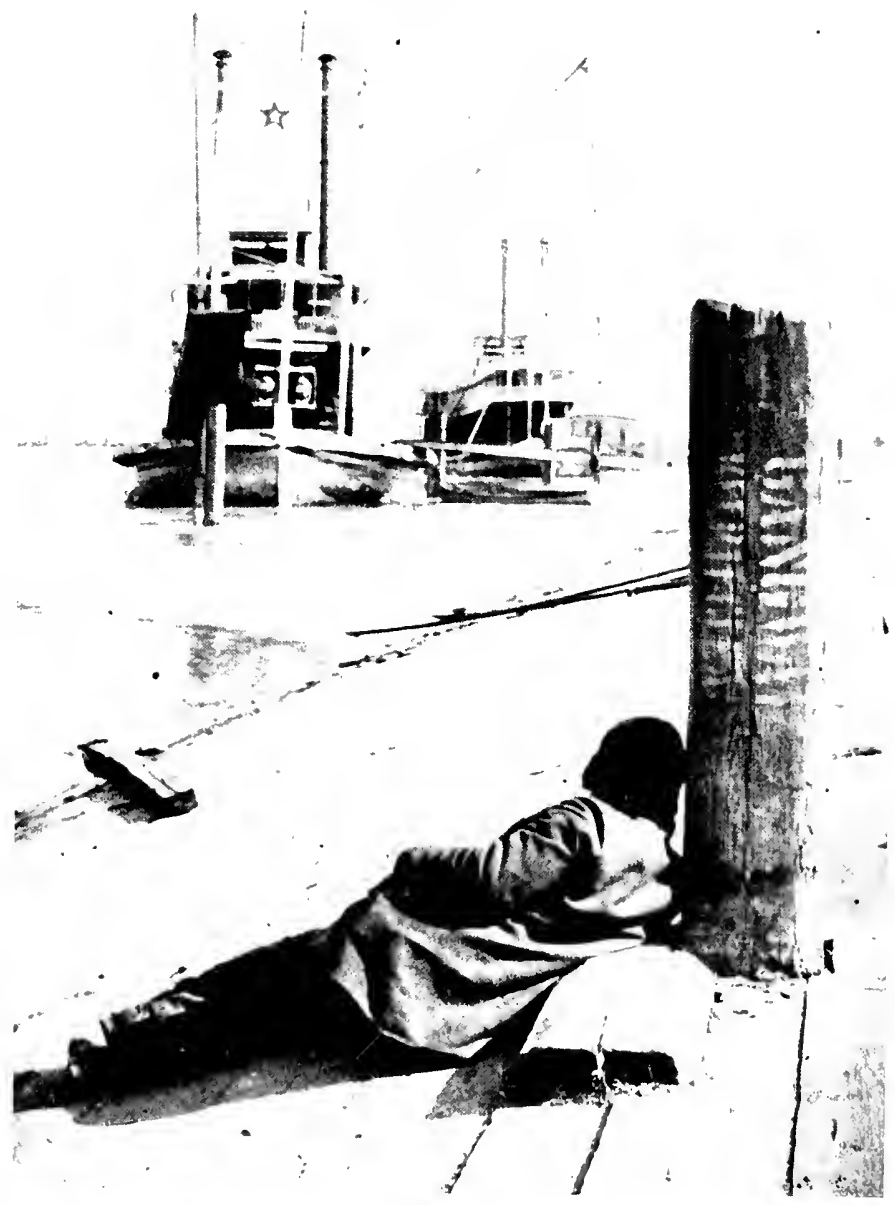

A WORKER 

to entice some fish from the roily depths. He noted what I was doing, and saw that I was a green hand, and when I began drawing up my cup he advised me to empty it and try again. "You got that water right at the surface where it ain't clean," he said. "Dip down deep."

I did as he bid, and, after all, the water was not bad. It was palatable enough in spite of its earthy flavor and slight hint of grittiness.

The river was streaked and strewn with scurrying rubbish, and wherever along the shore there was an obstruction the floating trash caught in masses. A good many men and boys were securing such of it as might serve for firewood and were piling it on the wharves. Most of them caught it with their hands or with poles and ropes, but occasionally a boat was used. One fellow who seemed to be doing especially well had a spike-pole with a cord attached, and when a stick was a little too far out to reach in the ordinary way he threw the pole like a harpoon.

I had an impression I could see all of New Orleans' shipping in an afternoon's ramble, and I kept on along the river northward until I became dismayed at the endless swcep of the wharves. The city is one of the chief commercial gateways of our continent, and the wharves line the stream for a distance of twelve miles. They accommodate the local craft, the river boats, and a great fleet of ocean vessels from the world over. The 
4 Highways and Byways of the Mississippi Valley

river itself seems dwarfed when the monster steamers of the ocean plough through its dun waters. Perhaps the most interesting boats at the wharves are the Mississippi packets - white, swan-like, with towering smokestacks, and a long gang-plank suspended in mid-air at the prow. Then there is an odd medley of ferry-boats, tugs, titanic dredges clawing up the mud from the river bottom, luggers with their curious lanteen sails, and fruit vessels from the West Indies, Mexico, and South America. The flow of produce in and out never ceases.

Some classes of goods go at once into the warehouses, trains, or vessels, but others are stacked for a longer or shorter time on the wharves. There are vast quantities of great, clumsy cotton bales, rows of oozy molasses barrels, heaps of raw sugar in coarse brown bags, piles of lumber, great odorous hogsheads of tobacco, and boxes and crates and bales of a thousand shapes and a thousand variations of contents. But cotton is more predominant than anything else; for New Orleans is the greatest cotton port in the world, and the storing, selling, and handling this product furnishes a livelihood to the majority of the city's three hundred thousand inhabitants.

The wharves are a working-place, and they are likewise a loafing-place. The hobbling elders and the boys resort thither to spend their leisure and feel the throb of life and watch the work and the river. The sightseer from a distance is there to witness the activity, and 
the laborer out of a job who is more or less desirous of finding another is drawn there also. If he finds work he becomes a part of the busy turmoil, and if he does not find work he drifts about as chance and momentary fancy may direct. Possibly he takes a nap. The colored man on a warm day can stretch out or double up almost anywhere and sleep interminably.

The wharves are not without their compensations to the loafers. There is always something new and interesting going on, and stray eatables are often to be had perfectly free, especially if fruit steamers are unloading. For instance, when a banana vessel discharges its cargo, you will see the stevedores in half a dozen lines, each man with a bunch of fruit on his shoulder carrying it from the vessel to the refrigerator cars. Many bananas get broken off, and others that are overripe are pulled off the bunches purposely. Every worker treasures up a few of the best to carry home, and the remainder of the pickings are thrown aside. Hovering around the edge of the workers is a throng of men and boys watching for a chance to secure a share of the discarded bananas, and all of these human buzzards get their hands full of really excellent fruit. Some of the waste fruit is thrown into the water, and close under the steamer's hull you will perhaps see a rowboat with a couple of boys in it, one at the oars, and his companion capturing the floating plunder with a scoop-net. 


\section{Highways and Byways of the Mississippi Valley}

Another dainty easily to be had by everybody is sugar. Raw sugar in bags comes from Cuba in vast quantities, and as the sacks lie on the wharf a man with a gouge digs into the side of each for a sample. Any one who chooses can then thrust in his fingers and sample the contents on his own account, and many take advantage of the opportunity.

New Orleans' chief thoroughfare is Canal Street, a broad, modern business street that divides the old town from the new - the foreign city from the American. The latter is comparatively uninteresting, but on the other side of the dividing line the manners and customs of France prevail. French is the principal language and the streets bear French names. The people keep to themselves, and some of them are said never to have crossed Canal Street. Indeed, this district is probably more foreign in aspect and life than any other that could be encountered in the United States. Such narrow streets, such queer, balconied houses, such strange little shops, grimy and dark, and so many people of alien features who do not understand English, or who speak it with an unfamiliar accent!

The population is dense, and you see frequent doors where passages lead to dwellings behind those fronting on the streets. Every house has its courtyard, and this is usually paved, and has flowers, vines, shrubs, and possibly tall trees growing in it. One article never absent is a cistern, a great, high, hooped affair that will hold 


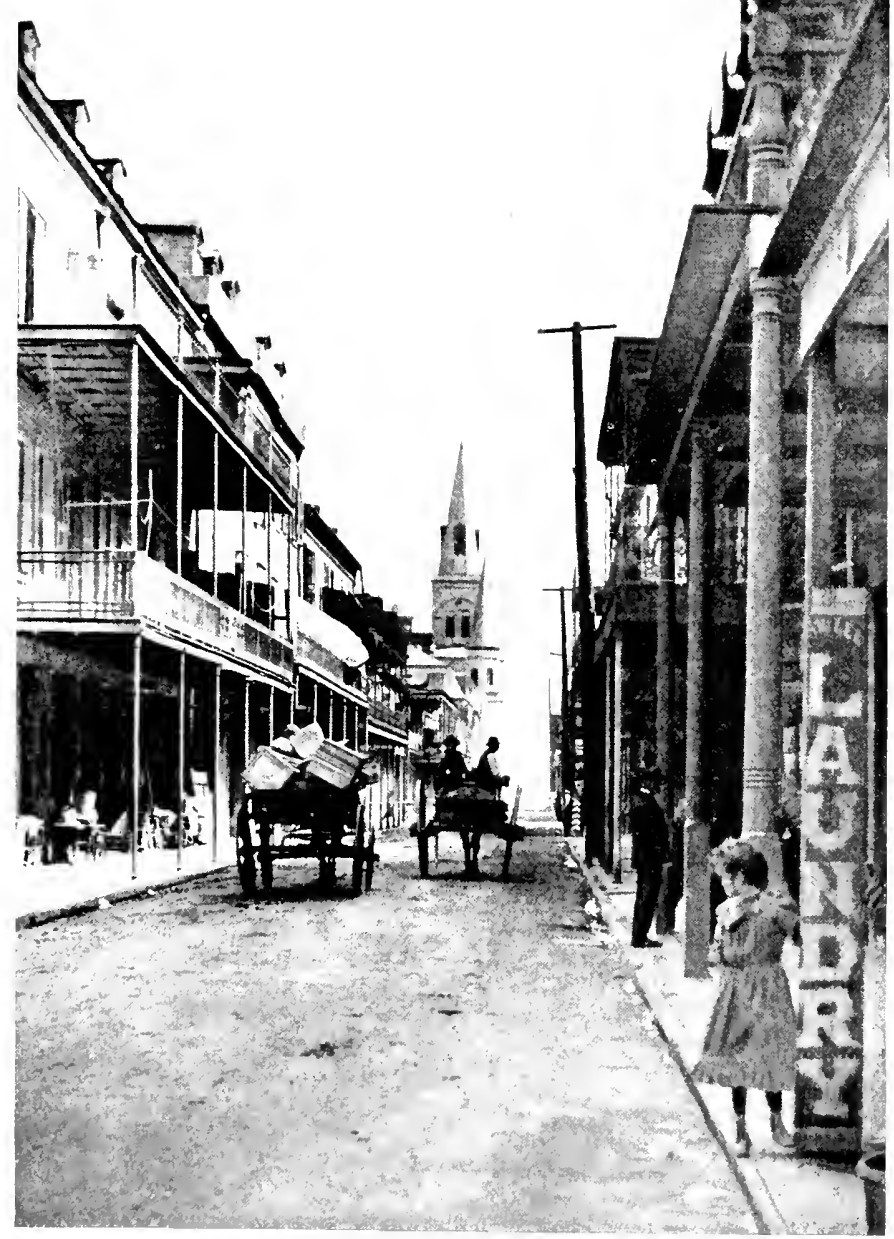

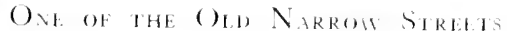


several hogsheads. Into it flows the rain-water from the roofs. This water is used for all sorts of household purposes, - even drinking; but it tastes of roofs and receptacle, and most people prefer Mississippi water when they can get it. The better class of families have river water piped into their houses from the city waterworks and filter it for drinking. Others get water in barrels or bottles from springs a few score miles out in the country.

The courtyard is the children's playground. There their elders loiter, and there the washerwoman does her scrubbing and hangs out the clothes. The buildings around are balconied, and the whole space is a convenient gathering-place for rubbish, and never lacks picturesqueness. Often fig trees flourish and ripen their fruit in it, and sometimes it contains lofty magnolias queenly trees that all summer open their large, white, fragrant blossoms amid the glossy foliage.

Some of the city buildings date back over a century to Spanish times, and their quaint and massive architecture and weatherstained, battered walls have a charm all their own. One of the most imposing mansions belonging to a slightly later period is a large, square structure, erected by an admirer of Napoleon at the time of that noted leader's adversity. The emperor was urged to come to New Orleans and accept the mansion for his residence, but he did not see fit to take advantage of the generous offer. 


\section{Highways and Byways of the Mississippi Valley}

Another large building is known as "the haunted house," and every local inhabitant can tell strange legends concerning it. In the days long before the war, it was the home of an ogress-like French madame. "She had much money," said a woman who told me its story; "and she would buy slaves just to torture them. She would hang them up in the garret by their thumbs and whip them. The slave babies she would throw into the cistern, and after she was gone they found that cistern full of the babies she'd drowned. Many a mean thing was done in slavery times, but that was the worstest I've ever heard; and yet slavery was well enough in most families. Those niggers we had them times reely had to have a boss over them. They were not'ing but animals - and so wild they had to be tamed. They were ugly-lookin', too - like apes, with big thick lips and flat noses, and hair that kinky you couldn't get a comb in it. We don't have such niggers any more; but I was tellin' you about that French woman. There were gardens around the house then, and the street was not built up solid as it is now; and, besides, the stone walls of the house were very thick. So nobody heard the cryin' and hollerin' of the slaves. But in the end she was found out, though she was slick enough to see there was goin' to be trouble, and she ran away to France.

"After that the house was empty and people began to see lights in the windows at night, and when they 
listened at the doors they would hear the cries of the dead slaves. For a long time it stayed closed up and then a high school was started in it; but the children saw ghost people going through the rooms and heard sounds that scared them, and they would jump up and run out screaming and yelling. They just couldn't stay there, and the school had to stop. The building was no use to nobody and couldn't be sold or rented till many years passed, and then a Dago who didn't believe in haunts bought it for very much less than it was worth. He's got people livin' in it, and has a saloon on the ground floor, and he charges a nickel admission to see the building inside. Some say they still hear queer things there; but others do not hear not'ing strange at all."

It is quite evident to the wanderer in the Creole quarter that the days of glory for this part of the city are of the past. Business and fashion have moved on and left the district stranded on the shores of time, though its decay and tendency to dilapidation doubtless make it more moving to the imagination than it was in its heyday of prosperity.

"Oh, things was very different here before the war," explained the woman who told me about the haunted house. "The old French part that you now see so shabby was very fine then. Everybody was rich. You could pick up the money by the barrelful. The white people didn't need to do any work. They all 
IO Highways and Byways of the Mississippi Valley

had servants. Some of 'em wouldn't even put on their own shoes when they got up in the morning, but had a slave do it. Then the war came and knocked us all down. Everybody lost - lost money, lost property, lost slaves. The change was hardest of all on the Creoles. They had too much pride to work - yes, they would starve rather than work, and so this old part of the city has been poor ever since."

A peculiar characteristic of the city is that family food supplies are largely obtained from markets where many tradesmen congregate in a single great shed-like building. The smaller markets are only open in the morning and later are deserted to myriads of flies and doubtful odors. The early hours of the day are the marketing hours, and much of the buying is done before breakfast; but in the neighborhood of the great French market, near the cathedral and the wharves, there is a coming and going of basket-laden, sunbonneted women all day. A series of widespreading roofs mounted on iron or masonry pillars here shelter a dim and cavernous interior, where you find a wonderful array of fruit, vegetables, turtles, tropical fish - plunder of every variety both of land and sea and from far and near.

The New Orleans streets are in a few instances paved with asphalt, but most are laid with big square slabs of granite, which time and travel have canted at all sorts of angles and worn and battered into all sorts of roughnesses. Over these stones the traffic jolts and 



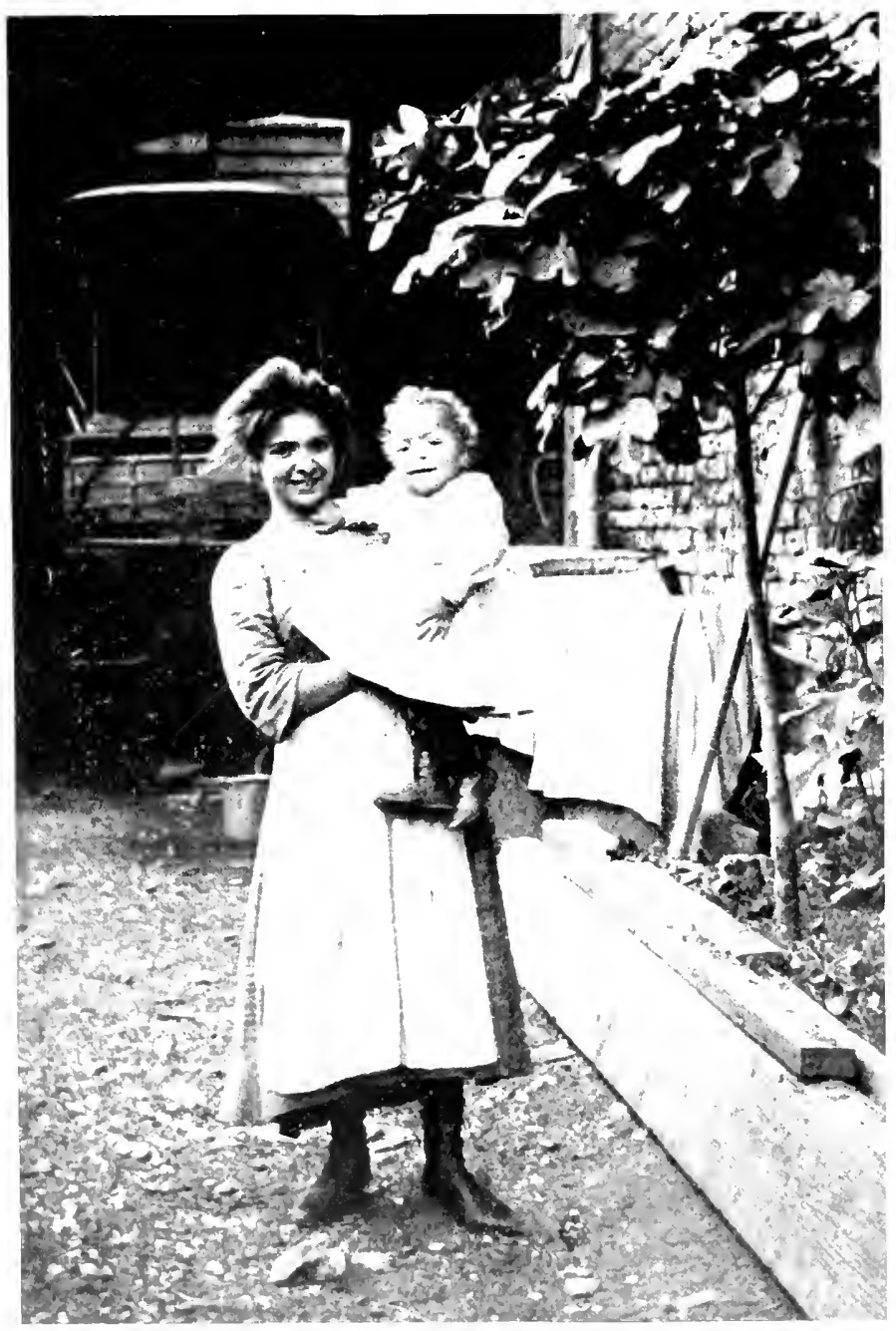

$1,1111+1101,111$ 
rattles, and when a loaded cart approaches with any speed there is such a crash of impending doom as makes the unaccustomed stranger jump with alarm.

Owing to the low, marshy situation of the town, an underground drainage system presents exceptional difficulties, and in the old city the street gutters serve as sewers and likewise as a dumping-place for garbage. They are encumbered by refuse through which flows a filthy, sluggish rivulet, and I have never encountered dirtier and more ill-smelling thoroughfares. A recent report of the superintendent of streets lists some of the gutter trash as "plank, bags, wads of paper, straw, wire, decayed vegetables, kettles, cans, boxes, banana stems, cast-off furniture, dead puppies and rats."

The gutters of the city slope away from the river to canals, from which the water is pumped into channels connecting with Lake Pontchartrain, five or six miles distant. The lake is a broad inreach from the Gulf of Mexico, and is several feet lower than the river.

The same cause that results in surface drainage accounts for the habit of making burials in tombs above ground instead of in the watery soil. The cemeteries are heavily walled about and thickset with the brick or marble dwellings of the dead. These tombs usually consist of two vaults well cemented to prevent exhalations from interred bodies; but sometimes the vaults are built in a solid mass in tiers and are then called ovens. Rigorous laws are enforced to prevent vaults 
I Highways and Byways of the Mississippi Valley

being opened until a year or two has passed after a burial. Then, if a vault is needed for another body, it is unsealed, the coffin within is broken up and burned, and the bones are deposited in a space left for the purpose at the base of the tomb. Thus many burials can be made in the same vault.

One cemetery that attracts a particularly numerous concourse of visitors has a tall stone chapel in it dedicated to St. Roch. Here miracles are wiought which have made the place famous. According to a little pinkcovered pamphlet sold at the cemetery, St. Roch is one of the greatest saints of France. He was born in 1294, marked with a small red cross in the region of his heart. This singular mark was considered by his parents to foretell his future holiness, and he early "astonished every one by the pious and charitable instincts of his gifted soul."

At the age of fifteen his parents died, and he became the heir of "their vast wealth." He was too young to have entire control of this property, but he promptly gave away as much of it as was at his disposal. Then he put on the garb of a pilgrim and started for Rome. On the way he came to a city where the plague was raging. That "inflamed his charitable zeal," and he began nursing the sick. "God rewarded his noble sacrifice," and in a short time the plague disappeared. Then he plodded to another city similarly afflicted, and "delivered it from the ravages of the plague." 
Everywhere he went the result was the same. Contagion fled before him, and it began to be whispered about that he was an angel in disguise. Many he restored to health by simply making the sign of the cross over them. For years he continued his labors among the Italian cities, but at last he himself fell a victim to the epidemic and crept away to a cave in the forest. After closing the entrance with brush he knelt to pray, when a fountain of sparkling water burst forth right before him. He quenched his thirst and washed and was much refreshed. Such was the power of the water that he presently entirely recovered. Then he returned to his early home in France. But he was not recognized, and "his sole ambition being to endure humiliations for the love of Christ," he would not tell who he was.

That put him under suspicion, and he was arrested as a vagabond of doubtful character and thrust into prison. For five years he continued in the prison "communing with God and practising the severest austerities, his only food bread and water, and even that used abstemiously." Death came to his relief at the age of thirty-four, and when the jailer found him lifeless on his dungeon floor the apartment was filled with a mysterious light, and near the body lay a marble tablet with the following inscription on it in letters of gold: "Thou who, being attacked by the plague, will have recourse to the powerful protection of Blessed Roch, beloved by God, shall find immediate relief." 
14 Highways and Byways of the Mississippi Valley

The mark of a cross was found on the dead man's breast, and then it was known that he was St. Roch. The next year his native city built a chapel in his honor, and since, in other sections of France and in other countries of Europe, temples, chapels, altars, and statues of St. Roch have multiplied. Nearly all these originated in a sense of gratitude for protection he had granted in periods of public distress to the communities which have erected them.

The New Orleans chapel was dedicated to St. Roch at the time of the city's yellow fever epidemic in 1878 , and the municipality continued remarkably free from devastation by contagious diseases until the city was again invaded by yellow fever in 1905. The little Gothic chapel is now popularly known as a wishing shrine. Thither people come to pray for whatever they happen to desire, confident that they have a much better chance of having their wishes granted than if they offered their petitions elsewhere. A considerable proportion of its patrons are young women who beg the good saint to send them husbands.

In the dim, cool interior, when I was there, several yellow candles were burning before the altar - votive offerings of visitors. The walls were hung with small tablets bearing the word Merci, and with crutches left by the lame and halt who have been healed at this miraculous spot, and with casts of hands, feet, legs, etc., presented by persons cured in this member or that. 



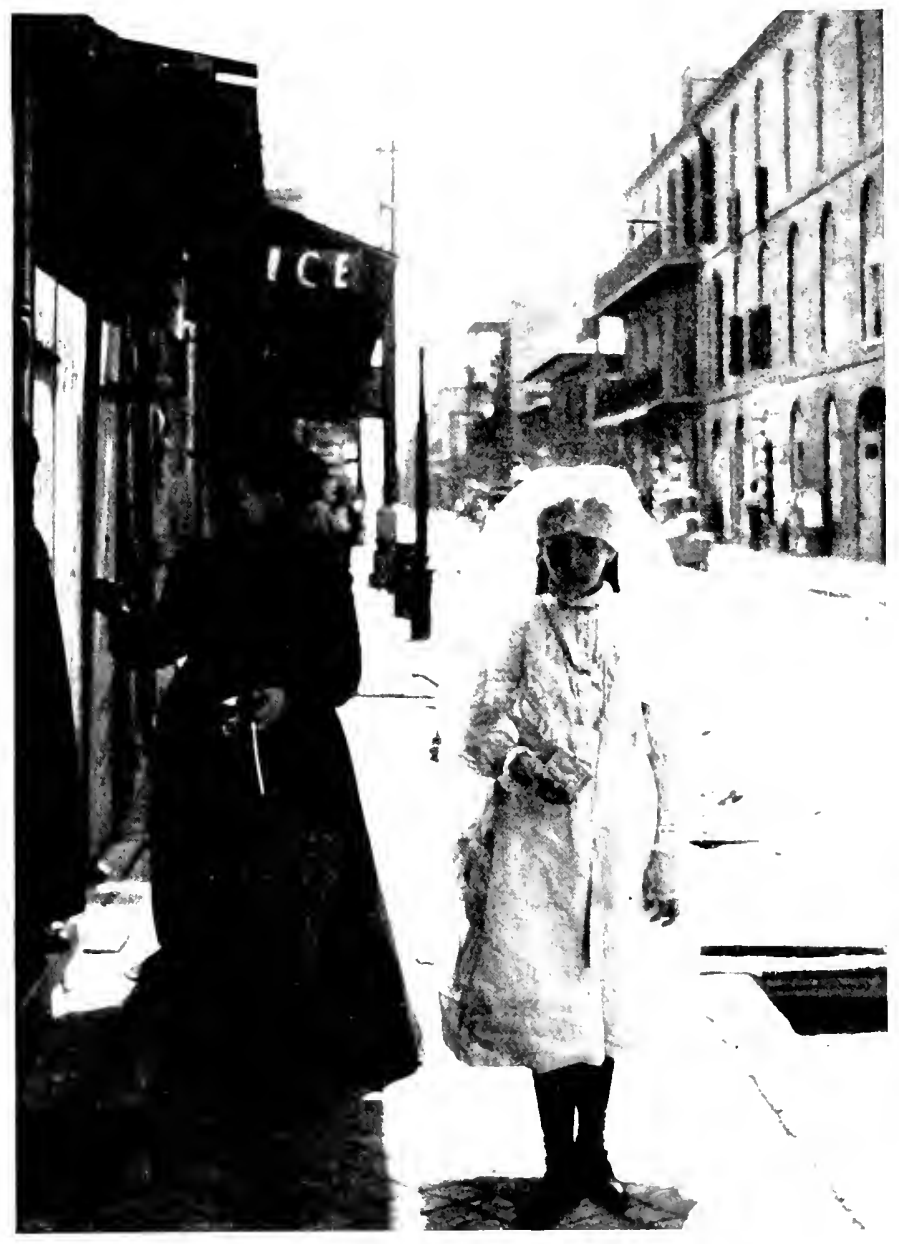

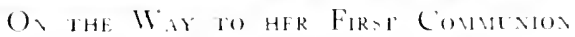


Yet not all requests are granted, and many who come hopeful go away with sad disappointments and heartaches. Thus, one person told me about a cripple boy whose spine had been hurt when he was a baby. "He was all shakified," the narrator continued, "and he couldn't walk well, and he speak so bad you couldn't hardly tell what he said. They took him to St. Roch Cemetery, and soon as he was inside the gate he didn't walk lame any more, but began to run to the chapel; and they were scared to see him do like that. I suppose the angel was acting on him; but it give his folks such a funny feeling that they took him away and wouldn't go again. Perhaps, if they had kept on going he might be well now instead of a poor little cripple. But you can't tell. I know lots who have visited St. Roch's Chapel and had more trouble afterward than they did before."

Of points of interest in the city environs I was most attracted by the battle-field a half dozen miles down the river, where Andrew Jackson won his famous fight with the British. The latter part of the way I walked along the crest of the levee. On one side was the muddy torrent of the Mississippi almost washing the top of the embankment. On the other side, ten or fifteen feet below the river level, were mansions and cabins amid fields luscious with tall grasses and odorous with clover blossoms. The trees were fullfoliaged, all the early vegetables were ready for market, 
I6 Highways and Byways of the Mississippi Valley

innumerable birds were singing, and the roads were thick-covered with a powdery dust.

I found the battle-field amid broad, level pasturelands, and essentially unchanged since I 8 I5. Here Jackson, with about six thousand men, threw up entrenchments between the river and a swamp, and awaited the assault of Pakenham's veterans, who outnumbered the defendants two to one. The battle lasted less than thirty minutes; yet in that time the attacking force lost twenty-six hundred men, while the Americans had only eight killed and thirteen wounded. Never in all history was an English army so badly defeated.

Portions of the old earthwork behind which the Americans fought still remain, and in the wide hollow of the ditch, from which the earth was excavated, are pools and stretches of stagnant water, the home of mud-turtles and frogs, the breeding-place of mosquitoes, and the hunting-ground of darning-needles. I combated the mosquitoes as long as I lingered, but they were persistent in spite of serious losses, and I presently retreated to the city.

$I$ arrived in the early afternoon. It was a typical day - the air clear, the sunshine burning. I was never much inclined to stir about in the noontide hours, and, like every one else, if I chanced to be on the streets at that time I kept to the shady side. Shade was at a premium, and as much of it was secured as possible by 
balconies on the house fronts and roofed sidewalks before the stores; and when the sunlight slanted beneath these roofs, curtains were drawn down from under the eaves to shut out the glare and the heat. Yet while it was so sweltering in New Orleans, the papers told of blizzards, frosts, and snow in the North. What a land of contrasts!

Note. - New Orleans possesses many attractions for the tourist, and one can stay an indefinite length of time without exhausting its interest. I have spoken only of salient features that I myself enjoyed most, but there is much else that has a strong appeal to the stranger. Get a guidebook at a news stand, and you will find in it all the detailed information necessary to enable you to decide what you wish to see. As a rule, the points of interest are quite accessible, most of them by trolley, and the expense of sightseeing need be but small. It is advisable, however, if one would be comfortable, to go only to the best hotels and restaurants. Among the various river trips that can be made, perhaps the most attractive is an excursion down to where the river joins the gulf. 


\section{II}

MOSQUITOES AND ALLIGATORS

$\mathrm{N}$ the delta country of the lower Mississippi,
swamplands are everywhere predominant, and
the watersoaked marshes alternate endlessly with ponds, lakes, and sluggish streams. It is a region not easily brought under subjection by man, and though the sawmills and the fires sweep off the forests, the country they leave behind is almost as lonely and lacking in human inhabitants as before. There the creatures of the wilderness make their homes, and one would have to go far to find any district that presents so many advantages for their safety. Yet they are not left in peace, for no difficulties can wholly daunt the hunters and the native trappers.

To get a first-hand view of conditions in the swamp country, I made several visits to a little place a few miles out of New Orleans. My acquaintance with it began on a Sunday. There is always an exodus from the city on pleasant Sabbaths, and the train on which I went was crowded. Everybody seemed to be starting on a picnic-old and young, singly, in friendly groups, and in family parties - and they were all well laden with 


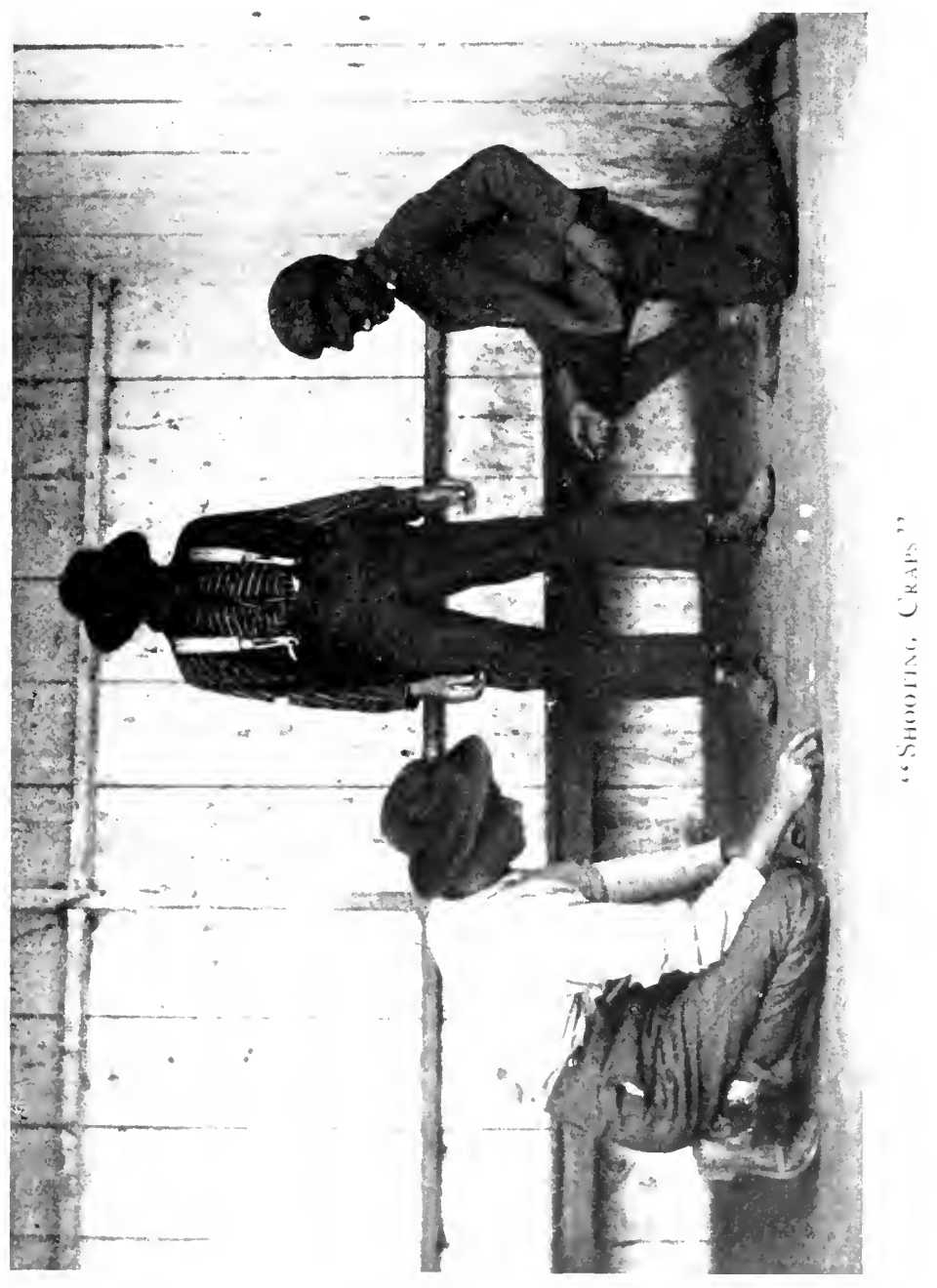


, 
baskets and boxes of food, and with guns or nets and fishpoles. Many got off at each station, and when I, too, left the train, it was with the usual crowd. The hunters and the fishermen lost no time in dispersing to their favorite haunts and I was left alone.

Four or five cabin homes and meagre garden patches were within sight, and the rest was ragged forest and reedy marshes. It was all so forlorn that I wished myself back in the city, but there was no train till toward night. I sat down in the rude little shed that served for a station to consider, and a few score of mosquitoes promptly began to investigate me and take some sample bites.

Pretty soon two young white fellows and a colored boy came loafing along to the station and started a game of "craps." One of the whites played against the colored boy, and the third fellow looked on. The players knelt on the platform opposite each other, and the game continued until the unlucky colored boy had lost all his money, five or ten cents at a bet. The game was played with two dice, which each player would in turn shake in his hand and then give a little throw along the planking. Every throw was accompanied by a half-articulate exclamation and a snap of the fingers. The thrower lost or won according to the number of dots that turned up on the dice.

All around the station grew weeds, grass, and low shrubs, except for an acre or so that had been cleared 
and was used for stacking moss. This moss draped the forest everywhere with its gray, pendent masses, and the gathering of it was the principal industry in this particular region. When prepared for market it makes a very good substitute for horsehair to put in mattresses and in sof as and other upholstering. Sometimes the gatherers go in a boat and pull the moss from the trees beside the waterways. Others pick it off fallen trees or from the ground, where it has been strewn by the winds. However, the commonest method is to resort to the forest, put on climbing spurs, and go up in the trees to gather it. Two hundred pounds is a fair yield for a tree, but some of the big oaks have half a ton or more on them. A good worker will easily secure five hundred pounds in a day, for which he will be paid two dollars.

The main substance of the moss is like a coarse leathery thread, but this is encumbered with a fuzzy outer covering and numerous narrow leaflets which must be gotten rid of, and the stems are full of sap. Those who gather moss in a small way soak it in some swamp hole to remove the leaves and cuticle and then hang it on a fence to dry. But in the clearing adjoining the station it was heaped in great square flat piles fully fifteen feet across and three feet high. The piles were kept thoroughly wet down for about a month, and afterward the moss was dried on some wire fencing erected for the purpose. Lastly it was baled and shipped. 
These details were imparted to me by a tall leanvisaged man named Dakin. I had gone from the station to look at the moss piles and found Dakin sitting on the edge of one of the heaps smoking his pipe. $\mathrm{He}$ was the chief citizen of the region - the agent of a vast estate covering twelve square miles which was owned by some one over in France. Formerly a part of the estate had been cultivated as a sugar plantation, and this was populous with slaves and quite thriving, but since the war no crops had been raised and the old fields have degenerated into their original wild jungle and morass. There are hardly a score of families on the whole tract now, and it only returns about enough income to pay the taxes.

The rental for each of the families who live on it is twenty-five dollars a year. That sum gives a cabin home, a garden patch, and the privilege of free firewood, and of fishing, trapping, picking moss, etc. If a household comes to the estate and builds its own cabin no rent is charged for the first year. The value of the house is thus appraised at twenty-five dollars. Really, the frail little shanties that serve for dwellings are worth no more, and the home of the agent of the estate was not much better than the others. It was not far away, across a marsh-bordered bayou, which was spanned by a long causeway of oak slabs and discarded railroad ties.

Dakin invited me to go to the house with him. To get there was rather a delicate matter, for parts of the 
22 Highways and Byways of the Mississippi Valley

causeway were missing and other parts dislocated, as the result of a flood two years before. My companion had some thoughts of repairing it; but he said it served well enough to cross on foot, and he seldom needed to use it for animals or vehicles. When he did there was another bridge three miles distant that served instead.

The bayou was rather impressive from the middle of the bridge. It was an almost stagnant waterway, with many giant, half-dead trees on its shores reaching aloft their gaunt, moss-draped limbs. Along its margin were frequent fallen trunks, and a green scum covered much of the surface. The water itself was dark and full of tadpoles. I could hear a bullfrog's deep, resonant voice at intervals from near by. I could see mudturtles sunning on the snags that rose above the level of the water, and in spots there were water-lilies angels of the swamp - chaste and beautiful amid their sinister and noisome surroundings.

Dakin's house stood on slightly rising ground. It was an unshaded, irregular, one-story structure made of a single thickness of unplaned boards. Cracks were numerous and none of the three rooms had ceilings. The furniture was of the harum-scarum order and not abundant at that. The hens walked familiarly in and out, and several hounds and bird dogs were loafing a round.

"You have cats, too?" I suggested.

"Yes," replied Mr. Dakin, "sometimes we have a 


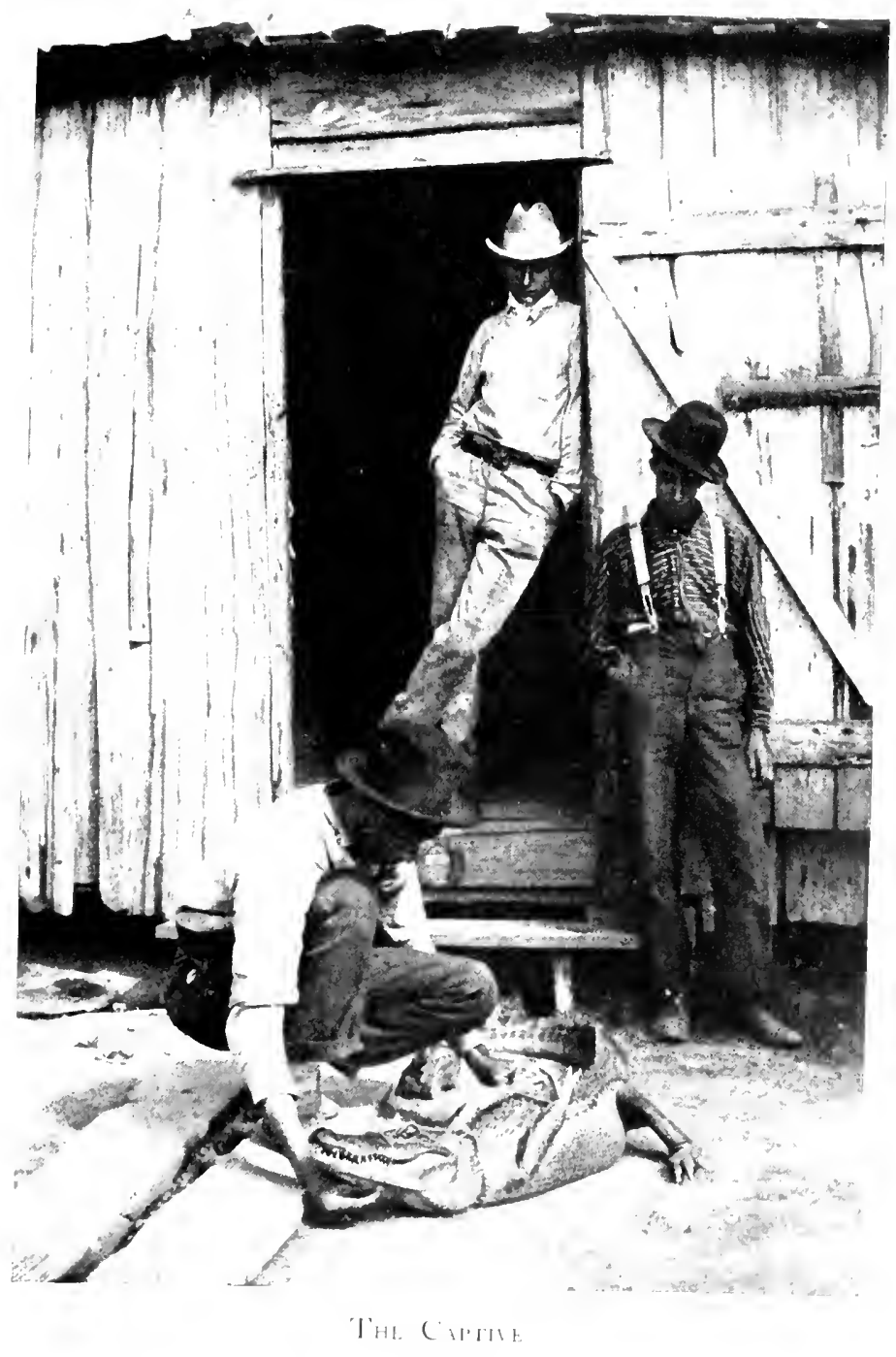




$$
\text { ? }
$$


dozen, and again not any. Depends on what kind of a humor I get in. They ain't much good for contendin' with such rats as we have hyar. Why, some of our rats are as big as raccoons and'll weigh ten pounds. We've got rats right in this house that have been hyar seven years. They make more noise nights movin' aroun' than a man. I bought a steel trap once and tried to ketch 'em; but I never got only one. After that they knew too much."

We had sat down on the piazza, or "gallery," as it is called in the lower Mississippi valley. I had to adjust myself with care, partly because my chair was rickety, partly because the floor boards were loose and much worn and broken. Moreover, one of the little girls of the family approached every little while to have a silent look at me, and she would step on the warped-up ends of the boards that ran under my chair and joggle me in a way that was quite discomposing.

"I been a-threatening to build over this hyar floor," remarked Mr. Dakin; "but it skeers me the price they done been puttin' on lumber. If lumber keeps gettin' mo' expensive the nex' ten years the way it been a-doin' the las' ten, a poor man like me won't be able to buy no boards, even to save himself from bein' hung. We'll have to live in dirt houses."

Right before the main door to the dwelling was a yawning hole in the gallery floor nearly a foot across. It was perfectly round and had charred edges. I noticed 
24 Highways and Byways of the Mississippi Valley

that every time Mr. Dakin finished speaking he would spit into the floor hole, and he did this with a precision that reflected great credit on his markmanship. It was a new kind of a spittoon to me, and I asked how the hole came there.

"Well, I'll tell you," said Mr. Dakin, ejecting a spirt of saliva through the subject of his remarks. "We fixed up a mosquito smudge in a tin pail one evenin' and set it there front o' the door, and the fire burned through the bottom o' the pail and through the floor, too. We discovered what was goin' on jus' in time to save the whole house from burnin' up."

One of the crap players I had seen at the station had joined us and lounged down on a bench that was on the gallery. "This' $d$ be the fines' country thar is if 'twa'n't for the mosquitoes," he affirmed; "but thar'd be so many people flock in hyar they'd spoil the huntin' an' fishin',"

"Yes, Jake, you done spoke the truth for once," said Mr. Dakin. "There'd be a man to every fish, if mosquitoes wa'n't so bad. Why," he added, turning to me, "we have mosquitoes hyar all the year round. Even in winter, when hit's freezin' outside, you c'n build up a good hot fire in the house and they'll come out from somewhar and bite you."

"I've known it to snow," said Jake, "and then jus' let the sun shine half a day, to melt it off, and the mosquitoes'd eat you up. They're worst though in 
August when the weather is hottest. You can't work without gloves, then, and you got to put your coat on and tie up your head and years."

"Did you ever notice how swift they can fly?" asked Mr. Dakin. “They c'n go faster'n a railway train. I've sat in the cyars with the winder open and seen a mosquito racin' with the train and tryin' his darndest to git me; and he'd gain a little and a little mo', and then in he'd come right on to my hands or face."

"One thing I don't understand is why they bite night and day both," observed Jake. "Hit seem like they had ought to rest one time or the other."

"A rag smoke'll make 'em hop," said Mr. Dakin. "You fill up your room good with smoke and out they go lively."

The house and garden were hemmed in by a high paling fence of such rude strength that the premises looked as if they were palisaded against marauding enemies. Within the enclosure were various small fig, pomegranate, and other fruit trees, and on the fence, grew several grapevines. "Them vines are scupernons," Mr. Dakin said. "They're a wild grape, but you cultivate 'em - and gee whiz! the bunches grow big as your head. The blossoms are jus' comin' out now, but the vines'll be plumb full of grapes later. We'll git all we want to eat, and the chickens'll pick the rest." "That flood we had two years ago killed a good many 
things which would be comin' on and lookin' pretty now," said Jake. "You see it was salt water. The gulf is a hundred miles away; but a heavy southeast gale raises it right up all along our coast. It's been four feet over this place a'ready and has set back mighty nigh sixty miles farther."

"This is a great country for crops," said Mr. Dakin. "You c'n raise anything hyar. You shore can."

"You can't raise watermelons," objected Jake.

"I can," declared Mr. Dakin, "and so could others if they'd only tend to 'em, but the folks hyar are too lazy."

"Well, you can't raise sweet potatoes," said Jake.

"Yes, I can too," said Mr. Dakin.

"But they don't grow big as your finger."

"Huh! what are you talkin' about?" Mr. Dakin retorted. "I never did see better potatoes than mine anywhar. I do my planting early. The trouble with the rest of you is that you don't plant till September. Common sense would tell a man he couldn't get potatoes in two weeks. Yes, sir! you c'n raise good crops hyar, and your cattle'll pretty near take care of themselves. I don't cut any hay. I buy oats some for my horses in the winter, but the cows feed on the wild canes. We have a cold spell now and then, and we feel it because we ain't used to it; but the cold never lasts long. We git only two or three days freeze at a time, and ice never forms thick enough to bear your weight. The leaves 


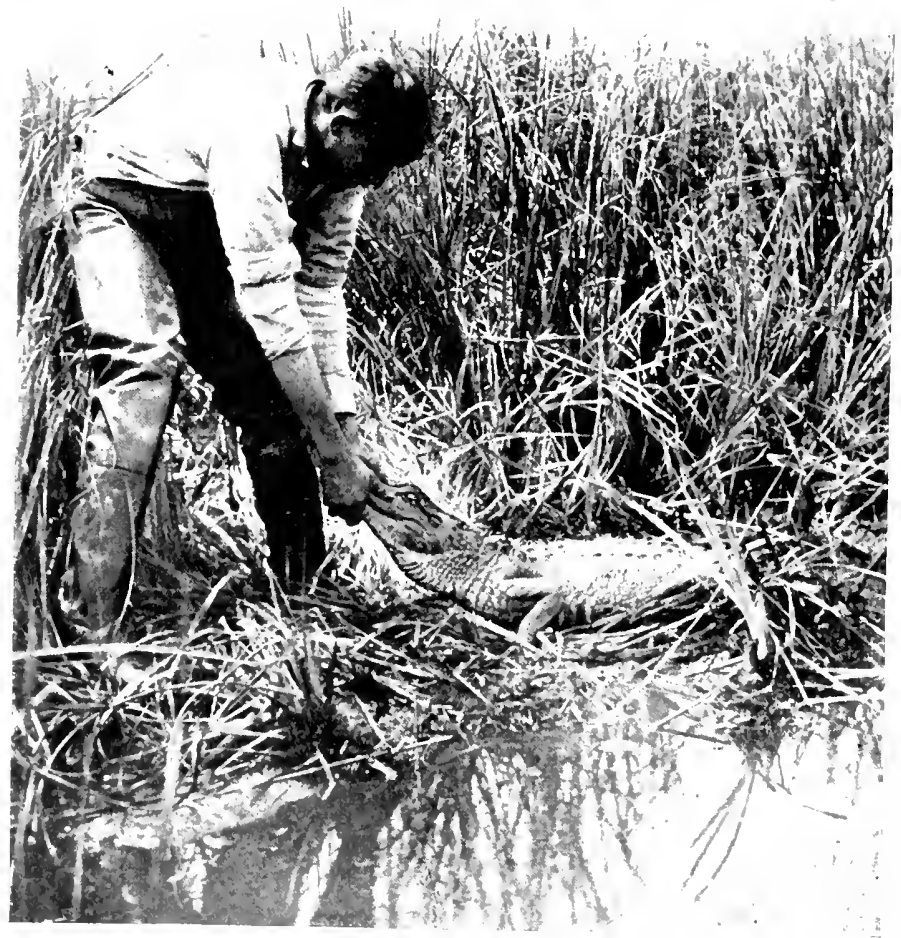

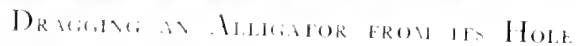


fall the last of October and they begin to come again in February."

"I see one o' your cattle yesterday goin' up the road just a bustin' it," said Jake.

"They c'n run like deer if anything's the matter," was Mr. Dakin's response. "They're wild cattle and they used to be all over the swamps hyar and didn't belong to nobody. Finally I went and chased aroun' and caught 'em. I got twenty-three. If they hadn't 'a' been killed off by hunters there'd been a thousand. Them cattle are jus' suited to this country. They c'n go anywhar. You take an ordinary cow and she would soon get stuck in the mud hyar, and that would be the end of her. Such a cow wouldn't last in this country as long as a snowball in hell. When a cow o' mine is crossin' a bayou and gets tired, she stops and rests, or if she's in mud, she'll lay right down. After a while she goes on, and she'll rest and go by spells till she gits to solid ground. Now, an ordinary cow, when she finds she's beginnin' to be stuck, makes a few big lunges that sink her in so deep she never can get out.

"Thar was a German hyar from New Orleans a while ago. He wanted to know everything, and he kep' a-askin' questions the whole time. He was white as a lily when he come out hyar, but in four days he was brown as I am. To them that's acquainted with things in this country he acted crazy; but he wa'n't - he was jus' green and hadn't seen nothin'. Why the fool would 
28 Highways and Byways of the Mississippi Valley

ketch a rattlesnake in his hands if you didn't look out for him. I had my cattle fenced in hyar one day, and I happened to speak of their bein' wild. The Dutchman got excited right off. He took his dern little old thing - his snap-shot picture machine, you know - and he'd have jumped right in whar the cattle were if I hadn't grabbed him by the coat-tails. Those cattle wouldn't 'a' let God git in amongst 'em.

“It's funny, ain't it, the things people'll say and do when they're in country that's new to 'em. Not long ago I was at the station when the train come in and I see a little girl and her father at a car window, and she pointed to some of the trees with the moss on 'em and she said, 'Oh, papa, papa, these trees have got whiskers!'”

Presently Mrs. Dakin came to the door and announced dinner. She looked pensive and worn - as if the drudgery and narrowness of her life had quenched all joy.

"Come, Colonel," said my host to me as he rose, "have something to eat with us."

To address a stranger as if he were an army officer is a compliment. In Louisiana I was often accosted by the military title he gave me; but in other parts of the South I have never risen higher than "captain."

Our dinner was served in the kitchen next the stove. The room was dismally barren, and it was hot and full of flies. "Make yourself at home," said Mr. Dakin, cordially, pushing a chair into place for me. 
I looked at the chair rather doubtfully, for the woven cane of the seat was entirely gone. However, I contrived to sit on the edge, and was comforted by the fact that the chair on my right was in the same condition. To my left Jake was established on a grocery box. The table ware was scanty, and my knife was clumsily short because half the blade was gone. We all helped ourselves to the pork and beans, the beets, sweet potatoes, corn bread, rice, and coffee. The food was not especially appetizing, but it was eatable.

We were soon back on the gallery, and I asked where the local inhabitants went to church.

“"They don't go anywhar," was Mr. Dakin's reply, "except a few of the niggers, who go to the next village four or five miles west. Some o' these niggers got so much o' this hyar church religion they won't play craps."

"A nigger is a funny animal," remarked Jake.

"He sure is!" continued Mr. Dakin. "Now do you actually believe a nigger is human? I know he ain't. He originates from a monkey or a baboon. I done been in the museums and looked at skeletons, and I can't see any difference between a nigger's skeleton and a gorilla's, only that the gorilla has got tushes. Another thing - did you ever know of an honest nigger? I don't say they're all dishonest. About one in seven hundred is all right; but even that one you ain't sure of. He may be honest for ninety-nine years and then steal if he gets a rael good chance." 
30 Highways and Byways of the Mississippi Valley

“They steal," said Jake, "but that ain't a circumstance to their laziness. If you want a nigger to work, always keep him broke. If he's got six dollars and a good suit of clothes and a pretty good hat, he thinks it's an insult to be asked to work."

About this time a visitor arrived. He was a short, stout, jovial man who had a whiskey bottle with him that he at once passed around. Mr. Dakin addressed him as "Babe," and asked him if he had eaten dinner. "No, and I don't want none," replied Babe.

"Well, you ain't a-goin' away from hyar till you git somethin' to eat," affirmed Mr. Dakin. "Myra," he called to his wife, "hyar's Babe 'most starved to death;" and Mrs. Dakin began dinner preparations again.

Later in the afternoon there came a second visitor an old man carrying a string of fish he had caught. $\mathrm{He}$ sat down on a plough that was on the gallery with various other farm tools, and said, "I was in a boat up whar the bayou jines the lake and I see somethin' movin' in the water that long" - holding his hands about a yard apart.

"What was it?" inquired Mr. Dakin.

"I don't know."

"Didn't it have any eyes or years or nose?" persisted Mr. Dakin.

"I don't know whether it did or not."

"When did you see it?"

"'Bout a hour ago." 



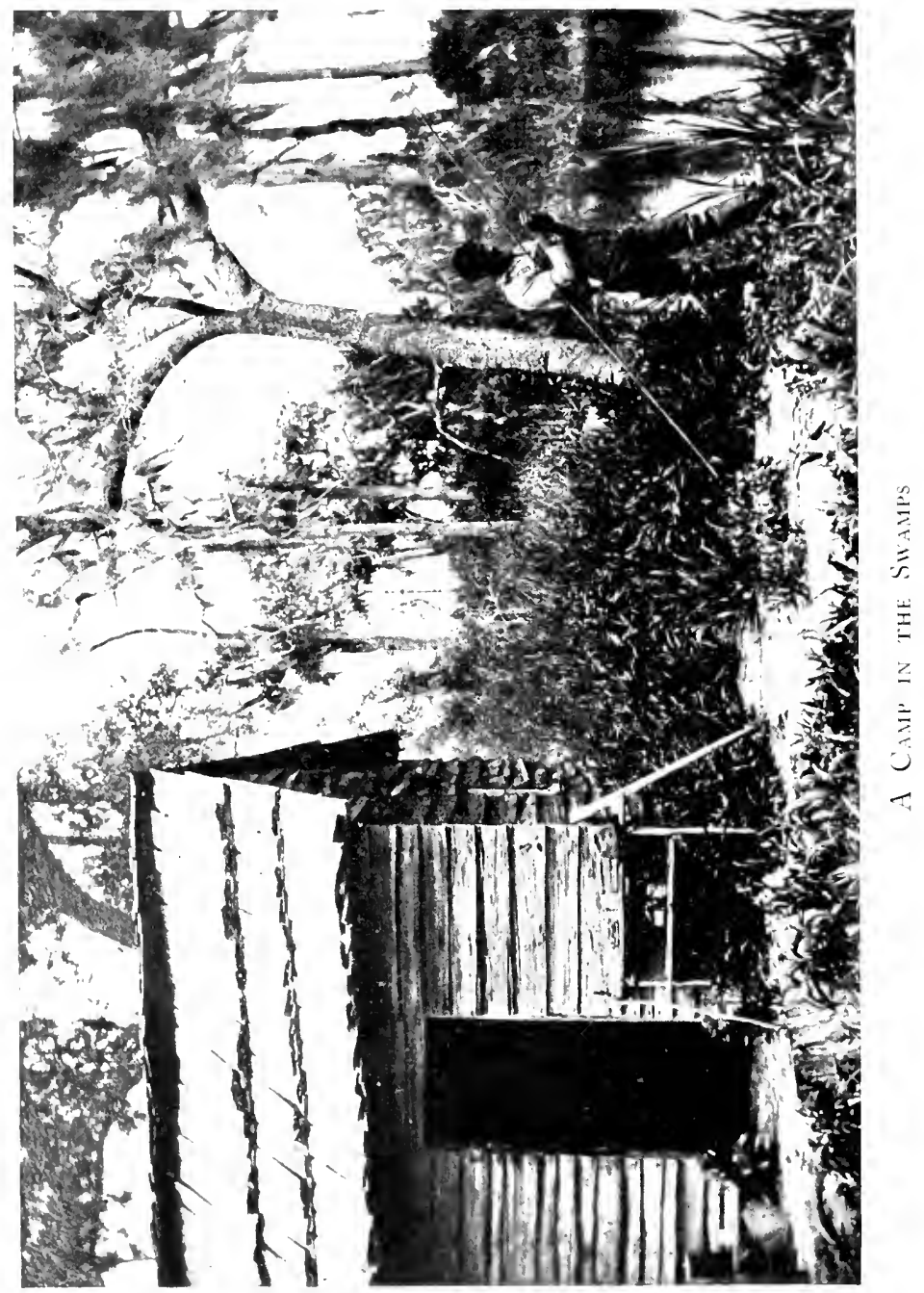


"Then you ain't clean forgot in that time how it looked. What species of animal was it ?"

"I done tol' you a hundred times I don't know."

"Might 'a' been a rhinoceros," suggested Babe.

"Like enough hit was jus' a sucker or a minnow," scoffed Mr. Dakin.

"I reckon hit was a young whale," said Jake.

"I'll take my pole an' whale you side o' the head if you say any more," exclaimed the fisherman. "I see the thing comin' with its big mouth wide open, and I tells myself, 'It's time for me to dig out.' I didn't stop to learn what kind of a animal it was."

Jake had taken his dice out of his pocket and was tossing them thoughtfully along the bench on which he was sitting. The fisherman noted what he was about and offered to "shoot craps" with him, but dickered for some advantage that Jake would not allow. "Let's have a look at your dice, Jake," said the fisherman at length.

"Them have been lucky dice for me," remarked their owner as he passed them over, "though the first night I ever had 'em I lost good and deep; but in the next month I made that up and was forty dollars to the good."

"Are they crooked?" asked the fisherman.

"No, they're as honest dice as ever was made."

"Jake," said the fisherman, "if you don't want to roll dice with me I'll make ye a bet. I'll bet one dollar 


\section{Highways and Byways of the Mississippi Valley}

to four bits that eleven and eleven are twenty-two and ten and ten are twenty too."

By four bits he meant fifty cents - a bit being an old-time coin worth about twelve and a half cents. The company discussed the proposition and twisted and turned it for some time. They affirmed very decidedly that ten and ten were not twenty-two, but no one would take the bet for fear there was some catch in it.

Then the fisherman said he would bet at similar odds that no person present could put his left shoe on first, and he pulled out his money and wanted me to hold the stakes. However, the others were wary, and after fruitlessly urging them to show their courage, he explained his ambiguous proposals.

Time sped along, and the afternoon shadows lengthened, and by and by I started for the station. On the way I stopped to look into a small enclosure on the Dakin premises which contained a tiny pond. Several glossy wild duc is were afloat on the muddy water. They had been captured when wounded, and now their wings were clipped. Jake pointed out two of them which he said were poodledoos, but he had no names for the others.

Adjoining this enclosure was a pen built around a mudhole, and there I could see numbers of young alligators half embedded in the reek. It seemed Jake was an alligator hunter, and he had caught that year 


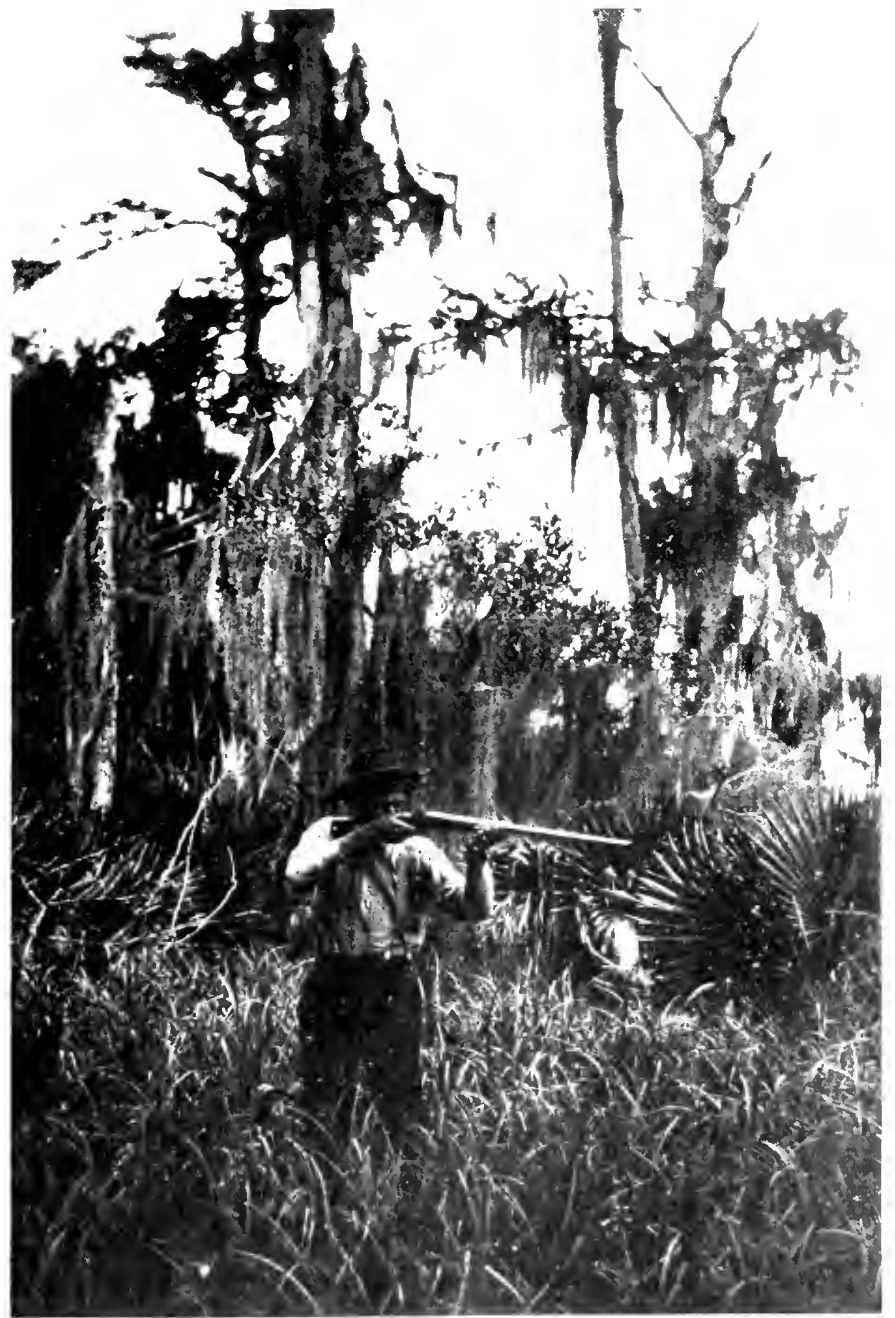

A SHOF A I DFR 


.


fully two hundred little fellows and twenty-five big ones. Anything over two feet long he called big. There was a ready sale for them in New Orleans to ship to zoos and to whoever had a fancy for owning one of these grotesque quadrupeds. Jake had his largest specimen imprisoned in his home hut, and he led the way to the two-room shanty where he had his bachelor quarters, and pulled forth a scaly monster with its jaws muzzled and its feet tied above its back. I was careful not to get very near the creature. It was helpless enough, but it could still give vicious lunges with its big tail.

Jake did not always get the alligators alive. When he killed one of any size he skinned it and cured the hide. He cooked the flesh to feed the dogs, though he often fried a portion of the tail for his own use. It tasted like fish, he said, and was very good eating.

When we went over to the station shed we found the picnickers returning, and some had lain down in the shadow of the building, and some were prowling around in the weeds looking for blackberries; but most were in the station playing craps or looking on. Nickels, dimes, and quarters were constantly changing hands, and there was rough and sulphurous language, the snap of fingers, and the light clatter of the dice as they were shaken up and rolled along the floor. It was a promiscuous crowd of old and young, negroes and whites, all intently interested and eager. Then the 


\section{Highways and Byways of the Mississippi Valley}

train was announced to be approaching, and there was a hasty finish of games and a pocketing of coin and dice, and the company gathered on the platform.

Before I left I made arrangements with Jake to go on an alligator hunt, and early one morning later in the week I again was at the little station amid the swamplands. Jake and several negro men were sitting on the heaps of curing moss. The men were moss-pickers. They were ready for work and were only waiting for the spirit to move; but they would perhaps loaf there two or three hours to learn what passers-by and those who joined their group had to say. The gathering served all the purposes of a daily newspaper as far as local interests were concerned.

Jake had the toothache. "Yo' better try cold iron," advised one of the negroes.

"Yes," said another, "cold iron de bes' thing for yo'. Hit certain will stop de toothache."

But there was no dentist at hand, and Jake presently rose to go with me. He said the trip would be too boggy for my clothing, and he took me to his hut and furnished me with some of his garments, including a great heavy pair of shoes. For his own footwear he decided to put on rubber boots. He found a pair and discarded them because they lacked holes and the heat would make them unendurable. Another pair, however, was exhumed which were satisfactorily leaky, and he pulled them on. Then he adjusted a bag over one 
shoulder, stuck a hatchet into his belt, and took in his hand a slender iron rod, six feet long and hooked at one end.

Off we went along "the dirt road," intending to go to a hunting-camp Jake had seven miles off in the wilds. The road was a narrow trail of single cart width, with streaks of grass and weeds growing between the wheel tracks, and it was hedged in on either side by the rankest kind of a jungle, in which canes were predominant. This was the main highway of the region, but it ran off into nowhere, and grew more and more grassy as we advanced. Sometimes we walked in the shade of lofty, moss-hung trees, - live-oaks, gums, magnolias, and cypress, - sometimes through blasted tracts devastated by recent fires. Ordinarily these fires only burn till nightfall, and then are extinguished by the heavy dew. The woods were vocal with bird songs, and buzzards were soaring high in the ether.

"Hit's tolerable hot," remarked Jake; and so it was, for the sun shone clear and burning, and the breeze that fluttered the treetop leafage did not penetrate into the forest depths of cane and briers and palmetto scrub. The heat was not our only discomfort. Hordes of ravenous mosquitoes assailed us and could not be kept from our hands and faces except by persistent fighting. The creatures lit on our clothing and clung to it and prodded with their poisoned lances in savage eagerness. After a few miles we turned off from the dirt road 
into an indistinct path, and waded through mucky lowlands to a dark silent bayou, which we crossed on some half-sunken logs embedded in the mud of its shallows. On we went, following the irregular windings of the path, long-legged Jake striding on ahead and I coming after, taking care to step along briskly enough not to be left behind in that lonely wilderness.

Presently Jake stopped and cut a cane a dozen or fifteen feet long that he intended to use as a prod when we came to the marshes where the alligators lurked. A little farther on the trees and woody undergrowth disappeared, and we had before us the marshlands, spreading away like a green endless sea to the horizon, an unbroken level of saw-grass, flags, and prairie canes. Last year's growths had all been burned off during the winter except for a few scattering stalks, tall and withered and rustling in the wind. The rank new shoots were waist high and grew in tufts from the charred stubs. These stubs were a foot tall and the size of one's fist, and they were set in mud that varied from a watery thinness to a stiff consistency. What sweaty, weary work it was pushing through that monotony of mud and coarse grasses! It made the breath come hard and fast and the muscles ache.

We went perhaps a mile, and then Jake said I might wait where I was until he had done a little investigating. I was glad enough to stop, and I stood still and looked around. Far behind me was the forest whence we had 
come, and all about was the vast waste of marsh which would have seemed utterly deserted if I had not now and then heard the lonely cries of waterfowl. Jake had disappeared from sight, but I occasionally saw the long cane pole he carried reaching up above the marsh growths. When that too was gone from view, I was a trifie uneasy in the forsaken and unfamiliar void, and I questioned whether, left to my own resources, I could find my way back by the devious and scarcely distinguishable path through the barbaric swamps.

By and by I saw smoke curling up from the marsh grass. Jake had set it on fire to clear a path and make walking and seeing easier. I hoped the fire would not burn in my direction; for if it forged ahead with any rapidity I could not have gotten away from it. Anything more than a snail's pace was impossible in such a sticky mud and resisting stubble. But I need not have feared. So little of the marsh growths was dry enough for the flames to lick up that the fire made slight headway.

Finally I heard a distant shout. Jake had got on the trail of an alligator, and I plodded in his direction. The soil became more watery and I sank half leg deep. Several times I had to call to Jake before I came in sight of him, to make sure of his whereabouts. He was on the borders of a narrow channel of brown water that he spoke of as an "alligator slue," and which the alligator used as a highway when in search of food. 


\section{Highways and Byways of the Mississippi Valley}

The creature had a hole just aside from the slue, and Jake ran his pole half its length into the muddy cavity to let the inmate know that something was going on. Then he bent over, and holding his nose between his thumb and finger grunted with a peculiar guttural in imitation of the voice of an old alligator. He cautioned me to keep perfectly still. Near by was a muskrat's home - a heap of dry reeds. A water moccasin came from somewhere and stopped, startled at the sight of us, and then slid hastily away. We roused a marsh hen which uttered a harsh cry and fluttered up into view and with frightened wings sped to safety.

Jake watched the water intently, repeating the grunting at intervals. There was a slight movement at the surface, and he made a sudden grab and out came a little alligator a foot long. He grunted again and secured another little fellow, and pretty soon a third. Then the ground quivered faintly and the long pole trembled.

"That's the big one - the mother," whispered Jake, and resumed his vocal gymnastics.

In a few moments there was just the least ruffling of the water, and before I could discern the cause Jake had plunged in both hands and was pulling forth a seven-foot monster firmly gripped by the jaws. But it was bedaubed with clay so that it was very slippery, and when it gave a sudden twist and turn Jake lost his hold. The beast rolled over into the slue, and with a vigorous 
splash of its muscular tail sent the water flying over us and in a twinkling was back in its hole.

Jake was mad, and he made some remarks more vigorous than elegant and began thrusting his iron rod into the soil. He could prod the creature out, he said, but as that was likely to injure it he soon decided to try the persuasion of his voice once more.

This time he imitated the cries of the little alligators. The monster responded to this appeal to its maternal instinct, and Jake caught it in the same way as before, drew it out on the mud, and jumped on its back. Then he took a cord from his pocket, tied its mouth fast shut and fastened its legs over its back and had the beast at his mercy. It was the personification of ugliness, yet I could not help feeling sorry for it and sorrier still for the little alligators, with their soft bodies and pathetic eyes. In the unmitigated loneliness of the bog, the pleasures of life were not very apparent. Nevertheless, I suppose these creatures are in their nature suited to the environment. Jake said the marshes were pretty thickly populated with them, and that there were at least forty big ones in a lagoon not far from where we were.

My comrade had put the little alligators into the sack he had brought, and he now fastened it around himself and hoisted the big beast on his shoulder. Then he staggered away through the mire and shallow pools and slues toward the comparatively firm ground of the 
40 Highways and Byways of the Mississippi Valley

swamp - and what a relief it was when we escaped from the dismal barren of the marshlands!

Our next objective was Jake's camp, about a mile distant; for there we could get drinking water, and we were very thirsty. Jake said he did not like to drink from the swamp pools and bayous, because the water was apt to make one sick - "though I have drank it a many a time," he added, "when I couldn't get any other handy.'

We did not carry the alligators to the camp. Jake tied a cord around the body of the big one and then doubled the creature up and put it in the bag, the mouth of which he tied up securely. Afterward he fastened the cord that was attached to the alligator's body to a stump. He said these precautions were necessary because it would perhaps flop around and try to get loose, and if it succeeded he would have serious trouble finding it again. "Hit can go a whole lot faster'n I can walk," he declared.

My shoes were full of muddy water that churned about at every step, and my feet were chafed and blistered, so that when we started for the camp I could not muster up much speed. A vague path led thither through tangles of buck brush and palmetto scrub. Often we had to step over fallen tree trunks or make a detour around the larger ones. The region had been heavily wooded a few years before, but in a dry spell a fire had burned for twenty days among the great 
oaks, cedars, and magnolias, and few escaped. Yet many dead giants still stood, and the rotting forms of numerous others strewed the undergrowth. By and by we came to a dark stream which we had to wade. It was knee deep, and my shoes became more water-logged than ever. I was so weary I could hardly drag myself along, and the swarming mosquitoes never ceased persecuting us.

The camp was in a pretty spot on the borders of a bayou that was alive with fish constantly making little leaps above the surface. Here stood a hut built of rough boards split out of cypress, and here Jake and Mr. Dakin lived most of the time in the winter, hunting and trapping. "We got a right smart of game hyar last winter," said Jake. "We had eighty steel traps set, and we caught five otter that fetched us from six to twelve dollars a skin; and we caught coon and mink and wildcats and all sorts of varmints."

A trough under the eaves of the hut ran the roof water into a barrel, and to this receptacle Jake resorted with a rusty tin can and drank with evident relish. "Is it good?" I inquired.

"You bet it is!" was his response, and I drank, too, but not with his enthusiasm; for the surface was strewn with leaves and mosquitoes, and both in color and taste the water was far from perfect.

We loafed around for a half hour, ate a lunch we had brought, and then started on the long tramp homeward. 
42 Highways and Byways of the Mississippi Valley

We picked up the alligators on the way and kept on steadily for four or five miles when Jake put down his load remarking, "I reckon I've packed that alligator far enough. He'll weigh nigh a hundred pounds, and he's gin me all I want to do for one day. I'll come up hyar and get him to-morrow."

So he thrust it into the sack and tied sack and all to a small tree. The little alligators he wrapped up in his handkerchief to carry along; but before we started he pulled off his boots and took a look inside. "My feet are on fire," he said. "Hit's jus' a-smokin' in thar," and he heaved the boots over into the brush where the alligator was, and walked the rest of the way in his stocking feet.

About two miles from the hamlet we came to an empty wagon in the road with three stalwart negro mosspickers standing around it. "What are you all doing ?" asked Jake.

"Our horse done run away home," was the reply.

They had unhitched it to let it feed, and it had taken advantage of the opportunity to depart. They could have worked the remainder of the afternoon loading the wagon, but they were apparently glad of any excuse to quit, and they each lit a cigarette and went on with us single file through the forest jungle.

We arrived at Dakin's stiff and lame, and sat down on his gallery to revive. Dakin soon came in from a field where he had been planting corn, and began spit- 
ting through the hole in the gallery floor and asking what luck we had had. After we finished relating our adventures, Jake, who had been watching the approach of a boy on the broken causeway that spanned the bayou, said, "Hyar comes Rob toting a snappin' turtle. That boy'll waste a whole day to ketch one o' them, when he had ought to be workin'; though he ain't strong enough for his work to amount to much. He got a laig about as big as a good-sized crane's."

Rob soon came in at the gate. He eyed Jake and said, "Look like you half dead."

"Half dead!" exclaimed Jake. "I could jump up and lick ten such as you this minute."

Rob unloosed the big, horny turtle on the gallery and amused himself by poking it with a stick, at which it would snap its jaws with savage courage. Presently a colored woman came to the house on some errand and stopped to observe the turtle rear and bite. "What'll you give for him?" asked Mr. Dakin. "You need some fresh meat at your house, don't you?"

She thought the turtle was worth fifty cents, and Mr. Dakin had Rob secure it so she could carry it. This the boy did by letting it close its jaws on a cord which he passed around under the rim of the shell and knotted near the tail. It was now well muzzled, and the woman went off with it.

The people on the swamplands plainly lived close to nature, but it was a closeness that was half barbaric. 


\section{Highways and Byways of the Mississippi Valley}

Their dwellings were primitively rough, their farming and gardening of the crudest sort, their discomforts many, their pleasures few. They looked to the forest and waters to support them and to supply much of their daily food. Hunting, trapping, and fishing were their chief interests, and they were always on the watch to waylay the wild denizens of the boggy jungles. To me as an onlooker all this was quite fascinating, yet sharing the life even for a short period had serious drawbacks. The mosquitoes had blotched my hands and face with poisoned swellings, the numerous wood-ticks and redbugs I had encountered had left their marks, and it was many days before my blistered feet healed. I could not help feeling that I had hitherto never half realized the comforts of civilization.

Note. - Any very intimate acquaintance with the moss-pıckers and alligator-hunters entails some hardships. Food, shelter, and travelling are all poor, and you never know just what unusual discomforts you may encounter. The country where these primitive people live is, however, quite accessible from New Orleans, and one can go out on the train, stay a few hours, and then return. Even then the enterprise is more picturesque than agreeable, unless you have a fancy for roughing it. 


\section{III}

THE LAND OF RICE AND SUGAR

TN the southern Mississippi valley, on the low levels behind the protecting upheaval of the 1 levees, rice and sugar are the staple crops. You can travel for scores of miles and encounter little else than the broad sugar and rice fields, and a succession of populous farm villages.

I found the aspect of the country unusually interesting and attractive. The soil looked immensely fertile and well-tilled, the homes were suggestive of thrift and prosperity, and the wide, clear expanses under cultivation intermitted very prettily with the white villages snuggling among the tall trees. It is not to be inferred that white buildings were universal, but they were predominant, and while paint was beyond the means of the humbler folk, they could secure the prevailing tint cheaply by whitewashing. In fact, whitewash is quite an institution in the rice and sugar country. It is used very freely on barns and sheds, negro cabins, hen-coops, and fences. The man who is particular about appearances and wishes to keep his premises in ideal shape, whitewashes everything in sight once a year. 
46 Highways and Byways of the Mississippi Valley

The fences are very substantial, and form such stout bulwarks about the houses, dooryards, and fields that they make the villages look almost feudal. Occasionally a fence is of wire, but posts and rails, or pickets, are more usual; and unless a fence is "horse-high, bullstrong, and pig-tight," it does not meet with general approval.

The large houses sit well back from the road, and with the fine trees about them they convey a charming sense of placidity and hospitable ease. A great gate gives entrance to the grounds, and sometimes a stile climbs over the lofty fence beside the gate. The stile is especially for the children, who would have difficulty in handling the heavy gate.

The village of Nazaire, where I stopped for several days, was like most of the river hamlets - an odd mixture of fine residences, shed-like country stores, and negro cabins. The negroes lived mostly on the side lanes or behind the big houses, where their hovels were not conspicuous. Many of the cabins were doubletenement structures, consisting for each tenant of a room for general use, including sleeping, and a shedroom for a kitchen. Neither apartment was large enough to swing a cat in.

One cabin that particularly interested me had walls of "mud." Such construction was formerly common. The wooden framework of the house was first put up and slats nailed to it. Then the space between the 


\section{The Land of Rice and Sugar}

studding was filled in with a mixture of clay and Spanish moss. Where the walls were exposed to the weather they were boarded over; but under the gallery that ran across the front and in the rooms, the brown dried mud was in view. The people who lived in this cabin said it was warmer in winter and cooler in summer than a wooden house. They seemed satisfied, though the dwelling looked ready to go to pieces. Like many other negro cabins, the window openings were merely closed with board shutters. There was not a pane of glass in the building. Of course the rooms were dark as a pocket when the shutters and doors were closed, and I was curious to learn what the inmates did in cold weather.

"We has a fire den, sah," said the turbaned old woman whom I questioned; "and we keeps a door or a window open on de side what de wind doan't blow from. Oh, yas, sah."

This house was built since the war; but across the road was an ante-bellum wooden cabin still farther gone in decay. Many of the old-time cabins had dirt floors in their kitchens, and that was the original state of the floor in this ancient wooden cabin; but latterly the dirt had been loosely overlaid with boards.

Rudeness and frailty were not confined to the dwellings of the negroes. The house where I lodged, for instance, while it was very neat and pleasant, was of the thinnest and cheapest construction. The floors teetered 
48 Highways and Byways of the Mississippi Valley

and made the furniture shake with every footstep. But there was evidence of an aspiration for the beautiful; else why was the interior woodwork painted that vivid green? and why were there those various pictures hung on the walls? Art was most lavished on the best room, where were a chromo painting in a heavy gilt frame, and a framed portrait of Jefferson Davis. Scarcely less prominent were two large colored prints, one advertising a Milwaukee beer, the second a brand of whiskey.

Nearly all the family were away every evening attending a series of meetings at a church seven miles distant. Practically all the churches of the whites in that portion of Louisiana were Catholic, and the services were in French, which was the common language of the people. With few exceptions they could speak English, too, though accent and manner were slightly foreign.

On the opposite side of the road from my lodgingplace was a great sugar-cane field. I often lingered in this and the other fields of the region watching the workers. The cane had attained a height of about a foot, and grew in rows of straggling scrawny stalks, resembling corn, but not nearly as handsome. At frequent intervals there were grass-grown ditches for drainage. These did not, however, conduct the surplus water to the river as one would be apt to expect, but carried it to the low swamps and lakes in the other direction. Ditches were a feature of the entire country. They networked the cultivated fields, the grasslands, 


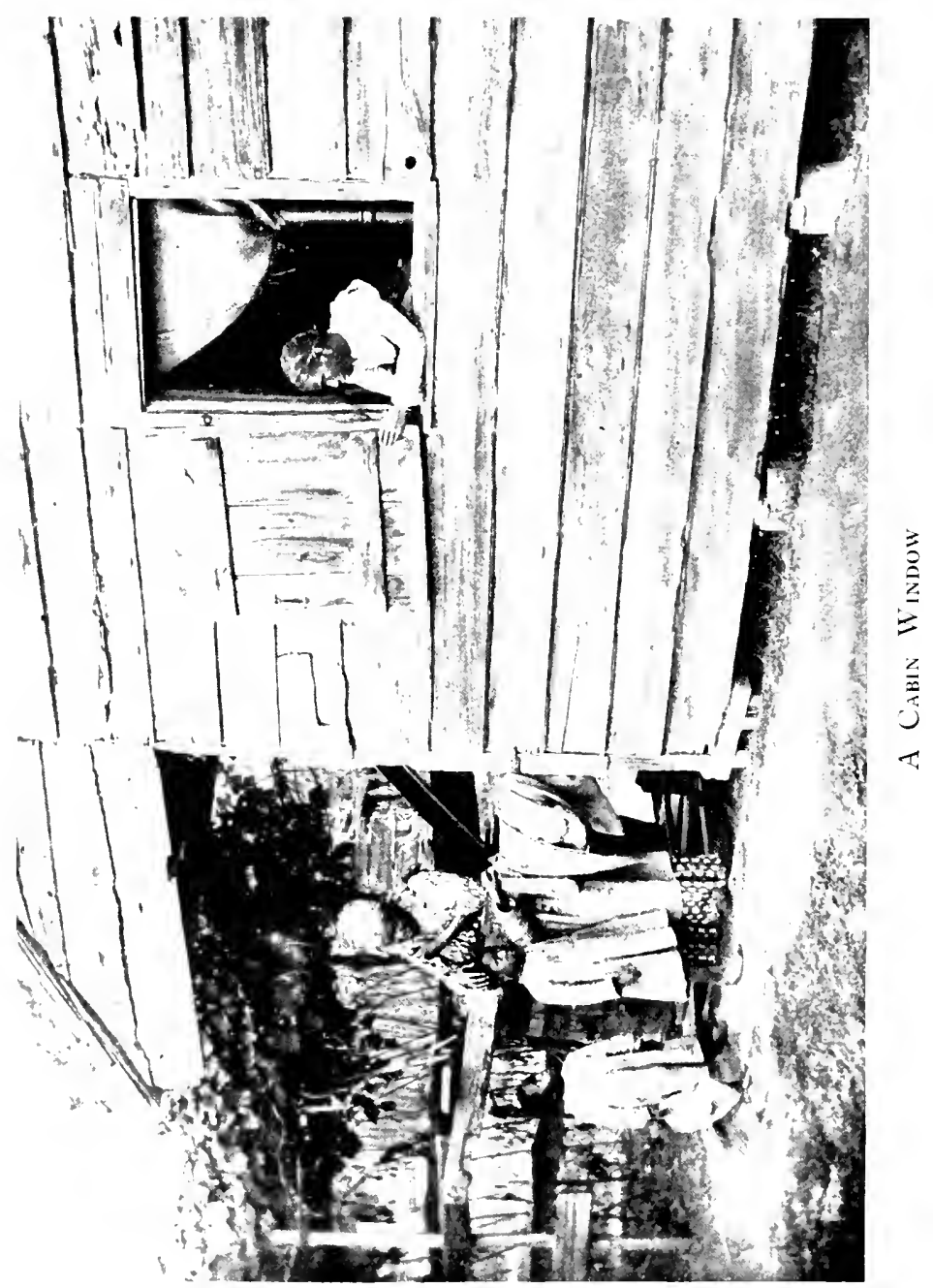


town-lots, and home premises, and there was a deep drainage ditch on each side of the highways.

The ditching was especially careful and elaborate in the rice fields, most of which were now flooded and getting green with the growing grain. The rice ditches had numerous dams; and slight ridges were thrown up here and there so that the earth was everywhere kept a little under water. This water came from the Mississippi, and during flood-time flowed in of itself; but later, when the river had fallen, it would be pumped in. There were big pipes arching over the levee and pumping engines at frequent intervals along the waterside.

The sugar-cane was getting its first hoeing, and every field had its straggling group of workers. Much of the time an overseer was among the workers, directing and urging. He rode on horseback, and during labor hours was rarely out of the saddle from morn till night. His sceptre of authority is a riding-whip or a stout stick. This is primarily for the horse, but it may be applied pretty freely to the negroes on occasion. "I don't much believe in that," said one overseer to me. "Of course, the niggers, they mo' contrary sometimes than other times; but yo' don't of ten need to hit 'em. They the best plantation help in the world, most willing and most easily managed. Yo' find fault with a white man workin' for yo', and he get mad. You can order a nigger just as yo' please, and even if yo' beat him he stays by his work. But yo' treat a white man like that, 


\section{Highways and Byways of the Mississippi Valley}

no matter if he know he in the wrong, he bound to quit."

It was hard and sweaty work for the laborers cutting the weeds and stirring the ground with their great clumsy hoes; and from time to time a water cart made the rounds. The cart only attempted to follow the plantation roads, and thence some lad lugged the water in a pail down the field and went from one worker to another. The help included men, women, and boys. The men were paid seventy to seventy-five cents a day, the women fifty to sixty cents, and the boys thirty cents. These youngsters were put two on a row, and then were expected to keep up with the rest.

I explored all the neighborhood and visited several of the nearer villages. In clear weather it was too hot for comfort walking anywhere except on the levee. There one got the benefit of the cold air from the water, and of any breeze that happened to be blowing; and it was a delight to watch the cloud-shadows darkling across the broad and lonely stream, and to look over to the opposite bank, dim and blue in the distance, with its irregular tree-masses and its houses hidden by the levee, all but the roofs. The muddy current hurrying on its seaward journey always carried with it an endless procession of driftwood, the refuse and wreckage of thousands of miles of streams above. Most of it consisted of bruised and shattered forest trees washed out of the banks, roots and all. A good deal was driven in 


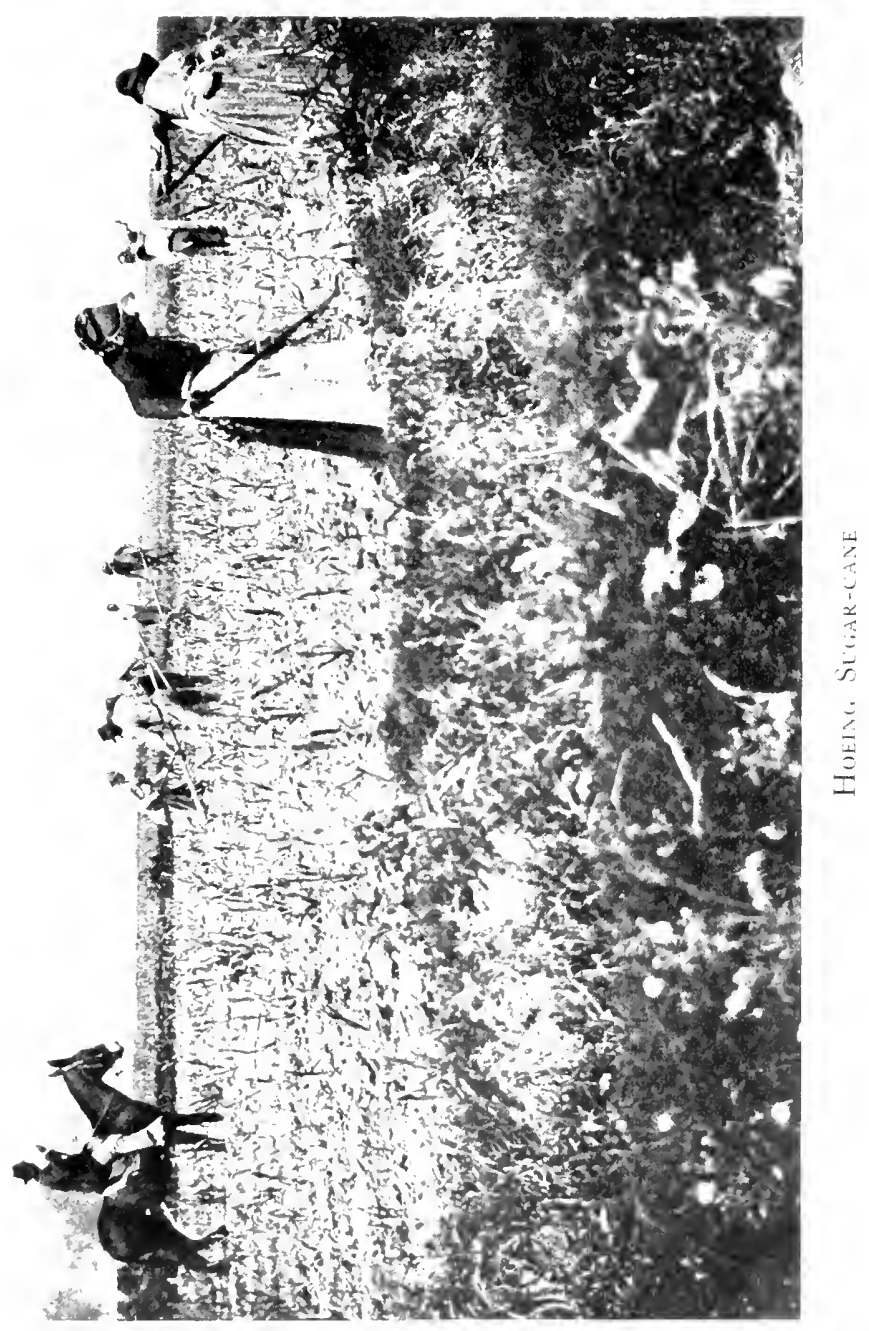



to the shore by the wind, and the river margin was much bestrewn.

It is customary to graze cattle and horses on the levee and any land that may lie outside; but when the water begins to get dangerously high the grazing is stopped, lest the turf be injured and the waves seek out the weakness and make a crevasse. One evening, as I sat by the riverside on the grassy slope of the levee near the village, a colored woman climbed the embankment from the landward and stopped to look at the stream. "Am it a-raisin'?" she asked.

I said I thought it was; and after she had considered a moment she turned her eyes toward the clouds and remarked, "I reckon we gwine to git some rain, and I don't want to be cotched in it. I done got nigh three mile to walk to whar I live. Yo' ever seen these roads hyar when it been rainin'? Whoo-hoo! If it rain fifteen minutes they so muddy yo' cain't hardly git along, and if it rain a whole day yo' almost up to yo' knees in mud. Out North, whar I was raised in Kentucky, the country was mo' sandy, and the rain might po' down hard as it please, and in half an hour after it was over de groun' would be dry."

She went off muttering to herself as she hobbled along. Not far from where I sat a boat was moored, and a little darkey was pushing about in it with great hilarity. I was quite entertained by his antics, but pretty soon a sprinkle of rain sent us both in search of 
52 Highways and Byways of the Mississippi Valley

shelter. As we came away from the levee, we heard an uproar in a near cabin. There was an angry mother's voice shouting: "Yo' come when I call yo'!" (Slap! slap!) “Yo' hear what I say!” (Slap! slap!) “I'll l'arn yo' to min' me if it take all de strenk I got!" (Slap! slap!)

Meanwhile a youngster was howling and begging for mercy and exclaiming at frequent intervals, "Oh, my Lord!"”

My companion ran and peeked through the fence, and then jumped up and down and clapped his hands and seemed greatly rejoiced and edified.

A little farther on another disturbance was in progress. Some colored boys who had been playing marbles had gotten into a dispute, and had not succeeded in settling their differences without fighting; but a scarecrow of a young woman with a good stout slab swooped down on them, and they all scattered. Now and then she made a dash at this one or that and told the horrible things she would do to them. "I'll larn yo'! I'll knock yo' daid!" she declared.

She was particularly sharp toward a boy who was her brother, and who hovered at a distance, alternately weeping and reviling. She would not relent, but shouted: "Yo' come out hyar in de road to fight about marbles! What yo' want wid mo' marbles anyhow? Yo' got de chimbley at home full on 'em; an' hyar yo' 
is a-fightin' about 'em. I'll take 'em all an' frow 'em in de pond. Yes, I will."

Nazaire had three schools. Two of them were for colored pupils, but one of these was a "pay school," kept in the little Methodist church by the pastor, at ten cents for each child per week. The free negro school was in a rickety cabin, with a big chimney right in the middle of the one room. Here sixty scholars gathered, and they filled the backless benches full and left very little open floor space. The desks that accompanied the benches were long movable affairs, with a slant on either side, so that two rows of children could sit at each desk. Underneath the desk top was a narrow shelf which served chiefly as a convenient repository for hats and sunbonnets, though chance nails driven into the rough whitewashed walls were also more or less utilized for the same purpose. Desks, benches, and teacher's table were of cheap boards hammered together by some local carpenter, and were battered and browned by long use, and much carved by youthful jack-knives. A dog lay stretched out asleep under one of the benches when I made the school a visit, and two or three of the smaller children were creeping about the floor. In the main, the pupils were quiet and orderly. Perhaps they were somewhat daunted by the stout strap which the middle-aged woman, who was their teacher, carried ready for action over her shoulder.

The chimney had a fireplace on two sides, but the 
54 Highways and Byways of the Mississippi Valley

cabin walls were so thin and leaky the building could hardly have been warmed effectively. Beside the chimney, on the floor, was a bucket of water and a tin can to drink from. The teacher said the water came from a near well, and that it did not taste good and was liable to make a person sick. But I noticed the children drank often and copiously. The teacher herself and some of the girls brought water from home in bottles. Nearly all the children were barefoot. In most instances they had their dinners with them, and some walked daily from a distance of three and a half miles. Their books were shabby and few, and not many of the pupils would attain more than the bare ability to read and write and do simple sums in arithmetic. They seldom studied geography, for their parents argue "What de use for dem to know about foreign parts? Dey ain' gwine travel."

School begins each year in March and continues without a break for seven months. The teacher said the children were not very regular attendants, and that in the five months' vacation they forgot nearly all they learned. At home they hear only "Creole French," and that makes the task of studying their English school books doubly hard.

In the middle of the morning and afternoon sessions the little ones were allowed to go out and play, but the rest were kept steadily to their tasks. This seemed a pretty severe requirement-three hours at a stretch in 


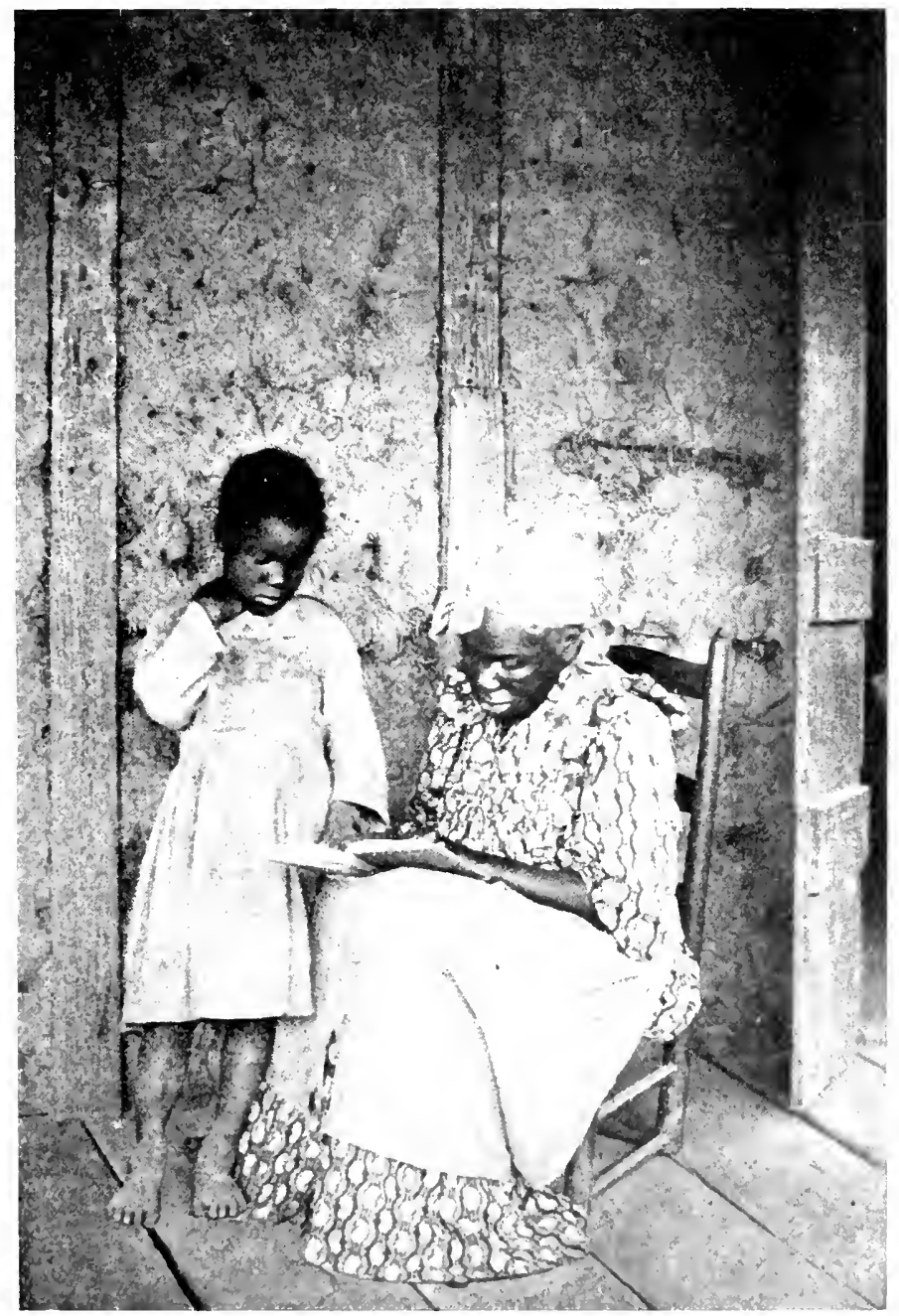

JHI Sildo: 

that crowded room and on those backless benches, which were so high that none save the oldest pupils could touch their feet to the floor.

The schoolhouse of the whites was the same in size and interior arrangement and furnishings as that of the blacks; but it was on the main road, and was newer, and in good repair. The fifteen or twenty attendants did not compare at all favorably in behavior with the colored children. They wriggled and twisted and had all sorts of circuses. They did not do much studying, and sometimes this one or that one would relapse into dreaminess and gaze out of the glassless window-openings to the hot sunshine and green fields.

While I was at Nazaire the state election occurred, and the schools were closed, and the white's schoolhouse was used for a polling-place. A good many of the voters made an all-day picnic of the occasion and hovered around the schoolhouse pretty constantly. Only about thirty votes were cast in all, and the assemblage was never large. Behind one long desk sat the three commissioners and the clerk; but their duties did not necessitate continuous attention, and they sometimes went, one or two at a time, to other parts of the room or out on the gallery. Carriages and saddle-horses were hitched along the near fences, and the voters made themselves very much at home. They even sat on top of the school desks, and some, from force of long-gone 


\section{Highways and Byways of the Mississippi Valley}

boyhood habit, got out their jack-knives and whittled off a few slivers.

At the back of the room was an array of pails and bottles and a sugar bowl. Whenever an election official got thirsty or felt the need of being braced for his duties, he retired and took a drink of whiskey or claret. Also, each person as soon as he voted was conducted thither for a reviving glass; and some imbibed from time to time afterward until they could not walk straight and their speech became thick and stammering. Every man had a pouch of fine-cut tobacco in his pocket, and at frequent intervals rolled and smoked a cigarette. If tobacco or wine or whiskey ran low, some little negro boy was called from the road and sent off in haste to the nearest store with money in his hand to buy more.

The conclave joked and gossiped and told stories and talked crops endlessly. Their manner was characteristically French, and they put much intensity of voice and gesture into all they said. One of them gave a dramatic recitation, and marched up and down the floor and entered with as much spirit into the performance as if he had been acting on the stage. Sometimes there were heated disputes over questions of politics and the methods of voting. Men shouted and shook fists and stamped in and out of the door and grew red in the face and told certain ones exactly what they thought of them. There were even those who were 
accused of the atrocious crime of being partial to the "niggers." "Where were you in '96?" demanded one man of another. "Ha! you never lifted a finger then to put the niggers down. You would not risk your life as I did and eleven others with me."

I inquired what this upheaval of ' 96 was, and I learned that in the year mentioned the county had a colored sheriff. He was capable enough, and did his duty; but he was black, and it was terribly galling to see a "nigger" in the court-house handling white men's money. So the whites determined to put a stop to such a state of affairs, and twelve men with guns went to the polls where four hundred negroes were gathered. That was a critical moment; but the blacks did not offer resistance and hastened to get away. The men with guns were at hand all day, and saw to it that the election went as they wanted it to go. Since then a black man rarely or never comes near the polls, and the twelve men are proud of their record, and consider themselves patriots and liberators worthy of special distinction.

The proceedings of election day at the schoolhouse culminated in a dinner supposed to be served at two in the afternoon; but it did not materialize until an hour later, when an old colored mammy, with a basket on her arm, made several journeys to the polling-place from a villa among the trees across the road. She came in at the rear door and spread forth a most ample 
$5^{8}$ Highways and Byways of the Mississippi Valley and appetizing feast of roast chicken, beef steak, potatoes, rice, shrimps, cakes, and coffee. I was present as a guest; and though the room was barn-like, the tableware scanty, and the slant-topped desks not very well suited to hold one's plate, yet the affable hospitality of the Louisiana sugar and rice planters made this dinner one of the pleasantest incidents of my stay in that fertile region.

Note. - Tourists who wish to see the sugar and rice country can, with advantage, make New Orleans their hotel residence. Go from there by train to some characteristic village, and then hire a team and drive about. Accommodations are poor in the rustic hamlets, yet not distressingly so, and many persons would perhaps enjoy for a short time the plain fare and rude quarters. The life on the big plantations is decidedly interesting, and in many ways unique. 



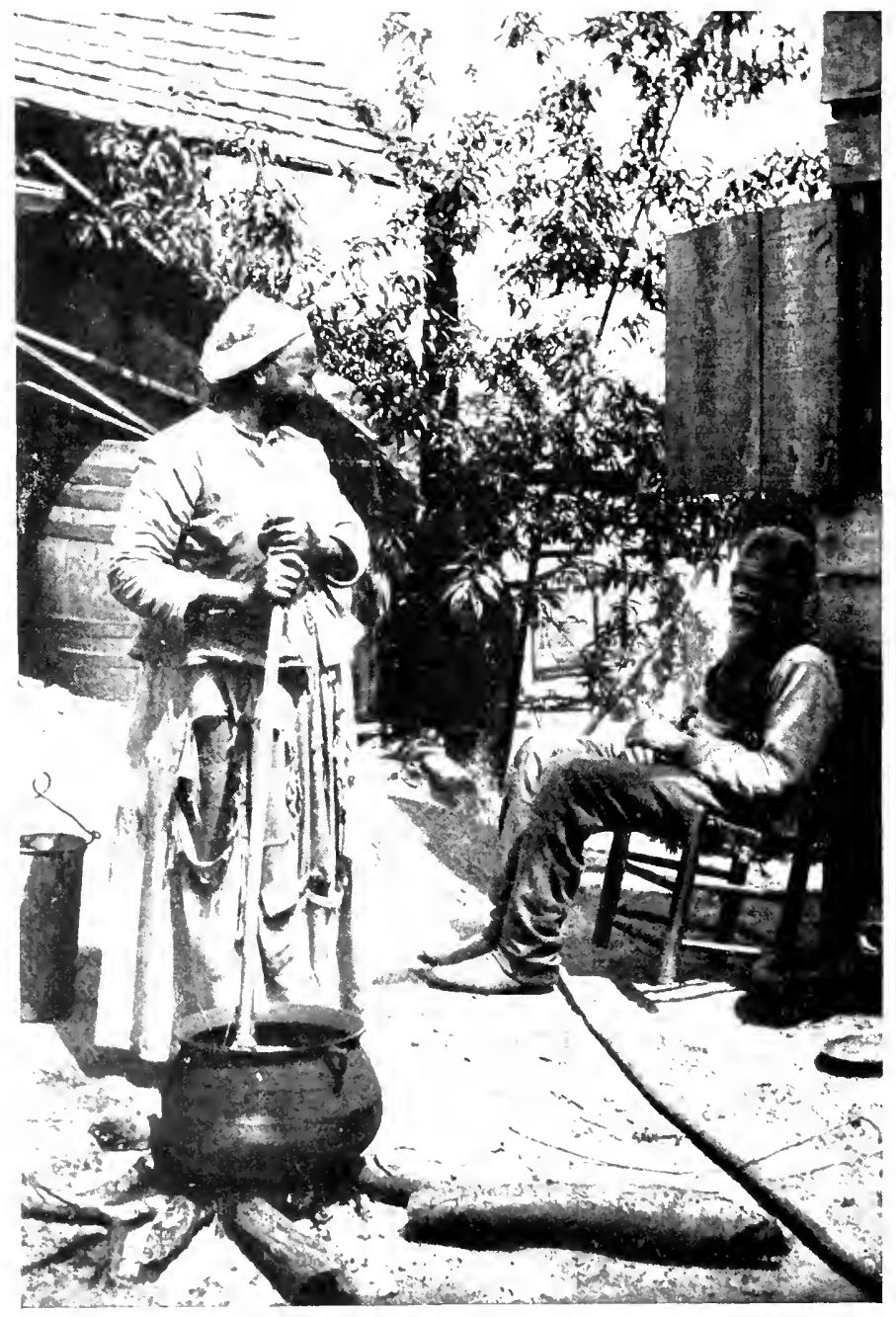

IN THE HEA OF THE DAY 


\section{IV}

\section{SPRING IN MISSISSIPPI}

T $T$ was in the late dusk of an April evening that I arrived at Vicksburg, and I picked out a hotel at random. My choice was not altogether happy. The building was big and gaunt, and the worse for wear, and the rooms were barren and battered. Yet it had the interest that age gives; for it dated back beyond the war, and its proprietor was a gray-bearded ancient who fought in the Confederate army. It stood on the brow of the steep hill that skirts the Yazoo River, and from my chamber window I looked down on the stream and the lights of the various craft that were moored along shore. Across the street some one had a phonograph, and the hoarse crackle of songs and jokes from the machine was pretty constant; but in the intervals I could hear from the lowlands the thrill of the toad's long-drawn gutturals.

A half-moon was shining encircled by a great hazy ring. Its light revealed dimly a broad reach of watery landscape extending far westward. Over there somewhere, a mile or two away, was the mighty Mississippi. Formerly it made a wide curve and swept past the bluff 


\section{Highways and Byways of the Mississippi Valley}

on which the city stands; but it some years ago cut through a neck of land and left Vicksburg stranded inland. However, before the old channel had filled up, the Yazoo was induced to flow through it, and thus the place still has the benefit of the river traffic.

In my rambles about the town I found everywhere much of the unexpected and picturesque. The buildings cling in a compact mass to the bluff skirting the river, and lift one above the other on the precipitous slope in a very odd jumble. For this effect the lay of the ground is largely responsible; but the structures themselves right in the city centre often offer curious contrasts of the substantial and modern elbowing the shabby and antiquated.

The queerest part of the city is on a big rough hill just beyond the business section up the river. This hill is nothing but clay; yet the clay is so firm it retains its shape even on slopes almost perpendicular. On the side toward the stream the hill rises in an upright wall, much overgrown with trees, grass, and shrubbery. Now and then a rude little hovel finds a clinging-place in some irregularity of the bluff; and there are occasional rough ladders and stairways that give access to the height. The upland is crowned by as strange a helterskelter of cabins, fences, paths, and devious lanes as ever existed in any African jungle. Every household has apparently established itself at chance, and the sight of such an assemblage of squatters' cabins, and 
such a massing of suburban population as the halfwild slopes and hollows of this region revealed, was in its way quite impressive. Most of the houses were built of wood, but there was one rambling dwelling constructed wholly of old iron rubbish, "without enough wood in it to make a good fire," as a neighbor explained. Its owner had a mania for collecting discarded metal, and all the vicinity of his castle was littered with heaps of rusty worthless wreckage.

I stopped to speak with an old colored woman who was preparing to wash some clothes she had boiling in a kettle set on a little fire in the yard. Her poverty was evidently extreme, and in our chat I questioned whether her life in the days of slavery was not easier and happier than now.

She said, "No," very emphatically; and added, "We was raised up jus' like cattle is, and we experienced hard times, mister, we shore did. I rather git along wid eatin' wunst a week, an' den only bread an' water, dan be a slave wid plenty. If you was a slave and ran away dey had nigger dogs to chase yo' dat'd tear yo' all up; but of co'se some masters was a heap meaner'n yuthers. Dey didn't keer to have yo' know nothin'. Once a black woman started to learn us out of a blue-back elementer [Webster's Bluebacked Elementary Speller], an' dey whipped her all night. We had to work long days den, and I never seen de sun rise while I was in de house. I'd be in de 
62 Highways and Byways of the Mississippi Valley

cotton fiel', and many a time I'd be wet as a rat wid de dew."

She was interrupted by her husband, a gray old man, who came hobbling up the hill with a pail in one hand and a hoe which he used as a cane in the other. He had been a resident of the place since childhood, and was in the city when Grant besieged it in I862. Presently he was telling of his war experiences. "Along in de winter," said he, " de Union men, dey closed in all aroun' us. Dey held de river up above an' down below, an' dey shut us off on de lan' side, too, an' vittles begun to git sca'ce an' expensive. By de end er March dey was a-firin' der shells into de town, knockin' houses to pieces an' killin' folks, and ev'y fambly got itself a cave dug. Dis hyar clay is ve'y good for cave digging, an' dey hollowed out all de hillsides. Each fambly had a room in de clay wid props inside to keep de top from tumblin' down on 'em; and some made two rooms wid a door between. I reckon it cost as much as fifty dollars to dig de best caves. Dey had beds in dar, an' whenever de guns begun a-bombangin' dey run to de caves. Sometimes dey be rouse out in de middle er de night an' run fo' de caves half dressed. De caves wa'n't no ve'y nice places. Dey too damp an' musty.

“Supplies was all de time harder to git, till we hadn't no coffee, no flour, no cloth, no shoes, or no beef meat; and dey print de newspaper hyar on de clean side er wall-paper. People got to eatin' mule-meat; an' rats was 



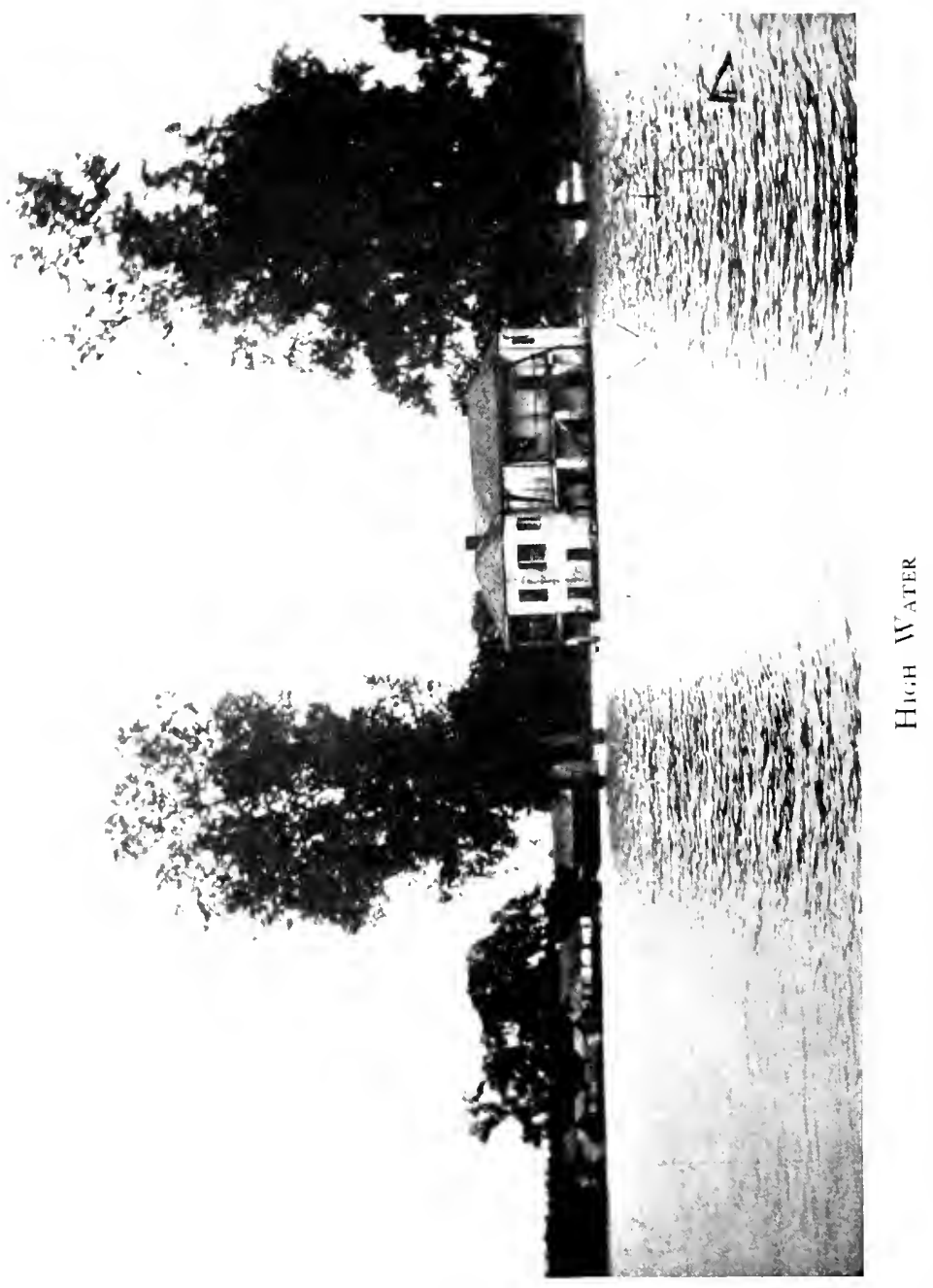


killed an' skinned an' sol' fo' meat, too. Some er de soldiers starved to death; an' yit dis place sich a natchul fortress it didn't seem like de Union fellers ever git it. Dar was guns on all de town bluffs, an' we had one gun we call 'Whistling Dick,' becaze when it fire a shell dar always be a long screechin' soun'. Dat our bes' gun, an' we know it bus' a big hole in de Federal army ev'y time we hear it screech.

"Well, I reckon we might 'a' pulled through if it hadn't been fo' de Union gunboats. We been thinkin' all along dey couldn't never git at us, caze we was boun' to knock de stuffin' out'n 'em if dey come in sight. But one night I happen to be out 'bout twelve o'clock, an' I see it lighten; an' yit de moon was shinin' an' dar was no clouds or soun' er thunder. 'Dis mighty queer,' I say, an' I run an' woke up my master. We went den an' look at de river, an' dar was de Northern gunboats wid barges er hay tied to 'em to protect 'em. All de firin' we could do couldn't stop 'em; an' after dat it didn't seem much use to hol' out no longer. So de town surrender, and I jined de Union army. Yas, I was in de rozd dozen Massachusetts regiment under Lieutenant Dodge."

On an adjoining hill was a national cemetery, thick-set with soldiers' graves, a beautiful spot, quiet and green, and receiving the best of care; yet it was nevertheless melancholy and lonely, for one could not forget that the sleepers there were far from home and all their kindred. 
64 Highways and Byways of the Mississippi Valley

In a little glen back of the cemetery was a tiny whitewashed cottage, on the shadowed side of which sat an elderly colored woman and a small girl eating bread and milk. Some hens and chickens were picking around and watching the eaters, hopeful of getting a share of the feast; and a dog lay on the ground also alert and expectant; and a pig was rooting close by, and he, too, seemed to be watching for the bestowal of a portion of the bread and milk. It was a hot afternoon, and I stopped to talk.

Every negro at all advanced in years has something to say about old times, and the woman at the cabin in the glen was no exception. "I was raised in Ferginia," said she; "and I was a house servant. I tell you I had mo' good times den dan I do now. People say dat evy'thing gittin' better; but I ain' no chicken, an' I know dat ain' so. I been thinkin' 'bout de chilluns. Are dey improve? No! Dey ain' smart an' dustless [industrious] like dey was befo' de war, an' dey ain' so mannerble, white or black. Den again, how is it about de Lord's day? Lots o' places it's gittin' so dey ain' no weeks. Folks work Sundays same like any other days. Yas, de worl' mo' wicked. Is you been in dese yere Vicksburg saloons? I'm skairt to go near de town in de night dar so much rippin' an' tearin'. Dey got so bold an' rapid aroun' hyar I doan' hardly want to go out er my house even in de daytime. It look like we so wicked we be punish soon by a great 


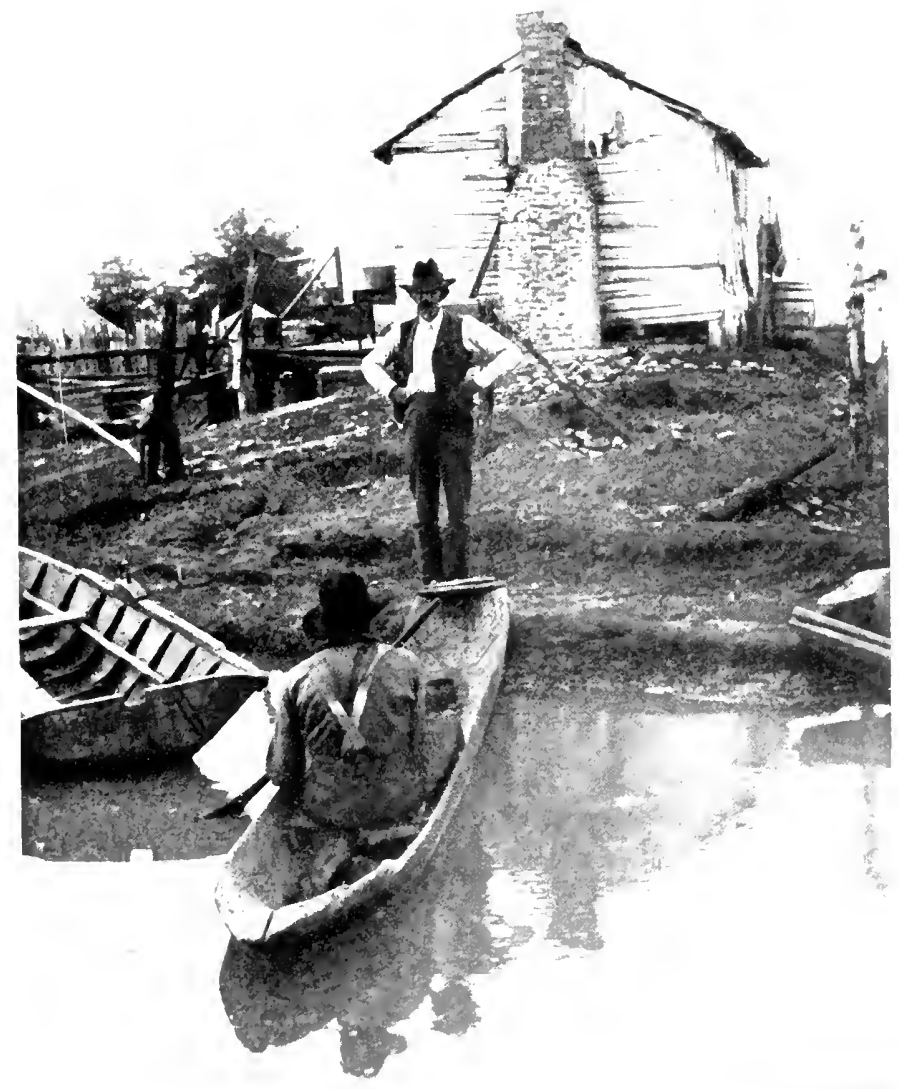

A Derout 
burnin'. De sun a ball er fire, an' de moon a lump er ice; an' I reckon if de sun git de upper han' we're all goners. Yo' know how Martinique done got burnt up. Once las' year it was so hot hyar I thought de heat gwine serve us de same way. Soon or late it's a-comin'. De Bible say de rainbow sign make us know de worl' be no mo' destroy by water. It be fire nex' time."

I spoke to the woman about the shops in the town owned by negroes; but she said there ought to be more, and she was not enthusiastic over the thrift of her race. "If a darkey got money he boun' to spend it," said she. "He know he ain' gwine git rich anyway, so he doan' try to save nothin'. Den, too, a colored man think he cain't start in business widout he got 'bout a thousand dollars; but a white man will start wid no mo' dan a few peanuts an' a little popcorn in a basket. He lays up de nickels an' dimes, an' pretty soon he git a store, an' fust thing yo' know he way up."

Just then the little girl exclaimed, "I done seen a rabbit over dar in de briers."

“Dat remin' me er de stories dey use to tell 'bout de rabbit an' de yuther creeturs when I was a chile," remarked the woman. "I thought den de tales was all true, and I was sure Mr. Rabbit ketch us if we go down to de branch in de evenin'; an' if we see Mr. Rabbit, den we chilluns would light out, skeered to death."

"What were the stories?" I questioned.

She responded with a series of several which she told 
66 Highways and Byways of the Mississippi Valley

with great animation, acting out all the parts and changing her voice to suit the words of the different characters, and now and then rising and skirmishing around the yard to illustrate the more dramatic portions.

"Well," said she in beginning, "de stories was mos'ly about how 'mongst all de creeturs Mr. Rabbit was de smartest man in de crowd. He was a sly rascal, he sho' was. One day when Mr. Rabbit an'Mr. Fox was talkin' togedder, Mr. Lion an' Mr. Tiger drove pas' wid a load er fish.

“'Look a' dar!'says Mr. Rabbit. 'I want some er dose fish.'

“'But yo' cain't git 'em,' says Mr. Fox.

“'Yes, I kin,' says Mr. Rabbit; an' he cry out, 'Hol' on, Mr. Lion! Hol' on, Mr. Tiger!'

“Dey stop, dey did, an' he run an' jump up on de fish wagon. De lion an' de tiger, dey order him off. Den he run 'way up de road an' hide in de bushes, an' when de fish wagon come along he holler out, 'Whoop, whoop, whoop, diddle-um-ding, varmints of all kinds, lions an' tigers, an' dey cain't keep my th'oat cl'ar!' “'Heyo! Mr. Lion,' says Mr. Tiger. 'What dat? I reckon we better be gittin' along in a hurry.' "So dey whip up de hoss. But Mr. Rabbit run fas' as he kin an' git ahead once mo' in de bushes, an' soon as dey come along he holler, 'Whoop, whoop, whoop, diddle-um-ding, varmints of all kinds, lions an' tigers, an' dey cain't keep my th'oat cl'ar!' 
“Dat skeer Mr. Lion an' Mr. Tiger so much dey jump off de wagon an' run like dey sent for. Den Mr. Rabbit he drive off wid de fish, an' de nex' day he 'pint a time fo' a big feast. All Mr. Rabbit's frien's come excep' Mr. Fox, an' bimeby he come too, but he was all limpy an' rasslefrassled. 'Boo-hoo-hoo!' he cry, 'I done met up wid Mr. Lion an' Mr. Tiger, an' dey 'cuse me er stealin' der fish; and dose fellers, dey mos' tore me all to pieces.'

"Dat de way de rabbit always doin' de mischief, an' some one else gittin' punish fo' it. Yas, de rabbit mighty slick. He de cunningest li'l' ole creetur in de woods. Sometimes when he chased by dogs he find a long holler log lyin' on de groun' wid a hole jus' large enough fo' him to slip thoo', an' he go in one end an' out de yuther. De dog foller his track to de log, an' he spen' his time pawin' at de place de rabbit went in, an' de rabbit git safe home. But his bes' trick when he runnin' from de dog is to take a circle aroun' an' come back to his track, an' dar he stop an' lick his paws to take off de scent. Nex' thing he fotch a few jumps out sideways, an' sit still an' let de dog run pas'. Den he go off about his business."

\section{MR. FOX LEARNS WHAT TROUBLE IS}

"In dese ole stories de rabbit always on a complaint when dar any work to do, an' he never leave off tellin' about his troubles. One day Mr. Fox say to 
68 Highways and Byways of the Mississippi Valley

him, 'Seem like you have troubles all de time, Mr. Rabbit.'

“' Yas,' Mr. Rabbit reply, 'ev'ybody always atter me, diggity-diggity, an' I have nothin' but trouble.'

" 'Well now, Mr. Rabbit,' de fox say, 'I wish yo' 'splain to me what trouble is. I doan' know rightly what yo' mean by trouble.'

“' I cain't tell yo' de meanin' er de word,' says Mr. Rabbit; 'but I kin show you de meanin'.'

“' I wish yo' would,' says Mr. Fox. 'I done heard yo' talk so much about trouble I want to understan' what it is like.'

“'Ve'y well,' Mr. Rabbit 'sponds, 'de nex' hot day yo' go out in dat ole fiel' near my house, an' yo' lie down an' sleep dar on de knoll whar de sage grass grow thick, an' I'll come an' wake yo' up an' show yo' what trouble is.'

"So de nex' hot day de fox go to de ole fiel' an' lie down on de knoll in de sage grass, an' pretty soon he soun' asleep. Mr. Rabbit come an' fin' him dar, an' den he set de grass on fire in a ring all aroun' Mr. Fox. Soon as he done dat he give a yell an' say, 'Mr. Fox! Mr. Fox! Yo' wake up, an' doan' was'e no time 'bout it, needer!'

"Mr. Fox, he wake up, an' he say, "What all dis smoke, what all dis fire I smell, Mr. Rabbit?'

“'Dat trouble, Mr. Fox, dat trouble,' says Mr. Rabbit, an' he lit out fo' home. 


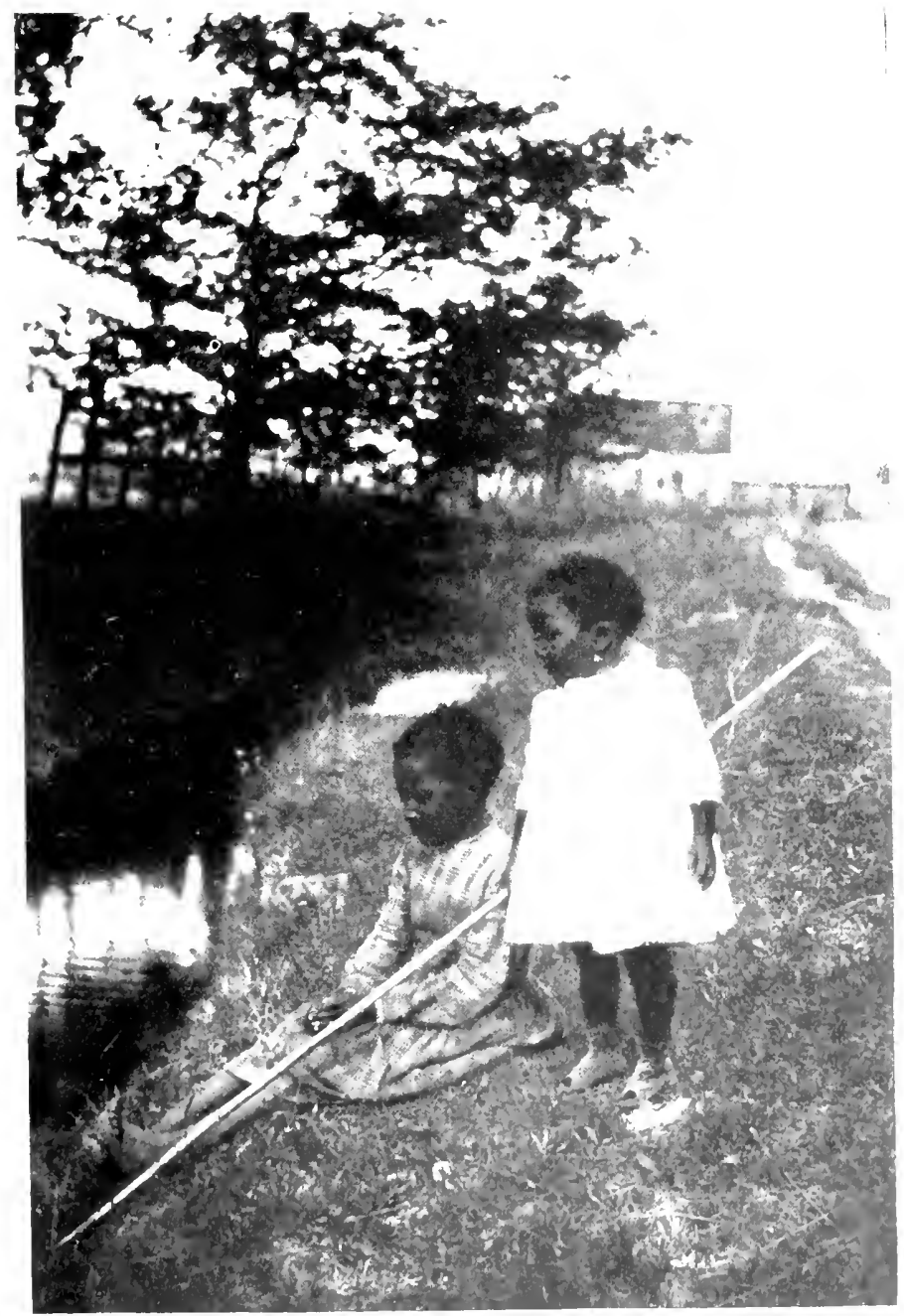

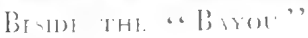



“Mr. Fox certainly learnt what trouble was, an' he come mighty nigh bein' burnt to death."

MR. WREN BORROWS MONEY OF MR. BUZZARD

“Did yo' ever hear er how de wren borrowed some money er Mr. Buzzard? Mr. Buzzard, he willin' to 'commodate Mr. Wren, only he ask, 'When yo' gwine pay me?'

“' 'Soon as I git growed,' says Mr. Wren. 'Soon as I git to yo' size, Mr. Buzzard,' says he.

"So Mr. Buzzard loant him de money, and atter dat, once in a while he call on Mr. Wren to see when dat money be paid back. Mr. Wren always say, 'Soon as I git growed;' but ev'y time Mr. Buzzard take notice Mr. Wren ain' gittin' no larger at all.

“Mr. Buzzard was mos' as slow in his thinkin' as Mr. Wren was in his payin,' but at las' he begin to suspect somethin' not right, an' he speak to Mr. Hawk 'bout de matter. 'What kin' of a man is dis $\mathrm{Mr}$. Wren ?' he say. 'He been owin' me money dese five or six years, an' he say he pay when he git growed; but he de same size now as when he borrow it. Look like he never git growed.'

"'How dis ?' says Mr. Hawk. 'Do you reckon Mr. Wren gwine git to be de same size as you an' me?' “'I shore does,' says Mr. Buzzard.

“'Dat's whar yo' make a mistake,' Mr. Hawk say. 'He big as he ever will be. Why! Mr. Wren was a ole 
70 Highways and Byways of the Mississippi Valley

man when he borrowed dat money, an' yo'll never see it - not if yo' wait fo' ever!'”

\section{JOHNNY AND TOMMY AND THE BEAR}

The little girl had been an interested listener to these narratives. Now she asked, "What dat story, granny, 'bout Johnny and Tommy?"

"One time," resumed the old woman, "two boys by de name er Johnny an' Tommy was out in de woods an' dey come to a tall, hollow stump, and dey heard some b'ar cubs inside. Dey want to git dem cubs, an' Johnny clumb up to de top er de snag an' went down inside an' caught 'em. Den he foun' he couldn't git back. 'What I gwine do?' he holler to Tommy.

“"Have yo' got a knife?' Tommy say.

“'“Yes,' says Johnny.

“' Well den,' Tommy tol' him, 'when de b'ar come she'll go down into de holler stump backward, an' when she git low enough yo' ketch her by de tail an' prick her wid yo' knife, an' she'll pull yo' out er dar in a hurry.'

"So Tommy hid off in de bushes to see what gwine happen, an' about sundown de ole b'ar come an' climb de stump an' back down out er sight. Johnny all ready, an' he got de cubs fastened to him tied up in his jacket. Soon as de b'ar got whar he could reach her he grip her tail an' prick her wid his knife, an' up she scramble draggin' him atter her. Den Tommy holler 
out, 'Hang on, Johnny! Tail holt is a mighty good holt!'

“An' Johnny did hang on, an' soon as he got to de top he give de b'ar a push an' she tumble down an' was killed, an' de boys got de cubs an' de b'ar, too."

\section{THE STORY OF THE FRAIDS}

“I remembrance 'bout anudder li'l' boy who had to go ev'y evenin' to de pasture to drive home his master's cows. He'd start at three o'clock, but he'd stay foolin' off his time and never would git back till dark. De road pass a graveyard, an' his master say to him, 'Ain' yo' skeered to come by dat graveyard atter dark?'

“'No, sir,' de li'l' boy say. 'What for I be skeered?'

"“Why, dar's fraids dar,' de man say.

“"What's dem?' de li'l' boy ask.

“' 'Ghos'es an' things all in white,' de man say; 'an' if dey cotch yo' dat de end er you.'

“'Well, I ain' never seen none yit,' de boy say.

“Den de man tell hisse'f dat he ain' gwine have de boy wastin' so much time as he been a-doin', an' he think he give him a skeer dat make him come home earlier. So de nex' night he cover hisse'f wid a white sheet an' go hide in de graveyard. But it happen de man have a monkey dat always try to do ev'ything jus' like he see his master do; an' dat monkey, he git a pillow-slip an' put it over hisse'f an' foller his master to de graveyard. De man, he didn't see de monkey, 
72 Highways and Byways of the Mississippi Valley

an' he git on a tombstone, an' de monkey git on annudder tombstone behind him. Pretty soon de boy come along whistlin' an' drivin' de cows. Den de man raise up an' squat down in his white sheet, an' de monkey in de pillow-slip done de same. De boy stop an' point an' say, 'Dar's two fraids - big fraid an' li'l' fraid.'

“De man doan' understan' what dat talk mean 'bout de li'l' fraid, an' he look aroun', but de monkey had jump down out er sight. De man begin his motions ag'in to try to skeer de boy, an' de monkey git up an' do de same. De boy point wid his finger, an' he holler out de secon' time, 'Dar's two fraids, big fraid an' li'l' fraid.'

“At dat de man turn aroun' quick, an' see de yuther white thing, an' he git a great fright an' broke an' run, an' de monkey foller him fast as he could go. Den de boy wid de cows holler, 'Run big fraid or li'l' fraid'll cotch you!'

"What de boy had see didn't skeer him, an' it didn't make him no quicker'n he'd been befo'. Seem like yo' couldn't learn some folks nothin' nohow."

My landlord at the hotel had mentioned that there was "a heap of powerful pretty country under water along the river"; and one day I made a trip to an outlying village to see how the people fared in the submerged districts. At this particular place they took the flood philosophically enough. They were in no danger - simply inconvenienced. Some of the land 
and houses had not yet been touched, but the majority of the dwellings were quite Venetian, and were either awash with the water, or were on a narrow island that had been the breastwork of a war-time fort. I hired a negro to take me for a row, and he called my attention to stains on the whitewashed walls of some of the cabins that showed last year's flood had been up to the windowsills. "Floods like dat is a bad thing," explained my companion. "Dey ramshacks de floor, an' de furniture all comes to pieces atterwards."

The village people owned quite a flotilla of boats, some of which were dugouts. These dugouts were usually of cypress and looked clumsy and ugly, but the village storekeeper, with whom I became acquainted, told me they were very serviceable. "You don't want to git careless, though, or they'll capsize," he added. "I mighty nigh got drowned, havin' one turn over under me this year. I was duck-shootin', and I had a one hundred and twenty-five dollar gun that I was boun' to hang on to whatever happened. Another boat come to my help, and I got into it, and the thing was all over so quick I didn't have time to git scared; but when I was safe I shook like I had the ague."

There was no levee along here, and the man said they didn't want one. The flood fertilized their land, and on the whole was a benefit. They always waited till the spring rise was over before planting much, 


\section{Highways and Byways of the Mississippi Valley}

though the water now and then would come up in the summer and do a great deal of damage.

One of the local citizens who attracted my notice was a big-framed and very fleshy black man. He looked so superlatively lazy and amiable and talkative that I had the curiosity to ask how he got along in the world. I was surprised to learn that he owned a little farm, and was prosperous. Yet he did no work on his home place, because he claimed to have heart trouble. His family took care of his garden, and he carried a load of truck to town every week. That sold for four or five dollars, which was money enough to make him independently rich. I first came across him sitting by a roadside ditch chatting with a woman who was fishing. The woman was not catching anything, and seemed minded to quit. "Yo' think yo' luck won't come?" he inquired sympathetically.

"Too much fraish water," she responded.

"Yas, dat de trouble, sure as de truf," said the man. "De fish swim all aroun' de fiel's now an' git all dey want to eat, so dey won't bite yo' hook. Dem fish jus' as fat as hogs. It no sati'faction to fish when dey dataway."

"Las' week de fish in dis hyar bayou bite as soon as I put de hook in de water," remarked the woman.

"Maybe dat de consequence again when de river go down," the man said encouragingly. "Joe tell me he git plenty spearin' 'em wid his gig at night." 
"How does he do it?" I asked.

"He go in his boat wid a torch," was the reply, "an' de light draw de fish an' blin' 'em, an' he plunge his gig into 'em, an' dar he have 'em."

Not far away were some children with poles and lines lingering along the banks of the ditch catching crawfish. They were quite successful, or, as the fat negro said, "Dey do everlastingly cotch 'em now, don't dey? I reckon dey gwine have 'em fo' dinner. Summer time, when de ponds are low, yo' c'n take a rake an' scoop out crawfish by de hundred. Yo' tote 'em home an' po' hot water on 'em an' den pull de bark off'n 'em, an' de tail is rael nice. We fry de meat jus' like fish, an' it's better'n fish fo' eatin' because dar ain't no bones."

The most interesting excursion I made from Vicksburg was a steamboat trip in the Elk forty miles down the river. We started at noon of a quiet sunny day that was too hot on the land, but very comfortable on the water. Another steamer left the city at the same time, and each tried to get ahead of its rival; but we were gradually left behind. Every one on board was interested in the race, and the officers made many excuses for our defeat - the boat was not loaded right for speed, some of the paddle blades were broken, etc. Among the passengers was an old-time river captain. To him the race was peurile. "By Jove! you ought to see how they did things thirty years ago," he said. 
76 Highways and Byways of the Mississippi Valley

"Once I raced all the way from New Orleans to St. Louis. My boat was beaten and I lost nine thousand dollars that I bet on her. There was a big lot o' money changed hands every race when the boats was well matched. In the years just after the war steamboatin' was a big thing. I made one trip up the Missouri as far as Bismarck that give the owners of my steamboat a profit of $\$ 110,000$; and every man on the boat made all the money he wanted, besides. We traded with the Indians, and you could get twenty dollars' worth of furs for a string of beads that cost five cents."

Now the Elk slowed up to make a landing, and the other boat went on down-stream like a beautiful white water-creature and disappeared from view. We had stopped at a choppers' camp, and in the near woods I could see tents and oxen. At the shore were several waiting negroes. They wore red shirts that made striking bits of color amid the wild greenery of the woodland. The water was up, lapping the banktop, and the boat swung about in the swift, boiling current, and pushed its bow snug to the shore. Our black roustabouts promptly got a rope around a tree, laid a couple of planks from the boat to the land, and hustled off the bags and parcels that were to be left. Then we went on, and we had the river all to ourselves for the rest of the journey. Its vast loneliness was quite impressive, and it must have appeared much the same in the days of its first explorers. Nearly always the 



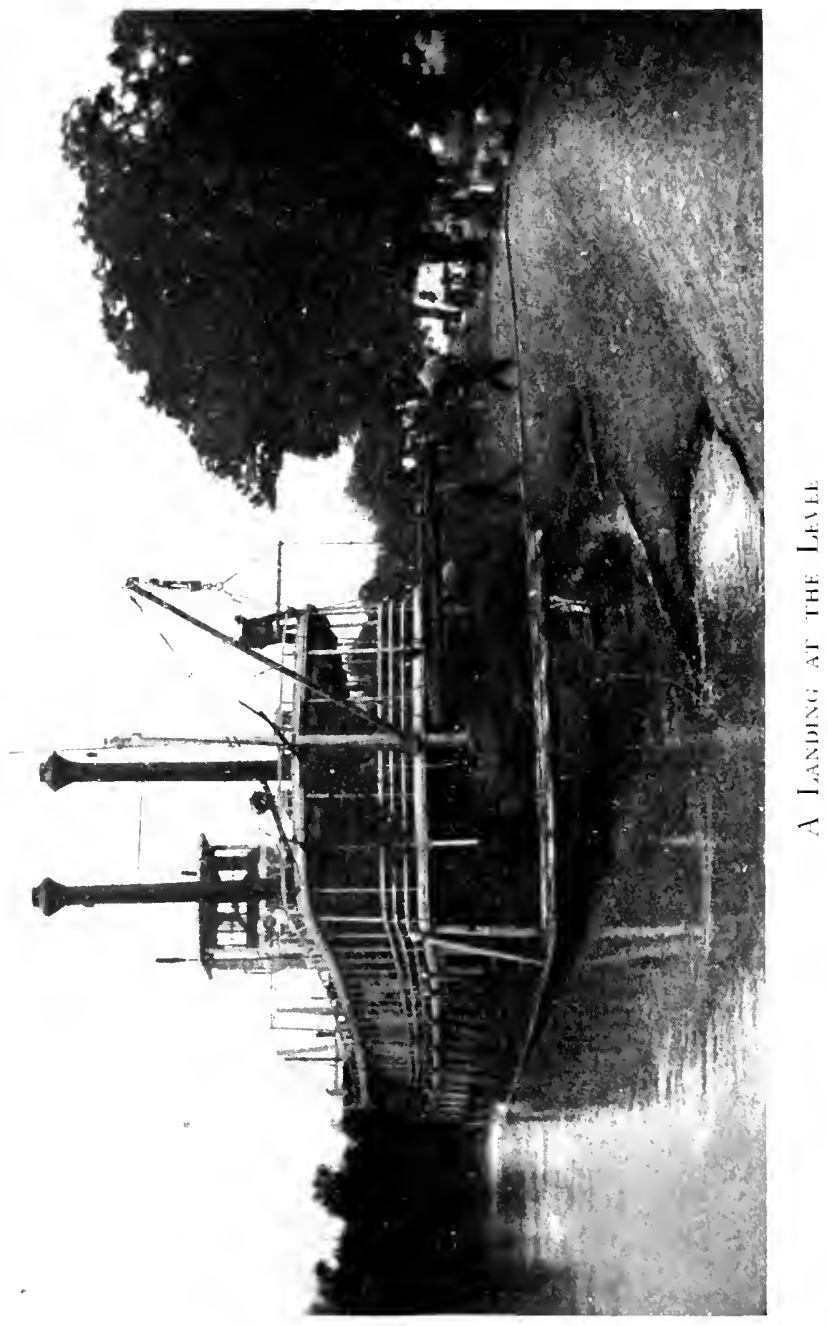


banks were wooded, but there were occasional openings affording glimpses of plantation fields and a scattering of cabins. From time to time we would butt up to the bank and discharge or take on freight, and the boat went over the same route, doing this twice a week the year through.

The passengers included four young men who were making the round trip for an outing. They spared no effort to have a glorious time, and their visits to the bar were almost unceasing. The capacity they displayed for stowing away liquor was a marvel; and they were very social and affectionate, not only among themselves, but with every one on board. Sometimes they engaged in a tipsy race about the deck. Sometimes they entwined their arms around one another and half sat, half lay in the deck chairs. Sometimes they felt their biceps and challenged each other to fight. The rest of us dodged them when we could. Even the pilot, when they came to the supper table, to which he had just sat down, rose hastily and left. "Here, come back!" one of the rioters called after him. "You got any objections to my company? I ain't no ghost. I ain't no haunt."

Again and again they treated to drinks and cigars the officers of the boat, the passengers, and such of the crew as they happened to meet. Once I saw their leader step up to the mate, pluck a half-smoked cigar from his lips, and throw it into the water. At the same 
78 Highways and Byways of the Mississippi Valley

time he handed out another. "Have a good cigar," he said.

Among the persons treated by the picnickers were a couple of negro convicts who were manacled hand to hand. Their melancholy plight touched the tender sympathies of their benefactors. "You are black," said one of the quartet; "but I have a heart, and I feel for you. Here, drink another bottle of beer; and, boys, take my advice - behave yourselvẹs while you are serving out your time, and when they set you free live right and don't get into the same trouble again."

The prisoners were on their way to a convict camp, where they were to work out their fines at the rate of four dollars a month. Presently we approached their destination, and the steamboat gave a shrill hoot with its whistle, as it always did when we were about to stop. The banks here were low enough so that the flood covered them and allowed us to go back to the levee. Behind the embankment were numerous barns and cabins, and a big, wide-spreading, white mansion in a grove. It was a great event on the plantation to have the steamer come so near, and quite a concourse of negro women and children gathered on the bank to chatter and laugh while they watched the rousters hurry the freight to shore. We passengers looked down on the crowd from the upper deck, and one of the happy four swung a beer bottle in the air and asked if any of those on the levee wanted a drink. "I'll 
treat," he cried. "Have some? Now laugh! What are you all standing there for anyway? Those roustabouts you're lookin' at are tired. Go tell 'em you'll unload! Let the women do the work, I say! Let the women do the work! Now laugh again!"

He drank the beer himself, and went down on the levee. There he found a small boy whose apparel was amazingly scanty and ragged, and he asked, "Are those the best clothes you've got?"

"Yas, sir."

"Why, they are all to pieces, and the buttons are gone."

"Yas, sir."

"You ain't fit to be seen. Don't you know that?" "Yas, sir."

"Well," said the fellow, thrusting his hand into his pocket and pulling out several silver coins, "take this money and go buy yourself some clothes, and hurry up about it."

The boy took the money and ran off, and we saw him no more.

We were a long time unloading; for there was an immense deal of cattle feed and farm supplies and household goods in great variety to be left. This convict camp was a big plantation, and, like many other plantations, it had people enough on it to make a good-sized village. Our rousters carried out most of the freight on their heads or shoulders, and their celerity and deft- 
80 Highways and Byways of the Mississippi Valley

ness in the heavy labor were a wonder. Two of them stayed on the lower deck and heaved up a burden to each man in turn, and the leader of the two often broke forth in a strange chant, to which the other responded like an echo. This chant was a monotone consisting of an improvised sentence shouted each time a bag or box was lifted to a waiting roustabout. The fragments were such as these:-

First voice. I ain' gwine leave yo' he-ere!

Response.

- leave yó' he-ere.

First voice. Take yo' load if yo' ple-ease!

Response.

- if yo' ple-ease.

First voice. Oh, Lord! Oh, Lord!

Response.

- Oh, Lord!

First voice. I'm gwine live a long ti-ime!

Response.

- a long ti-ime.

First voice. Yo' doan' know what trouble I've seen! Response. - what trouble I've seen!

Though to me the roustabouts seemed so alert and willing, they were not at all satisfactory to the mate, who, puffing viciously at a cigar, was constantly urging them to greater haste, and once in a while he let off an explosion of oaths. The captain told me he had known the mate to throw a rouster that was lazy right overboard. "You've got to be rough with 'em," he continued. "They're a hard lot, and every man of 'em at the end of the trip will spend or gamble away the two dollars he's earned in the low dives of Vicksburg." 
Yet as far as their work was concerned he preferred them to whites; for none but negroes would contentedly "eat hardtack" and snatch such sleep as the exigencies allowed, "with a lump of coal for a pillow."

Toward evening we entered a twenty-mile bend that the river had deserted long before, and which had since been known as Lake Palmyra. But during this year's high water the river had torn through into the upper end of this ancient, stagnant channel, and a considerable portion of the current now went that way instead of by the cut-off. The river is always tearing away at the banks - an aggressive, unfeeling monster. It will wash off hundreds of acres of an exposed plantation in a single season. But when it washes on one side a sand bar starts opposite and soon rises above low water, begins to grow to willows, and at length builds up so that it can be cleared and cultivated. The stream progresses by many loops through the bottom lands, and often it cuts across the neck of the loops so that the valley is full of these abandoned channels; but the return of the stream to an old-time course is something unusual.

The weather had become threatening, and the sun, low in the west, had been gradually effaced in a gloom of thickening cloud. A rough wind arose, and there was a dash of rain. We had come to another stoppingplace, and pushed up into the willows skirting the bank until we could run our gang-plank to land near a store- 
82 Highways and Byways of the Mississippi Valley

house. While we were getting the goods to shore the clouds lifted in the west, and the sun shone out and sparkled on the waves and painted the misty east with a long streak of rainbow, and glorified the whole landscape with amber light. It was a scene enchanted.

Night came presently, but our journey continued with its frequent stops as before. One of our last calls was at a place where we went from the main channel back across country a mile or so. At first we followed a creek in the tall woods, and so narrow was the stream that we sometimes snapped off the branches on one side or the other. Then we came to more open country, where the brilliant eye of our searchlight revealed here and there a gaunt dead tree and a half-submerged barn, and in spots we could see the tops of fence posts. Occasionally we scraped bottom, and the mate stood near the prow dropping the lead and calling out, "Half twain three feet and a half - mark twain," etc.

It was a delicate piece of navigation, and not only was there danger of getting aground, or staving a hole on a snag, but the wheel might wind up a barbed wire fence which would be no less serious. However, we continued safely to a levee, where a bent little old man was waiting with a lantern, and walking about to keep warm in the clear chill night air. Not far away was a group of sheds, and the rest was woods. When we finished unlading, the bales and bags and boxes lay in half a dozen piles, covering the levee for some distance. 
Now the boat backed around, and picked a cautious passage to the main waterway.

About midnight we left Lake Palmyra by forcing our way against the tumultuous current pouring through the new crevasse, and then struggled on up-stream toward Vicksburg. Every one who could went to bed, but the berth assigned to me was in the same room with one of the drunken celebrators, and I preferred to let him have the entire space. In the first gray of the morning we arrived at Vicksburg; and though the trip was not all pleasure, I disembarked pretty well satisfied with its varied sights and experiences.

Note. - Vicksburg, by reason of the part it played in the Civil War, is one of the best-known and most interesting towns in the South. The battle-field is a national park. It covers a wide area, and for most persons the best way to see it is by driving. The town itself is remarkably picturesque, and one ought to do a good deal of rambling on foot to really appreciate the exhilarating changes of view, and the odd environment of some of the humbler habitations. Vicksburg is an admirable place from which to make a river trip. Few people would however enjoy being on a Mississippi steamboat more than a day, as the lower river is very monotonous. My experience would indicate that it is desirable to carry along something to eat when making a trip on a local steamer, for the food that will be furnished is likely to be very bad. In Vicksburg, as in nearly all Southern cities, only the best hotels are really satisfactory. 


\section{V \\ COTTON PATCH LIFE IN TENNESSEE}

TWAS only a short distance from Memphis, yet the region was almost as raw and rustic as if there had not been a large town within a hundred miles. To be sure great fields of corn and cotton were numerous; but I did not have to go far to strike the forest, and only a few decades have passed since the woodland was nearly omnipresent. The trees have been laid low to make fence rails and railroad ties, and to supply fuel for the old, wood-burning locomotives. Much of what was cut was ruthlessly wasted or sold for a song. "If the timber was standing now that was hyar twenty years ago," said one man, "we'd all make our fortunes handling it. Why, I've chopped down a coon tree and let it lie and rot that'd be worth forty dollars to-day."

The spring was backward, but the corn had been planted and was beginning to come up, and the cotton fields had been ploughed and ridged and much of the seed was in. On my first day, work was pretty much at a standstill, for a heavy rain the previous night had converted the fields into mud and bog. 


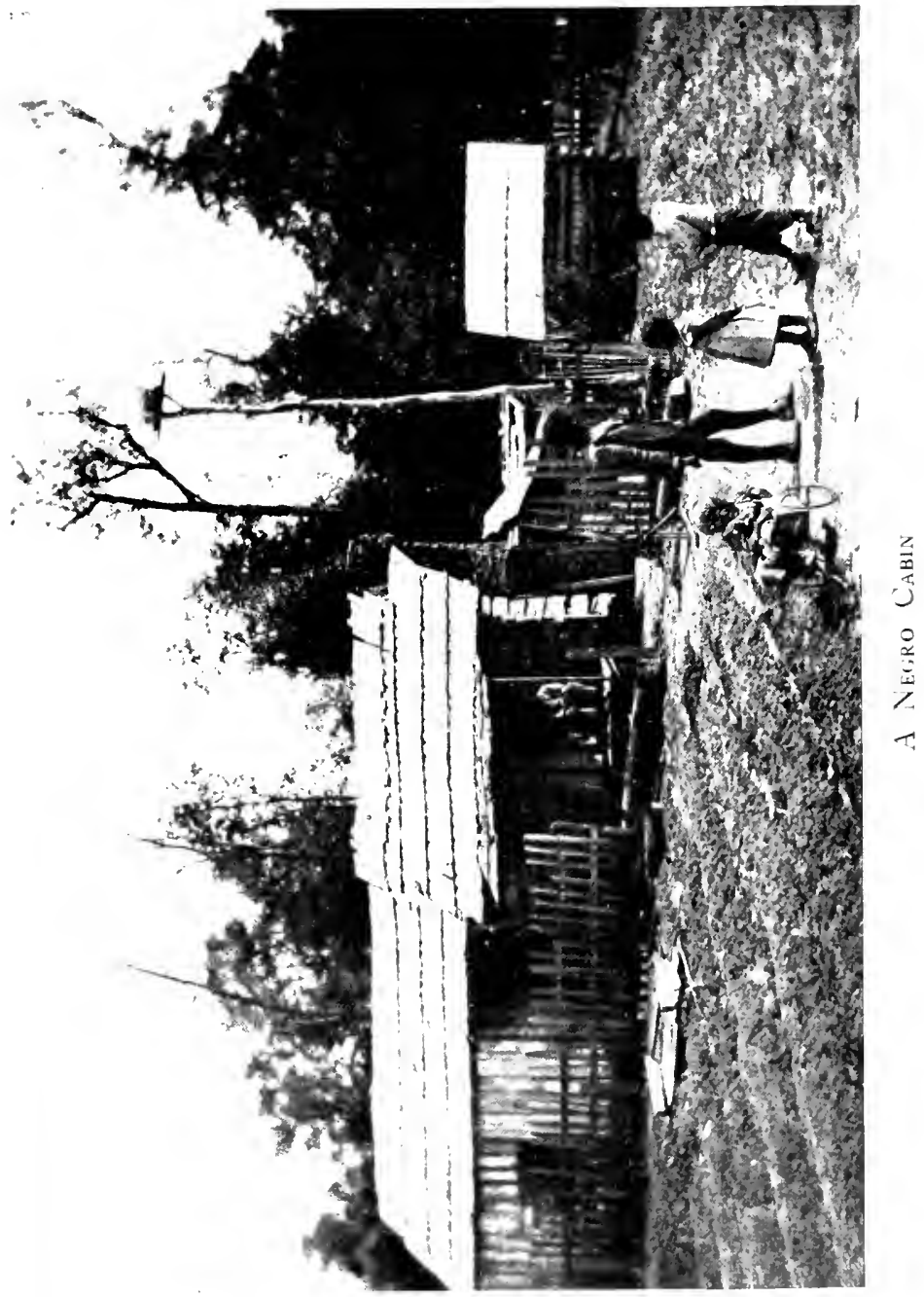





\section{Cotton Patch Life in Tennessee}

I started out for a ramble, and as long as I kept to the "pike" the travelling was fairly good; but as soon as I turned off on to a dirt road I was in sticky red clay, and had to pick my route with caution. There were more blacks than whites in this region, and the country was dotted over with their cabins. Many of the huts were made of logs, and they were all primitive. Some were so rudely constructed, and so open to the onsets of the storms, you wondered how they could be used for dwellings. The old lanes along which these homes were scattered were very wild and picturesque. There were stumps in them and occasional large trees, while along the fences grew briers and bushes. Frequently they were hardly more than a cart track wide, and were so rough and rutted as to be practically impassable for a Christian vehicle. In explanation of the badness of these byways, I was told that only negroes lived along them; and that therefore the local authorities never troubled themselves to "work" the roads. "Dey think anything will do fo' colored folks," was one negro's comment.

A rural delivery route ran through the district, and nearly every dwelling had its metal box set out by the roadside on a post. The white people owned their boxes at a cost of a dollar and thirty cents; but they told me that the negroes mostly rented theirs from a Memphis daily newspaper, and paid sixty-five cents a month for box and paper. A representative of the paper 
86 Highways and Byways of the Mississippi Valley

had explained to the negroes that they could not have boxes except on these conditions, and that if they were without a box they could only get their mail by going to Memphis for it. Many of them did not want the paper and could not afford the expense, but they were too inexperienced to comprehend the swindle or to know what to do about it. The colored families are apt to take a religious weekly, and every negro has thoughts and opinions on the topics of the time, especially on those that affect his own race; but, as one of them said, "Hit doan' do to talk much or we git into a heap er trouble. We low-born, an' the white folks are not likin' us to say anything."

The commonest type of negro home in the neighborhood was a long, single-story structure, with a kitchen at one end and sleeping apartments at the other, and an open passage-way between, known as "the entry." This entry served to separate the heated kitchen from the rest of the dwelling, and was a combination of porch, shed, and open-sided room for work and loitering. Its walls and roof made a handy hanging-place for all sorts of articles. The chimneys were outside at the ends of the house. They were usually of wooden slats thickly bedaubed with a mixture of clay and dry grass. "De clay an' grass chimney ain' ve'y endurable," I was informed, "an' in about fo' years dey have to be built over."

Toward noon I passed through a long stretch of 


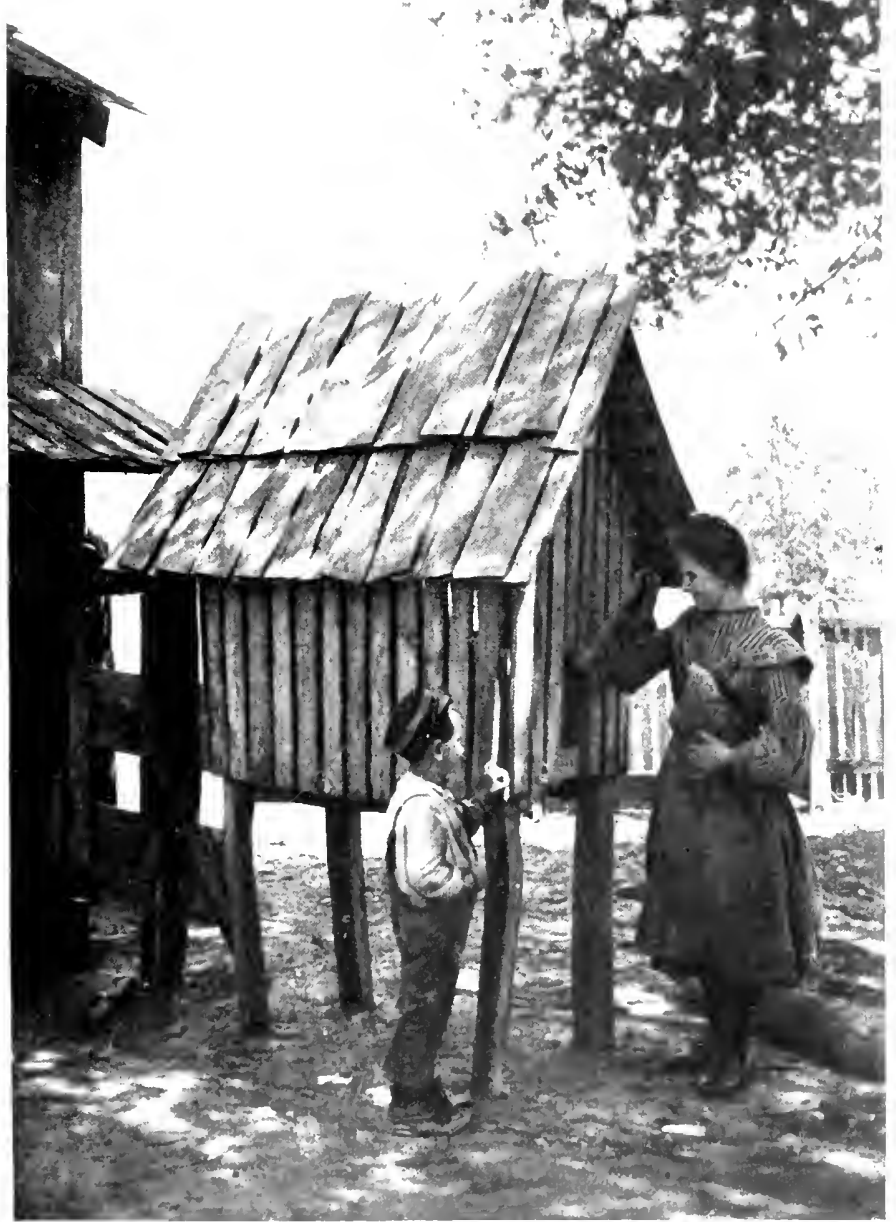

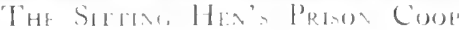



woodland. Off among the trees I could hear the dingdong of cowbells, the cooing of turtle-doves, the drumbeat of the "peckerwoods," and the trilling and twittering and whistling of a multitude of other birds. The wind rustled softly through the new foliage and the air was permeated with the odors of spring. Here and there were dashes of dogwood bloom, and patches of May-apple were coming into flower on the ground. I stopped for dinner at a farmhouse. The place was a half-wild sort of a ranch, the house badly out of repair, and in the home yard roamed numbers of turkeys, ducks, hens, goats, and hogs. Two of the older girls had been busy that morning picking up the dry last year's stalks in the corn field and piling them to burn. One of the boys, about ten years old, had been ploughing with a mule.

We ate in the hot and grimy kitchen. Pork and mustard greens, corn-bread and coffee, were chief on the bill of fare. The farmer suggested I might prefer milk instead of coffee, and he poured a glass for me; but one taste was enough. The children of the family drank it freely, and the man also took a tumblerful. As he finished it he casually remarked that the milk was a little sour. I wondered that he said "a little," for it was half curdled.

He entertained me very handsomely and exemplified what he called "the old-fashioned Southern hospitality," that was "glad to see you come, and sorry to 
see you go." He observed further, that "Befo' the war nothing gave a man more pleasure than to do honor to his guest. You were treated with special respect, even at the hotels. Why, I used to know a landlord who, after a man registered, always wrote in front of the signature 'Capt.,' 'Maj.,' or 'Col.,' so that no one stopping at his hotel failed to have a military title. $\mathrm{He}$ was a genuine polished old-style gentleman, and his guests was all treated like they, was persons of distinction."

My host said he was going fishing later in the day. "This is just the right time of year for it," he declared.

"r Dogwood white

Fisher's delight,'

you know. Every old colored woman gets her hook and line ready when the dogwood blossoms, and so do all the rest of us."

By night, when I returned to my boarding-place, the weather had turned cold, and the next day was so chilly and clouded I stayed indoors most of the time. A rude wind buffeted the trees and soughed wearily about the house, and I sat beside the kitchen fireplace to enjoy the grateful heat of the brisk fire that was kept burning there. The gloomy skies and the bleak and boisterous wind seemed to put my landlady in a mood for telling ghost stories. "The first thing I remember of my childhood," said she, "is of sitting out on the porch of a 


\section{Cotton Patch Life in Tennessee}

moonlight night and hearing the darkies tell about the witches. When I went to bed I was so scared thinking a witch might come through the keyhole, I jus' couldn't sleep.

"The niggers have a lot of queer ways. They take poisonous snakes' heads and pound 'em up with other poisonous things to put in hoodoo bags; and then they hide the bags under the doorstep, or in the bed of the person they want to harm. Once I was sick for a long time and no one could make out what the trouble was. At last the house burned and most everything in it; but we saved my feather bed, and I tore it up to make pillows. Inside I found a hoodoo ring made of feathers twisted into a band or ring fifteen inches across, and tied to it was a hundred or more little bags. I put it in the fire, and after that I got well. I 'spose I'd been inhalin' the poison.

"When you was in Memphis did you see Brinkley Hall? I went to school there. Well, one night my room-mate and me was sitting together with a lighted lamp on our table. Suddenly some one blew out the light, and the lamp chimney went on the floor and was smashed. We was all in darkness, and we ran to the door. It was a door that never would close tight; but it was tight shut now and we couldn't get out. We heard some one walking in the room over the broken glass of the lamp chimney, and we began to scream. The girls in the rooms near us came to our door, and 
90 Highways and Byways of the Mississippi Valley

we told them what had happened, and how we couldn't get out. They laughed at us, but when they listened and heard the footsteps they went to shrieking. That brought the principal running up the stairs, and he opened the door; but there was nothing to see only some broken glass on the floor and us two girls limp with fright.

"After that all sorts of things happened at the school. The girls used to hear the noise of water falling on the floor, and bells would ring with no one ringing them; and there was one scholar named Flora Robinson who would go into a trance, and see a little girl in a pale pink dress who kept following her. Once the little girl had her take a pencil and write, and the writing said that if Flora's folks would dig in a certain place they'd find jars with papers in 'em showing that Brinkley Hall belonged to the Robinsons. So her folks got some men to dig in that place, and a few feet down they came to a brick wall, and they tore that to pieces and found three glass jars, and they could see money and papers inside. They decided to let the jars stay right there till next day when they would open 'em before proper authorities. A man stood guard; but during the night he was knocked on the head, and the jars was stolen. So much had happened that the school broke up, and Brinkley Hall with its forty rooms is vacant yet.

"Another strange thing in my own experience happened after my husband died. He was very fond of 
. 


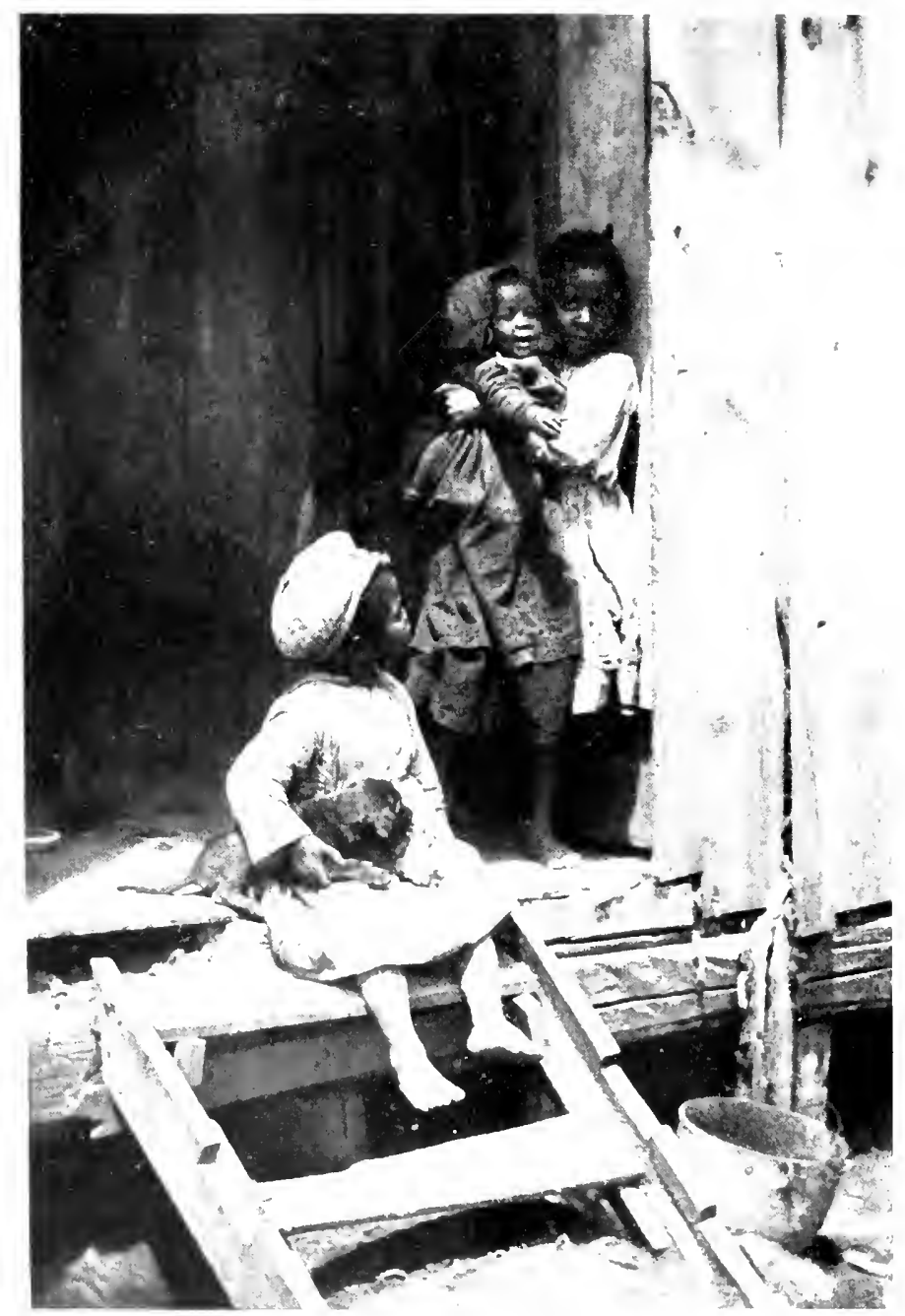

ON THE PORCH 
music, and in his last sickness he said if he could return to earth he would make his presence known by playing the piano. One day just at supper time, after he'd been dead about two weeks, I heard the piano play. All the children heard it, too, and we jumped up from the table, scared to death. I said I never would want to use that piano again, and I sent it to Memphis to be sold."

My landlady in concluding urged me to call on a negro family by the name of Houston that lived next door and ask them what they knew about witches and other occult things. Their house was in a yard full of trees, and its aspect was rather pleasant from a distance, but when I got a close view I found it was shabby and decrepit. I was welcomed into the kitchen, a dismal place that gloomy day in spite of the flames flickering in the fireplace. The floor sagged dubiously, the ceiling was brown with smoke, and panes were missing from the windows, and the holes stuffed with rags. Newspapers were pasted in a queer motley over the walls. The room had two beds. On one of them lay a gun. A sick girl was in the other, and the rest of the family sat in a circle at the borders of the rough, deepworn hearth doing very little except to spit into the fire at frequent intervals. Mrs. Houston and her two daughters each had a wad of snuff inside of her under lip. My landlady had mentioned that a pedler of spectacles had recently been along. "He had two qualities," said she, "one for white folks at a dollar and a half, and one 
92 Highways and Byways of the Mississippi Valley

for darkies, with brass bows, at seventy-five cents. Houston bought a pair for himself, and a pair for the old woman. He wanted his oldest girl to have a pair, too, because they were fashionable, but she wouldn't."

Sure enough, when I entered the kitchen, Mr. Houston went to the window-sill and got hisspectacles, and handed his wife hers, and they both put them on. We were soon talking about the mysteries, and Mr. Houston said: "De witches ride our horses at night. In de mornin' we'll find der manes and tails full of witches stirrups - de ha'r all twisted and tangled up. It couldn't twis' itself up dataway, an' yo' cain't pick de ha'r straight in an hour. You have to cut it. You can lock yo' horses up an' tie 'em tight as yo' please; but it make no dif'runce, de witches git 'em an' use 'em jus' de same. Sometimes, too, de witches come in de house when you asleep an' ride you, an' you wake up all tired an' lame."

"I doan' min' de witches so much as de conjurations," remarked Mrs. Houston.

"Well," said the man, "if yo' find a conjure thing, all yo' got to do is to put some silver money in yo' shoes, an' you c'n walk over it widout gittin' any harm."

"But it ain' often yo' find it befo' hand," she objected, "an' I doan' want to keep money in my shoes all de time."

"My oldes' girl, Em'line, was tricked once," the man went on. "She'd have a pain in her breast, an' nex' minute de pain would be in her side, an' den in her 
back - de pain keep movin' aroun' all over her an' was worryin' her to death. We went after a medical doctor, and when he see her he turn white an' scratch his haid an' look like he scared. He did de bes' he could fo' her, but ev'y bit er de medicine what he give her she throwed up. We tried some mo' doctors, an' dey ev'y one give her a round er medicine; but none of 'em couldn't help her. She had spells like she was dyin' an' got black under her eyes an' round her lips, an' she said it no use to sen' fo' any one else. But we went an' got a hoodoo doctor from Memphis. Soon as he come he say to her, 'Who you shuck hands wid?' "She tol' him she ain't shuck hands wid nobody; but he say some one had hol' er her hand shore, an' he describe de man, an' she know who de man is. He a feller what been wantin' to marry her. We try to raise our children nice an' 'spectable, an' we want 'em to keep de bes' company dar is, an' dat feller too no account. So she wouldn't have him. She say she ain't shuck hands wid him; but one day she climbin' up a bank, an' dat man had caught her by de arm an' holp her up, an' no sooner did he do dat dan she fin' herse'f havin' de trembles. De hoodoo doctor he listen an' lif' his eyebrows; but he 'pear not to be sati'fied yit. He look aroun,' an' he say, 'Dar somethin' bad in dis hyar house;' an' he ask Em'line, 'Whar dose pillows on yo' bed been to?'

“Den he took 'em an' rip 'em open, an' dar was a 


\section{Highways and Byways of the Mississippi Valley}

conjure thing big as yo' fis' in each one. It was a piece er cloth wid wax on both sides, an' all kind er feathers quirled aroun' and aroun' in de wax. De hoodoo doctor pass one to me, but when I took it in my han' a cramp run plumb up in my shoulder. I couldn't hol' it. Nex' thing, de doctor look at de bottles er medicine on de table, an' set 'em all aside, an' tol' us not to use 'em no mo'. Den he give Em'line a little shot er quicksilver an' she swallow it an' was cured. I done heard that quicksilver is death fo' a well person to take any of it; but if yo' been conjured it ketch de pizen an' doan' hurt yo' none."

"Yo' c'n tell whether yo' been tricked," said Mrs. Houston, "by takin' a piece er silver money an' sleepin' wid it in yo' mouth. If yo' been conjured, de silver, in de mornin', be jus' as black as a coal wid spots er yaller like copper on it."

"De hoodoo doctor charge ten dollars fo' what he done," Mr. Houston resumed. "Dat a heap to pay, an' yit, if I was took sick bad, I shore would send fo' him."

"De same feller what trick Em'line made de attemp' atterward to conjure de whole chu'ch," said Mrs. Houston.

"Yes," observed Mr. Houston, "I see him put a little mess under de chu'ch doorstep an' bury it. I didn't know certain what he doin', but I step aroun' it when I went in. Yuthers, dey step over it, an' dey git con- 
jured. Our preacher man, he git conjured, too, an' no sooner is he preachin' dan he make out like he mighty happy, an' he put his arms round de sisters an' hugged 'em. I reckon if he hadn't been wearin' a silver watch which kind er protect him, he'd been killed. My nephew was took sick at de same time right dar in meetin', an' I tol' him what de matter was. So he jump on a mule an' rode as fas' as he could to de doctor to git himself worked on. Atter meetin' I took a stick an' pull de conjure thing out from under de doorstep, an' de nex' Sunday we discuss de matter in de chu'ch to see what we better do about de feller; but he had skipped, an' he ain' been round hyar since."

"I mighty glad he gone, too," Mrs. Houston commented. "De way he done trick Em'line give me de worst scare I had since freedom. Yas, dat de bigges' shakeup I ever expe'ence, excep' in de war when dey had a battle near whar I lived. Oh, my Lord, how dey fought! We'd hear de guns a-firin' fast as dey could pop, an' once in a while a big cannon would bang. De Southern soldiers went marchin' past, back an' forth, an' dey go all through people's fields. Lord 'a' mercy! dey'd throw down de fences dat was in de way, an' make a wide dusty road right through de green fields. Den de Northern soldiers come, thousands an' millions of 'em, I reckon, an' dey took all our horses an' mules, an' all de hams out er our smoke-houses. Some er de white folks would hide der things, but de Northern 
96 Highways and Byways of the Mississippi Valley

soldiers would git hol' er de darkies an' threaten to kill 'em if dey didn't tell whar de things was. Dey begun to build forts, an' dey tell de planters to sen' der darkies to help. One mighty mean man said he wa'n't gwine have his darkies workin' fo' de North. So dey took his two sons an' put dem at diggin'. Dat make him think he made a mistake, an' he didn't was'e no time in bringin' de darkies to take his sons' place."

"I holped de Republican party build dem breastworks," declared Mr. Houston. "Dat de fust work I done fo' de Republican party. It wa'n't long befo' de Rebs had been run out from aroun' hyar. De cars kep' comin' all de time loaded inside an' outside wid Republican party soldiers, an' in der uniforms dey look jus' like bluebirds. Some colored men jine de Republican party army an' went to fight, an' dey want me go too; but I'd got a wife, an' I didn't want to be separate from her an' perhaps never see her again. Besides, I didn't know whether de North gwine beat, though it look mo' bad fo' de South all de time. Yit I kep' out er de army way to de end, becaze I reckoned if de Republican party win, I be free whedder I fight or not. If she git licked I better not be too much mix up in de rumpus."

Back of the village to the east was a wide expanse of corn and cotton fields extending over to some woods along a creek. Bordering the woods were frequent cabins, and these were connected with the village by irregular paths skirting the ditches and edges of the 


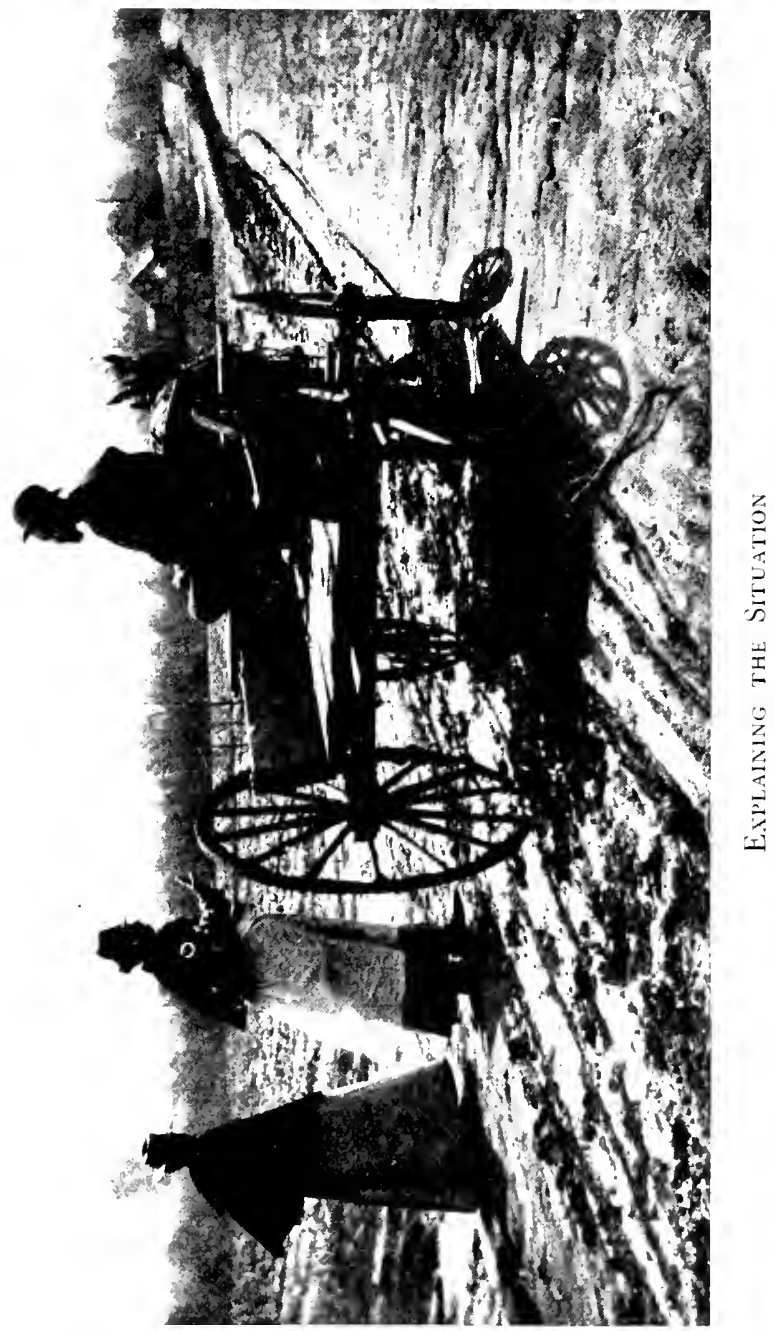



fields and occasionally taking a straight cut across the cultivated grounds. Most of this land rented for five dollars an acre. Corn and cotton were the chief crops, but some of it was planted to potatoes and pease. In good weather the region is very busy with men, women, and children intent on earning the money to pay the rent and get a living for themseves. They begin to put in the cotton seed when the scrub hickory buds; and a white man told me that negroes depended so much on nature thus to indicate the proper time, that "If the scrub hickory didn't never bud they wouldn't never expect to plant."

A month later the cotton is ready for its first "chopping" - that is, hoeing. They start picking in September, and money is then more plentiful than at any other season. Most of the negroes, in addition to caring for their own crops, do a good deal of picking for the whites. The pay is fifty to seventy-five cents a hundred, and the day's labor begins as soon as the dew dries and ends a half hour before sunset. "It's fun to any one to pick cotton," an old woman said to me. "I've picked over two hundred in a day many a time, and nursed my baby and milked my cow and cooked dinner fo' me an' my ole man an' three chillen. De men de bes' pickers. Some of 'em certainly can snatch it. De women gits tired in de back, an' de men dey hol' out longer. When dere's a prize offered I seen men pick much as four hundred pounds er dis yer big boll cotton in one day." 
98 Highways and Byways of the Mississippi Valley

The fields are at their whitest just after the first frosts. Then all the bolls open and the cotton patches look as if there had been a fall of snow. The frost also loosens the cotton and makes picking easy. The work goes on for many weeks, and there is some desultory gleaning all through the winter. One famous cotton picker is "Uncle Henry," reputed to be over a hundred years old. He never cuts his finger nails, because he wants them to grow long, so he can have their aid in getting the cotton quickly out of the bolls. I called on him one day at his house, and as I approached I heard him singing a curious negro hymn.

" A gospel hook got-a-hung to my heart, Eli shoutin' in de heaven, 'Good Lord!

Good Lord! Good Lord!'

Eli shoutin' in de heaven, 'Good Lord!' "'

His home was on the edge of the woods, a whitewashed $\log$ dwelling with a huddle of little outbuildings and fenced enclosures roundabout. Uncle Henry was sitting by the kitchen fire entertaining several grandchildren. The grizzled old negro looked to be about fourscore; but he had no doubt he was entitled to thirty years more, and said there were lots of colored people one hundred and twenty and one hundred and twenty-five years of age. He remembered distinctly the "falling of the stars" in 1833 , and any negro whose memory has that span is a patriarch of his race. Aside from the war, that is the greatest 
event of modern times in the chronicles of the colored folks.

"I was about ten years ole, I reckon," said Uncle Henry, "and I was out playin' hide and coop wid a parcel er white boys, an' we thought it was a snowstorm at de start. Den, de fust news I knew my mammy an' missis was a-hollerin' an' cryin', 'Lord have mercy! Lord have mercy!' an' sayin' it was de end er de worl'. My missis made noise enough, I can tell yo' dat. I never heared such a voice as dat woman had. One er our men was name Dave Tucker, an' he was de only man on de place what could hive bees. When de bees swarmed he bleeged to come, an' my ole missis could holler an' call him from five miles away.

“Dat night I speakin' about it appear like ev'y star in de sky was a-fallin'. Some er de boys try to cotch 'em in der hats, but de stars go out befo' dey git to de groun'. Dey lit up de whole earth, an' as dey fell dey made a sissin' soun' like de soun' er draps er water thrown on a hot skillet. My oldes' brudder, he'd been out 'mongst de gals dat night, an' he was on his journey home when he heard de roarin' er de stars a-fallin', an' he thought de whole elements was burnin' an' de judgment come. He reckoned his time was out, an' de got down den an' dar on his knees an' he prayed, 'O Lord, come quickly, come quickly, I greatly need yo' !'

"Dem dat hadn't never prayed in der lives prayed a li'l' bit dat night, an' I hear tell er one man - an' 
I00 Highways and Byways of the Mississippi Valley

he was a ve'y ole man too - he ain' been use to prayin', an' he try to say de Lord's Prayer; but when he git to, 'Thy kingdom come, thy will be done,' he kind er mixed, an' he say instead, 'Lord, kick 'em as dey come!' Yas, it scare us all, an' in less'n two weeks ev'ybody, white an' black, got religion. Dar was mo' religion dan enough."

When I left Uncle Henry one of his grandsons became my guide on the uncertain paths that linked cabin to cabin and connected them with the village. He told me about a gun he had, and how he had shot rabbits and tried to shoot ducks.

"What's that bird we hear in the tall trees just ahead?" I interrupted.

“Dat's a kind er a li'l' ole bird call' a wren," was the reply.

Then he pointed out a redbird and some "jay birds," and said, "De redbird de prettiest bird we got. Dar's lots er birds hyar - peckerwoods an' sapsuckers an' yallerhammers an' robins; an' dar's de rain crows what set up in de trees an' holler when it's fixin' for to rain; an' a li'l' ole speckle bird call a thrush. Some er de birds are good to eat, an' in de winter time I knock 'em down wid a stick. Dey roun' stumps atter something to feed on, an' it so col' dey won't hardly fly. Yo' be astonish' how col' it is hyar sometimes; but in summer, it often so hot we cain't scarcely stay in our clothes. We gwine along de bottoms near de crick now. Yo' 
hear all dat hollerin' over dar? Dat de spring frogs. Dey a li'l' muddy color frog no bigger dan de end er my thumb. Dey de firs' frog in de spring. De toad frog an' de bullfrog doan' come until it git right warm."

The boy was surprisingly keen in his knowledge of the little creatures of the fields and woods. He was himself a child of nature, a companion of the wild, whose world was narrow, but not by any means uninteresting. Nor was he at all unusual. Most of the blacks are well versed in this sort of lore, and in a simple way the field, the forest, and the air serve them for the information and entertainment which most of us go to books to gain.

The labor of the families who depended on the cotton patches for a living did not seem to me to yield very satisfactory returns. Few are able to attain a safe prosperity, and poverty stalks along behind most, ever threatening to drag them off their little holdings. Such conditions were often revealed to me by my chance acquaintances. For instance, I one day stopped a negro who was driving a farm cart through the spring mud of the highway and asked directions. While we were talking a colored woman came plodding along and spoke to the man. "Hit been a long time since I seen you, Brother Bealy,” said she. "How yo' gittin' on ?" "Well," he replied, "I had a hard expe'ence dis las' winter wid de rheumatism; but hit has let up on me some now." 
102 Highways and Byways of the Mississippi Valley

"Yo' luck sholy have been bad, Brother Bealy," said the woman sympathetically.

"I done met some heavy ole jars, Sister Larkin," he admitted. "Las' year de secon' time I been sol' out on account er mortgages. Hit quite a th'owback for me. I got six chillen an' a wife a-swingin' on top er me, an' hit no easy matter to pay my rent and all de yuther expenses."

"Yas, to take keer er yo' fambly, yo' oblige to hit hard an' often," was the woman's comment; "but if yo' keep up heart, de Lord, He boun' to pull you through."

The man removed his hat and rubbed his head thoughtfully. "I gwine to stick to my work long as I c'n move," he said; "and I'm gwine to pay all my honest debts from a nickel up. God knows I am."

"Dat right, Brother," the woman responded heartily, “an' doan' let any mo' mortgage be put on yo'. Dar's a heap er people you an' me have knowed roun' hyar have got in debt till dey owed two or three hundred dollars, an' den dey so discourage dey lef' de country. Dese lenders keep puttin' on per cent and per cent, an' hit jus' nacherly ruins dem dey lends to."

"Yes," agreed the man, "fifteen per cent and ten per cent and de principal, too, been mo' dan a good many could stan' under. Dey done all dey could, an' at las' dey give up ev'ything but de shirt on der back, an' some of 'em pull dat off an' say, 'Hyar, take dat too.' " 
The man gathered up his reins preparing to drive on. "We been havin' pretty tolerable rough weather," said the woman.

"We certain have," was the man's response, "an' dat big win' las' night done shook my ole shack till I thought de house blow to pieces."

"Hit took off de las' er de apple bloom," the woman added, looking off over the landscape. "De trees look now like we have apples to bet on hyar mont' atter next."

“What yo' hear from yo' son in Texas, Sister Larkin ?" asked the man.

"I plumb worried about him," she replied. "De las' news I heard he got de terrified fever."

They discussed this typhoid (?) fever, and then the man resumed his journey. I went on in company with the woman. She called my attention to the poor repair of the fences along the way, and told about "a no fence law" passed a few years before which obliged every one to keep their stock from running at large. Previously the crops had to be fenced, and the cattle and hogs were turned loose and went where they chose, and they "pretty nigh picked up der own livin'." But this wicked and incomprehensible law made it necessary to take care of them and feed them, and that didn't pay.

In concluding her remarks the woman philosophized thus: "Times have been; times will be; times wear 
IO4 Highways and Byways of the Mississippi Valley

out same like ev'ything else. De ways dey use to do ain' like de ways dey do now. Dese days, if yo' doan' take keer er yo' cattle dey're ketched an' yo' have to pay three or fo' dollars to git 'em ag'in."

The black cotton workers have their troubles, but they have their pleasures, too; and one of the chief of these pleasures is a debating society. This met every Saturday night in a spare room of a certain log cabin. The apartment was fitted up with a few benches and some boards laid on blocks, and it was pretty sure to be packed full. The discussions were very earnest and aroused much interest. "Las' Saturday," said a member of the society, "de question was, "Which is de bes' beneficial, education or money?' Three fighted fo' education and three fighted fo' money, and education whooped. Anudder time we debate, 'Which has de deepes' effec' on a person's min', what he see, or what he hear?' Nex' time de question gwine be, 'Which done de mos' fo' de people - war or de ministry ?"”

The negroes found delight in exercising their intellects at the debating society; but in the case of the whites, nothing appealed quite so strongly as the pleasure of satiating their stomachs at a barbecue. "Our barbecues are the biggest thing yet," I was told. "We most always have a neighborhood barbecue in August or September, and we have 'em at election speakin's, and Sunday-school picnics. When I was a boy we had one on the Fourth o' July. Everybody was bound to get 
done cultivating his corn and cotton by then so as to be ready to celebrate. Yes, you'd drive your mule till it didn't have any tail to get done by the Fourth. The way we fix for a barbecue is to begin to get ready the day befo'. The meat is roastin' all night. We have plenty of different meats - shoat, calf, kid, and goat, and we roast the whole animals. A trench is dug, and oak bark coals put in. Then sticks are laid across for the meat to rest on. Some white man has charge, but the niggers keep the fires goin' an' do the basting and the rough work.

"The next day everybody comes. There's a detail to do the carving, and we all step up and get what we want and go and sit down by some tree to eat it. Of course there's potatoes and cornmeal lightbread, and pickles and cake, and there's ice cream, and there's pure, genuine, strong coffee that the old ladies make, in abundance. Then there's fried chicken, if any one is fastidious enough to want it, and some enterprising fellow is likely to bring half a dozen bottles of beer and invite his special friends out to his buggy to drink it. But the best thing to my thinkin' is the shoat. A man hasn't got any part in the resurrection until he's eaten barbecued shoat."

The narrator's enthusiasm was quite superlative, and I have no doubt that the barbecues for the whites and the debating society for the blacks do much to brighten an otherwise somewhat sober existence. 
I06 Highways and Byways of the Mississippi Valley

Note. - To see something of rustic Tennessee with ease and comfort it is perhaps bcst to take a good-sized town as a base where one can live at a first-class hotel. Rations and housing for the traveller out in the country have a somewhat doubtful character. But from any large town one can go by train, or drive, and soon get into the cotton country and observe the people's homes and their work. Interest largely centres in the life one sees, for the landscape of the cotton regions is apt to be monotonous and devoid of charm. 


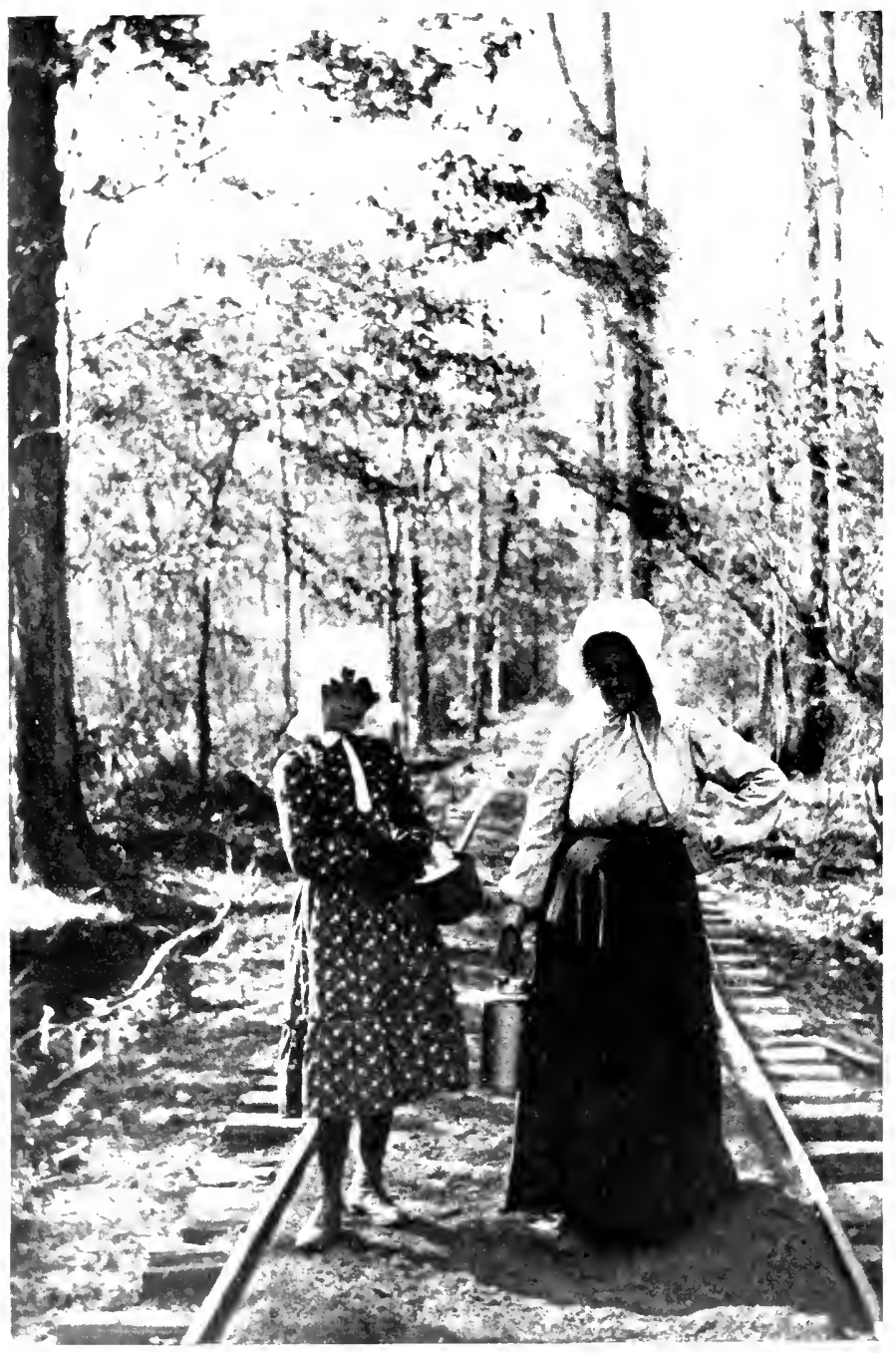

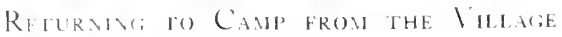




\section{VI}

TRAVELLING IN ARKANSAW

7 HERE is no "Arkansas" in the nomenclature of the lower Mississippi valley - at least I never 1 heard it until I was as far north as St. Louis. However, I understand that the name "Arkansaw" is not universally acceptable to the inhabitants of the state; and at one time the commonwealth's two senators had such decided and opposing preferences on this subject that in Congress one was always addressed as "the gentleman from Arkansas" and the other as "the gentleman from Arkansaw."

Among the state's immediate neighbors it is customary to speak slightingly of conditions across the line, and you would gather the impression that life and manners there were rather cruder than anywhere else in the great valley. The outside dwellers take particular pleasure in repeating a curious legend known as "The Arkansaw Traveller." This tale has been a favorite for more than half a century, and, told properly, it has a musical accompaniment. Formerly, whenever there was a social gathering that included a man with a violin, this man was sure to be asked to play "The 
I08 Highways and Byways of the Mississippi Valley

Arkansaw Traveller"; and the listeners took equal delight in the cheery jig of the music and in the medley of jokes that went with it.

"Well," says the musician, "thar was an old feller in Arkansaw who was settin' out in front of his cabin on a stool one evenin'. He had his fiddle an' was playin' away on this tune." (Plays, but breaks short off in the middle.)

"'Bout that time along comes a traveller ridin' on his horse, an' he stops an' says, 'Hello!'

"“'Hello yourself,' says the man.

"'Can you give me a night's lodging?' says the traveller.

"The man allowed he couldn't nohow. 'We got no room, stranger,' he says.

"“Can't you make room?' the traveller asks.

“" No, sir,' says the man. 'It might rain.'

"“And what if it does rain?' says the traveller.

"'Why,' the man says, 'thar's only one dry spot in the house, and me 'n' Sal sleeps on that.'

"Then he begun sawin' away on his fiddle again." (Plays, but stops suddenly, as before.)

"Everything was terrible tumbledown, and the traveller see how leaky the roof was, and he says: 'Why don't you mend your roof?'

“" 'When it's pleasant I don't need to,' says the man; 'and when it rains I can't."' (Plays the tune again half way through and stops.) 
“" What makes your corn so yaller?' says the traveller, lookin' at the field over the fence.

“' Oh, we plant the yaller kind, hyar,' says the man." (Plays the half tune.)

“'How do your potatoes turn out this season?' asks the traveller.

“'They don't turn out at all,' says the man. 'We have to dig 'em.'”, (Plays.)

"“Whar does this road go to?' asks the traveller.

“'It don't go nowhar, stranger,' the man says. 'I been hyar an all-fired long time, and that road has always stayed right whar it's at.", (Plays.)

"'How many years have you lived in this country?" says the traveller.

" "Do you see that mountain over yender?' the man says. "Well, that was thar when I come hyar.", (Plays.)

"'What are you playin' that tune so often for ?' says the stranger.

“' Only heard it yisterday,' says the man. 'I'm afraid I'll forgit it.'

"'Why don't you play the rest of it?' the traveller says.

"'That part is good enough for me,' says the man; 'and besides, that's all I know.'

"'Give me the fiddle,' says the traveller.

"The man handed it to him, and the stranger played the whole tune like this." (Plays.) 
I IO Highways and Byways of the Mississippi Valley

"Soon as he begun playin' the second part the man jumped up and started to dance, and at the end of the tune, he says, 'Walk in, stranger, and stay as long as you please. If it rains you c'n sleep on the dry spot. Zeke!' he says to his boy, 'put this man's horse in the corncrib and stop the door with a haystack. Sal, take the grubbin' hoe and go dig some sassafras to make tea for the stranger.'

I found plenty of people who could repeat the jokes; but it was not so easy to discover a fiddler. At last, in one of the river towns, a waiter at my hotel gave me the address of a colored man by the name of Jack Hamilton who he said could play the tune. The address took me to a dingy corner saloon frequented wholly by negroes. Jack was there, and so was his partner Ed Smith, sitting together at one side of the dark, grimy, and odorous room. Jack was black as a coal. Ed was a mulatto, with handsome features and a touch of refinement and poetry about his slender figure that seemed incongruous in such a place. He played his violin with great facility and charm, and Jack's accompaniment on the guitar was spirited and pleasing. Jack sat stiff and upright with his brows twisted, and a far-away look in his eyes, and a cigar stump cocked up in the corner of his mouth. Some of the hangerson of the saloon gathered about to listen to the music. Others continued with their drinking and noisy talking. As to the melody, it was a quick reel 
tune, lively and attractive, and I did not wonder at its popularity.

One of my first stops in Arkansaw was at a sawmill village in the woods. The forest was being worked up into barrel material, and all day the place resounded with the buzz and whir of machinery and the shrill, ravenous notes of the saws. It was a strange little hamlet that gathered about the mill - a settlement of forest-wreckers, devoid of the least touch of beauty. The land was low and level, and puddles and pools and shallow ponds abounded, but these would gradually dry away as the season advanced. The schoolhouse was in the middle of one of the larger ponds, and several lines of boards were laid along on blocks and stumps to the building. These improvised bridges were common all through the village. Everywhere was scattered rubbish from the mill - sawdust and slabs and fragments of boards. The houses were small and rude, and looked like temporary shelters, which perhaps they were; for when the mill has finished its devastation, and its devouring saws are silent, most of the population will move away.

On the outskirts of the hamlet were several little farms carved out of the wilderness. Just how to get to them I was in doubt. I went through a village dooryard, and climbed the back fence, crossed a pasture, climbed another fence, and found myself in a slough where water so abounded that I was tempted to retreat. But the ground was strewn with a chaotic mass of brush 


\section{2 Highways and Byways of the Mississippi Valley}

and limbs left behind by the choppers, and this helped me over the water shallows and the mud to a big corn field amidst a scattering of girdled trees. The field was boggy, too, and it was bristled everywhere with withered last-year's stalks so that the walking was far from easy. However, I continued to pick a way to the farther side, where I encountered a man pulling up stalks and gathering up branches fallen from the girdled trees. He was piling these in heaps and burning them. "I ain't gittin' along very well this year," he said. "It's been a wet spring, and every time I think o' startin' to work it rains. I have to wear my gum boots constant."

He did not own the land, and one-third of the corn he raised and one-fourth of the cotton went to the landlord for rent. The soil was difficult to cultivate, it was so heavy, and the crops were uncertain. "The bugs and worms git after the cotton," he explained. "Last year we had a bug what we call the sharpshooter. It come when the bolls was just formin' an' blasted 'em so they dried up an' stuck thar hard an' fast."

The man showed me a better route back than the one by which I had come. "Do you see that roof off thar?" he said. "That's on the main road. I'll put you on a path and all you need do is to foller it. The building you see the roof of pretends to be a grocery; but it's 'way outside the village, and thar's mighty few goods on its shelves. I reckon it's a blind tiger. I've seen men goin' to it, and I've seen 'em comin' away, and 



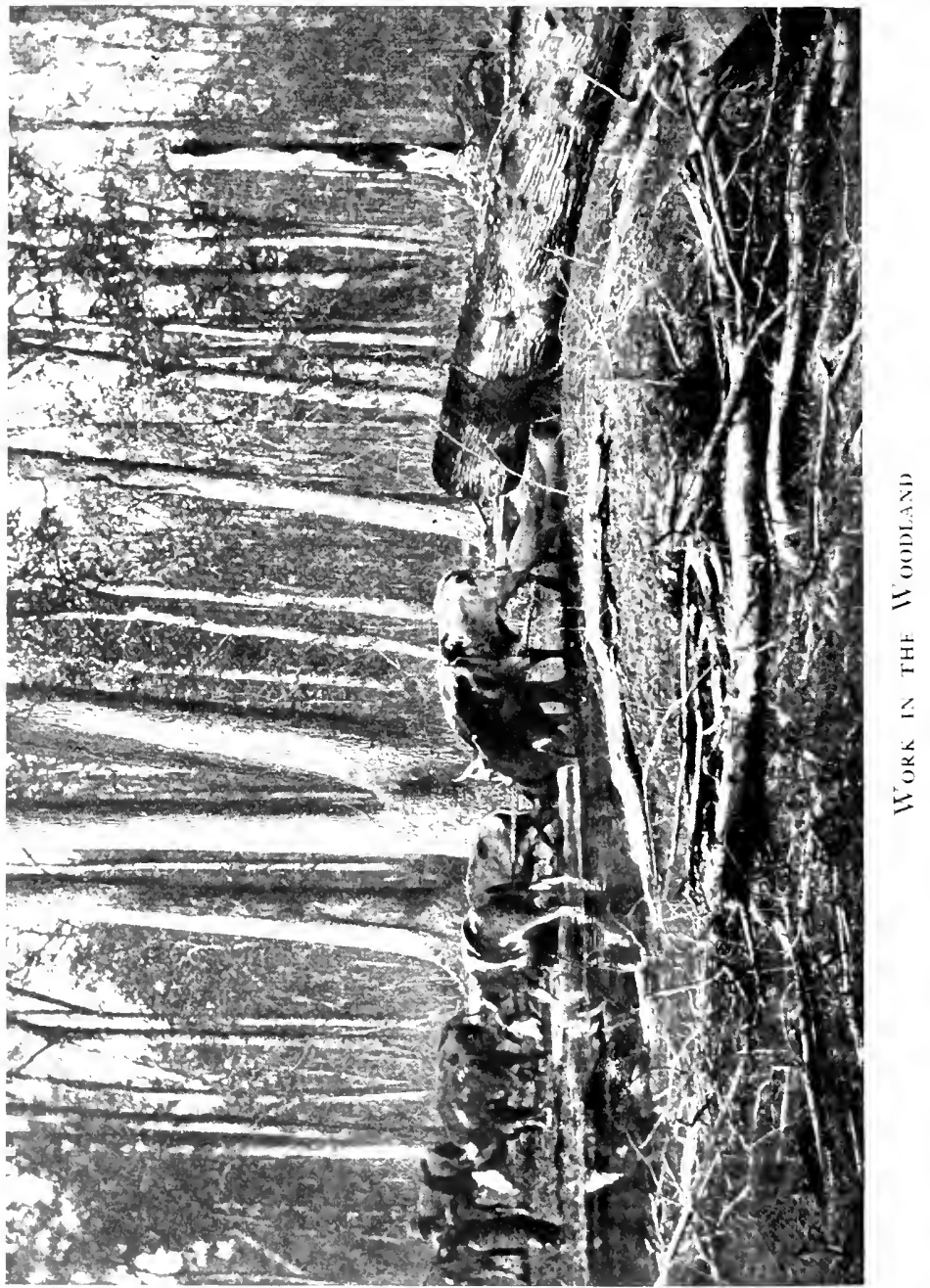


they walk a great deal straighter goin' than they do comin'.'

When I reached the main road I considered continuing by it farther out into the country; but it was too deeply rutted and watery to encourage travel, and I betook myself instead to a tramway that went off three miles into the woods, to where trees were being felled for the mill. Along this track stout little cars went back and forth, two at a time, drawn by a plodding mule. The day was quiet and sultry, the sunlight flickered through the foliage, the birds sang, the woodpeckers clattered on the dead trees, and once I saw a king-snake basking in the warmth on an exposed bank. This snake was the most gorgeous monster I have ever beheld - its entire length of fully a yard being ringed with narrow bands of brilliant red, black, and light yellow.

Near the end of the track was a choppers' settlement, consisting of a score of structures loosely grouped among the trees. They had floors and sides of boards; but the roofs were of canvas, put up tent fashion. Such construction made it a simple matter to pull them to pieces and move them when the vicinity had been chopped over. The moving of the homes to be nearer the work was necessary every six or seven months. The woodsmen had their wives and children with them; and there were bevies of pigs and chickens wandering about, so that the village was quite domestic. 
114 Highways and Byways of the Mississippi Valley

The work that interested me most was the herculean task of dragging the logs from where they had been felled to loading-places beside the track. This was done by ox power, four yokes to a team, and even then the bigger logs were almost beyond the oxen's strength amid the mud and stumps and brush. The creatures seemed very willing and patient and intelligent; yet the drivers were always pouring forth a torrent of oaths and abuse, and cracking the long lashes of their savage whips with reports like pistol shots. Perhaps the string of beasts would come to a full stop in some miry pool. Then there were exciting times. The driver became volcanic, the whip hissed and snapped, and the oxen twisted and strained and occasionally voiced their feelings with a complaining low. The forward end of the log lay on a "lizard," a rude V-shaped sledge about six feet long, upturning at the point, and made out of the fork of some large tree. The woodland not yet invaded was full of giant timber, mostly clean-trunked gum trees, pluming out above into the foliage that formed the forest roof. Little was left standing when the choppers had passed on, save shattered or dead trees and ragged sapplings.

It was nearly sundown when I returned to the village around the mill. The only place to get anything to eat was at the mill boarding-house, and I was there in the washroom when the whistle blew for quitting work. The men came flocking in and scrubbed at the sink and 
combed their hair. Afterward they sat or stood around, chaffing, smoking cigarettes, and spitting at the stove. Pretty soon a man appeared on the porch with a hand bell, swung it vigorously a few times, and at that cheering signal every one started for the dining room. We had a good and hearty supper; but the workers in shirt sleeves and overalls did not linger over it. They were soon out engaged in a game of ball. The place was not very well suited to the sport; for there were buildings in the way, and there were stumps and bogs and pools, and there were wandering cows and horses which the ball sometimes encountered with a resounding thump, much to their consternation. The ball was erratic. It rolled under buildings, or it flew higher and put the windows in jeopardy, it went over fences, it embedded itself in the mud, and it dropped in the ponds and had to be poked after with poles. But these vicissitudes did not discourage the players, and they kept at the game till the full moon that hung in the east above the ragged woodland had changed from silver to ruddy gold, and the gloaming had deepened into darkness.

I went away that evening on the train; but a few hours later stopped off at a little town which was a trading centre in a prosperous farming country. A one-armed man was at the station to take charge of such travellers as wanted a lodging-place, and he piloted us up a rough hillslope toward the town's only 
I 6 Highways and Byways of the Mississippi Valley

hotel. Somewhere a calf was bleating, and we heard a whippoorwill singing. "That's the first whippoorwill that's turned up this spring," said the one-armed man. "I reckon winter's broke."

Our guide took us to a two-story wooden hostelry, "Delmonico's" by name, "Strictly Firstclass." In the dingy office, with its dim kerosene lamp and rusty stove, were about as many men as the apartment would hold, some playing cards at a small table, some merely talking, and all smoking. The landlord was in a brown study, trying to figure out where he would put his guests. They were so numerous that they could not have a bed apiece, and some objected to sleeping double. It was late, and I was ready to agree to almost anything. So he sent me with another man into a dirty little corner room, where we occupied a bed that creaked dismally at the least provocation, and the night was far from satisfactory.

In the morning, after breakfast, I looked around the premises in an effort to discover why the hotel was called "Delmonico's - Strictly Firstclass." The yard was a gritty slope of stone and gravel, with a speckling of grass growing on it, and bestrewn with sticks, tin cans, old shoes, and similar litter. Beyond its narrow confines the hillside was piled with telegraph poles and shaggy cedar fence posts. At the rear was a barren fenced-in space that served as a poultry ranch, cow yard, and pig-pen, and a depository for wood piles and 
for rubbish in great variety. All the neighboring backyards were put to much the same uses.

Near the hotel were ten or twelve stores, mostly in narrow one-story brick blocks, and the place also had its bank, its newspaper, and its photograph gallery, the proprietor of which described his art as that of "catching shadows." Business was dull in town and would be until fall. From March to October the farmers have little cash, and during this period they very generally "go on tick" at the stores, and do not buy at all freely. In carrying these accounts the stores either put on an extra price or charge ten per cent interest. When the crops begin to be marketed the farmers settle old scores and make more liberal purchases, but by spring most of the produce has been turned into cash, and the cash spent. If the crops fail there are dubious times all around. The farmers cannot pay what they owe nor buy more, and the merchants cannot collect or sell, and every one has to pinch and economize till nature is once more bountiful.

The country roundabout the town flowed away in pleasant hills and hollows for I know not how far. The fields were ample and rich and well-cultivated, and the winding streams delightful. My longest walk was an all-day ramble off westward. The air was very still and mild, and the soft blue sky was unsullied by a single cloud. I could hear voices, the low of cattle, and the crowing of cocks for a long distance; and with 
I 8 Highways and Byways of the Mississippi Valley

these domestic sounds was mingled the whistle of the quails, the cooing of turtle-doves, the cluck of blackbirds, the tapping of the "whickers" or yellowhammers, and the clatter and songs of many other birds.

The highway for some distance followed the valley of a creek - an innocent-looking stream with quiet pools and rippling rapids; but which evidently had its spells of savagery, for the ground on either side was much torn and furrowed by floods. All the space it rampaged over was abandoned to it and to the road, and this space was often very wide. The stream wandered wilfully to right and left with many a turn, and the road was continually crossing it. Nowhere was there any bridge, and in high water it must have been impassable, even for teanis. Beside some of the fords was an irregular line of stepping-stones, but many of these stones were precariously unstable and overflown by the water. Most crossings, however, had no aids other than a few sticks or a dead branch some foot traveller had thrown in.

Along the creek grew great sycamores, "ellums," and gum trees, misty-green with tender, new-starting foliage. The half-wild highway was common pasturage for cows and pigs, and a pleasure-ground for boys and fishermen. The boys fished, too; but that was only a small part of their fun. The streamside was to them enchanted land, a place for dreaming, for new discoveries, for flowers and birds and other things of youthful interest. I talked 


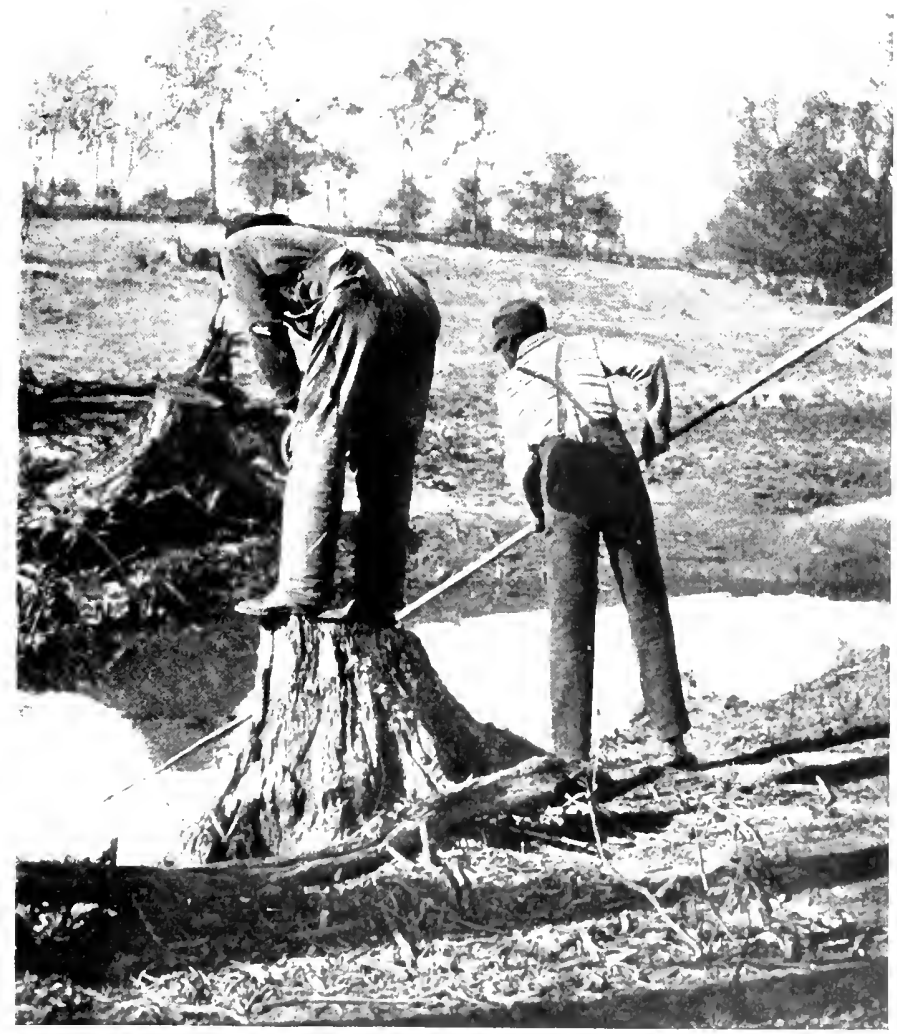

The FisherimeN 

with some of the boys - honest-eyed little fellows in ragged and patched overalls. They showed me the swimming-hole, and farther up the creek pointed out a pool where lurked a veteran pike, too wise to be caught, that was a foot and a half long; and they told me about the suckers and eels and trout, and about "the little topwaters, which stay near the surface and take your bait."

One pause that I made during the morning was at a cemetery on a prominent slope by the roadside. It was a large, ragged plot abounding in stumps, and growing up to thin grass, weeds, and bushes. Here and there were straggling flowers. Some graves were unmarked, and others had only rough fragments of native stone. Often the family lots were fenced in, but most of the fences were broken and half-fallen. Narrow boards were the common fence material; but there were several lots enclosed with pickets so that they resembled miniature hen yards. Frequently the single graves were fenced. Some had fence rails laid up around them, one was enclosed by great posts set snug to each other like palisades, and two or three were roofed over with rude little shanties. This unkempt, neglected ground of the dead looked strangely out of place among the clean fields about.

Noon came and I stopped for dinner at a log-cabin off on a byway. An old man and woman and their daughter constituted the family. The man had been 
I 20 Highways and Byways of the Mississippi Valley

furrowing out a field for corn with a little bull-tongue plough, and his daughter had been dropping the seed. He complained that the lower half of the field was as yet too wet for planting, and he reckoned he would have to shoot the corn into the mud with a gun. He was also disturbed because the field was inclined to be weedy, and later would abound in "cuckle burs."

The house was quite primitive, and consisted of one room, a shed, a porch, and "a mud and stick chimney." I could see light through numerous cracks in the walls as I sat at the table. There were two beds in the room, and a meagre supply of other furniture. Chairs were not at all plentiful, and the man ate dinner sitting in a creaking rocker, and the girl sat on a three-legged stool. We had pokeweed and sour-dock greens with fat pork, corn-bread, oats boiled with sugar, and lastly a vinegar pie. Some of these things were not at all bad, but my palate rebelled at the pie. For drink we had both coffee and buttermilk. The latter was in a jar on the table, and the members of the family dipped and drank several cupfuls.

The woman did her cooking over a rickety stove that troubled her by smoking when the wind was in the east. During the winter, the fire in the fireplace was kept constantly going, and she cooked over that. "If you have a good skillet," she added, "meat is better fried in the fireplace; and fireplace corn-bread is better, too." "If people e't corn-bread right smartly the way they 
did years ago, they wouldn't need so many pills," affirmed the man.

"Me 'n' my daughter like biscuit," averred the woman; "but flour's so high I don't make 'em only once a day."

After dinner we adjourned to the porch, and the man took a chew and the woman lit her pipe. She said a good many women used snuff; but she didn't believe in it and told about a neighbor who recently died. "She was a great hand for snuff," said my hostess, "and I'm satisfied it caused her death. She jus' sucked it down her windpipe and it clogged her lungs."

I said something about the inconvenience of getting mail off on that byway, but they responded they never had any mail. Still, they would have preferred being on the big road, especially in the months of frost and snow. "We have a tolerable rough winter hyar," said the woman.

"What work is there to do then ?" I inquired.

"We split oak rails for our fences and garden palings," the man answered, "cut cordwood, and cle'r land."

They were early settlers, and the man told how his folks came from Illinois about 1850 . “I was goin' on fifteen," he said, "and pretty well grown. We had a pair of steers hitched to a covered wagon. It was a long journey, and sometimes we'd git the chills an' have to lay up a while." 
122 Highways and Byways of the Mississippi Valley

"We hadn't no doctor's medicine then," said the woman; "but we'd git things out of the woods - black root, bur-vine root, wild cherry, dogwood - I can't name over all the weeds an' things my pap use to git. Mother'd dry 'em an' fix 'em up to take when we needed 'em."

"Yes," said the man, "we use to do a heap of our own doctorin' thataway. To break up the chills we'd go to bed and drink something hot and cover up head and years to throw us into a sweat. Boneset tea was good, and so was $\operatorname{dog}$ fennel, and walnut bark. The walnut bark we'd boil down till it was pitchy and make pills, or we'd take the bark and slap her on the front of the wrist where the nerve is to draw a blister. We'd try lots o' things like that for the chills.

"This was a wild country when we got hyar. There was only half a dozen families in all the region, and there was bears and pant'ers a-plenty. They'd steal a right smart of sheep and hogs; but when people got settled pretty thick around they drove the critters out or killed 'em. The last pant'er I knowed of was seen seven years ago. It run a nigger four miles down the river road, and then he clumb a tree near a chu'ch house whar they was havin' a meetin'. The people heard him hollerin' thar for his life, and they come hurryin' out to see what the matter was, and the pant'er scooted off into the woods. Thar ain't no savage animals left, but we have a good many wild turkeys and coons, 


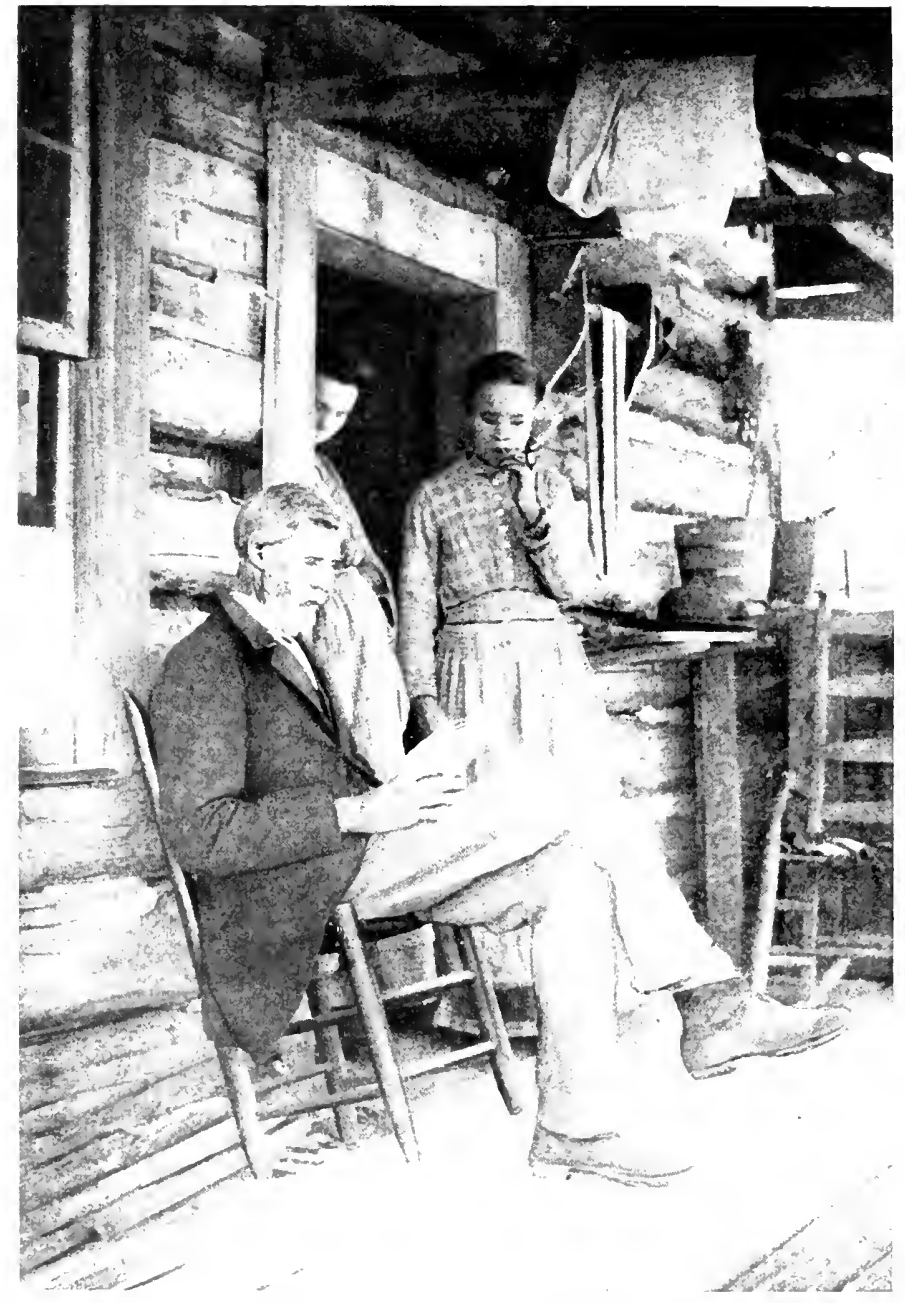

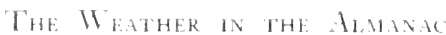


'possums and rabbits, and thar's some deer run around in the hills."

"Well," remarked the woman, "even if the dangerous critters are gone, this was a better country to live in then than now. The seasons has changed and ever'thing else. We had a heap better rains then and none of these dry years when you can't raise hardly anything. We use to set fires late in the fall and let 'em run through the woods to make feed for the cattle; but that ain't allowed no more, and the leaves and bushes smother out the grass."

"The cattle'd go to the range then in February," continued the man, "and in a little while they'd be plumb slick. We didn't have to feed 'em more'n three months, but now we have to feed 'em mighty nigh six."

They were old-fashioned people, pioneers by nature, and they could not adapt themselves to any but the ways of their youth; yet no doubt the changes have nearly all been for the better, and this part of Arkansaw seemed to me to have genuine pastoral charm.

Note. - Travellers who wish a closer contact with rural Arkansas than they get from the car window would do well to stop at a hotel in some large town and make short trips out into the country as the spirit moves. Some may, however, prefer to go at once to the lesser places and take their chances, as I did. The latter method is more entertaining, but it has its drawbacks and would not suit every one. The country as whole is too featureless to attract sightseers, and yet the life has a character of its own and repays acquaintance. 


\section{VII}

\section{LIFE IN THE OZARKS}

HE only portion of the Mississippi valley that lifts itself to heights sufficientily lofty to becalled mountains is in western Missouri. Here are the Ozarks. The name has a savage resonance very suggestive of the rugged wilderness, and I selected Cedar Gap, on the topmost crest, for my destination with eager anticipations. But I did not find the romantic region of my fancy. There were no mountains, and not even cedars or a gap. The gap had been filled across for the railroad, and the cedars which formerly "growed in the gap" had been cut. As to the mountains, they had evidently received their title by grace of contrast with the interminable levels that environ them. They are merely a vast upheaval of rounded hills, and nowhere do they lift into imposing peaks or ridges. However, I found the country had an interesting individuality of its own, and the pure bracing air, and the puffs of apple bloom in the abounding orchards, made beautiful the hillslopes and went far to compensate for the lack of wildness.

Cedar Gap Village, where I made my home for the 
time being, was very small and very rustic. Storekeeping was the chief industry. There were no less than six tiny emporiums, while the hamlet did not contain above a score of dwellings. The one street was littered with tin cans and papers, and on its margin were occasional woodpiles, farm wagons, and similar encumbrances. A scattering of teams and saddled horses was usually hitched to the wayside posts. One conspicuous feature of the village was a barn close to the highway that was pasted over with gay posters announcing that a travelling show was coming. The show was to be in a tent, " admission twenty cents, children under ten years half price, reserved seats ten cents extra." There was nothing mild and insipid about it; for the posters said, "You'll laugh, you'll yell, you'll scream with delight - a hurricane of fun, a whirlwind of amusement, a blizzard of mirth - doors open at 7 trouble at 8 o'clock sharp."

The hotel was simply a two-story dwelling. The front of its piazza was even with the street walk and had a low picket fence around the edge to keep the children from tumbling off, and to prevent stray cows or pigs from walking up on it. There was a gate in this fence opposite the front door, fastened with a halter snap; and the inconvenience of the fastening was such that the male habitants of the hotel generally stepped over the gate rather than trouble to open it. Most of the outlying farms were off on brushy 
I 26 Highways and Byways of the Mississippi Valley

byways, and the farm homes in themselves and their surroundings were marked by a good deal of careless neglect. You would naturally conclude the owners were unthrifty and made no more than a bare living; but this I was told was not so. Many of them had money laid away. They were not ambitious to have a fine house or make a show and outdo the neighbors. They had been used to frugal living and with it were content.

Often the homes were linked to each other and the village by obscure paths through the woods and fields, and I liked to follow these paths across the "breaks," as the steep forest hollows are called. It was ideal spring weather. The sky was clear, there was a gentle, beneficent warmth, and all the world of vegetation was putting off the winter lethargy, bursting buds and unfurling leaves and blossoms. Butterflies flitted about, insects buzzed and frolicked, and lively little lizards at my approach scurried with a sudden rustle through the dry leaves to the shelter of stump or fence. Mayapples, violets, and anemones were in flower, brightening the undergrowth; and occasionally I came across thorny clusters of wild crab trees crowded with blushing bloom. Cattle were feeding in the woodland, and I often encountered a little group of them and always was within hearing of the irregular tink-a-link of the cow-bells.

The chief highway of the region passed a mile or two 
east of the village. It was a main travelled road from Arkansaw to the northwest, and one day I was surprised and delighted to meet on it a caravan of white-topped wagons - veritable prairie schooners, with two entire families and the dogs and poultry emigrating to new homes. How like a vision of the past! The caravan had paused at the top of a rise to rest the horses, and when I drew near the patriarch of the tribe said, "Howdy," to me. "This hyar is a rough road," he added - "jolt and thump all the time; but I reckon the kind o' shake we been gittin' hyar is better for your liver than the kind we been havin' in the bottoms whar we come from. The children had got the color of a Yankee punkin with the malaria, and I thought it was time to leave."

At a farmhouse where I stopped later, I mentioned meeting these people, and the woman of the house said: "They were travellers. That's what we call 'em, and that's what they call themselves. Sometimes several wagons pass in a day; but they ain't so numerous as they used to be. Two years ago last fall we counted twenty-eight o' those covered wagons that went by hyar in one day. I've seen six or seven of 'em all in a string. Sometimes the people have cows a-leadin', and a calf in the wagon. They go all times of the year, but ginerally when a man wants to move thatavay he pulls out in the fall when he can find plenty of corn along the road and live off the country. A good many of 
I 28 Highways and Byways of the Mississippi Valley

the travellers are like the bums on the railroad. They understand the ropes and how to strike the ole settlers for what things they need without spendin' nothin'. They camp at night in the timber and help themselves to rails off your fences to burn; and it ain't much trouble to git their horse feed free. All they got to do is to slip over into a field and fill a bag with corn. Then the children run hyar and yender, to beg a little milk and a little bread and such like. People don't often take pay. It don't look generous, and if pay is offered they say, 'Oh, never mind the money. It's only a little we've given you. 'Tain't worth talkin' about.'

"Thar was a woman traveller told my ole man the other day that she and her family had been nine years in a wagon and never had stopped to settle yet; and I allow that most of 'em are folks that ain't quite satisfied nowhar. The good place is always just ahead, you know. Yes, they're shifty people - kind of an idle, gypsy set, though they're clever enough and good talkers. Some of 'em are well off and are on the lookout for bargains. They will buy a farm or a piece of town property if it can be got cheap, and then when they have a favorable chance sell it. But they are apt to be short up for money. Some of 'em travel in the middle of winter and the snow knee deep. They'll have a stove in the wagon with a fire in it and the stovepipe stuck out through the canvas.

"I wa'n't raised in this country. We used to live in 
the upper part of the state, and while we was thar they had a bad year in Kansas - no rain and everything e't up by grasshoppers. That set the travellers all goin' east, and every man, when we ask him, say he was goin' to his wife's folks in Ioway. It got to be terribly amusin' after a while, and we made a regular ole rhymed song about it. We had a dry season whar we was, too. There wa'n't any rain from the 1 $3^{\text {th }}$ of June till sometime in October. We owned about a dozen head of cattle and seven horses, and we had to draw water for 'em five miles. Our corn wouldn't ripen the ears, and we cut it and put it in shocks for fodder."

As I rose to leave, the woman went to the door and shading her eyes from the sunlight looked for some moments at a man passing along the road on horseback. "That's Grandpap Carver, I'm confidenced," she remarked. "Last I knew he was sick. This is trading day, and he's got a basket on his arm and is carryin' his eggs and butter up to the village. Saturday, some one from every family has to go to the village to carry the small truck we have to sell and buy what is needed. I usually send the children. They walk; but if I go I have a team. Things ain't bringin' as much as they did one while. Eggs have been as high as twenty-five cents a dozen, and butter twenty cents a pound. Now we only get fifteen cents for butter, or ten cents if we sell to a neighbor. Eggs are sixteen 
I30 Highways and Byways of the Mississippi Valley

cents, and 'tain't likely we'll be gittin' that much longer. I've known 'em to go down to four cents."

That it was a trading day was quite apparent when I returned to the village. The place was not exactly lively, but an unusual number of people were hanging about the stores and the sidewalks, and this continued to be the case till late in the evening. However, after sundown, there was less trading than visiting going on in the stores, and if you looked in you were likely to see by the light of the dim kerosene lamps little groups of slouchy men, with rough clothing and misshapen hats, talking and smoking as they sat or lounged on counters, chairs, and boxes.

It was customary in the neighborhood to have frequent "singings." The young people assemble at one home or another for the purpose nearly every Saturday night. This time the musically inclined gathered at a small dwelling next door to the hotel. The house was packed, and for two hours I heard the participants singing Gospel Hymns with loud, uncultured, unabashed voices.

I listened to more of the same kind of singing the next day at a church I attended in a good-sized town a few miles distant. A chorus of about twenty gathered around a cabinet organ, and how they did sing! There was no lack of energy. They stood up and opened their mouths and shouted. Modulation and delicacy were beyond their ken. They enjoyed singing, and the 


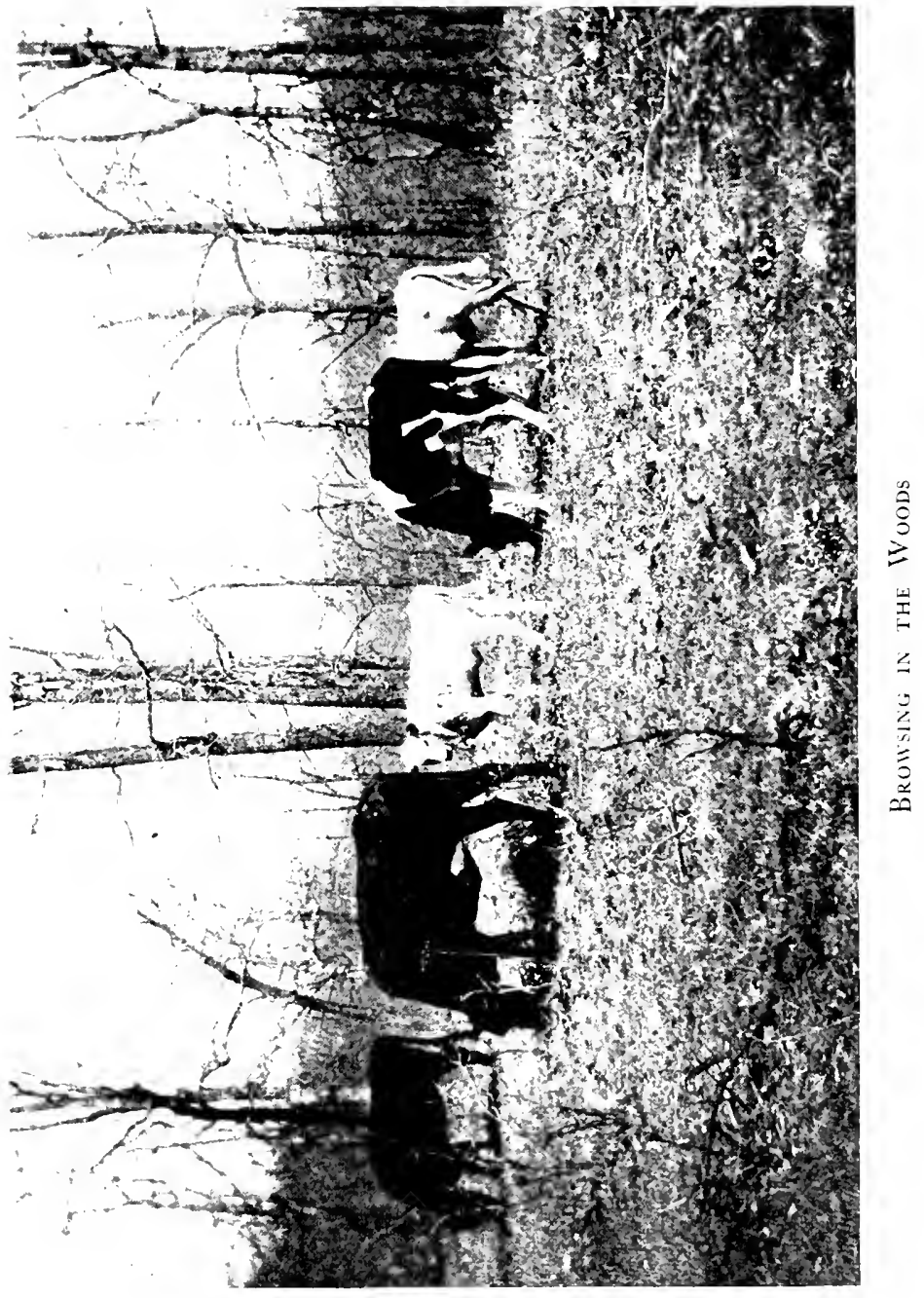



people in the pews enjoyed hearing them and had not a suspicion of the crudity. Their earnestness and vigor were attractive; but those hard metallic tones gave one's sensibilities a jarring, and I wanted to stop my ears and run.

The preacher, too, was a man of noise rather than of refined perceptions; and he had something also of the dramatic and sentimental about him. Often he became decidedly frenzied and would thrash around with his arms in red-faced, sweating fervor and have to mop his features with his handkerchief. One of his assertions was that all the great business men of the country were persistent church-goers. "There is Mr. Rockefeller," said he, "who is worth billions. Nothing would keep him from going to church short of putting him in the penitentiary."

"And that's just where he ought to be," whispered a belligerent-looking man in front of me, to himself.

The minister preached what the Ozarks folks call "a graveyard sermon." He worked on the feelings of his auditors cruelly, and made some of the women cry. Among other things he told with great detail the story of Abraham's preparations to sacrifice Isaac, and lingered especially over the father with knife in hand ready to "cut his son's throat." It was barbaric and horrible. Of course he made some good points; but as a whole the service was pretty harassing, and I was glad when it ended and I could escape into the mild 
${ }^{32}$ Highways and Byways of the Mississippi Valley

outer sunshine. Even then I was not in "the Elysian fields," to quote a phrase of the preacher's; for a skunk had visited the neighborhood and perfumed it most thoroughly, and the worshippers hastened along the board walks making comments that had nothing to do with the sermon.

There were five churches in the town, but some were only open once a month, and none oftener than every other Sunday. They were all weaklings, and to an outsider it seemed as if they were exalting denominationalism above Christianity.

I have spoken of the place as "good-sized," but that was only by comparison with other communities in the region. The streets, though wide and regular, were nearly overgrown with grass, except in the very centre of the village where the stores were. The stores fronted toward a large, open square which was a desert of stumps; but young trees had been started, and it would perhaps sometime be an oasis of shadowed lawn. The pigs rambled and investigated singly and in groups about the municipal thoroughfares and did the city scavenging. They were lean, lanky creatures of the variety known as razorbacks, and some of them, as one man said, "had noses long and slender enough to drink out of a jug." The city dwellings were nearly all of the cottage type, and few attained to a second story. Many of them were set on blocks and had no cellars. Trees were plentiful, but none were large 
enough to have dignity and impressiveness. The place was still infantile, and many years would have to pass before it acquired repose and charm.

I walked out into the country and found lodging for a few days at a log house in a glen among the hills. The soil in this vicinity was thin and full of flinty rocks, and the woodland on the slopes was ragged and unthrifty; but in the bottoms the stones are laboriously picked off the meadows and you find pleasant tracts of green. Near where I lodged several fine springs welled forth unceasingly their crystal fountains, and the water formed pretty little "branches" that wandered away through the grasslands and cultivated fields. Here and there amid the shrubbery that bordered the rivulets I saw the white blossoms of the wild plums and haws, and still more noticeable were the frequent red-bud bushes, every twig loaded with pink bloom. At a certain turn of the road, a half mile from my dwellingplace, was a level bit of grass convenient to a stream where the "travellers," with their canvas-topped wagons, often camped for the night. The charred coals and remnants of their fires, the husks of corn left over from feeding the horses, and some empty tin cans, showed plainly their recent presence.

Log houses were plentiful, and some of them were new. To erect one was no great task or expense. A man could get the logs ready himself, and then he would invite the neighbors to the house-raising. The usual 
I34 Highways and Byways of the Mississippi Valley

dimensions are fourteen by sixteen feet. "A pretty good working crowd will hoist the logs into place and get roof and all done in a day; but if too many gassers are there, and they put in a lot of time tellin' stories, it may take another day."

I noticed that one local cabin had no windows. Its eight inmates were a family of ne'er-do-wells, who, rather than exert themselves to cut a window opening, preferred to light a lamp when cold or storms obliged them to keep the door shut. The children went barefoot all winter, and they were said to live largely on bread and molasses and wild onions; and yet they seemed healthy, and the smallest girl was declared to be, "jis' as fat as you ever saw a little pig in your life."

Another building that interested me was a white schoolhouse on a hilltop. It was set well back in a stony yard, with thin oakwoods roundabout ruddy with the first hints of new leafage. There was no fence, and often as many hogs, sheep, and cows were around the building as children. The outer appearance of the schoolhouse was not bad except that the door was cracked and rickety, and nearly one-fourth of the window lights were broken. It was set on blocks, and sometimes the wandering hogs slept under it at night, or reposed there in the heat of the day while the school was in session. The worst of this was that they left their fleas behind, and there were times when 


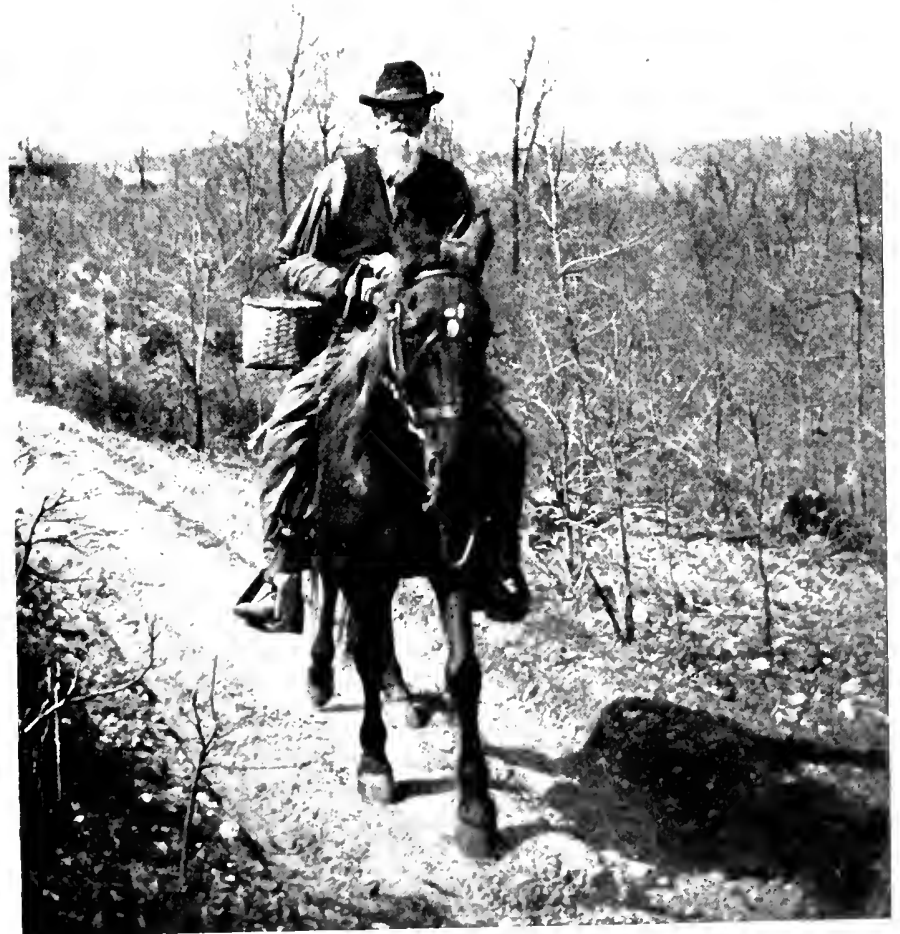

Golno; 10 Makket 
the teacher and scholars had distressing experiences with the vermin.

The interior was decidedly dingy, with unpainted, sheathed walls, and the floor dirty and littered. There were two rows of long desks with seats attached to the front, and each seat could be made to hold five or six pupils by squeezing, and would give comfortable accommodation for four. The desks were made of splintery hemlock boards, and were much marked with chalk, pencils, and ink by idling occupants. One or two were gone entirely to smash and the fragments lay in a rear corner. A big rusty stove, with the name "Solid Comfort" in raised letters on either side, stood in the middle of the room, and a wobbly stovepipe connected it with the chimney. The stove had seen hard times. One leg was broken and had been pieced out with half a brick, and a stout wire encircled the entire stove just under the rim to keep the sides from caving out.

For the teacher there was a rude little table, hammered together by some farmer. No chair accompanied it, though one had originally been supplied by the school authorities; but it had gradually become very decrepit. In its last days it had lost its back, and to supply this deficiency the teacher when she used it would place it against the wall. After it finally went to entire ruin, the teacher "either fetched one herself or did without."

It was not thought worth while to put a lock on the 


\section{I36 Highways and Byways of the Mississippi Valley}

door, because it would be soon broken; for the boys liked to go in there evenings and Sundays "to tear around." Often tramps took possession for the night, built a fire in the stove, and made themselves at home. School began some time in August and kept continuously for twenty-four weeks. The first half of the period attendance was good; but the long term became wearisome and many dropped out later. The school might start with thirty or forty pupils and end with ten.

One evening we had a long talk about schools at my boarding-place. I had sat down in the best room. The sagging uneven floor was half covered by a rag carpet, and the walls were pasted over with newspapers. In one corner was a bed and at its foot was a cot bed. In all the houses of the region beds were a conspicuous article of furniture. Few rooms were without at least one, usually from necessity, but in part from force of habit. People of means put a bed in the parlor just as their neighbors did, even when the house was large and it could easily have been spared.

The weather was chilly, and Mr. Doten, the man of the house, brought in some coals on a shovel from the kitchen stove and put them in the fireplace. Then he knelt down on the rough hearth, laid on some kindlings, and encouraged a blaze by wafting his cap. The fire soon flamed up brightly and began to eat away at the backlog, and the whole room was lit up with its fitful glow. "I tell you this fire keeps me busy in the 
winter," said the man. "We use a two-horse load of wood a week. But that wood warms a fellow twiceonce outdoors cutting it up and again in here burning."

$\mathrm{He}$ had seated himself in a rocking-chair to enjoy the heat and smoke his pipe. The man's grandson, a little boy in overalls and cowhide boots, had lounged down on the convenient cot bed and was watching the flames. The man wore boots, too. This was partly because the soil of the country was full of flints, that were very destructive to light footwear, and partly on account of ticks. "You're bound to get acquainted with them ticks in summer," explained the man; "and there's a little kind of a bug we call jiggers that's worse still."

Presently Mrs. Doten and her daughter came in. The family had moved from Iowa a few years before, because, as Mrs. Doten said, "It didn't agree with our health there. When you woke up in the morning you were tired and had a bitter taste in your mouth. Besides, wood was scarce. That's what broke me of roastin' my own coffee. I only made a fire when I had to."

The daughter was a school-teacher. "We tried to get Jenny the school here," said Mrs. Doten, "when we first come; but they didn't think she was strong enough, and they jis' got somebody no account to beat and thump, and who didn't learn the scholars a thing. You see each district has three directors to manage the schools, and some of 'em don't know beans. 'There's 


\section{I38 Highways and Byways of the Mississippi Valley}

school directors that can't read or write; and often they'll never visit the school the whole year through."

"Where I was last year," said Jenny, "I had to wait quite a while for my pay because the president of the directors was in jail for gambling."

"How much are teachers paid?" I asked.

"From twenty-five to forty dollars a month," was Jenny's reply; " and out of that comes our expense for board, sometimes only five dollars a month, sometimes as much as seven and a half. One thing a teacher is expected to do is to go once during the year to each home that sends children and stay over night. You have to do it or the people feel slighted and think you are proud. You get into some pretty poor houses. I've been where the snow fell through holes in the roof on to the table while we were eating; and I've been where the whole family slept in one room.

"Every one judges your work at school by the order you keep, whether the children learn anything or not. I almost lost my reputation one year through a girl who wouldn't mind; and if I tried to use force she would scratch and fight. Finally the directors came in and turned her out, and then the rest of the children in that family left, too.

"The studies we make the most of are spelling and arithmetic. The people go wild about those. We always used to have a head and a foot to the spelling class, and whoever stood at the head when the day 


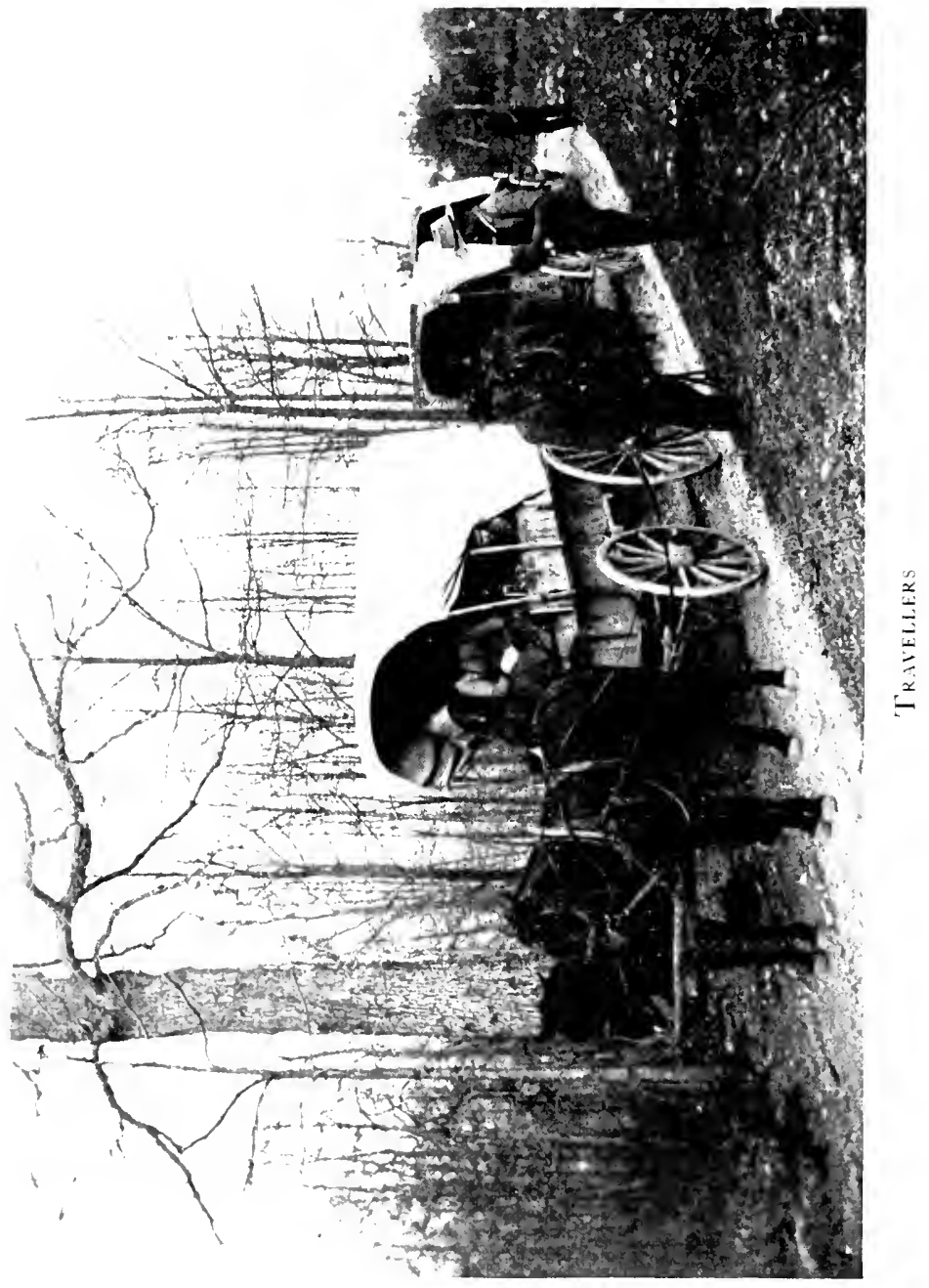


ended received a credit and began at the foot the next day. On the last day of the term the scholar who had the most headmarks was given a prize. But that custom is gradually going out. There's one girl in this district has studied her spelling book so much she spells page after page without having a word pronounced for her; yet she's not much in anything else. We often have spelling-downs in the school, and you need only ask, 'Who wants to choose up ? - Who wants to be captain ?' - to have half a dozen calling out, 'Me.' They like to cipher down, too. That's done on nearly the same plan as the spelling contests. Sides are chosen, and the last one in each company goes to the board, the teacher gives an example, and they figure as fast as they can. The one that gets done first beats and the other is out of the game. The next child from the side of the beaten one steps to the board and a second example is given. So the contest goes on until all on one side are beaten.

"Some time during the term we have a school entertainment. Perhaps it will be a box supper, and each lady will bring a box filled with a nice lunch. Her name is inside, and all the boxes are put together, and then each man buys a box for fifteen cents. When he looks inside he may trade boxes with some other man."

"That's not because he don't like the grub," interrupted Mr. Doten; “but he'd rather have some other 
I 40 Highways and Byways of the Mississippi Valley

lady. You see he has to take the one whose name is in his box and eat the lunch with her."

"I like the pie suppers best," said Mrs. Doten. "Each lady brings a pie with her name on the bottom, and the pies are sold for ten cents apiece. There's all kinds - apple, peach, blackberry, sorrel, pumpkin, sweet potato, and I don't know what."

"The proceeds are used for buying a dictionary or books for the school library," continued the teacher, "or a new blackboard or an organ. Besides the eating, there's a short programme. A stage has been built at one end of the schoolroom on as small a plan as possible, and the scholars get up there and have their recitations, singing, and dialogues. The room is sure to be crowded, all the seats full and some persons standing. A good many come early - even an hour beforehand - to make sure of a good place to sit."

"They have another great time last day of school," remarked Mr. Doten.

"Yes," said the teacher, "and the children come in the morning dressed in their best. Sometimes we have a big dinner at the schoolhouse. The patrons bring all sorts of good things to eat, and after dinner, perhaps the children spell down, and there's speeches. The pupils make the teacher a present of an inkstand, album, card tray, or something of the sort; and she has to supply a treat of candy for them. I usually get a pailful - twenty-eight pounds. Then I have to put 
it up in bags or boxes, a half pound for each scholar, and what is left is passed around among the visitors. If you didn't buy that candy the children'd feel terribly insulted, and think you were the stingiest old thing that ever was."

"We have the biggest crowd at our schoolhouse when there's a spelling-down between our scholars and those of some other district," said Mrs. Doten.

"I don't know about that," Mr. Doten commented. "I've seen it packed fullest when we was havin' protracted meetin's."

It seemed that these meetings were revivals of religion, and there had been three series the previous winter, each under a different minister, and each continued from evening to evening for about two weeks. "People come for miles," said Mr. Doten, "and the warmer the meetin's get the more they come. A good many are there jis' to see the fun, same as they'd go to a dog fight or a horse race. The minister does all he can to have an excitement, and when he sees people's feelin's are all worked up he begins to clap his hands and shout, 'Bless God! Bless God!' over and over again."

"You never saw anything like it," added the teacher. "The people will laugh and cry and scream and holler, and it's as good as a circus. They walk around and are hystericky as can be. I remember how one old man last winter wagged his head and snivelled and 


\section{42 Highways and Byways of the Mississippi Valley}

squealed and looked real idiotic. If he had been my father and cut up like that I'd have slunk off home."

"It's what I call a 'distracted' meetin'," said Mrs. Doten, "they make such a big fuss. You can't tell what they say; but they're havin' what they speak of as 'a good time.' After the service the minister calls for 'seekers' or 'mourners' to come up in front; and friends of the unconverted will go about in the audience and talk to those they think ought to respond to the minister's call; and if they have a strong will they'll get those to the mourners' bench that didn't want to be there at all. Then one o' the local men will get down to pray and say, 'We ax thee, Lord, to reveal thyself to these poor sinners,' and such things, and some of the seekers will stand up and make a profession and say a few words. The persons that get religion at such times are mostly women and girls, and perhaps a few young boys not over fifteen or sixteen years old, and they generally backslide and are ready for the next big meetin'."

"Well, the preachers make a good thing out of it," said Mr. Doten. "I know the Methodist minister that come here was paid eighteen dollars in money and given twenty-five dollars' worth of provisions. The provisions and part of the cash was begged for him around at the houses, and the rest of the money was got in the two Sunday collections."

"I didn't like him," was the teacher's comment. 



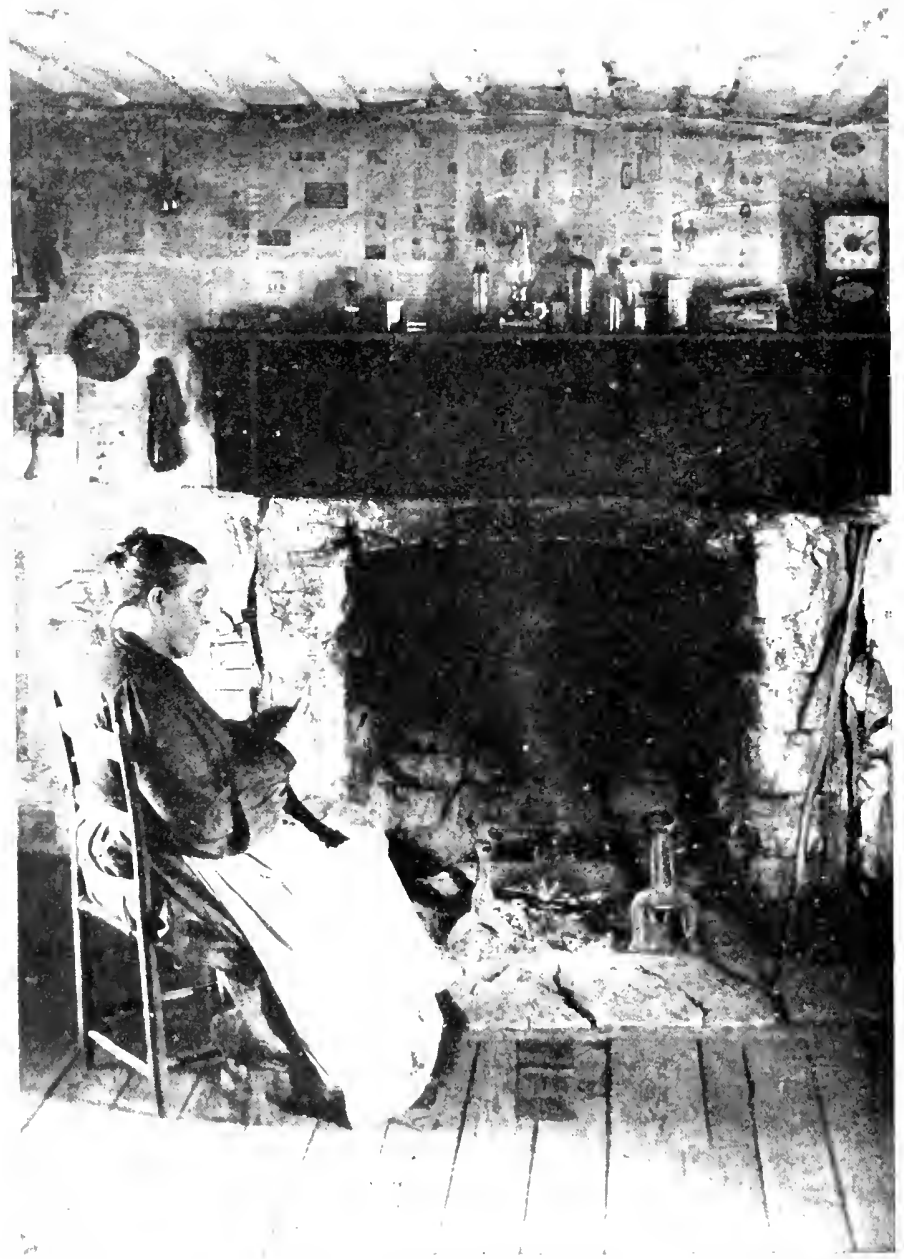

BESIDE IHE KITCHEX liter 
"That's because he claimed the girls would go to hell if they had beaus to and from service," responded Mr. Doten. "He said they thought so much about the fellers that was goin' to take 'em home they didn't listen to the sermon."

"These meetings pretty nearly ruin the schoolhouse," said the teacher. "We had a prayer-meeting where I taught last year, and the room was in such a condition the next morning I sent the smaller children home, and then I had the older ones get water and we scrubbed out. There was tobacco juice all over the floor and on the desks and stove and in the water pail."

"Yes," corroborated Mrs. Doten, "they spit till I wish I had an umbrella. I have to gather up my skirts, for there'll be great pools, and you need a boat to get out."

"In the town churches there's a fine for chewing and spitting on the floor," said Mr. Doten.

"I like to chew gum," remarked the boy, who was now sitting on a stool near the fire, knife in hand, making a corncob pipe for his "grandpaw"; "but our teacher won't let us chew it in school time. We chew at recess, and when we come in we stick it on the stoppers of our ink bottles. If we keep it in our mouths she makes us throw it in the stove."

"Some of the young men that chew gum put theirs, when not in use, behind one of their ears," observed the teacher. 
I44 Highways and Byways of the Mississippi Valley

"But for downright greenness," said Mrs. Doten, "you ought to see the young fellers and their sweethearts that come from back in the country at the Fourth of July picnic in the town. They walk swinging along hold of hands like little children. That's their idea of courting. Right around here the usual way for a young man to court is to call on his girl Sunday evening and sit by the fire with her after the old folks have gone to bed. They are great hands, too, for corresponding even when they live not more than three or four miles apart. Often they go for a buggy ride on Sunday afternoon. Some think it ain't quite proper for lovers to ride in the evening. The people here are always suspicious of what they're not used to, and suspicion is a bad sort of coin for anybody. One of our best neighbors is a woman that a good many call a foreignor. 'She don't talk like other folks,' they say; but she's jis' a broad Yankee from Boston. She's real good if there's sickness, and is frequently sent for. When she gets to the sickroom she takes charge at once and ain't at all backward about tellin' what ought to be done. I went with her once. A girl was sick, and soon as we were in the house she said, 'Goodness alive! we've got to clean up some of this dirt, or the girl will die. That's what's the matter with her.'

"So we begun cleanin', and at the same time she sent home most of the relatives. They all come if any one is seriously sick, the whole outfit of 'em, 
perhaps twenty or thirty, and sit around in the way.

“Two years ago the Massachusetts woman's mother who had been living with her died, and our people never see such a funeral. Talkin' afterward they said, 'Why, she never made a bit of fuss. I don't believe she cared a cent; and besides, she dressed up like she was goin' to a fine dinner.'

"They thought she showed disrespect. The habit here is to go to funerals in your work clothes. Often the men wear their overalls. It's the same at the country churches - the older men have on overalls and the brown duck coats they work in, and the married women all wear sunbonnets. The young men dress up some, but in warm weather they'll go to meetin' without coat or vest."

"Well," remarked Mr. Doten, "I've seen the preacher take off his coat in the middle of his sermon when he got warm."

"The minister has a good long sermon at the funerals," Mrs. Doten resumed, "often three-fourths of an hour, and I've heard 'em go on for twice that time. The near relatives think they got to show how sorrowful they feel, and there's lots of rippin' around, cryin', and screamin'; and they tell how bad they've been to the dead and how they wish they'd been better; and the preacher helps that sort o' thing along all he can. If there's anything especially distressing or touching about 
146 Highways and Byways of the Mississippi Valley

the person's sickness and death he's sure to bring that in; for it's supposed to be a credit to him - shows his power - the more screechin' there is. I used to have a good deal of sympathy for the near relatives of the deceased, they seemed to be so overcome at the funerals; but their screechin' is jis' the fashion, and now it don't affect me no more than to hear the piggy squealing out here.

"At one funeral last summer a man had lost his wife, and when time come for the service he felt so bad he didn't want to do anything but wander around outside, and 'twas all we could do to get him into the house. But he was married again in six months. He could have kept a loaf of bread over of his first wife's baking for his second wife's eating if he'd had a real good place to put it. They always remark and joke about a man that don't wait a year after his wife's death."

"I suppose," said the school-teacher, "that a man misses his wife here in the Ozarks more than anywhere else in the United States. She does the housekeeping and she does a good deal of field work, too. I know I've been spending half my time lately dropping corn and helping plant potatoes. The women do the milking, and they go out sprouting with axe and mattock in the fields and pastures, and they pick up loose stones off the grassland, and do all sorts of jobs. Then there's no conveniences around the houses. It's an old saying, if a woman marries a Missouri man she'll have to 


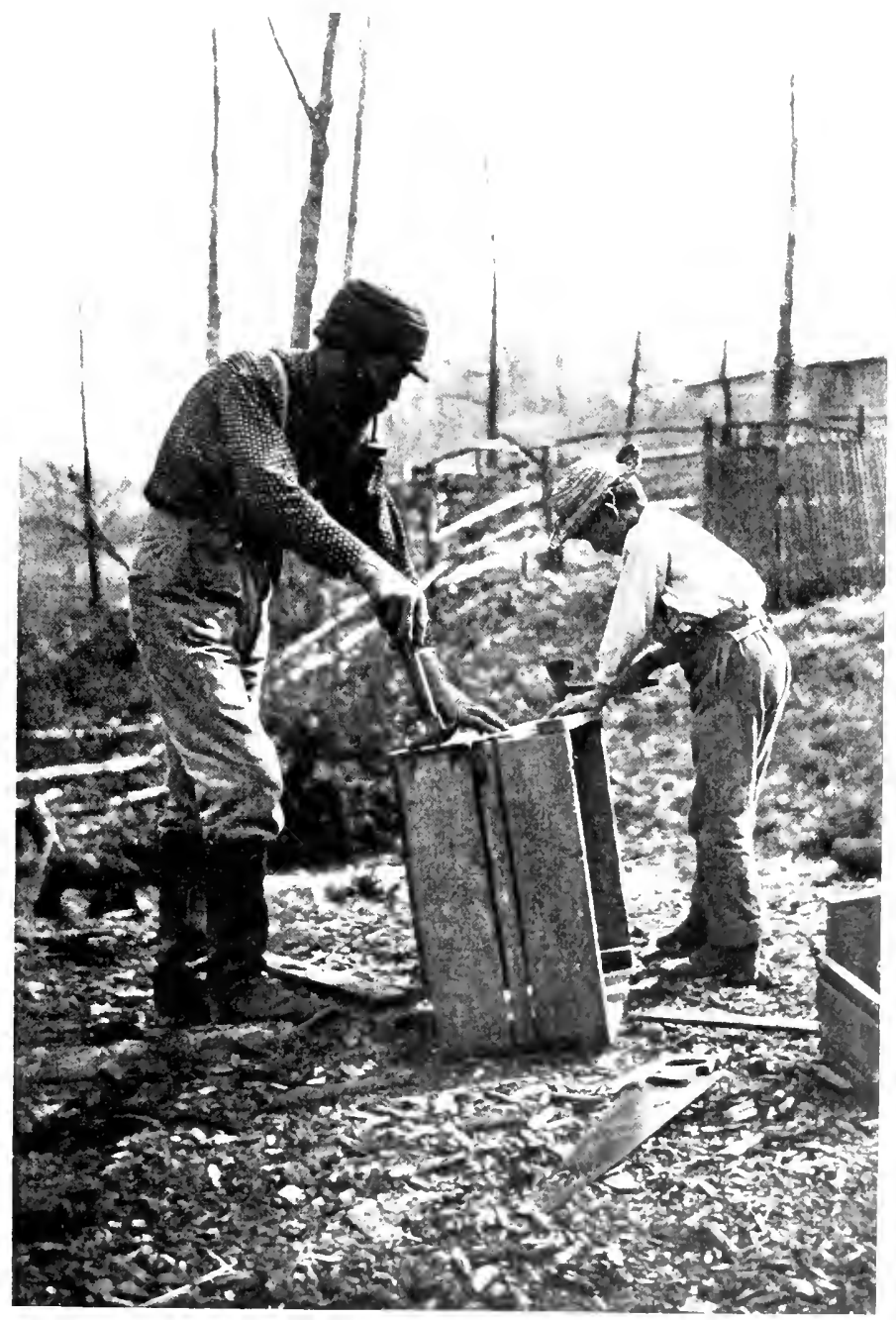

Makin: a Hen-conp 

carry water half a mile up hill all her life, and that's about so. Our spring isn't more than three rods from the house, but not many families are so lucky."

The little clock soberly ticking on the fireplace mantel showed that we were sitting up late for dwellers in that region, their habit being to retire early, and likewise to get up early. The boy had long ago left his knife and the cob pipe he was making and was asleep on the cot bed; and now I was shown to my apartment, and soon the house was quiet.

Note. - The Ozarks as mountains have no attractions worth mentioning, but as big, rolling, half-wild hills they are very handsome. Seymour is an excellent stopping-place and is near the crest of the ridges. The landscape environing the town is commonplace, but the tumbled waves of upland are within easy driving distance, and in what you see there, and in your contact with the inhabitants, you will find much that is decidedly enjoyable. 


\section{VIII}

AT THE MEETING OF THE WATERS

$\mathbf{W}^{\mathrm{H}}$

HERE the great river from the east joins the great river from the north stands Cairo, though not exactly in the apex of late years; for the Mississippi has moved away somewhat and left the town a little up-stream on the Ohio. The place is probably not charming at any season, and in the spring of the year, when I was there, it was partially flooded and appeared decidedly dismal. Dinginess and dirt were universal, saloons abounded, parading their doubtful friendliness under such names as "My Brother's Place" and "Uncle Joe's Glad Hand," and the railroads monopolized the water front, where their engines were constantly hissing and hooting and banging about, filling the air with gas, soot, and cinders day and night.

To offset all this the river itself with its traffic and its bankside workers and loiterers is unfailingly picturesque and interesting. There is no end of steamers and scows, rafts and tugs, houseboats and skiffs, draymen, roustabouts, and loafers. Here are life and variety and excitement, and the townsfolk of the humbler sort find genuine pleasure in lounging along 


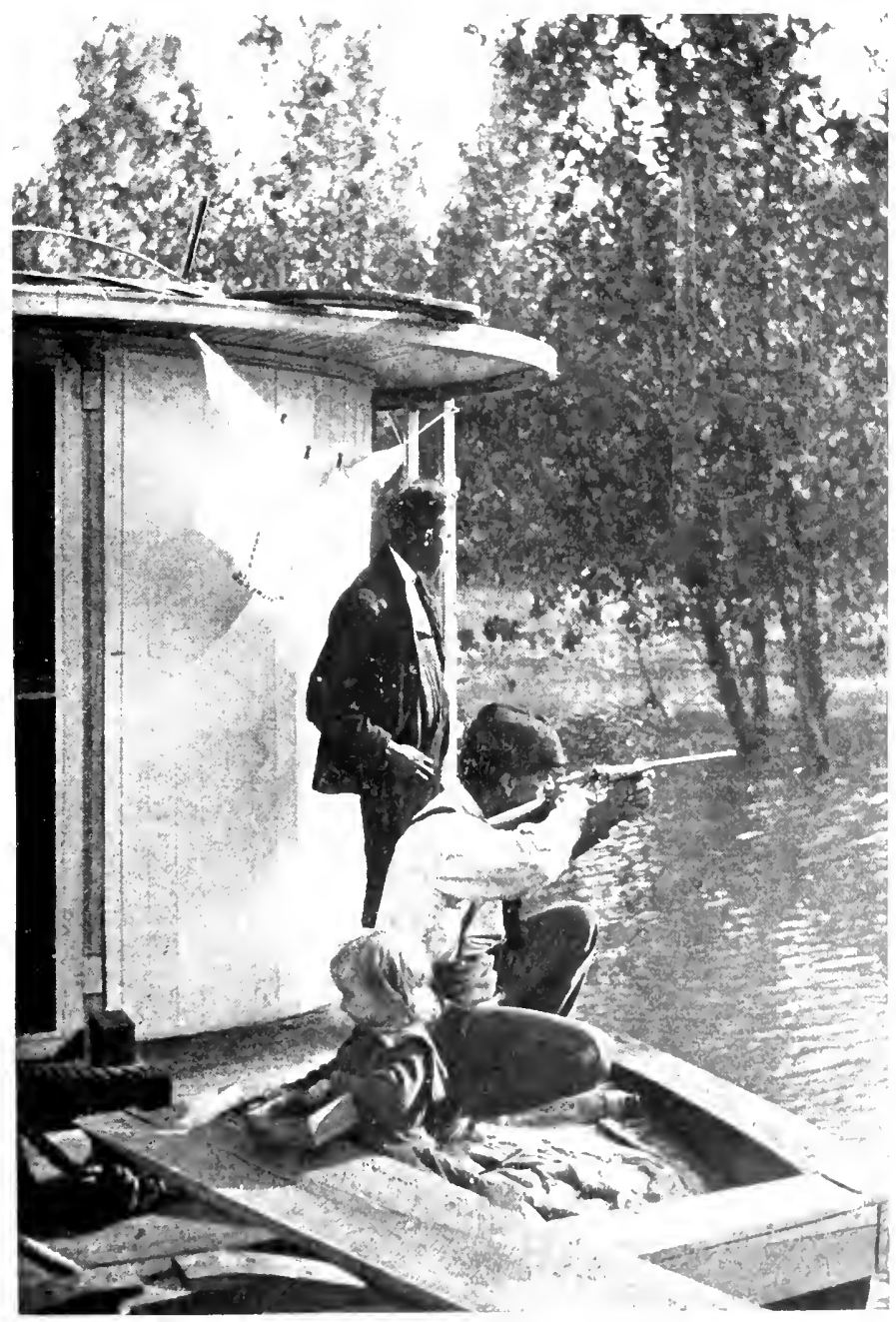

Prosplets OF A BIACKBIRL PHE 

shore to fish or to lose themselves in drowsy contemplation while they watch the changing scene. The waterside people are always ready to talk and to retail their opinions and reminiscences, and I had many an entertaining chat with them. One of my chance acquaintances was an old negro accompanied by a little boy, and both of them fishing.

"Some men up and down de river make a livin' fishin'," said he; "but I cain't. I have to work. I reckoned though I'd put in a little while hyar dis atternoon. Fish are jes' natchul good eatin' dis time er year. My wife does most er de fishin'. She goes idle times when she ain't washin' or ironin'. Yisterday she done got a fish on her line with a haid bigger'n dis boy's haid. De fish so big an' strong she say it was like pullin' on a log to git it up out er water, an' when she see it she was dat skeered she didn't dast to haul it to shore. She say she ain' gwine fool wid no such fish, an' she was mighty glad when it git off de hook.

"Dat make me think 'bout de time when I fust come to Illinois. I was bred and born and raised up right in Richmond. We had all kinds er fish dar. But I settled in a town eighteen or twenty miles back in de country hyar, an' one day de market man got some salt water fish sent him. I was on de street soon atter dey arrive, an' I see a big crowd a roun' de market, an' I run to fin' out what de matter. I reckoned somebody done got killed. But de people was jes' a-lookin' 
150 Highways and Byways of the Mississippi Valley

at one er dese hyar flounders. Dey ain' never heard tell er nothin' like dat befo' - a fish wid both his eyes on one side. De man I worked for was dar, and when he see I know de fish he say, 'Is he good to eat?' I tol' him dat he shore was, an' he bought him, an' he give my ole lady half a dollar to fry dat fish. When it was serve on de table, suh, seem like he crazy it taste so good. He didn't lose no time sendin' for mo', an' atter dat he had flounders as often as he could git 'em."

The fisherman paused while he pulled up his line and examined his bait. "De fish doan' seem to be bitin' to-day," he commented; "and yit ole man Dawson nabbed some big catfish right hyar early in de week. I'm sati'fied dey are mo' whar dose come from, an' dat what put me in de notion er fishin'."

Down at the lower end of the town near a great elevator that loomed up on the verge of the river, I made friends with some people on a houseboat. Their little vessel was hitched to the shore, and a plank served for passage from land to deck. The boat had two rooms, and was occupied by two families, including several children, the youngest a tot that could just walk, the oldest a boy of ten. The little folks all delighted in the river. It afforded them endless amusement. They threw in sticks and stones, sailed toy boats of their own manufacture, they fished and splashed and watched the coming and going of the river craft, and the older youngsters went out rowing 
in the skiffs. Their life looked adventurous, and it was a wonder they did not come to grief a dozen times a day. But I could learn of only one serious mishap. A week or two previous the boy of ten had fallen off the guards; "and I just screamed," his mother explained to me. "I couldn't think, and I didn't do a thing to help; but my husband was near by and he jumped in and pulled the boy out, and that boy never even caught a cold because of his ducking."

Among the rest of the inmates of this boat was a colored lad named Billy who did odd jobs for his board. I got him to row me down to the mouth of the river. He was delighted to go and chuckled as he rowed away, for he had gotten rid of washing the dishes. He was a boy with a history, though I imagine his relation of it was eked out with fiction. His left forefinger was missing, and he said he had a bullet in his shoulder that made his arm ache in dull weather. Both the suffering shoulder and the crippled hand were the result of a Fourth of July celebration. His finger was shot off with a toy cannon; but he got patched up and in an hour or so joined his comrades; "and I was soon monkeying around wid de boys," said he, "same as befo'. One of 'em had a little popgun. It wa'n't loaded, and we was havin' a jolly time pointing it at each other when all of a sudden it went off and hit me in de shoulder. I couldn't use my arm for a month; and yit de gals treated me so well all dat 


\section{52 Highways and Byways of the Mississippi Valley}

month my arm was in a sling I had de best time of my life.

"Later I went on to a United States training-ship at New Orleans; but dey abuse me on dat ship and I runned away. I was green enough to keep my uniform on and wear all my pistols and knives. So dey got a hold er me in Memphis an' took me back; but I run away again, an' dey'll never ketch me now."

Between Cairo and the Mississippi is a half mile of lowland overgrown with willows and cottonwoods. The water was up and this low ground was flooded, yet not so deep but that one could see the tops of the withered last year's grasses and tall weeds. On these bottoms bordering the Ohio lived several amphibious families, evidently prepared for all emergencies. Ordinarily they were land dwellers; but the foundation on which they erected their tents and shanties was a raft or scow; and though this rested on the ground most of the year, it was set afloat when the water encroached. One man, however, had sought a different means of escaping the flood. He had perched his hut well up among the branches of two great cottonwoods. It was safely above the reach of the freshets, and a dog was on the porch standing guard in his master's absence. Near by were the rest of the home belongings heaped on rafts and platforms. The largest raft served also as a refuge for the hens, which were picking about or roosting apparently quite content. "They better be careful 
and not tumble in," said my oarsman. "If a chicken's feathers git wet he's gone. He cain't set up on de water like a goose."

Not far away was a neighbor's raft on which was a home and two cows and a calf. The creatures had little room to move about, yet there they would stay till the water receded.

As we rowed leisurely along several steamers went down or up the river, most of them railroad ferry-boats loaded with freight cars going to or coming from a station on the west bank of the Mississippi. In their wake the great waves rolled away and set our little craft to pitching and rocking in a manner that was very exhilarating.

Presently we came to "the coal fleet," and had to make quite a detour to get around it. This fleet was an immense mass of loaded coal barges moored close together and attached to trees on the shore by great ropes. The coal was destined for towns up the Mississippi; but the steamers which towed the boats down the Ohio from the mining regions were unable to struggle up-stream with all they brought down, and a part of the tow had to be left here to be sent on later.

While we were passing the coal fleet my companion let our boat drift, and he watched attentively the blackbirds fluttering about the floodtrash that had lodged against the barges. "They are pickin' up worms, toad frogs, and one thing another," he said. He 
I 54 Highways and Byways of the Mississippi Valley wished he had brought his rifle; for he was confident he could easily have shot enough for "a pot pie."

We went on until we were at the meeting of the rivers and saw the waters leaping and eddying in rough contention. Each river was distinct from the other in color as far as the eye could see down the broad channel. The Ohio was a light yellow and the Missouri a dark coffee color. Both were laden with sediment, but the latter carried by far the most.

On our way back we were overtaken by a shower. The sun glimmered through it, and my rower remarked, "Shine and rain together - the devil's beatin' his wife."

"Why is he beating her?" I asked.

"Because she done burnt de biscuits las' Sunday," was the reply.

I wanted to see some of the farming country in the vicinity, and one day I made a trip across the Mississippi. The region on the west shore had all been under water, even the land behind the levee. The roads were not passable to a person on foot, and I kept to the embankment and followed its curves and angles for four or five miles. Sometimes I had the river in sight, but usually the levee was well back inland, with half-flooded cornfields and heavy growths of cottonwood between it and the stream. Occasionally I would see the tips of tall steamer smokestacks with their black smoke plumes moving along beyond the trees and never get the least glimpse of the vessel itself. The flood had receded 


\section{At the Meeting of the Waters}

somewhat, and where the current had flowed strongest across the fields, the land was much furrowed and was scattered with drift rubbish. This rubbish varied from cornstalks to vast tree trunks with roots and broken branches attached.

The levee and the rough, half-wooded land along the river serve the local cattle for pasturage, or "range," as the people themselves say. The water had been so high and the season so backward that the creatures had been having hard fare, and they were as thin and gaunt as scarecrows, and their hair was tangled full of cockle burs. They licked up the grass and weeds on the levee and wandered over such of the last year's cornfields as were not flooded. When there was bare ground beyond the backwater the cattle were sure to seek it out. They would go in slow, steady, single file, wading up and down over the submerged ridges, and now and then disappearing all but their heads. The calves followed the rest, even though they had to swim half the distance. Once out of the water the creatures would begin to crop the tufts of grass that had succeeded in thrusting through the mud, and sometimes would nibble the leaves from the trees.

The levee on which I was walking was quite impressive, it was so immense, so regular, so unending. Approached sidewise it made a considerable hill to climb over, while the top was a much-used highway deeply marked by cattle and pedestrians and occasional horse- 
I 56 Highways and Byways of the Mississippi Valley

back riders with a broad hard-trodden footpath. On the landward side the fields were large and smooth, and looked fertile and well-tilled. Here and there were pleasant homes, none of the dwellings fine, but as a rule cosey and clean, with vines and shrubbery and shade trees growing about them.

Of course there were the ruder and less orderly homes, too; and in particular I noted a negro cabin on the edge of the levee that was a real marvel in its way. One end had settled down off its blocking and had slewed the whole structure out of shape, opening cracks, twisting floor boards, and tilting the porch roof the wrong way. I tried to find out what had happened to the house, but could only learn that it had been just like that a long time, and that the owner was intending to tear it down, so there was no use attempting to better it.

Not far away, on the other side of the levee, I stopped at a farmhouse to talk with a sunbonneted white woman who was making soft soap in the yard. She had a fire with a great black kettle over it and said she was "bilin' the lye. It has to bile slow all the morning," she continued, "till it's very strong. Then I put in the fat I've saved - trimmin's of meat sich as we don't eat, pork rinds, and the cracklin's that we have left when we are trying out lard. After the fat is in I have to stir it every little while with a paddle and be careful not to have too big a fire, or it will bile over. So it simmers along till 


$$
1
$$




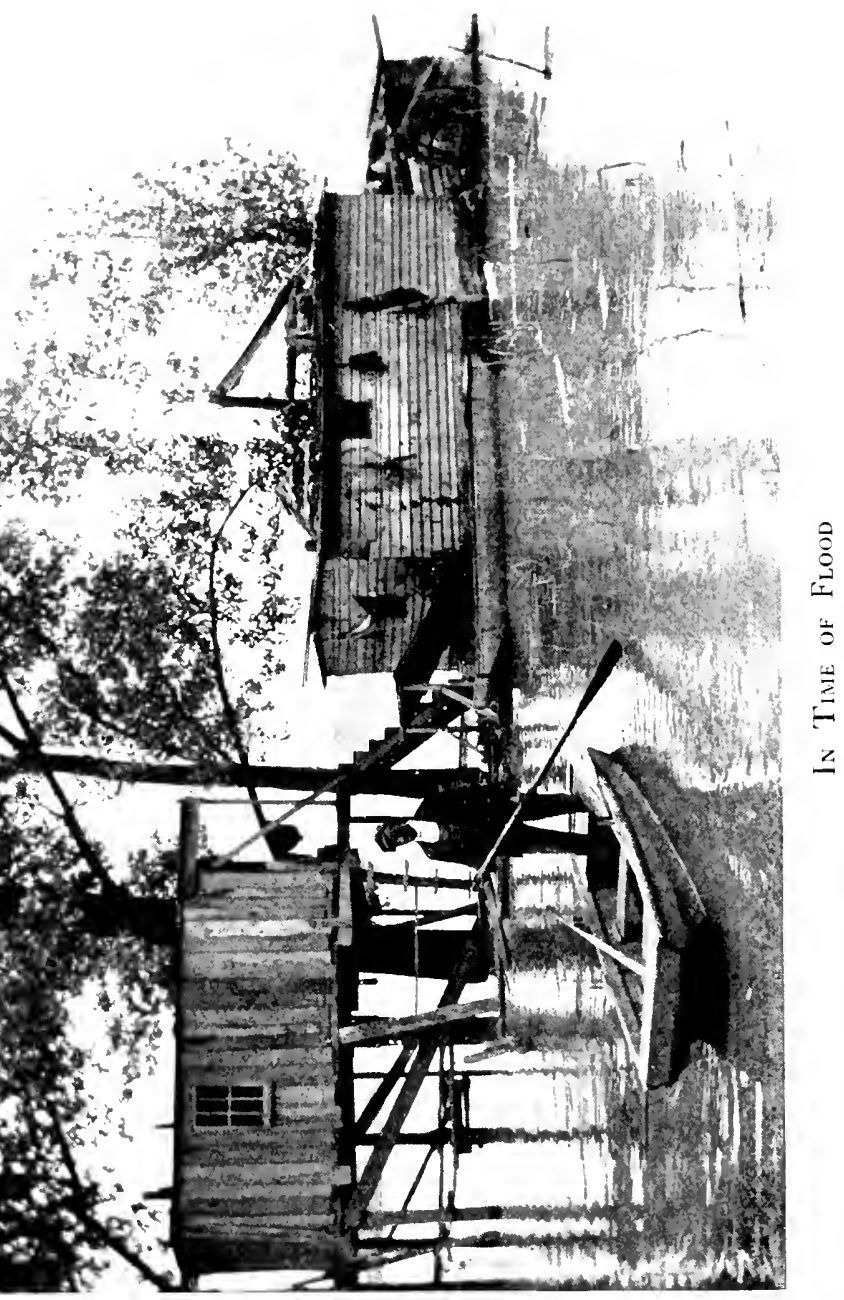


four or five u'clock and is done; and when it's stood to cool over night I dip it out into a flour barrel. If the soap is all right it's thick like jelly, and I'd much rather have it than the soap you buy. What I make in this kittle will run me a year."

I could see that the recent flood had been up in the yard; but it had not reached the house. "The floods are the worst thing there is about this country," the woman declared. "Now this year the big slues in the fields won't dry out all summer we've had sich an overflow, and we couldn't git our garden broke up till two days ago. I think potatoes had ought to be planted in the dark o' the moon to do real well, and a heap o' people talk thataway; but with the water comin' up hyar like it does you have to plant when you can. I was raised in Kentucky, and it always seems to me we got kind of a queer climate hyar. Sometimes it turns in pretty dry, and then ag'in thar's too much rain. I never heared what 'twas like till I come hyar, and I allow I'd 'a' stayed in Kentucky if I'd knowed."

When I returned to Cairo it was evening, and the flooded bottoms were vocal with strange pipings, gutturals, croakings, and mutterings. All the swamp creatures were rejoicing in the abounding water and were singing their weird songs of contentment and love.

Note. - Cairo can hardly be called an ideal town for tourists, and yet a day or two can be spent there with profit and pleasure. One should see for oneself the meeting of the two giant rivers, and should get 


\section{Highways and Byways of the Mississippi Valley}

acquainted with the loiterers and workers of the waterside, and with the houseboat folk, and should go for a ramble on the levees.

The town did not especialiy interest me aside from the features I describe; yet I do not claim to have done the place full justice, for I dwell only on certain picturesque characteristics that impressed me in my casual wanderings. When this chapter appeared as one of a series of articles published in the Outing Magazine, the Cairo Bulletin commented on it in a long editorial headed " Cairo Maligned Again." The Bulletin says that Charles Dickens, in his famous travels in America, "influenced by a severe attack of the influenza, proceeded to void his wrath" on Cairo, and it has ever since "been fashionable by a certain nondescript class of writers" to copy his thoughts if not his words. "Young authors whose works do not command attention without the thin yellow line of sensationalism, and who fail to realize that the immortal novelist succeeded, not because of his abuse of this city, but in spite of it, are disposed to fall into the same error which caused Charles Dickens such keen regret during the late years of his life."

The Bulletin thinks I ought to have devoted more time " to an examination of the religious, social, and commercial life of the city." It adds that if the author "had embraced the opportunity to attend divine services in the city at any one of the dozens of churches, he might have felt in a much less libelous frame of mind. If Mr. Clifton Johnson will take the trouble to repeat his visit to this city, giving due notice of his expected advent, he will have quite as much reason as he did upon the occasion of his first introduction to the community for reporting that 'the place is probably not charming at any season.',

After all, doesn't the editor's closing hint of tar and feathers, or whatever the forms of personal violence may be that he had in mind, savor more of the dominance of saloon influence in his city than of the many churches he mentions? Cairo undoubtedly has a better side than that I particularly describe, but it has also a worse side if this bigoted editorial is a fair sample of the tenor of its citizens' minds.

The pith of Charles Dickens's reference to Cairo is as follows : "At 



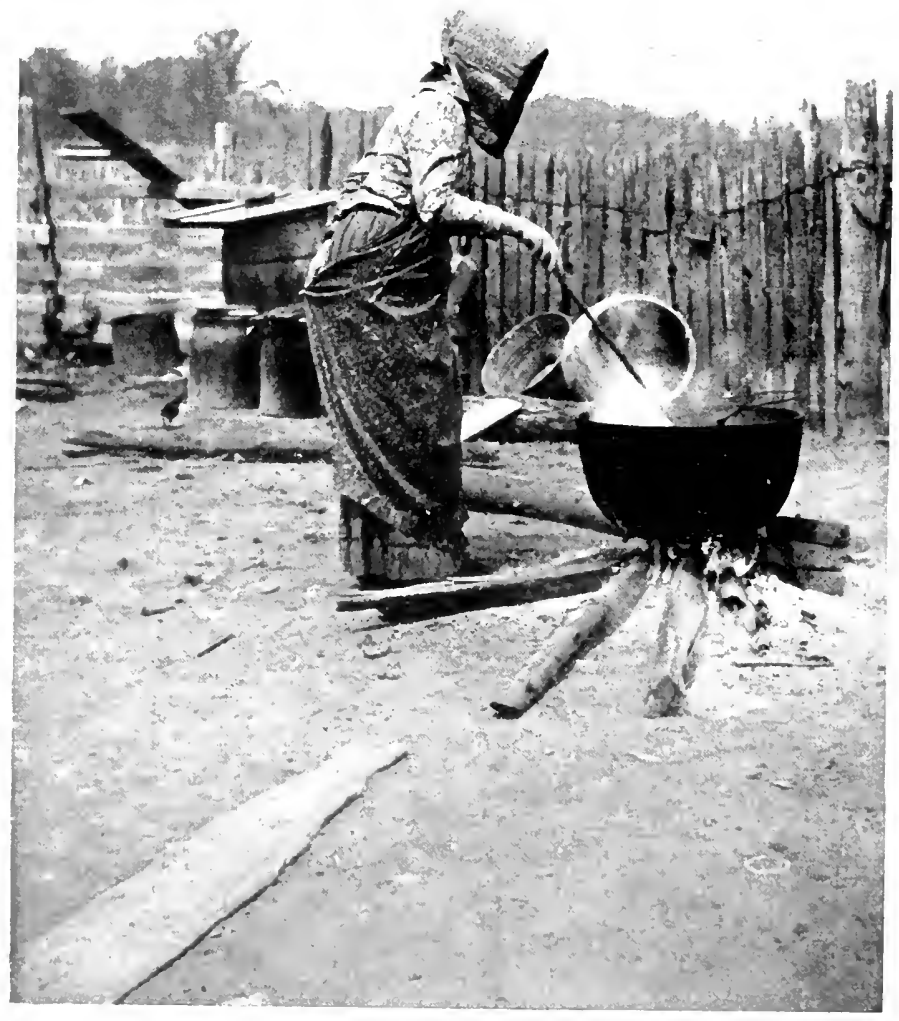

$S O F T-S O A P$ 
the junction of the two rivers, on ground so low and marshy that at certain seasons of the year it is inundated to the housetops, lies a breeding-place of fever, ague, and death. A dismal swamp on which the half-built houses rot away; cleared here and there for the space of a few yards, and teeming then with rank, unwholesome vegetation; a place without one single quality in earth or air or water to commend it - such is Cairo." 


\section{IX}

MARK TWAIN'S COUNTRY

ARK TWAIN has been a good deal of a wan-
derer, but the region that is peculiarly his own
and that his nemory lingers over most fondly is the land of his boyhood. Again and again he recurs to it in his books, and portrays with rare vividness the old life he then knew. His home was at Hannibal, Missouri, a loafing, out-at-the-elbows, slave-holding river town. As matters were then, the Mississippi was far more interesting than anything else to the inhabitants, and the big steamboats arriving daily out of the mysterious unknown of the North and South never failed at their approach to rouse the town from its usual torpor into alert activity. The world lay whence they came and whither they went; but now they are infrequent, and their work is done by the prosaic railroads.

Hannibal has grown a good deal in the last fifty years, but here and there the old lingers amidst the new, and surrounding nature in its wild hills and glens is essentially unchanged. Great ragged bluffs rise successively along the river front, and the loftiest height of all, with an altitude of three hundred feet, almost overhangs the 
heart of the town. This is one of the "Lover's Leaps" you find all along the river; for wherever a particularly bold cliff rises above the stream it has been given the title mentioned and a vague legend has grown that long ago some lovesick Indian jumped off the height to his death. At any rate these bluffs are quite appropriate for such a performance. About Hannibal they slope away from the stream in green, tree-dotted pastures, for the most part. On the hills inland are scattered farmhouses and many orchards, patches of forest, fields of grass, corn, and small fruits. There are clear streams in all the hollows, and so much variety everywhere in the landscape that the region seems a boyhood paradise, unfailingly stimulating to the youthful imagination and full of possibilities.

The house the humorist lived in still stands and is much the same as it always was - a stumpy, twostory, clapboarded dwelling close to the sidewalk. It is just off the main street snugged in among other similar buildings. The senior Clemens had a printing shop upstairs in the $\mathrm{L}$ of the house, and as there were several children the living rooms must have been pretty well crowded.

"All the family was the nicest people you ever saw," I was told; "but they were very poor and the father died bankrupt when Mark was twelve years old."

On the next street lived "Huckleberry Finn," whose real name was Tom Blankenshipp. In the books this 
I62 Highways and Byways of the Mississippi Valley

lad turns out to be quite an admirable character, but in actual life he and all his relatives were a very rough lot, and when he left town it was to go to the penitentiary. The author's descriptions of Huckleberry's father fit the person who was "the town drunkard - old man Finn." His end could hardly have been more tragic even in fiction. He was locked up one night in the calaboose, and in lighting a match to have a smoke set fire to the building and was burned to death.

The Huckleberry Finn house was always rude, but it has not yet succumbed to either age or chance, and its ruinous, unkempt antiquity is quite worthy of its associations. 'Two or three negro families now live in it, and I made the acquaintance of one of the women inmates who was sitting out in front lunching on bread and a dish of greens. Once in a while she gave a bit of the bread to her little dog that hovered about expectantly. "I'd be eatin' indoors," she remarked to me, "but it kind er wet in dar sence dis yere big rain yisterday.'

There were holes in the roof, and I asked if the water came down through from the upper story.

"Oh, no, honey," she responded. "It flowed right in de door. I live at de bottom er de house three steps lower dan de sidewalk, an' de water have an easy chance to git in; but it mos' dried away now."

"This is the Huckleberry Finn house, isn't it?" I inquired. 


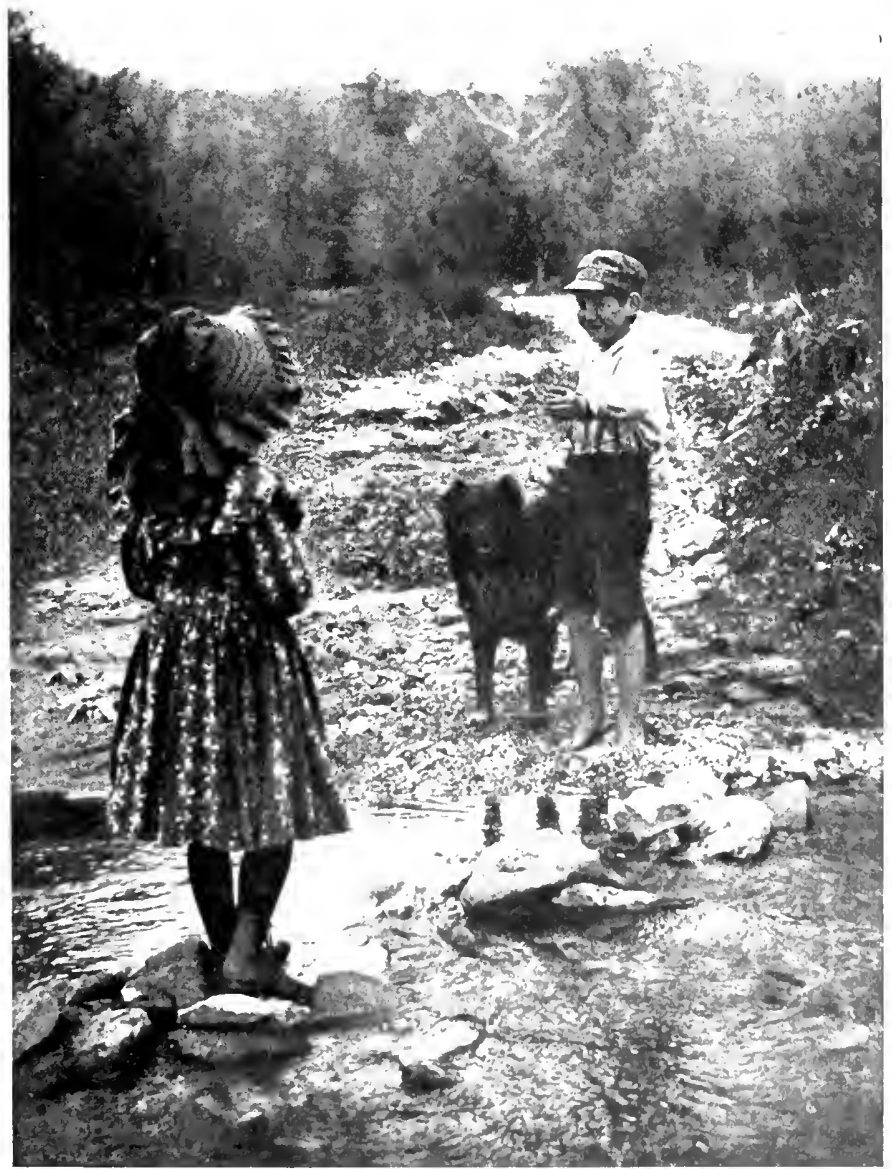

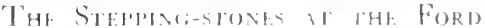



"It sholy is," was the reply, "an' las' year Huckleberry Finn and Mark Twain both was hyar to see it. Dey come togedder in a two-horse coach, an' dey each one give me a quarter."

"Yo' doan' know nothin' what yo' talkin' about," said an irritated male voice from inside the lower room. "Huckleberry Finn is daid long ago."

"No, he ain't," was the woman's reply. "He was hyar las' year an' give me a quarter. He was a little dried up ole man and he had whiskers an' look some like Santa Claus. You seen Santa Claus picture, ain't you, mister? Mark Twain is a heap bigger'n Huckleberry Finn."

"He's daid, I tell yo'!" said the voice indoors in gruff anger.

From a window upstairs a dishevelled young colored woman was looking down. The window-glass was mostly gone, and she had her head thrust through a hole left by a missing pane and one arm through a similar opening just below, so that she could rest her chin on her hand; and she made a very grotesque sort of a tableau. The woman below referred the matter in dispute to this looker-on, who said it was Huckleberry Finn that called with Mark Twain, and no mistake. Her response maddened the man inside past endurance, and he began swearing and stamping about and finally slammed the door.

The woman with the lunch rolled up her eyes depre- 
I64 Highways and Byways of the Mississippi Valley

catingly. "My man git plumb crazy over his own mistakes," she declared. "He doan' know he wrong when I tell him so, an' when all de neighbors tell him so, too. God has sent a judgment on me for marryin' dat man. I gwine go away to St. Louis an' jine a show if it ain't nothin' but de hoochy-koochy!"

The part of the town I was in lay at the foot of a steep and lofty hill with little homes clinging to it, and here and there stairways and zigzag paths. Farther north were other hills and among these the boys used sometimes to dig for treasure, and here, according to the Tom Sawyer book, was a haunted house. Even now there is a "Ghost Holler." I was told about it by a woman who lived near by. "It's a very lonely place," said she. "It's shady and awful deep, with high rocks on both sides, and it's always damp, and the ferns grow there. It looks ghostly - it really does; and some people say they see things. I know the children have been in there and heard strange sounds and come running home they were so afraid. Folks claim some one was murdered in that holler a long time ago."

The woman was standing at her garden gate, and I had interrupted her in the midst of a chat with another woman, her nearest neighbor. "Speakin' of Ghost Holler," said the latter, "reminds me of when Will and I was first married. Don't you remember, Mame, the old house in the west part of the town we moved into? People told that the house was haunted by a woman 
who had died there, and my Aunt Isabel, when she found I was goin' to live in the house, she give me a talkin' to. She said, 'Don't you do it. You'll never have no peace. That woman comes back nights and she takes the tin pans and the dishes and makes such a rattlin' no one can't sleep.'

"I got so nervous over what she said I told Will I wouldn't go there. But he laughed at me, and he said Aunt Isabel was superstitious or she wouldn't 'a' repeated such nonsense; and he said once when he was a boy and was out in the dark he see a big black thing in the woods that seemed like some terrible monster, and he thought to himself, "Maybe it is, and maybe it ain't. If it is, I'm a goner anyhow whether I run or not, and so I'll just find out.' Then he went right to it, and it was nothin' but a half-burnt stump. Ever since that time, when he sees anything strange in the dark he jus' goes straight to it, and he says he wants his children to do the same. He does hate raisin' children up cowards. Well, we went to the house he'd rented, and my pans and things stayed quiet on the shelves same as they would in any house."

The hill where the boys used to dig for treasure with most enthusiasm, expecting to find "a brass pot with a hundred dollars in it, or a rotten chest full of di'monds," was two miles north of the town up the "river road" that creeps along the verge of the stream. According to tradition, the old Spanish explorers buried 
I66 Highways and Byways of the Mississippi Valley

vast riches there. Adults as well as youngsters have delved after the fabled treasure, and the search has not even yet been abandoned; but if the scrubby pasture height holds any golden hoard in its stony soil it has thus far kept the secret well. Another attraction that the hill has is an Indian mound. This is on the loftiest crest of the bluff, an impressive spot commanding an immense sweep of river and valley. The mound is eight or ten feet high and has a base some twenty feet across. These mounds are common on the uplands, but they have all been dug into and pillaged by the whites.

The most notable of the Tom Sawyer adventures occurred in a cave three miles beyond the town in the other direction. The cave entrance is in a low valley to which a long winding road descends from the main highway on the hills. This road has been abandoned, and I found it gullied by rains and growing up to bushes, and the bridges across the brooks had rotted out and fallen in. But I contrived to get along until a big black storm came swooping across the sky. Luckily I was now near the bottom of the valley, and I soon came out of the woods into a clearing and saw a house not far away. Great drops of rain were beginning to pelt down out of the gloomy sky, and I ran. I did not escape altogether; but the worst of the storm came afterward and was mingled with a dash of hail.

The house was empty when I entered it. However, 


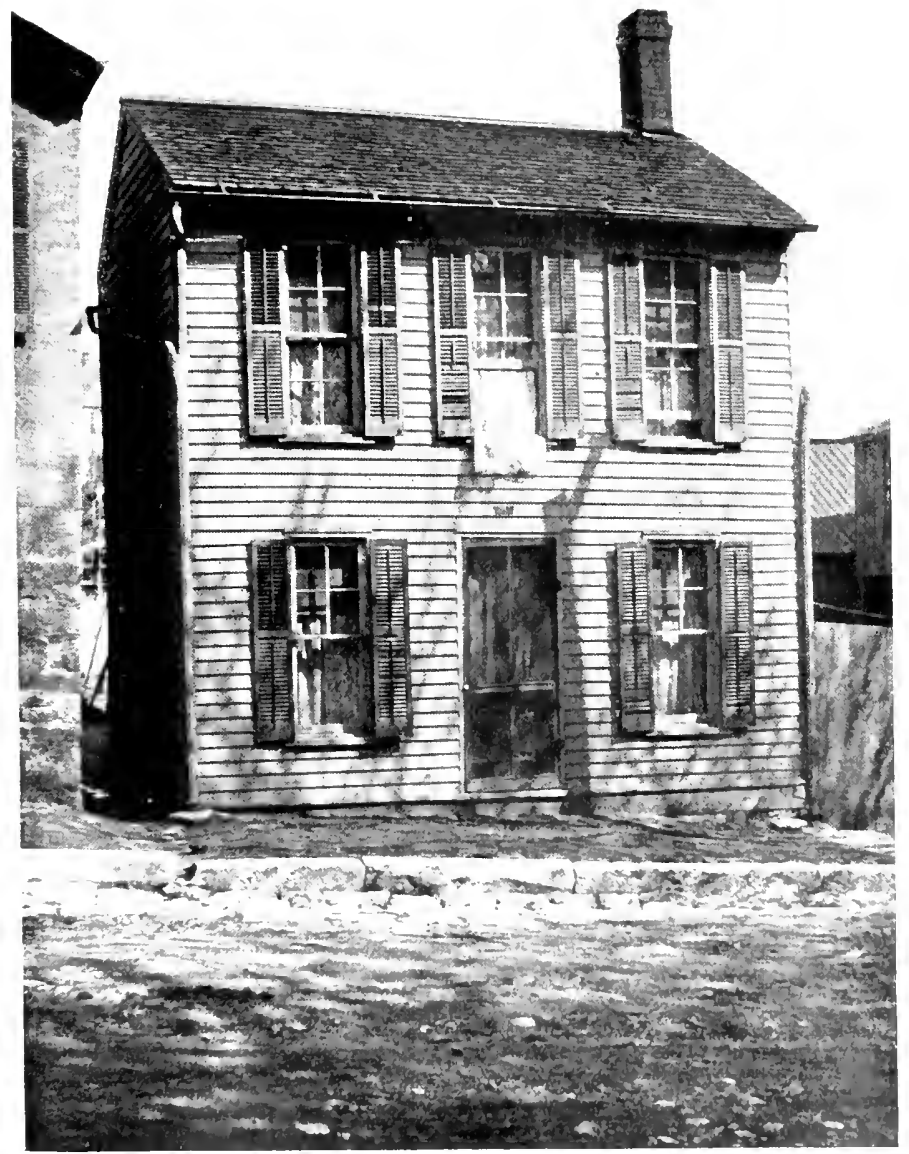

Mark 'Twaln's Borhone Hone 

a few moments later a woman hurried in with five children. She said: "They been playing down to the creek. I can't keep 'em away from there, talk all I will. Do you see that there blanket out on the line? I've washed it three times to-day, and every time the line has broken and let the blanket down in the dirt. Now, it was jis' gettin' tolerable dry, and see how the rain is soakin' it. I never was so discouraged in my life. We moved here a month ago, and we ain't had nothin' but rain since. We've put in our garden, but seems like the seeds was all goin' to rot on us before they can come up. I don't know what's got into our climate, it's so different from what it was when I was a girl."

The children for a time looked at me while their mother talked, and then glanced around to find other amusement. Presently the mother exclaimed sharply, "Come away from that cat, Harry!" and turning again to me remarked, "I ain't much stuck on livin' in the country."

The boy had not been quelled, and the cat was making audible protests at his treatment. "Harry," said his mother with more energy than before, "leave that cat alone"; and she continued half to herself and half to me, "What does make a youngone keep on a-doin" a thing thataway after you've tol' him to quit?"

Two of the children stepped to the door and held their hands out to the rain. The mother called them 
168 Highways and Byways of the Mississippi Valley

back and then observed: "I don't want 'em wet because they got the whoopin'-cough and might be made sick. They ain't havin' it powerful bad though. They don't whoop. They jis' cough hard an' gag an' throw up; but throwin' up is a good sign, you know."

She gazed out of the window. "There's too many hills here," said she. "It's all so up and down that it's discouragin' to look at it. I don't see why any one should want to live in Missouri. I reckon Illinois is better; but law! I might not think so if I was there.

"Until late years my husband always lived in the town. Me 'n' him was raised on the same street; and when I was young folks I used to say I wouldn't marry a countryman, no matter how rich he was. One of our best friends is a man that is a farmer and always has been. We was still livin' in town when we got acquainted with him, which was jis' after we was married; and he said if he'd seen me sooner he'd 'a' married me instead of his own wife. I turned up my nose at that because I wouldn't have looked at any one but a city man for a husband then; and yet I might as well have taken a countryman that knowed something as a city man that didn't know anything. A countryman understands how to do everything about crops and buildings and tools; but a city man when he's put out on a farm is mighty unhandy. Oh, it's so dead here from what I'm used to!"'

Now the storm was past and the sun was shining forth 
on the wet earth and the dripping trees, and I resumed my walk. The woman told me the cave was "sort o" on the bum," and I found the evidences of its being a run-down pleasure resort quite apparent. Near the entrance were a few shabby buildings including a pavilion. The passage into the earth had been roughly enlarged, and a slatted door, whacked together by some tinkerer, had been put up. I joined a party that was just going in with a guide who distributed candles and then led the way. The cavern honeycombs the earth with several miles of devious and tangled passages, and it was among these passages that Tom Sawyer and Becky Thatcher were lost on that Saturday of the picnic, and they did not get out until Tuesday afternoon. The walls of the cave are a monotonous gray, and the channels never have width or height enough to be impressive; but the age of it all, the silence and the gloom, are not easily forgotten. Mostly, the interior is quite dry, but in certain spots the water drips through, and in one of the little side channels is a crystal-clear pool at which every visitor stops for a drink. Except for the smudgy and odorous candles the air is perfectly pure. There are other caves in the hills, and a resident of the vicinity mentioned to me that, "Some of 'em have got satelites in 'em"; but only the Mark Twain cave has been made accessible to the public.

Our guide had read Mark Twain's works and was quite capable of discussing them. "'They're entertain- 
Ito Highways and Byways of the Mississippi Valley ing." he said: "but they"re mostly fotition. Mark was here last rear. I was expecting to see a great tall man, and ret he's no larger'n you or me, and just an ordinary man to look at. He's got a big reputation. though - probably because he's kind of an oddity something on the ancient order I might say. He has a rambling disposition. and I expect it's his nature to be uneasy and to think some other place would suit him bettern the one he s in - same like a tramp. He's livin in Italy just at fresent and writin the history of the world so far as he knows it."

The author's birthplace was Florida. a lithe romn up Sale River. twenty or thiry miles awar. I dedided to see it. but the railroad does not go nearer than a halidozen miles and I walked the rest othe distande. It was a prettravage sort of a highay that I ravelleda chan of ruts and ridges mud and pools. It looked as it it had been ploughed by Satan and his imps to plague mankind. The low spots were a wild mixeure of stiss and stones and liquid lay and how a team could get along and keep right-side up was a mystery. In places I was puzzled what to do mystivand once or wice I climbed along on the ience. I grew tired of the monotony ot the rolmo landsane. There was a constant succession of houses and fenced helds and grazing herds: but the houses were far apar and the relds very large and the roak distressingly straght. I struggled on until I came to Sal River. and there 



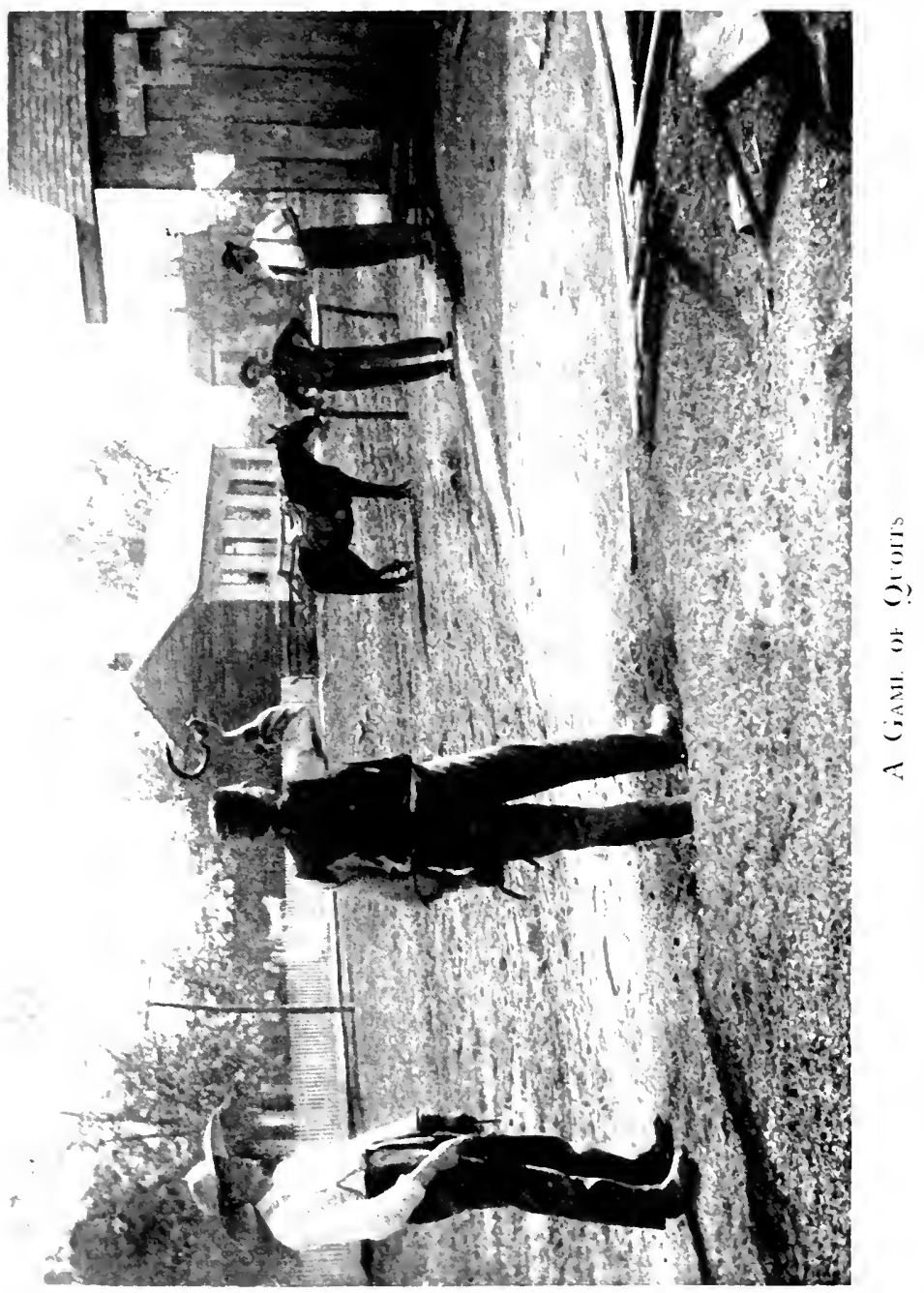


beside the swift, muddy current I made the acquaintance of two old ladies sitting on a log fishing in great quiet and contentment. They had thus far caught only one fish; but they had the enticement of hope to cheer them; and apparently the companionship of each other and the stream and the fresh leafage of spring putting forth on the banks and the songs of the birds were happiness enough, fish or no fish.

On the crest of the hill beyond was the village, a primitive hamlet well away from the busy world, and seldom stirred from its placidity. Its visible life, as I saw it, consisted largely of loiterers around the store porches and numerous wandering pigs on the streets. These pigs had no qualms about lying down to sleep in the middle of the highways, and their miry rootingplaces were everywhere. The majority of them belonged to the proprietor of the village drugstore, and it was his habit to feed them directly in front of his place of business.

I found lodging at an old-fashioned farmhouse. The floors were covered with rag carpets, some of which were quite new and calculated to put a rainbow to shame with the variegated brightness of their stripes. Rag carpets are the standard kind throughout the Missouri country among sensible people of moderate means. In a back shed of one of the Florida dwellings was a carpet in process of weaving, and before I left town I went in and watched the work. The woman weaver said 
172 Highways and Byways of the Mississippi Valley she earned twelve or fifteen dollars each spring and fall. She charged ten cents a yard and had to work very persistently to do five yards in a day. "It's hard on your clothes doing this weaving," she added, "and I wear out enough in a season to make a rag carpet for myself out of 'em.'”

It was very pleasant that first evening at the old farmhouse after the day's tramping to sit on the back porch and rest. The robins carolled in the trees, the swallows soared and twittered, the Bob Whites called in the distant fields, and the odor of apple blossoms filled the air with gentle perfume.

My landlord and his wife were old like the house they lived in, and their recollections went back to pioneer times. After supper I had their company on the porch, and also that of a few mosquitoes. "We don't have the mosquitoes the way we used to have'em when this country was first settled," my landlord remarked; "but you'd find plenty yet down in the bottom lands. There ain't much water up hyar on the hill for 'em to hatch in."

"No," said his wife, "though there's a right smart of 'em come from our water barrels, and I've always heard they're a heap mo' friendly raised thataway.

"When I was a little girl," she continued, "hit was all woods around hyar for four or five miles north and south of the river - oak and wa'nut, cottonwood, 
ellum-everything. We didn't have any wire fences then. They was all of split rails. Our first-class timber is pretty much gone now. We got plenty of wood to keep our houses warm, but we don't cut down any good trees and burn 'em on the ground to get 'em out of the way, as we did once. Wood's worth something. Why, we took up a rail fence last winter was a year ago, and sold hit for firewood and got enough to buy a wire fence to take hits place."

"I've got that fence around my cornland down by the river," said the man. "The river put a terrible sediment on the bottoms this year - more than I've seen in any fresh for a long time, and we'll have a powerful crop. Most of our land ain't very good until you get out on the prairies beyond this strip that used to be wooded; but the first settlers didn't take that up because hit was all covered with great coarse grass, and there was what they called the greenhead fly on the prairies that you couldn't get along with nohow. Them flies would light on your horses like a swarm of bees and bite and suck blood so your horses would be unmanageable and you'd have to race 'em for timber land along the nearest crick. When the settlers began to cultivate the prairie they had to plough nights to git shet of them flies. The flies was raised in slues and stagnated water, I reckon, and after the grass was cut and the land opened up to the sun the way hit was when the settlers begun 
I74 Highways and Byways of the Mississippi Valley

to come pretty thick, the hatching places was dried up or was drained away and the flies jis' naturally disappeared."

I mentioned seeing an old ruin of some sort on the river bank. "That was a water mill," explained the man. "Back in I 840 we had two hyar, and the farmers would drive from twenty-five miles around to get their grain ground. They'd put on all the wheat they could draw with four horses and come twice a year. Often, there'd be wagons waiting ahead of 'em and they'd stay two or three days befo' hit was their turn. While they waited they'd camp out. I've seen 'em camped around the mills most as thick as the campers that used to come to our picnics."

"What picnics were those?" I asked.

"Until late years we been having a picnic in August every year," said my landlady. "All the people in the village and round about helped to organize hit, and we'd select a place in the bottom by the stream and set up some posts eight or ten feet high and put crosspieces on the tops and lay on bresh so as to make an arbor about fifty feet square. Thousands of people would come, and some of 'em would be from forty miles away and would start the day before. These distant ones would get along that afternoon or evening with their buggies and surreys and wagons, and then they'd camp. Everybody brought food, and on the picnic day hit was all turned over to a man in charge, who'd make one big 



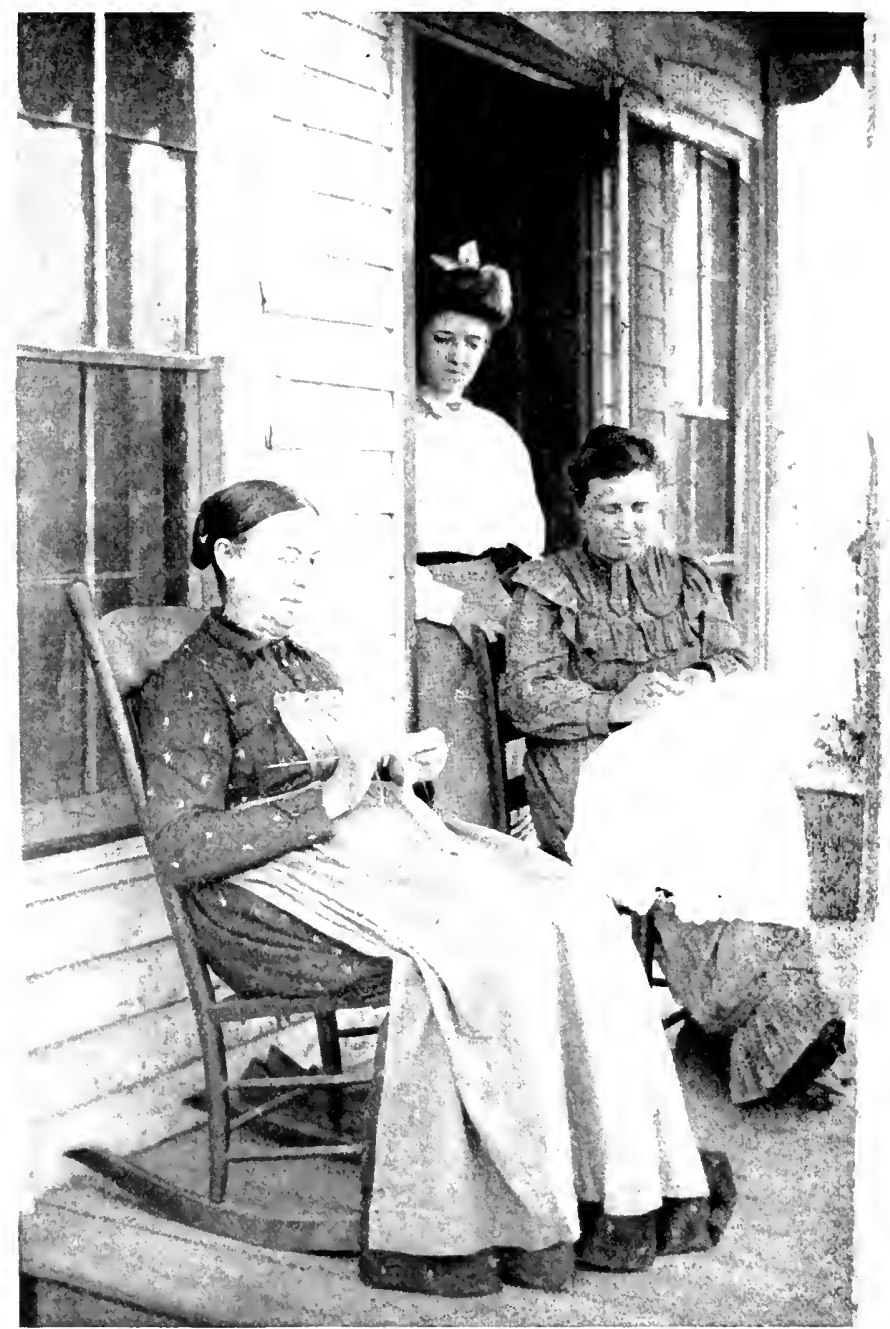

Aftarnoon Comfori 
spread of hit and invite the people to come up and help themselves."

"And there was plenty of grub for the whole crowd," added the man. "They wouldn't eat nearly all of hit. We had speeches and songs, and in the arbor there was fiddling and dancing till late in the night. Around the sides of the arbor we fixed planks on blocks so the ladies could sit down, and if we'd got the arbor high enough so the bresh didn't tech a feller's hat we was all right. Ah, the picnic was a great thing; but she's run down now." "This town has changed a good deal since I can remember," remarked the woman.

"Befo' the war," commented the man, "we had niggers here as thick as blackbirds; but now thar are mighty few left. We were all Democrats then, and if a New England man that was a Republican come here and stuck to his principles he might as well 'a' been a cat in hell without claws."

"I shall never forget the war," observed my landlady. "We had quite a little fight right hyar in the village. Some Federal soldiers was chased by a party of Confederates, and they all come gallopin' into the village jis' at daylight, and the Federals got into the schoolhouse. The guns begun poppin' and we was all scared most to death. I and my folks was in our summer kitchen, and my mother tol' me to keep away from the window or I'd get shot; but I wanted to see and I looked out. Two Confederates was killed and I saw 
176 Highways and Byways of the Mississippi Valley one fall from his horse. The soldiers was always raidin' through hyar, one side or the other, and my mother she didn't want her silver spoons stolen; so she wrapped 'em up in a towel and dropped 'em into a barrel of feathers. But some of the Federals come pokin' around one day and they found 'em, and they laughed and handed 'em to her and tol' her to keep 'em where they belonged."

"We were all secesh," explained the man, "and helped off our bushwhackers as much as we could. That made the Federals mad. I know once, when they'd been on a chase that didn't succeed, the Federal commander rode our streets east, west, north, and south, and shouted he'd jis' devastate this country for ten miles around if we didn't quit givin' the enemy information."

"One man they wanted to get was ole man Hickman," my landlady continued. "He was a terrible Southern man and a spy. The Federals surrounded the town once and 'most got him. They come within six feet of where he was hiding in a little hollow among some bushes."

"I bet his breath was short then," interrupted my landlord.

"He said he didn't breathe at all," responded the woman. "But, come night, he crept away gruntin' to imitate a hog so they wouldn't be suspicious if they heard him movin'." 
"People was mighty mean in time of the war," mused the man - "though they're mean enough any time, as fur as that is concerned. They thought nothin' of droppin' in on you with ten or fifteen horses to feed and not payin' a cent; and they was always on the watch to find out whether you was helpin' the other side. I tell you it made a fellow's eyes bug out to have one of their shinin' guns poked in the window at you unawares."

The twilight was deepening into gloom and the air was growing chilly. Overhead the swallows were taking their last flights. I stepped out into the yard to look at them. There they were, hundreds of them, flying all in unison in a vast circle with wonderful swiftness. At one point this winged ring was directly above the cavernous chimney, which thrust up from the heart of the house, and the birds, after making many feints as if they would dart into the orifice, at last began in earnest to disappear within it, each dropping with such suddenness as almost to deceive the eyes. The circling continued, but with lessening numbers, till the last feathered meteor was gone. The chimney adjoined my chamber, and that night, whenever I awoke, I heard from inside it a light rumble of wings and intermittent twitterings.

Morning came. A brisk breeze blew, and my landlord said, as he sat down to breakfast: "Well, I do despise this wind. Hit kind o' makes me uneasy. But 
I78 Highways and Byways of the Mississippi Valley

they say we don't have any such broadcast blowing as they do out in Kansas. Two fellers from there was hyar one day and the wind was blowing so I couldn't hardly keep my hat on my head, and I was speakin' of hit, and they said, 'If this don't suit you, don't never go west. We'd call this a very ca'm day. Why,' they said, 'where we come from, if you put your hat on the windward side of the house, the wind will blow so hard and steady hit'll stay there all day.'"

"I can get along with most any wind but a cyclone," said his wife; "and I feel thankful we got a cyclone cellar handy to the back door. I'm always on the watch when we have a day that's extry warm and still."

"Hit's a bad sign, such a day, if you see a black cloud raisin' in the west," said the man. "Last year a cyclone passed within sight of us. We watched hit and kept all ready to go into our cellar until hit got too far over to do any devilment hyar. Hit was only a mild away, and how hit rattled - my, what a fuss thar was! Forty old wagons on a rough road wouldn't begin to make as much noise. Thar was a funnel an' what seemed to be smoke bilin' up like from a locomotive. My sakes! I never saw so black a smudge, and down low was a queer, yellow glimmer. Hit made a track about one hundred yards wide and hit taken everything before it. Trees a little decayed hit would twist off leavin' only a stump, and trees that was sound hit would jerk right up by the roots, no matter how big 


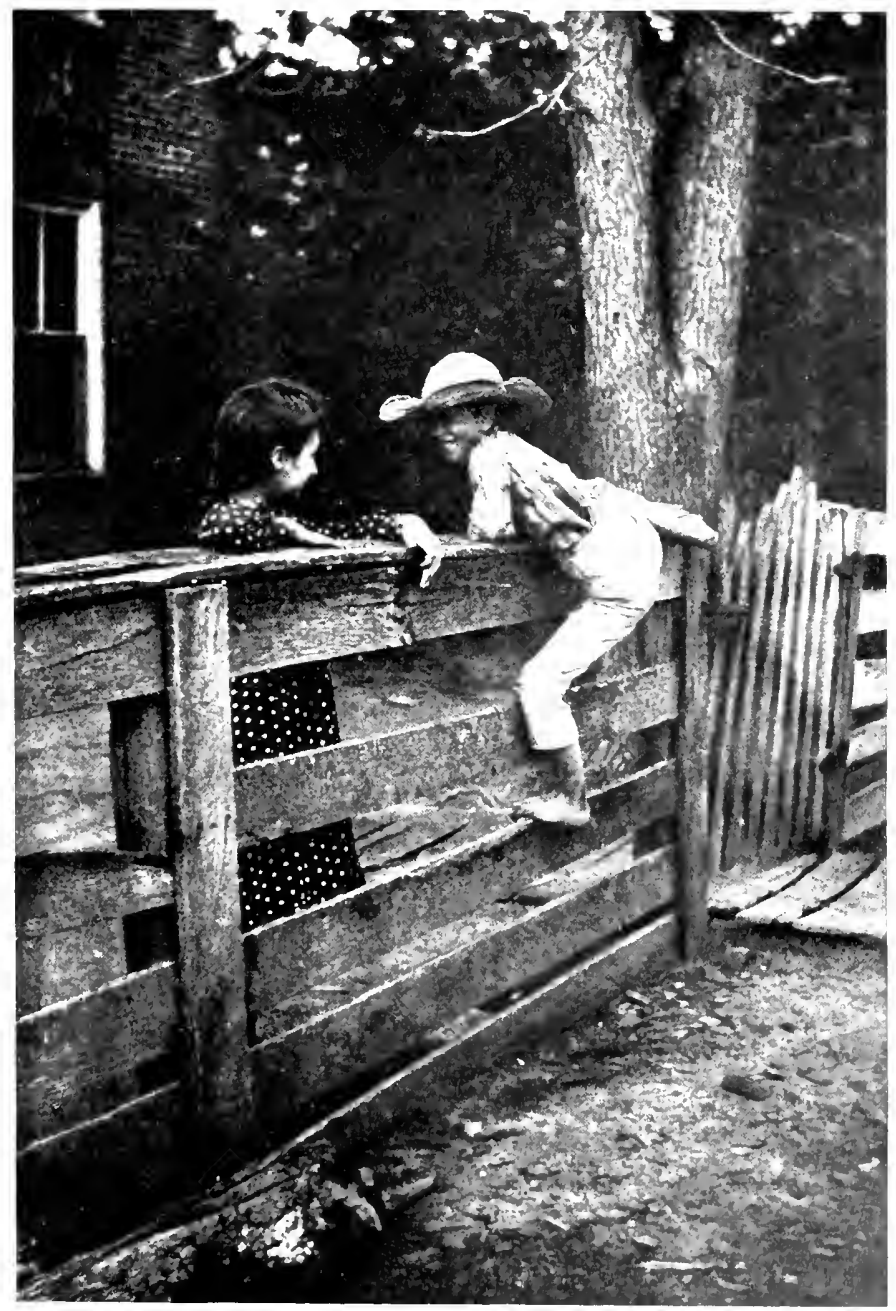

\リ1: 

they was. Hit cleared everything right off down to the ground, and I been tol' hit struck some hens and took their feathers off jis' as clean as you could 'a' picked 'em off yourself. I heared tell, too, about a farmer who had a lot of corn stored in a bin. At one side of the bin was a knot-hole, and the cyclone caught that corn and drove the cobs all through the knot-hole. That scraped off the kernels and left 'em in a nice heap inside the bin. One place thar was a man settin' in his house, and the wind tuck that house right up and busted it plumb to pieces, but left the floor and the man settin' thar in his chair."

All this was quite interesting; but what interested me most during my stay in Florida was to meet an old lady eighty-three years of age, who remembered distinctly when the Clemens family were residents of the place. The father was for a time a merchant here and built a $\log$ house to live in. While this log dwelling was being erected, the family occupied a little tworoom frame house, and in the kitchen of that house Mark Twain was born, November 30, i 835 . The house still stands, though now vacant and rather ruinous. The family moved to the log dwelling when the baby was three orfour weeks old. That survived until recently, but during its later years no one lived in it and people got in the habit of taking away bits of it as Mark Twain relics. "Why, they tore the house pretty near to pieces!" said the old lady. "They'd carry off brick- 
I 80 Highways and Byways of the Mississippi Valley

bats from the chimney and pieces of glass from the windows and splinters of wood from the doors and other parts, until they'd got about everything but the logs.

"Mr. Clemens took his family to Hannibal when Mark Twain was still a very little boy, and since the boy has growed up he ain't been here more'n once or twice. He's famous - and yet I couldn't see that he was different from most folks, except he had long hair and wa'n't very neat. I've read his travels some. They're light and trashy; but they're jovial, and I suppose that's what people like about 'em."

When I returned to Hannibal I met other old-time acquaintances of the humorist. According to two ancients whom $I$ interrupted in an endless series of checker games at the back of a store, Mark Twain is "the most overrated man in America. There's about as much truth in those sayings in his books," I was informed, "as there is in a ten-cent novel. His brother Orion who was a printer knew more in a minute than Sam ever did know; and yet Orion never made no reputation. As a boy, Sam was just like other boys, except he might have been a little slower. He was considered blamed dull, to tell you the truth. It was his peculiar drawl and accent that made him famous, I'll be dogged if it wa'n't."

But another man, one of the author's old schoolmates, discoursed thus: "He was a mighty still sort of a boy. He was distant, and had as a rule rather be by himself 
than with the rest of the boys. Most of us used to like to get in a skift after school and go off fishin'. We'd have our poles and boxes o' worms all ready under the schoolhouse and we'd grab 'em out soon as school was done and go off across the river to the slues and ponds and stay till dark drove us home. But I never ricolect of Sam a-goin' fishin' with us or a-huntin' with us, though he liked to go down to the cave.

"He was a good talker and had the same slow way o' speakin' he's got now. If he was to come along this minute and say, 'Charlie, let's me 'n' you go down to the cave,' I'd know him just by the tone of his voice.

"Whatever he told about, he'd talk so to make sport. He'd tell things in a different way from what the rest of us could, and it sounded funny. He used to tell us tales and we loved to listen at him. His father had a book 'The Arabian Nights' - that no one else had in town, and Sam would get us boys together of evenings and tell us stories from that book, and we was glad to listen as long as he'd talk.

"In the spring of ' 58 he went on the river to learn piloting, because then the steamboats was more interestin' than anything else, and you found people from all parts of the world travellin' on 'em. It ain't thataway now. Our river up here is played out."

The river carried Mark Twain away to new scenes, and he has seldom returned; yet the half-rustic life of the town of his boyhood, and the rugged hills and 


\section{Highways and Byways of the Mississippi Valley}

vales around, no doubt contributed much in developing and furnishing inspiration for his peculiar genius.

Nore. - Any one who likes Mark Twain's books will find Hannibal and the region around keenly interesting. With its varied hills and dales, caves and rude cliffs, the district is worth exploring on its own account, but when you have added to that the sentiment imparted by the famous books which have made it a background for many of their incidents the attraction is superlative. The town of Florida, which I also describe, is not very accessible, and has not even a poor hotel, but if you nevertheless make the visit you will carry away many entertaining memories. 


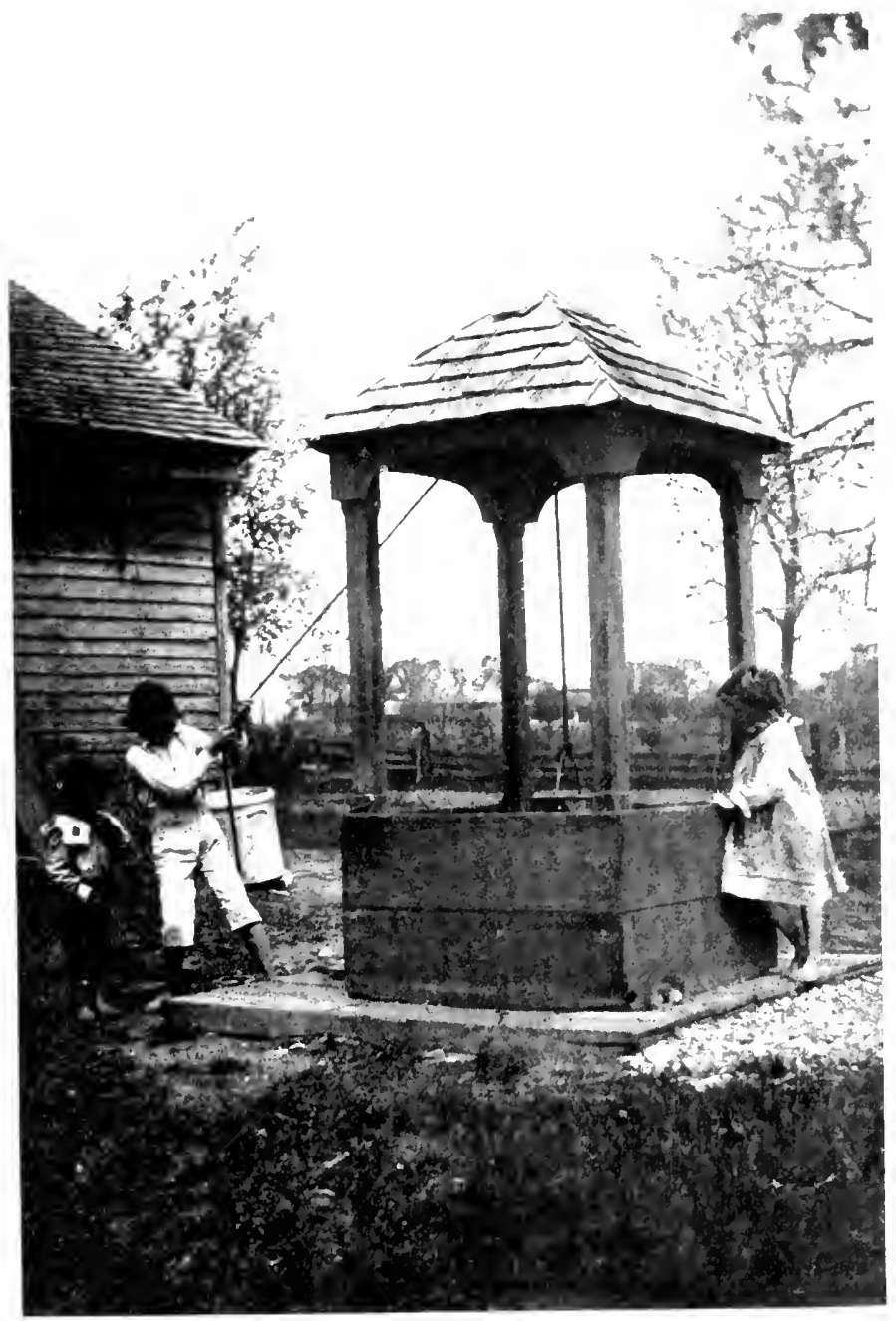

'Th: Prophet's Wha. 



\section{$\mathrm{X}$}

THE PLACE OF A VANISHED CITY

BOUT I823, in western New York, a farm lad,
Joseph Smith by name, began to see visions.
He was seventeen years old. For a long time he had been reflecting on religion, and he was in the habit of withdrawing to secret places and spending hours in prayer and meditation. The region was new and still half wild; the facilities for travel and education were few, and the boy knew practically nothing of the world, and had received little or no schooling. In the visions that came to him in his sleep he saw an angel "with a countenance like lightning," and the house was filled with "consuming fire." The angel told the lad that his prayers were heard and his sins forgiven, and declared that the preparatory work for the second coming of the Messiah was speedily to commence, for which work the boy had been chosen by God to be an instrument in spreading the gospel in its power and fulness to all nations.

This angel visited the farm boy many times, and among other things told him much about the aboriginal inhabitants of America, of how they sank from civili- 
I 84 Highways and Byways of the Mississippi Valley

zation to savagery, of their wars and religion and prophets. The last of the prophets was one named Mormon, who at God's command wrote on thin plates of gold what was designed to be a supplement to the Hebrew Scriptures. After these revelations were duly inscribed, the golden plates were hidden by the prophet on the side of a hill near what is now Palmyra, New York.

Directed by the angel, Joseph Smith, the farm lad, whose home was in the vicinity of this hill, found the plates, and with them a curious instrument which he called "urim and thummim," consisting of two transparent stones set in rims and having some resemblance to spectacles. The characters on the golden plates were in an unknown language; but by looking through urim and thummim, Smith was enabled to understand and translate the ancient records into English.

In I 30 this translation was printed as "The Book of Mormon," and that same year the "Church of LatterDay Saints" was organized and began to grow. From a membership of six it increased in a twelvemonth to over one thousand, and during the next three years the young prophet ordained hundreds of ministers and sent them out in all directions through the country.

Troublous times followed, and the new sect was ridiculed and persecuted, and the believers migrated in search of peace from one place to another. At length, in ${ }_{1} \delta_{3} \&$, the Mormon saints to the number of 
fifteen thousand took refuge in Illinois, where they obtained a grant of land on the banks of the Mississippi. At the spot chosen was a little village named Commerce; but $S$ mith, in obedience to one of the revelations he was continually receiving, changed the name to Nauvoo, which means "The City of Beauty."

Nauvoo was not long in becoming the largest and most promising place in the state; and yet less than a decade passed before it was well-nigh deserted and much of the Mormon property had been confiscated and the prophet had been slain. The place has stagnated ever since. In the height of its prosperity and power it had nearly thirty thousand inhabitants. Now there are twelve hundred. The situation is very attractive, with the river making a long sweep around a peninsula two miles broad. The land is all high enough to be beyond the reach of the floods, and recedes from the stream in a smooth stretch of meadows and fields to where, at the neck of the peninsula, there is a sudden rise to a commanding plateau. At the crest of the rise stood the great Mormon temple; but the business centre was down below on a broad street running across the peninsula and ending with the river both north and south. This wide avenue is still as it was, and so are many of the parallel streets and crossways. You can easily trace the orderly plan of the city- the skeleton of the vanished metropolis - though the old thoroughfares are nearly all grass-grown, and not 
IS6 Highways and Byways ot the Mississippi Valley intrequently there is scarcely a sign of travel on them.

Some of the Mormon dwellings were of brick, some were frame structures. and many were of logs or of wattle daubed with slay. A considerable number of the brick and frame buildings have survived and are scattered about the old citr centre and far back into the countr: On the high river bank at the south end of Main Street is the home of the prophet Toseph Smith - a claphoarded. unpained tarmhouse of moderate size. It neter was rery substantial, and though it is still ocupied. the passing years have lett it badly dilapidated. One of the chambers was pointed out to me with the intormation that the prophet used to get his revelations from God " in that there room."

In the rard on the shoe that tonts the river lay buried the prophet's wite Emma. and ro:ndabout were several other graves. some marked by headstones. but more whth only a hew rocks piled up on them. or roughly oulined with a row ot briks. The ground was rather disherelled: tor the spo had served some prerions inmates ot the house as a roosing-glate for their hogs. Jow it was orergrown with weeds and straggling

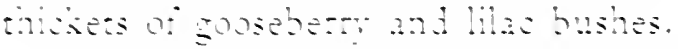

Aross the way trom the prophets hoves is a latge wo-sory building whith he ran as a hatel. In one ot the unper rooms is a seoret doset. It is a sloset whthin a closer and rem well concenled. A townsman 



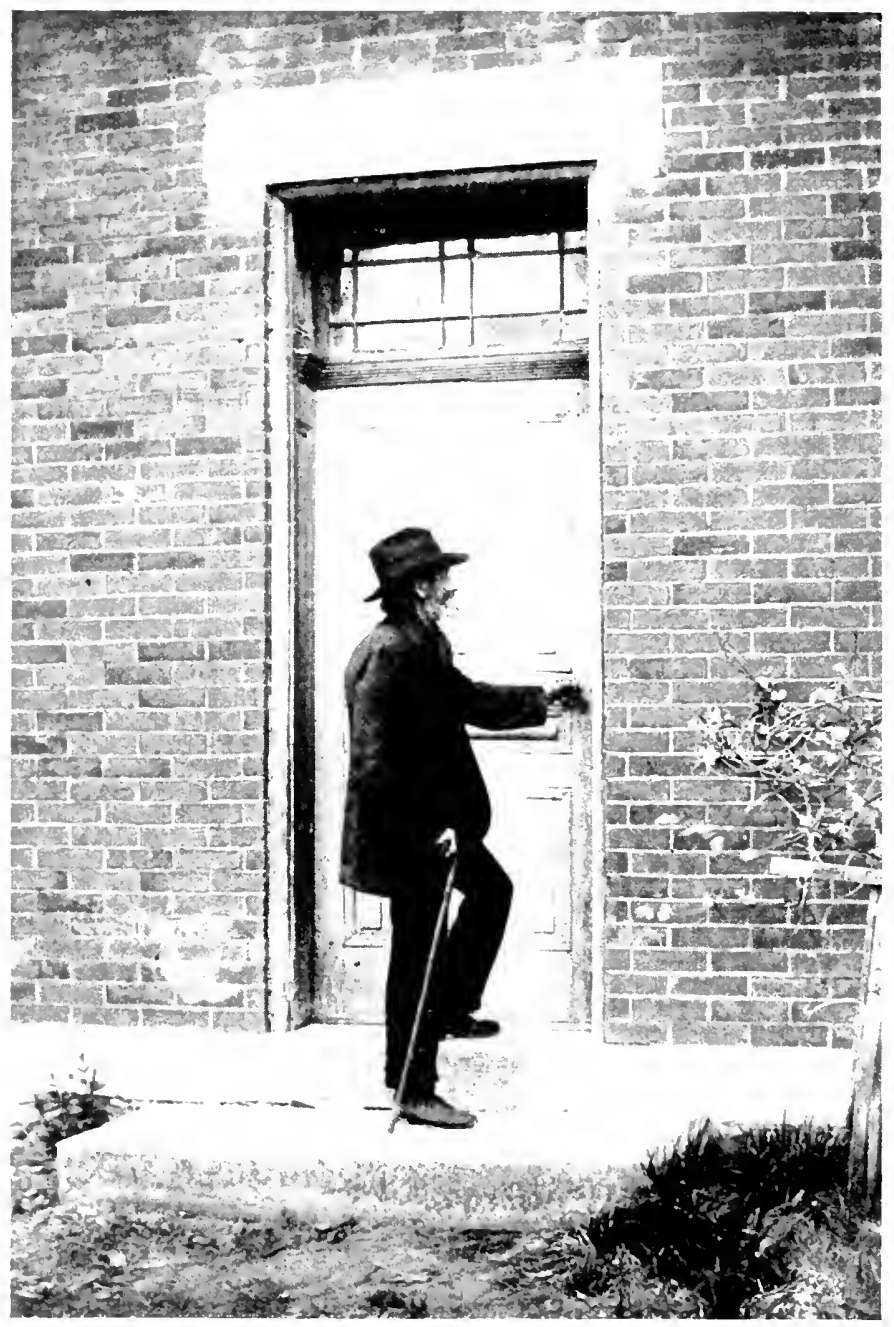

Ax (O,D Mornox DOORWA 
in speaking to me of it said: "No genuine prophet of God would have had such a closet. It shows he had a guilty conscience."

Another person told me that Brigham Young was killed in the secret closet, and added, "They say spatters of his blood are to be seen on the wall yet, and some people who go in there imagine they see his ghost."

Every dweller in Nauvoo had something to tell about the Mormons - opinions, facts, legends, hearsay. Their occupancy of the place and the tragic events connected with their leaving overshadow all other happenings before or since, and the interest is always kept fresh by the questionings of chance sojourners, and by the many Mormon pilgrims who come from Utah to visit this ancient stronghold of their faith. The old hotel is now the abode of a washerwoman, and I found her much concerned over some Mormon missionaries who had recently preached in the town. "They were fullblooded ones," she said - "four long-legged things, with coat tails down to their knees, and I didn't like the looks of 'em. They preached and sang up here on the park, and they boarded with a man who had a houseful of daughters. My goodness! I thought that was funny."

But there were other things she talked about that were of more personal importance to her. "A year ago I got the malaria from picking strawberries," said she, "and it laid me flat on my back. I never got better 
188 Highways and Byways of the Mississippi Valley

from June to October, and it's only lately I stopped havin' stomach chills so't I could work as I used to. I'd like to see a man work the way I've worked; but the men around here won't take a job unless it jus' suits 'em. They rather be idle, and they wouldn't lift a hand if their wives was to drop dead over the washtub. I go at it before six in the morning. When noon comes I stop to cook a bite to eat for myself and the chillens; but I'm soon to work again, and many times I've washed and ironed and had a dollar earned by three o'clock."

Farther back from the river is the house of Brigham Young, a substantial building of brick. This and all the other brick structures of the Mormon régime never failed to have a touch of quaintness. They showed their age, and many had broken windows and cracked walls, and a few were deserted and hastening to ruin. Some of the old-time brick buildings are gone altogether, and the only reminders of them are remnants of foundations turned up by the plough and hoe in the fields and gardens. The business portion of Nauvoo is now on the hill; but except for a little cluster of stores the place is a rustic village. Great quantities of fruit are raised, especially strawberries and grapes. The latter are very largely made into wine, and there was always wine on my hotel table. Indeed, the landlord declared it was against the rules of the house for any guest to drink water. 
The cultivated fields were models of neatness, which may be because the owners are mostly Germans. The Germans are thrifty and are reputed to have plenty of money; but the citizens of a more nervous nationality are wont to affirm that they have no enterprise and do not care whether the town booms or not.

Nauvoo is seriously handicapped by the lack of a railroad. It is true the railroad is within sight on the west bank of the Mississippi, and a steam ferryboat plies back and forth across the broad stream, making five trips a day; but when the river freezes the only substitute is a rowboat shod with runners. This can go after a fashion quite independent of what element is beneath it. If there are spaces of open water or ice too thin to bear the boat's weight, the crew use oars and poles; but where the ice is thick they get out and haul and push. No matter how bad the conditions, it at least contrives to make one trip daily.

The placidity of the Germans was an irritation to some of their more strenuous neighbors; yet it was quite delightful in its way. One of them with whom I made friends was a fat elderly man whose pudgy features and blue eyes were always twinkling with a smile. He was a picture of care-free happiness and contentment. When I asked him whether he was going to get a task he had started done that day, he said he did not know. "I works till I am tired and then I stops," he explained. 
I90 Highways and Byways of the Mississippi Valley

He had an osage hedge about his vineyard, and its thorny tangle was something of a trouble to trim and keep in order. "But dere is a school near," said he, "and dot is de best fence dere is for dose poys. Der hedge have so many stickers dey think twice before dey try to get through dot."

As to the Mormons he said they used to go out into the country around and "steal sheep, pigs, everything; and dey had to do dot dere vas so many to feed. Mine gracious! some of dose men had one hundred and twenty-five childrens."

Opinions of the character of the old-time Mormons varied. Many wild deeds were done in their day; but not all the ill-doing could be justly laid to them. One early settler who had the air of wanting to be aggressively fair to friend or foe said: "I remember when they were here very well, and the majority was all right. They were industrious and prosperous, and a happier people didn't live on top of God's earth. Naturally, a new town that had grown in five years from nothing to twenty-eight thousand would draw all sorts of folks to it, and would be more or less tough. Lots of fellows come here busted. They'd got to make a livin' somehow, and they banded together and stole instead of workin'. If one of 'em got arrested the others would swear the son of a gun was somewhere else all the time it was claimed he was breakin' the law. So he'd get off. "I've heard said that the Mormons would go a few 



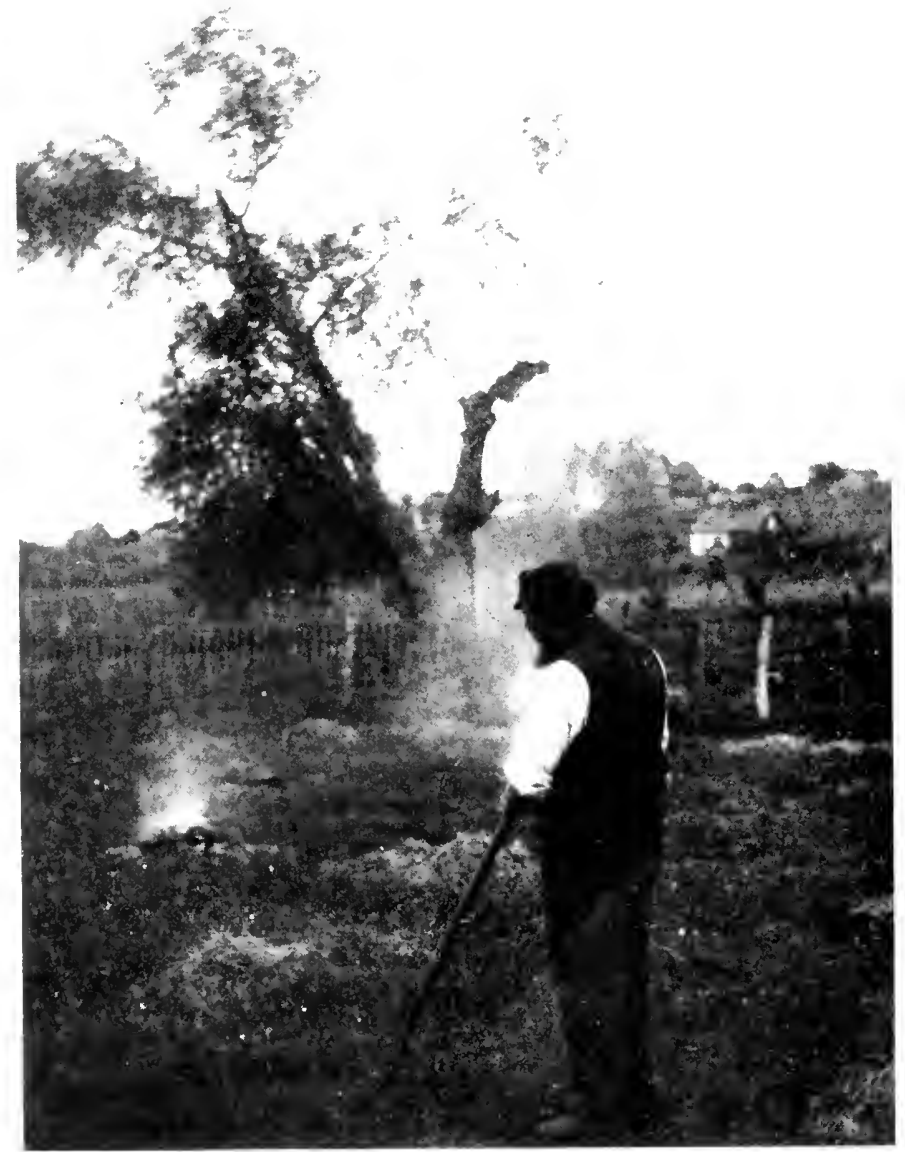

A Garden Bonftre 
miles out back here in the night and kill a cow in some man's pasture and get the carcass in their wagon and let the blood drip along, and that then the other cattle would foller the trail of blood and the Mormons would get the whole herd. I've been told, too, that a great many cut-throats and thieves joined the Mormons, and that the church kind o' protected 'em when they got into trouble. Well, such things are easier charged than proved. You see there was a good deal of excitement and suspicion about the new religion and the way Joe Smith and the rest was carrying on; so pretty much all the crimes that was committed and some that wa'n't committed at all was laid to the Saints. I wish the lyin' hounds who invented those stories could 'a' been punished as they deserved.

"I reckon the farmers would often break the law on the Mormons' credit. There were men so anxious to get the Mormons into trouble that they would steal and hide things on the Mormons' premises and then get out a search-warrant to convict 'em of the crime. Perhaps all that would have blown over if the Saints hadn't got to quarrellin' among themselves about this here spiritual wife business. Those who contrived the idea claimed it wa'n't polygamy, and that the extra wives who was sealed to a man - whatever that meant was to be his, not in this world, but in the next. Pah! That was their way of pulling the wool over people's eyes. 
192 Highways and Byways of the Mississippi Valley

"The kickers started a paper here they called the Expositor, and they banded in with all those who wa'n't Mormons and wrote like the devil against the new religion. 'Drive the Mormons out of the country,' was what the Expositor advocated. The Saints got mad, and the city council passed an ordinance against the apostates' paper, and the city marshal went to the office with a blacksmith, who pounded the press to pieces, and they threw the whole concern out into the street. That was the 7 th of June, I844, and twenty days later Joe Smith and his brother Hyrum was corpses. We had wild times for a while, and the outcome was that the Mormons thought they better skip from this region.

"There was apostates, as I said; but most of the Mormons stuck to their religion through all their troubles and the discussions. They were just like other people - very tenacious of belief. Joe Smith was like other people, too. Most men would like to be pope if they could, and Joe enjoyed the power his scheme brought him. Some think it's strange he could get so many to accept his religion; but people can be worked up to believe anything. It's easy to pick flaws in his theology, and it's easy to pick flaws even in Christianity. Now I tell our good Christians they ought to make a saint of Judas. If he hadn't brought about the death of Christ none of us could be saved, could we? Ain't that logic? There's a good many 
things in the Bible don't seem quite right to me. For instance, I haven't never liked that saying, 'Unto everyone that hath shall be given.' If I'd been writing it I'd have said, 'Him that hath little, give him a little more. Help him along.' But what's the use of talkin'? There's good men in all denominations, and there's just as good outside of any denomination."

The turmoil that brought about the migration of the Mormons from Illinois was a curious mixup of persecution, politics, religion, and warfare. The Mormon votes were a valuable asset; for neither of the two leading political parties in the state was strongly ascendant, and concessions were made to the Saints that could not have been obtained otherwise. But at length feeling ran so high and the situation became so threatening that troops were sent to keep the peace. The Mormons had a trained body of militia of their own, known as "The Nauvoo Legion," and this prepared for resistance. Pickets were posted, and when the state troops approached there was a real battle on a small scale. A man who lived at the time on the town outskirts where the sharpest fighting occurred told me something of his experiences.

"The bullets was flying thick," he said, "and my father set up a lot of plank along the northeast corner of our house to kind o' protect it, and he sent me and the rest of the family down cellar. We stayed there three or four hours, except that I crept upstairs once in a 
I94 Highways and Byways of the Mississippi Valley

while to see what was goin' on. Both sides had cannon, and when the cannon belonging to the assaulters was shot off, the Mormons would chase the balls and shoot 'em back. Two Mormons was killed, and the prophet and his brother Hyrum was carried off and put in the county jail at Carthage.

"In a few days it was talked around that the governor intended to set the prisoners free. But the people had got tired of the Mormons' doin's and was bound to break 'em up. So a band of about two hundred men fixed like Indians, with their faces painted red, black, and yellow, went to the jail and called Joseph and $\mathrm{Hy}$ rum Smith to the window. Soon as the two brothers looked out dog-gone if the mob didn't shoot 'em dead, and the body of the prophet fell out of the window on to the ground.

"Most of the Mormons moved away in the next few months and the last of them skedaddled in $1 \delta_{+7}$. That left a big city of buildings and only a handful of people, and the Mormons got little or nothing for their property. The flat down here was all built over, houses behind houses about as thick as they could stand. A good share of 'em was of logs and dry to the core, and when a man bought a place down there he'd pick out the best house on it to live in and use pretty near all the rest of the buildings for firewood. So the city disappeared, and it wa'n't long before some man whose wife had been coaxed off by the Mormons burned the big temple out 


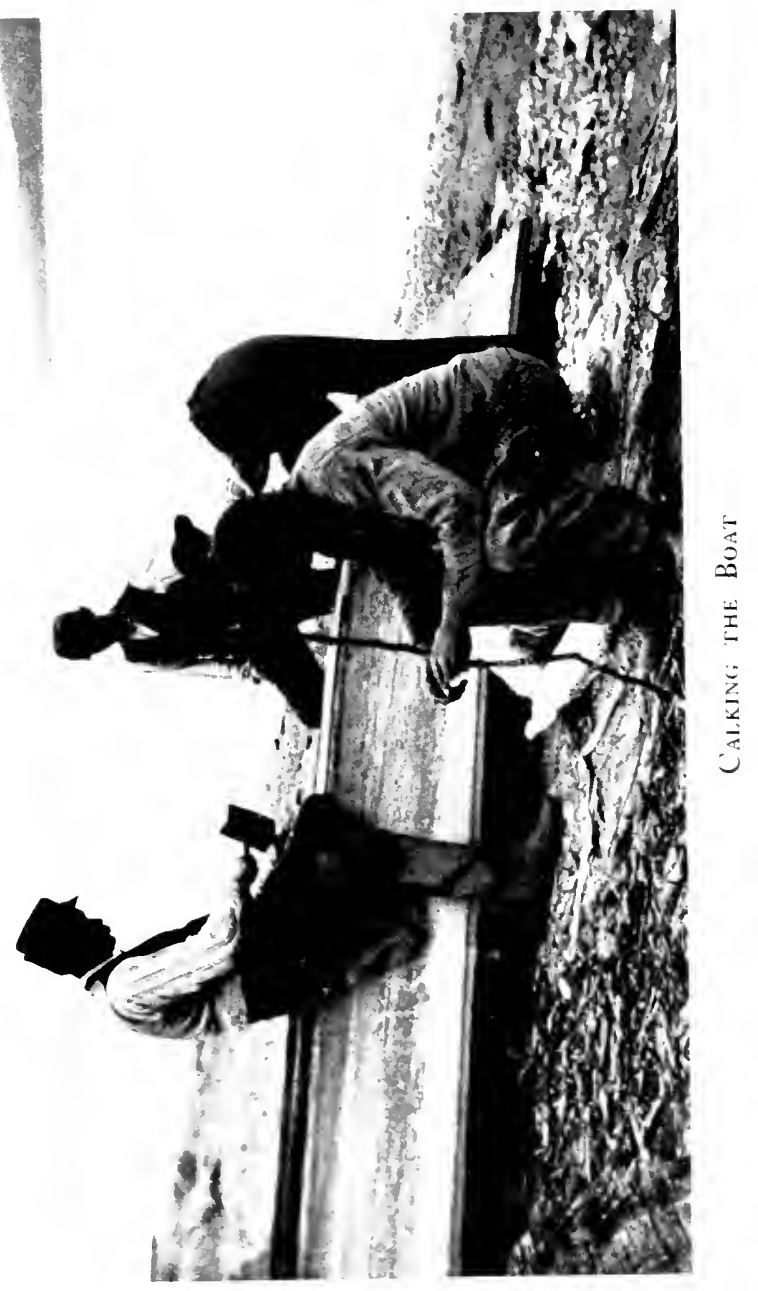


. 
of revenge. He never was punished for it, and no one knew rightly who done it until he confessed on his death-bed."

Another queer phase of the town's history began, soon after the Mormons departed, in the form of an attempt to establish a Utopia at Nauvoo. A member of this Utopian community told me its history. "We called ourselves Icarians," said he, "and the plan was to work one for all and all for one. As the words of our golden rule put it, 'From each according to his powers; to each according to his needs.' It was a beautiful idea; but you know the story of Icarus. He made himself wings and fastened them on with wax. They carried him wherever he wished to go, until one time he flew too near the sun and the wax melted. Then down he come, and we done the same thing. Our leader was Étienne Cabet, a great French lawyer, writer, and politician. He was well educated and had most rosy prospects; but he wanted to reform the world and he sacrificed everything for that. He begun with writing a novel called, 'A Voyage in Icarie,' describing an ideal nation. The book was a great success, and the people in France were enthusiastic over it - yes, crazy over it - and they wanted to see such an attractive state of things as was pictured in the novel realized.

"So Cabet began organizing, and soon no less than four hundred thousand persons had signed themselves his followers. Then he made the proposal to build up 
I96 Highways and Byways of the Mississippi Valley

an actual Icaria in America, and the idea swept France like wildfire. Shortly, he had secured land in Texas, and sixty-nine men of his Paris disciples volunteered to go there. They left their families and voyaged to the new country. The land Cabet had bought they supposed was easily accessible; but it proved to be unbroken prairie, which they only reached after a terrible overland march of two hundred and fifty miles. They were loaded down with absurd and useless baggage, not one of them could speak English, and they were artisans or professional men who knew nothing of farming and pioneer life. They stayed through the summer, but eighteen died of malaria and the rest were so disheartened that they started back for France.

"They got as far as the Red River and there met a new lot of recruits, and the whole party went to New Orleans and spent the winter. A committee was sent up the Mississippi to seek a more favorable locality than the one abandoned in Texas. This committee reported enthusiastically on Nauvoo, and in March, I $8_{49}$, Cabet himself with three hundred men, women, and children came here and established homes. We fixed over old buildings and put up new, and we had gardens and shops of various kinds, and after a while we built a distillery and manufactured whiskey. That was against our principles; but we needed the money. Every one had something to do, and yet no one was to over-exert himself. It was Cabet's idea to make labor pleasant, 


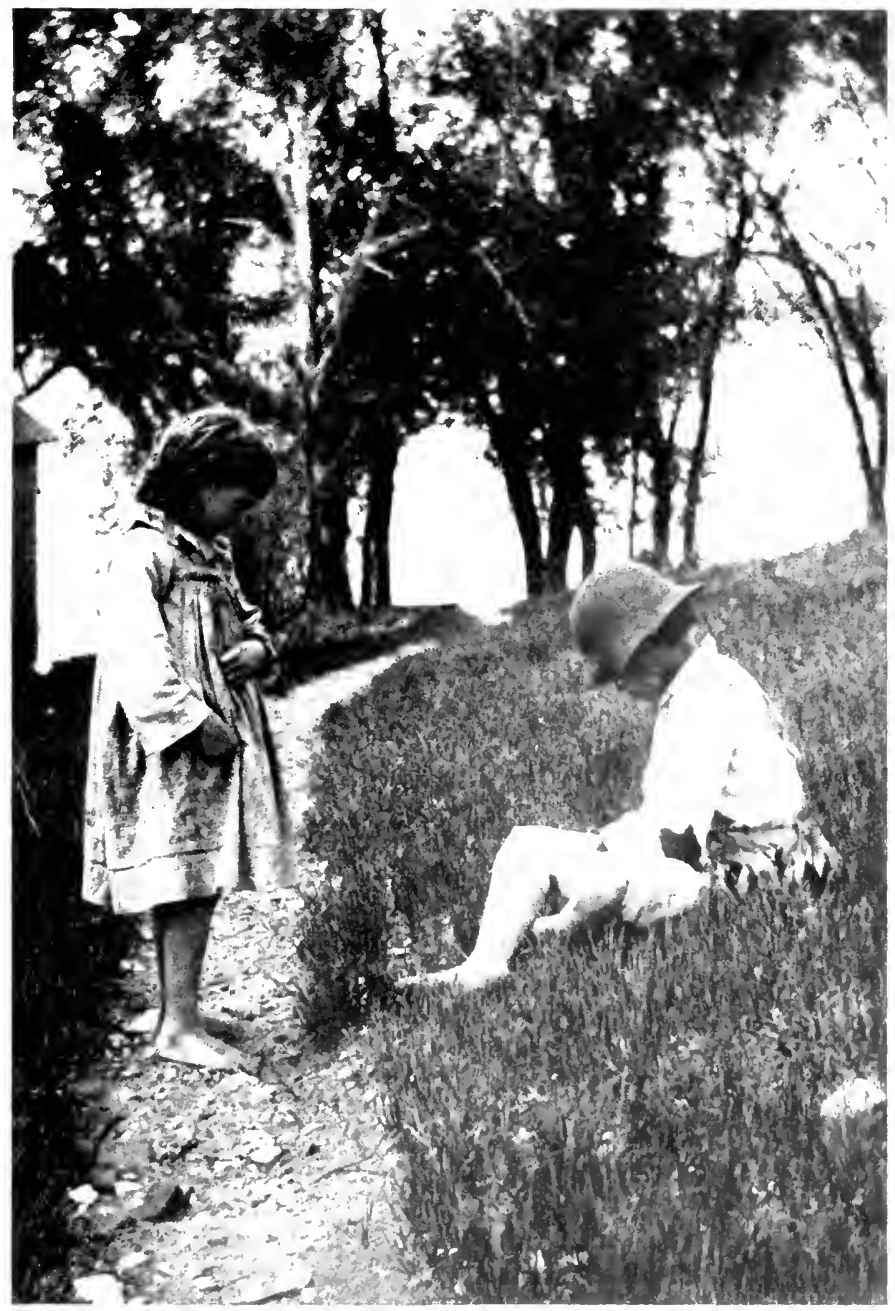

WakINo; a Whelow Mhate. 


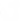


and he done it; but he didn't make us prosperous, and while a great many joined, a great many left, too. The largest number we had in the colony at one time was about six hundred. Some of those who joined had the sense to get out after being with us only a short time, and seeing the scheme was not practical. Often a woman would induce her husband to leave because we had to be very economical, and she'd been used to better things. Then, again, we had everything in common, and a man who was pretty smart and knew he could make money faster'n most of the others, didn't like to be pinned down to an equal share, and so he'd cut loose.

"Cabet thought we should be such a happy family and give the world such a beautiful example of working for each other that every one would flock to join. But he didn't know human nature; and though the newcomers brought money, and money was sent us by people in France, we was always hard up, and that sort of thing didn't attract the public to become Icarians. Cabet was a splendid talker, and it was delightful to listen to his Sunday lectures. He was admirable in many ways; still, there began to be a lot of disagreeing and criticising among his followers. He was a lawyer by trade, and he made so many laws an opposition sprung up that at last succeeded in outvoting him and putting in a new man as president. Then Cabet's partisans refused to work, and the new president re- 
I98 Highways and Byways of the Mississippi Valley

fused to feed them, and the colony broke up in a row. That was in 1856 . Cabet went down near St. Louis, and in December of that year he was found one morning frozen in his bed."

Thus both the Mormon and the Icarian colonies had a depressing experience in Nauvoo, and the tragic death of their leaders nearly coincided in each instance with the end of their followers' occupancy. However, when the Mormons abandoned the place their ranks were not broken, and they started on a long pilgrimage across the wilderness to Utah.

"Yes," said one of the local dwellers to me, "the Mormons was obliged to skin out from here, and if you want to know how they went you call on Granny Howard. She lives with her son - and he has a loom in the house and weaves rag carpets. She's over ninety years old; but she does her own work, and in her spare time she sets and sews carpet rags, and she don't wear any glasses either."

I found Granny Howard just as described "At the time the Mormons left here," said she, "we was livin' in Iowy on a main road leadin' westward. Some of the Mormons' wagons was drawn by mules, some by oxen, some by cows, and the poorest people pushed along little carts by hand. They went past thataway for weeks the whole summer through and into col' weather. My heart ached for 'em. But they was a jolly set, I tell you. They was jis' as cheery as if nothin' hadn't 
happened. I went to one of their Sunday meetin's by the roadside, and oh, sich pretty singin' I never heard in my life! I remember one ole woman stopped at our house an' asked my mother if she wa'n't afraid of 'em. “" Bless your ole soul,' my mother says, 'I ain't done you folks no harm, and I reckon you won't do me any.' " 'No,' the ole woman says, 'we won't harm a hair of your head;' and they didn't. We never lost so much as a straw."

The grayhaired son had stopped the clatter of his loom in the next room and now stood in the doorway. "I was in the Civil War," said he, "and I've been all aroun,' and the Mormons was as nice people as I was ever among. That there temple they had here was a fine thing, and I believe, by golly, they'll come back to Nauvoo some day."

He, like many others of the citizens, was an admirer of the local attractions of the town - its fertile lands and its overlook on the long loop of the river; and they are all quite certain no spot in the whole valley is so beautiful or better suited for the site of a great city. They are sorry the Mormons were driven out; for when they left, the place was larger than Chicago, and there was every prospect of its growing to be one of the biggest and most important towns in the nation.

As to the Mormons, they suffered much, and their prophet came to a melancholy end which at the time seemed a culminating disaster; and yet his death and 
the other Mormon fatalities proved to be a fortunate thing for the system he founded. The church now had its martyrs, and a halo of glory enshrined their memories. The methods of their assailants had been unreasonable and lawless. Nevertheless, the underlying cause of the persecution had a certain justice in it. The Mormon population was an unmanageable factor in political affairs. The vote was sure to be a unit, and the centralized power of the organization was a dangerous element in the state. Seemingly the mob struck at the Mormon's liberty of conscience, but really the chief thing hated and feared was his lack of liberty of action.

The effect of the persecution, however, was to make the Mormons tenfold more Morman than before. It only added to their fanatical enthusiasm. A man will think twice about inconveniencing himself for his religion, he will hesitate to make himself poor for it; but show him that another man stands ready to slay him for adhering to it, and he is instantly prepared to do battle, not so much for the religion as for his right to believe in it if he chooses.

Note. - Nauvoo has the charm of an historic and exciting past. It has a beautiful and impressive situation, much survives to remind one of the Mormon days, and few places in America are more moving to the imagination. It is a little off the beaten path of travel, but that is only a matter of being across the river from the railroad, which helps to keep it unchanged and preserves the charm. The tourist who fails to see it misses much. 


\section{XI}

FARM LIFE IN IOWA

T SUPPOSE if any state in the Union was to be picked out as preëminently a paradise of the farmer, that state would be Iowa. Nearly every acre of it can be cultivated, and repays generously the labor bestowed, the climate is kindly yet bracing, and access to markets is phenominally easy. "You can't find a place in the state," one man said to me, "that's beyond the hearin' of the railroad whistles. All our county-seats have at least one railroad runnin' through 'em, and most of 'em two or three. A man can work to advantage in Iowa anywhere. There's no more cheap lands to be had, and all the farm country in the state could be sold at an average of seventy-five dollars an acre."

My own observations bore out this man's claims. One seldom sees land that is rocky and thin-soiled, or any boggy hollows but that can be readily reclaimed. Nature smiles on the husbandman, and it is a pleasure simply to look on the great fields that sweep away in gentle undulation to the horizon. There are no absolute levels, neither are there any abrupt hills; but the 
202 Highways and Byways of the Mississippi Valley

landscape rises and falls like the big smooth swells of the ocean after a storm. From the top of the swells you are especially impressed with the marvellous extent of beautiful fertility about you. Even the skies seem more vast than you have ever known them in the East. Most of the land is cultivated, yet there is much pasturage where numerous cattle, horses, sheep, and hogs graze, and there are frequent streaks and patches of trees. Sheltered homes are scattered broadcast over the face of the earth, and thrift and plenty seem to be universal.

On my first day in Iowa I left the railroad and went for a ramble out into the farming country. The weather was mild and sunny, and the air so still I could hear ail the sounds for miles around - the whinny of horses, the barking of dogs, the clear call of the bobwhites, and the mellow sighing of the turtle-doves. The turf was sprinkled with dandelion gold, and the butterflies were flitting about enjoying the heat that shimmered over the fields. When I crossed a creek and stopped on the bridge to look down into the stream, I caught the gleam of silvery scales as the fish gambolled in the water; and now and then a fish would come up to the surface with a sudden flip that would start a circle of ripples.

Late in the afternoon I called at a farmhouse, and I made arrangements to stay as long as I lingered in the region. My hosts were Americans of the best type- 
intelligent and prosperous, yet living simply and working hard. It was a matter of pride to them that they owned a piano, for the neighbors had only organs.

But the thing in the house which gave them the most real satisfaction was a telephone. This connected them with nearly all the farm dwellers in the region and also with the town. The telephone line was a local enterprise, and the cost of maintenance was only two or three dollars a year. They used it constantly both for business and for pleasure. It saved time and money and it did away largely with the isolation which before had been characteristic of farm life; for homes were rarely close enough to each other so that families could fraternize freely, even if those who lived next each other were particularly friendly. The telephone was the more important to my hosts because they were not on the main highway, and their road was enlivened by few passers. They always looked out when any one did go by and made a guess at the person's probable business, and if they did not happen to know the person would remark, "Well, who in creation is that?"

Besides annihilating distance so that the members of each family could visit with whom they pleased, it enabled them to listen when others visited. The rules did not countenance this, however, as the daughter of the house at my lodging-place said, "'Tisn't often any one finds fault about your listening, because they do it theirselves, too." 
204 Highways and Byways of the Mississippi Valley

So if she was not especially busy when the telephone bell rang up a neighbor, she took off the receiver and held it to her ear a longer or a shorter time, according as the conversation proved entertaining or otherwise.

The surroundings of the house did not show much thought for appearances, and the shaggy lawn and few shrubs and trees got little care. At the back of the house were the barns, corncribs, and other buildings, quite a collection in all and scattered over considerable ground. Near the barns were a miry hog enclosure, a cow yard, and a calf pasture. The cattle were allowed to run free the winter through; yet they have a shed closed in on the windward side for their protection and are fed regularly with hay and with corn on the cob. The hay is stacked outdoors, except what is needed for the horses; and from the stack a load is taken daily in cold weather to a rack in the pasture for the cattle. A windmill pump keeps the farmyard supplied with water. Every farm has to have its windmill, and you see the slender iron frameworks sticking up all over the country.

The farms vary a good deal in size. Some have only forty acres, others eighty; but one hundred and sixty is the usual size. Many of the farmers have, however, added to their original holdings and own three or four hundred acres, and there are occasional men whose possessions run up above a thousand. In fact, farms are fewer than twenty years ago, and you find frequent 



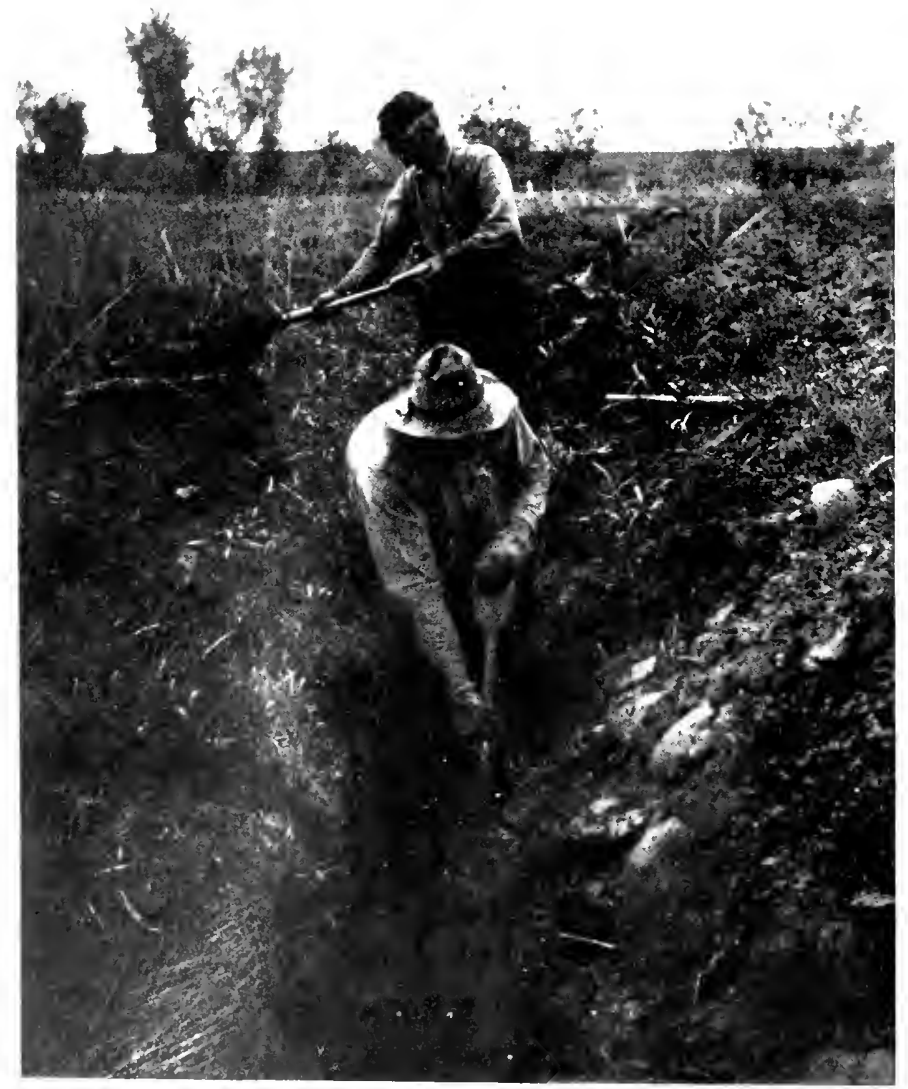

DIтенам, 
deserted houses. The empty dwellings and outbuildings are nearly always ruinous. They were probably not very substantial in the first place, and lack of care and leaky roofs and rough winds soon bring them to earth. But the protecting rows of trees that grew near may remain long afterward and mark the old home site that otherwise has been absorbed into some big pasture or cultivated field.

Quite a percentage of the farms are rented. The owners have acquired a competence, and on account of age or lack of health have moved to town. They receive a rental of from three to five dollars an acre; but out of the receipts they pay taxes and also attend to repairs on the buildings and fences. The returns are therefore not very great on the amount of capital the farm represents; but the owners prefer this land investment to putting the money into a savings bank, because they have greater confidence in its safety.

"Most of the people who have been here any length of time own their places," I was told; "but there's a few wouldn't be content without a mortgage. A feller makin' a fresh start to buy a place has hard pulling. It takes a good deal of money for stock and machinery, and with land so much higher than it used to be it ain't easy payin'. Then, it seem like these here young folks now ain't as economical as the people used to be. Soon as a young feller gets a little money nowadays he buys 
206 Highways and Byways of the Mississippi Valley

a smart buggy and a horse. He wants to show off and so he don't get ahead."

The farm country is divided with interminable miles of wirefencing into lots mostly of forty-acresize. The people work the land in fields of that extent as a rule, and each field is devoted to one staple. They have no fancy for hand labor, use machinery almost exclusively, and skip a good deal of detail that we in the older states fancy is essential. Thus, in haying, if the grass is thoroughly ripe it is mowed in the morning, and in the afternoon is raked up and stacked. If green, it is allowed to lie until the next day. But in neither case is the grass teddered or touched after mowing until it is raked up.

Very little hoeing is done; but the corn gets considerable cultivating with a two-horse machine, on which a man rides day after day back and forth on the long rows. If the hoe is employed at all it is where the wild morning glories have grown so thick as to threaten to choke the life out of the corn with their entwining stems. The morning glories are the worst weed pest with which the farmers have to contend.

A troublesome pest of another sort is the gopher. This little rodent is always burrowing in the grass fields and making its endless series of dirt heaps. It throws up about a peck of pulverized earth in each heap from its underground tunnel, but seldom shows itself. The roots of the clover and the morning glories are its favorite foods. It is also fond of potatoes, and 



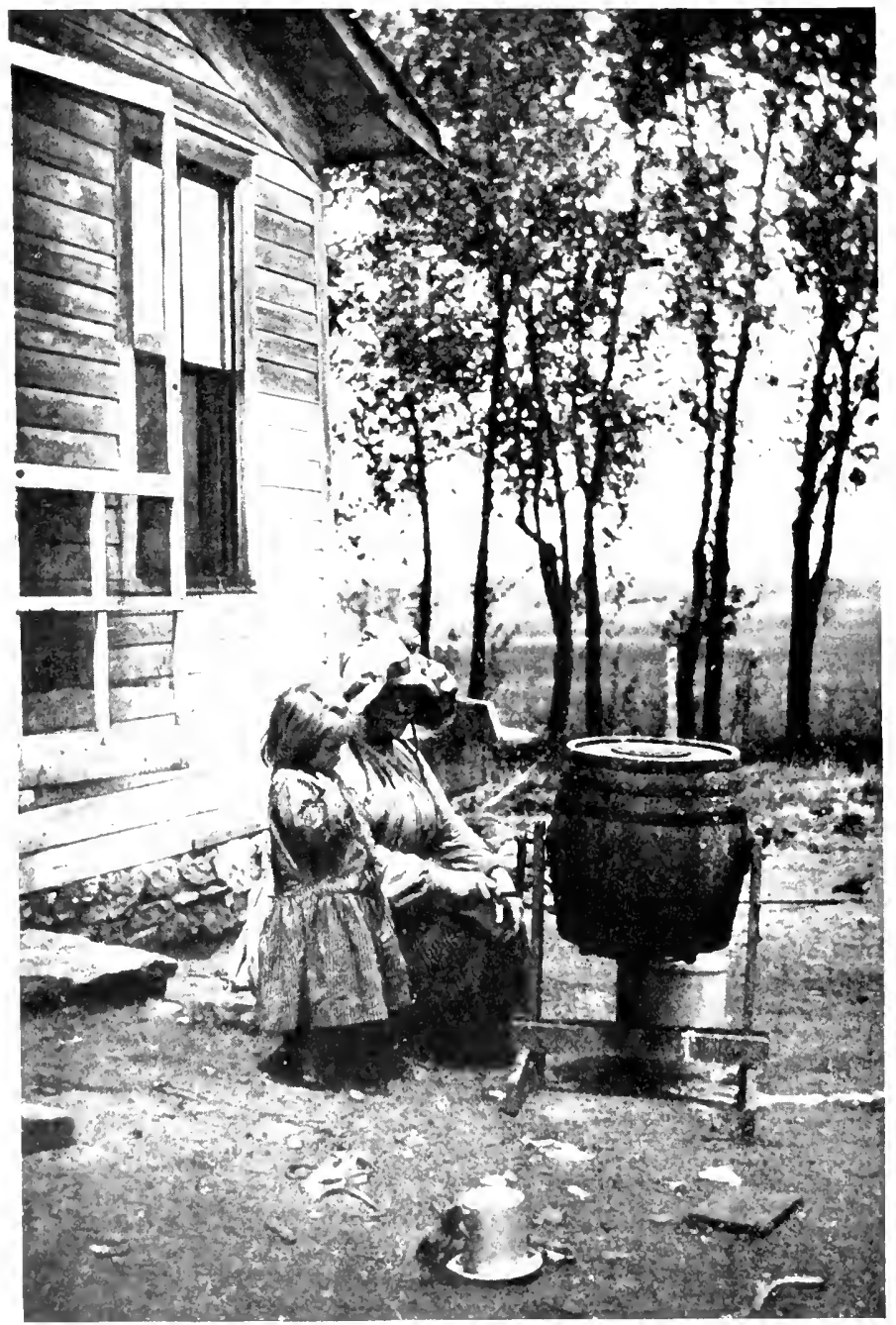

('HIR\IV: H IHE BWK DorR 
when a man makes warfare on it he digs down and drops a poisoned potato in the creature's burrows. The gopher's mounds are a great nuisance in the grass fields; for they clog the mowing-machine knife and often bring the machine to a full stop.

The majority of the farmers own a self-binding harvester, which they use in cutting their oats. Forty acres will make about sixty wagon loads or ten stacks. These stacks are arranged in two settings, each group of five stacks forming a square with one side of it gone so that the threshing machine can be placed in the middle. Sometime in August or September the threshing machine comes with three or four men to attend it and a dozen or fifteen of the neighbors to handle the bundles of oats, the straw, and the grain. The work is done in a day; but it is a day of high pressure. There is strenuousness indoors as well as out, for dinner and supper have to be provided for all the hungry crowd, and the thresher crew has to be kept over night. It is the most tumultuous day of the year; but its spice of excitement lends it a certain attraction, and the work is not nearly so irksome to the men engaged as is the more solitary and sober task of corn-husking that comes later.

Most of the corn is husked in the field from the standing stalks into wagons, and the labor continues in the chilly late autumn, for a month or more. Often the last load is not in until about Thanksgiving 
208 Highways and Byways of the Mississippi Valley

time. The weather and the coarse, sharp-edged husks are irritating to the hands, and the workers are usually obliged to wear mittens.

The farm people get up during the busy season at about five. The field tasks are done by six o'clock in the afternoon, and supper is served; but afterward there are the milking and other odd jobs at the barn and sheds which keep the workers engaged until about bedtime. In the winter they take life easier; are not up much before seven, and indeed only care to be stirring early enough to get the children ready to go to school. There is wood to cut, oats to haul to market, and the stock to care for; but work does not crowd, and some men will frequently drive into town with no object whatever, and simply "hang around."

Once in a while a "sale" lends spice to the farm life. "'The sale may be the result of a man's gettin' in debt bad," I was informed, "and he has to auction off his belongings pretty close to straighten up; but usually it's where some one is moving away, or a family is broken up by a death. They have the sales usually in winter, because other times of the year lots of us would be too busy to go. There's bound to be a crowd if the weather is good. The thing is advertised a week or two beforehand by posters, and people will come to it from a distance of eight or ten miles. I've seen more than five hundred men at a single sale. It's an all-day affair, and at noon the folks that are 


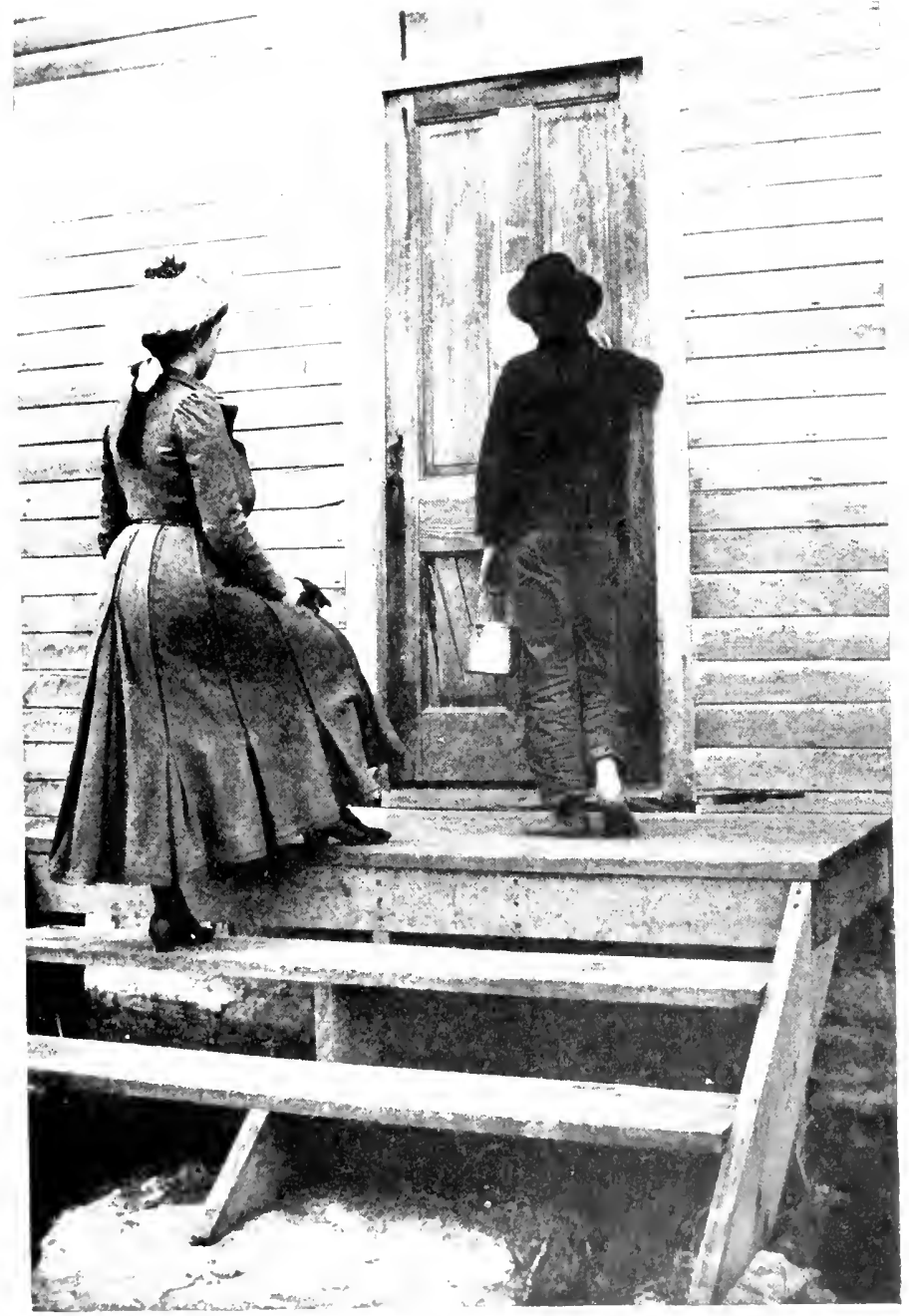

A Notice on the Schoulhouse Dook 
selling out furnish every one with a free lunch of bologny, crackers, coffee, and cheese."

There are seldom any drones in the farm families, and I observed that the housewives by no means confined themselves to indoor duties. One day I stepped into a yard where a sunbonneted woman was sitting on her back doorstep turning the crank of a barrel churn. At my approach operations were brought to a stop, and a young woman came to the door, and both she and the churner looked at me to see what I had to say for myself. I asked about the churn, and the woman explained it to me and told what good butter she made, and then said with a motion of her thumb toward the girl in the doorway, "Her and I do the milking. I don't like to eat the butter when the men milk. They have enough work without that; and you know they are around the horses so much they can't keep very clean, and they chew tobacco, and I can't help thinkin' they might be spittin' and get their tobacco juice in the milk."

A good many women in the vicinity milked, and they very often helped in the fields during the busy days of haying and harvest. Woman frequently drive the binders, put the oats in shocks, and some of them do considerable husking.

On one of my rambles I stopped at the local schoolhouse, a little white building prettily situated on a knoll with lofty oak and elm woods close behind it. 
2 IO Highways and Byways of the Mississippi Valley

A grassy forest road led away into the grove and furnished a short cut for the children who lived on the other side of the hill. Many initials were carved on the casing of the schoolhouse door, and among the rest of the decorations were the following lines which some one had laboriously written with a pencil:-

When a tode climes up a tree
pinch his tail and think of me,

to which was appended in a different handwriting the remark : or some other fool.

The room inside was rather attractive. It had curtains at the windows and a variety of pictures pinned on the walls. The children were orderly, attentive, and bright. As is usual, the teacher was without special training and merely a graduate of some village high school. Her methods were old-fashioned and the pupils recited rather stumblingly and parrot-like; but they were getting along fairly well, nevertheless. The boys come to school barefoot, and in overalls. That was their idea of comfort, and looks didn't count. They abandon shoes as early in the spring as they can induce their mothers to let them, and the shoes are seldom on the boys' feet again until the autumn days become decidedly frosty. The girls were dressed quite spick and span, and judging by their attire you would never suspect they came from the same families as the boys. 
Every winter there was an entertainment at the schoolhouse for the benefit of the school library. This was mostly prepared by the teacher and children, and was locally the chief social event of the season. But as a rule the people when they felt the need of relaxation had to resort to the town, where there was a chance to attend occasional lectures and concerts and now and then a travelling show.

The town itself was little more than a rustic village. I was there over Sunday. An unnatural quiet reigned from the earliest dawn, though the roosters crowed from coop to coop and the birds sang as usual. But by and by a church bell began jangling, and a few teams came jogging in from the country and hitched to the fence behind the Methodist meeting-house, and straggling church-goers emerged from the homes and went clacking along the board walks. I followed the rest. The service was of the usual sort, and I recall nothing special in its routine except that the minister had much to say of members who were in a "backslidden state" and played cards, danced, and went to the theatre, and that he also complained the attendance was not what it should be. "You farmers have got good comfortable buggies and carriages," he said, "and yet a little shower will keep you at home. Years ago when the people had nothing to come in but their heavy farm wagons they were all here every Sunday."

The farm folk were much more in evidence about 
2 I 2 Highways and Byways of the Mississippi Valley

the village on the day following. Their teams were coming and going in a desultory way from morn till night. Heavy wagons and covered buggies drawn by two horses were the rule. No one was in a hurry. The men had time to loiter in front of the stores, where they found convenient seats amid the displays of farm tools and new vehicles resplendent with gaudy paint. The women, too, were glad to meet and chat leisurely with friends. Often the whole family came to tradefather and mother and children of varying ages, from the toddler who stepped along with timid caution on the unfamiliar board walk, fearful that he might tumble off or get caught in the cracks, to the bashful youngsters a few years older, timid also from consciousness of being in the metropolis, but with eyes wide open to see all its wonders. Then there were the boys in their teens raw-looking fellows with misfit clothes and rough hands and tanned faces. Last, but not least, there were the little girls and the blooming maidens.

At length Mrs. Farmer finishes her shopping and hunts up her man. "I'm ready to go right now," he says, and they pack in their purchases under the seats and in between and all around until you wonder where the members of the family are going to bestow themselves. But they manage to squeeze in somehow, and off they go satisfied and happy, with the wagon springs sagging to the bumping point.

That evening an automobile came whizzing into town 


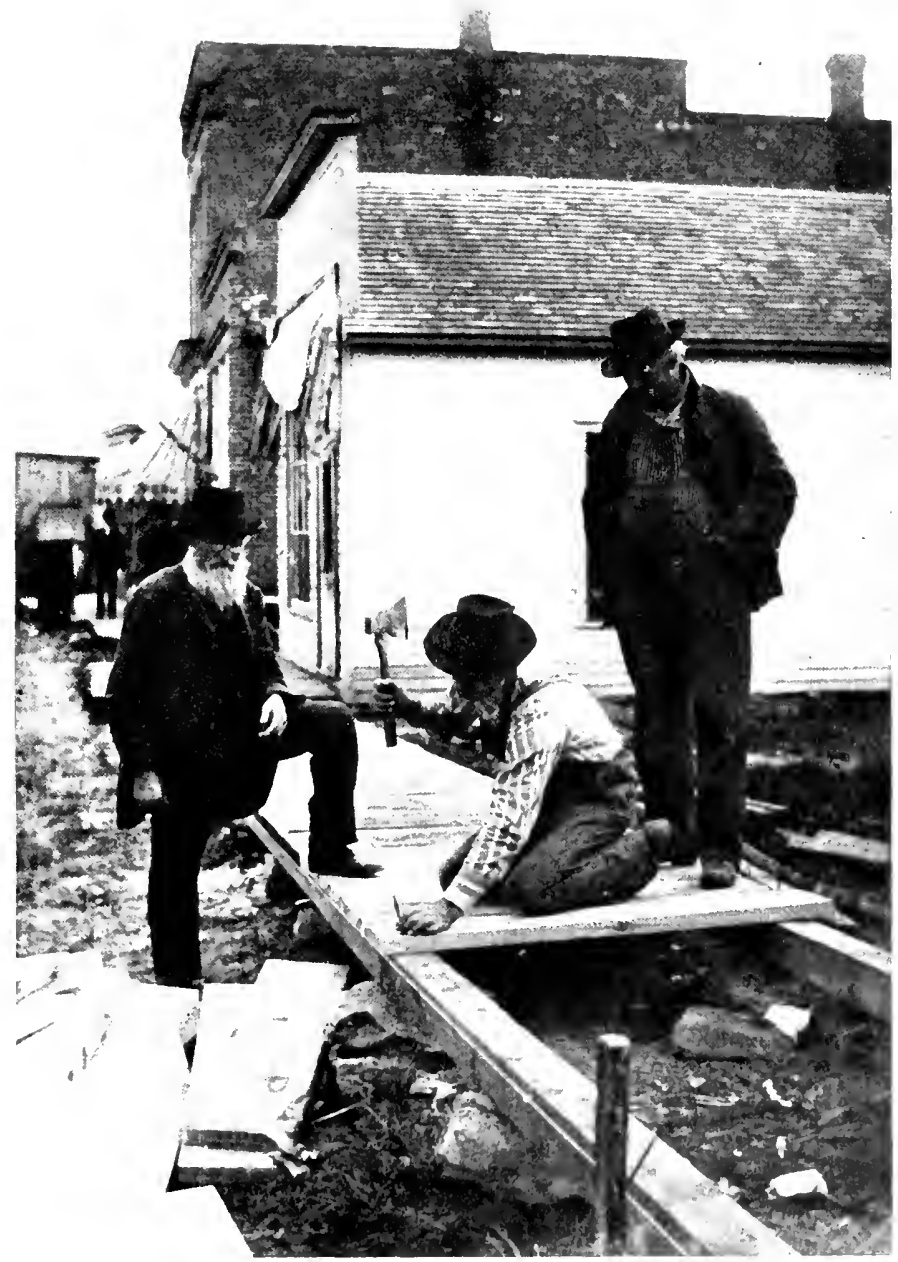

Renfwing; a Town $1 \mathrm{~V}_{\text {alk }}$ 

and stopped in the village centre. There were three young men in it. They stepped into one of the stores, and every one on the street gathered around the machine, and told each other what they thought about it. The three young men presently appeared, lit their cigars, turned up their coat collars, and prepared to resume their journey; but the machine refused to budge. They investigated and tried this method and that to coax it into motion; yet there it stuck. The crowd grew and was quite fascinated with the performance.

"I ain't never seen this auto out of whack before," said a man next to me.

"Where does it come from?" I asked.

"It belongs to two of these fellers," was the reply. "They live in the next town north and often pass through here; but they usually go just a-bilin' and don't stop."

"They stopped that time they scat Sarah Colton's horse," remarked another man who was listening.

"Why, yes, they did. You see her horse was hitched on the street here, and when the auto turned the corner the horse seemed to think Satan himself was comin', and it broke away and went off with heels a-flyin'. These fellers left their machine and give chase. The horse was too old to be much of a racer, and some one stopped it and the fellers brought it back and had the harness patched up, and settled with Sarah for the 
2 I 4 Highways and Byways of the Mississippi Valley damages, and went on. Their father used to have a clothing store, and he made money. Now they're spendin' what the old man saved. They won't get no more from him. The old man has made his windup, you know. He's under the sod."

But now the refractory machine had been induced to start and went whirling away in a cloud of dust, and the village resumed its normal quiet.

Note. - In Iowa beautiful farming country is almost universal, and if you would have a close acquaintance with it, stop off the train wherever you please and set out for a walk or drive. Any fair-sized town is very sure to have a good hotel, but accommodations among the farms is not always to be found. The better class of families are too prosperous and too busy to care to take in a traveller. So the safe and comfortable way is to get lodgings in some town and make short trips from there out into the region surrounding. 


\section{XII}

ON THE MINNESOTA PRAIRIES

TWAS at Dobbsdale, a country village in the southern part of the state. It was just after breakfast and I had sat down in the office of the town's one hotel with the intention of starting out for a ramble, presently. The room was rather dubiously odorous of more or less ancient tobacco fumes; but that is to be expected in the average hotel. The big stove was flanked on either side by a spittoon box - a shallow wooden affair with the bottom sprinkled with dirt, and the dirt sprinkled with burnt matches, cigar stubs, old quids, and other filth. The hotel was a clumsy two-story wooden building only separated from the street by a board walk. Several hitching posts bordered the walk and also a stout plank, which had been adjusted to serve for a seat when weather and inclination favored such use. There were board walks all through the village, though many pieces were shattered or missing. In the village centre was the usual straggling cluster of low stores, some of them brick, some wooden; but what was especially distinctive about the place was its abundance 
216 Highways and Byways of the Mississippi Valley of trees. Every street was lined with them, and there were many others in yards and along boundaries. They were well grown, and made the town a kind of human bird's nest, with an aspect charmingly peaceful and shadowy.

The region had been settled within the memory of persons still living, and Mr. Dobbs, the ancestor of the town, was not only alive, but hale and hearty and good for many years yet. He was the town's chief citizen, just as he had been from the first. It seemed odd that he should have called the place Dobbs's dale; for there was no dale, and the country about was almost as level as it possibly could be. But I suppose dale appealed to his fancy. He evidently had a touch of poetry in his nature, as it was due to his hobby that the hamlet was so well wooded. He began planting trees when he first came, and had never ceased planting them since.

"The way I happened to settle in this country," said he, "ware that my father fit in the War of 1812 , and he got a warrant from the government for a quarter section of land. So my brother and I come here in 1856 and brought a sawmill and got out timber and built us a house.

"Game ware very plentiful - thousands of prairie chickens and partridges and abundance of mink and deer. The streams ware full of pickerel, pike, and bass, and at first we just about lived on fish and what we shot. There was lots of beaver in the cricks, and the dams 
they made with their mud and moss was wonderful. I've seen popple trees a foot through they'd gnawed off. The popple ware the tree they seemed to like best; but they cut down willow and soft maple some too.

"There's game around here still; but it's been a good many years since I've had a first-class hunt. The last ware when a cousin of mine ware visitin' me. He 'n' his wife and me 'n' my wife hitched into a double express wagon and took our dinners and went after prairie chickens. It ware about the first of August. The young chickens are two-thirds grown then and are as nice eatin' as anythin' you could ask. We went out on the prairie, and then my cousin and I took our guns and commenced to walk. The ladies drove the team and follered us, and they'd keep track of where a covey lit. We had some good dogs, and we bagged a hundred and twenty chickens that day.

"When I settled here there was just one man in this region, and he had a cabin in the timber by the crick. But the emigrants ware arrivin' all the summer, and by winter we had a dozen families right around.

"Every spring and fall the Indians used to come here and stay a couple of weeks hunting and fishing. We never had no trouble with 'em until i 862. Then they made war, and for two hundred miles of the frontier they fell on the whites, and in thirty-six hours had killed nearly a thousand and took hundreds of prisoners. I don't know how the trouble began. Some say 
2 I 8 Highways and Byways of the Mississippi Valley

a party of Indians got drunk and murdered a man who refused to give 'em more whiskey, and that then they fled to their encampment, and the rest of the Indians decided to protect them. So they all went and started a massacree. Others say the Indians didn't get their rights from the government and ware neglected and ware paid their annuities in greenbacks instead of in gold or silver as had been the habit.

"Anyhow the Indians commencéd to burn houses and to kill as many whites as they could. The people flocked here from a hundred miles back, and when the first refugees come I can tell you things did look scarry. We got ready every gun and all the ammunition in the place, and posted pickets. Some expected the Indians ware right behind follerin' of 'em. However, they didn't show up that night, and we didn't really know what they ware doin' of. So the next day we sent out scouts. They found the Indians had gone, and they haven't disturbed us in our part of the state since."

These reminiscences were related to me by $\mathrm{Mr}$. Dobbs one afternoon while we sat in the shade of the trees on the plank bench in front of the hotel. The sun shone clear and hot on the dusty street. Three or four teams were hitched to posts and telegraph poles, and the horses stood half asleep patiently waiting for their masters. On the shadowed side of the street were a few men sitting on the stone steps or window ledges talking together or reading papers. On the sunny side 
the store curtains were pulled down to shut out the heat and glare. Business seemed to have come to a standstill, and in the depths of the leading grocery store I could hear the proprietor tooting on a cornet with amazing persistency.

None of the stores had signs, and I was informed that some stores had only been in business a few months and it was not time to expect them to get up signs; while the older ones were well known to everybody, and where was the need of their having signs?

On a corner across the way from the hotel was a oneman bank. When the village mail arrived the banker locked up while he leisurely visited the post-office. Next to the bank was what seemed to be a one-man store, and its proprietor, like the banker, went to the post-office; but he left his door wide open. He was a tall, round-shouldered man, with a leathery face and a brush of chin whiskers. His hat was a squatty derby of antique style, and his scant-lengthed trousers were patched on the seat. He was in his shirt sleeves and had his thumbs thrust into the armholes of his vest with an air of self-satisfied independence. In his window, amid a dubious array of merchandise, was a fly-specked card on which was stencilled the words

\section{GOODS SOLD AT COST}

I made inquiry about this sign and about his business. "He's an old-timer," I was told. "He was here before 
220 Highways and Byways of the Mississippi Valley

the flood, and he's been sellin' goods 'at cost' and makin' money ever since. He does most of his work himself, though he has a boy around to help when he can find him; but that's not often."

In the evening things grew busier, and now and then a buggy would arrive in a cloud of dust, and the street grew quite populous with teams and loitering people. Some trading was done, but more visiting. The men gathered in groups on the dim-lit walks before the stores and swore amiably at each other, as they chatted, by the hour together.

In what I saw of the region on my walks out into the surrounding country its aspect varied little. Whichever way I went I found smooth, straight dirt roads, and land flowing along endlessly with a hardly perceptible rise and fall. The staple crops raised in the great fields were corn, oats, and barley. Some wheat was grown; but the soil did not sustain it as well as formerly and it seldom does really well. Flax-growing, too, has been gradually abandoned for the same reason.

The farm dwellings were always among trees often in one of the natural oak woods, or on the edge of it; but more commonly in the midst of a planted square of poplars, willows, and maples that enclosed all the buildings and the garden. Every man apparently aspired to have a big red barn with a gambrel roof and a cupola on top. There were pretty sure to be flowers and shrubbery near the house; but in the remoter por- 


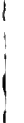




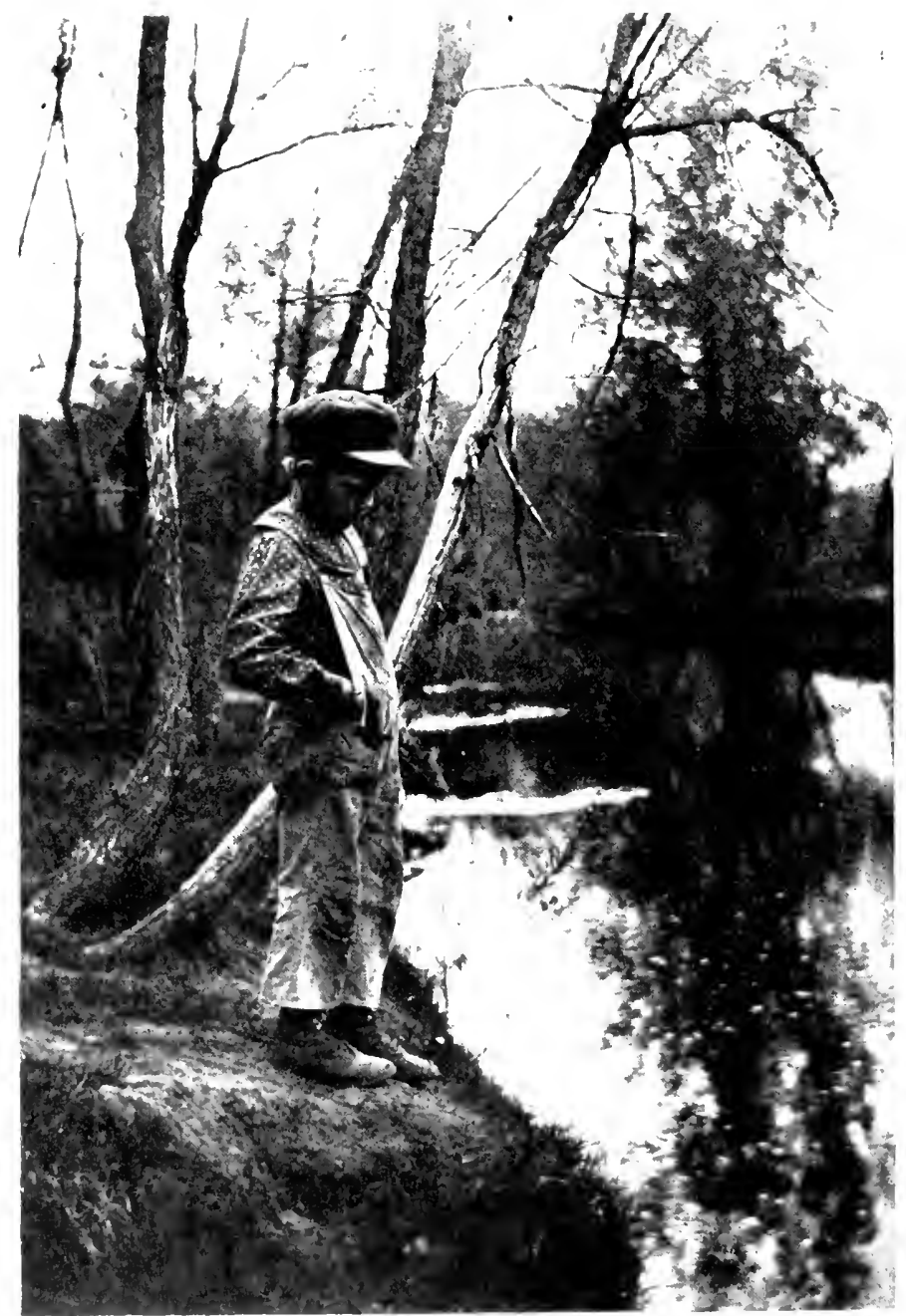

The Fascinaton of THE STREaM 
tions of the yard was much litter, including a woodpile, wagons, tools, worn-out machinery, and some more or less depleted straw stacks. The dwellings as a whole had a pleasing look of prosperity and comfort.

The tillers of the soil are of many nationalities, and they show a strong tendency to gather in racial settlements. Thus, in one vicinity you will find all Germans, in another all Norse, and so on. If settlers of a particular race are at all numerous in a district they have their own church and church school, and in the school the text-books are mostly in the native language, though enough English is imparted to enable the children to speak and read it intelligently.

I stopped at a German home one noon for dinner. We ate in the hot, smudgy little kitchen close to the stove. There were three children in the family, two of them boys, and the other a tall attractive girl, who waited on the table - probably because there was not room for her to sit with the rest. We had fried ham, bread and butter, coffee and cake. German was the ordinary language of the household, and before we began to eat, each of the boys asked a blessing in that language. Dinner for the youngsters consisted mostly of bread plentifully bespread with molasses. Every time a lad finished pouring from the molasses pitcher he gave the nose of it a swipe with his tongue to prevent its dripping. 
222 Highways and Byways of the Mississippi Valley

I asked the man if the Minnesota country suited him as well as his native Europe.

"Gosh, yes!" was the response; "but my woman complains about the cold long winter. It's a little bit too long. When I come twenty-seven years ago the land around here was owned by one man. He'd got a whole section, by golly, as a speculation. The land he sold me was covered with scrubby bushes and was so wet you couldn't walk anywhere without gettin' your boots or shoes filled with water. But cultivation and ditches has dried it off. About ten years ago I built this house and a new barn. I wa'n't goin' to live in an old shack all my life. I had to go in debt some, and that's the case with nearly all when they build; but most are gradually payin'."

After dinner we sat for a while in the parlor, which was impressively neat as the result of a recent housecleaning. The gay rag carpet had just been put back on the floor, and there was straw beneath it which made it puff up like a cushion; but it would tread down flat in time.

"Do you think the government'll continue this rural delivery that they been extendin' everywhere?" queried my host; and he also wanted to know if the cost of the service fell on the farmers. "Some people here say it ain't a good thing," he continued. "They claim the expense is more'n it's worth. I ain't talkin' much 
myself, because my son-in-law runs the mail car, and I don't want him to lose his job."

Views as to the farm prosperity of the region differed widely. I had a chat with one man planting corn in a wayside field whose comments were decidedly pessimistic. "I bought my land in this blamed country when land was cheap," he said; "and yet it's been mighty hard work to pay for it. I don't know as I could have paid if I hadn't had money come to me from elsewhere. You see when a feller borrowed fifteen years ago he had to pay ten per cent interest. Now you get lower interest, but the price of land is up to fifty dollars or more an acre. Whoever buys at such a price will never pay any of the principal in the world.

"It's them Germans up north of the town who have raised the price of land here. The thing happened this way - some German in Wisconsin sold out sixty acres he had there for one hundred dollars an acre. That made six thousand dollars, and he come here lookin' for another farm. Well, he struck a Yankee man up north of the town who had one hundred and twenty acres and wanted to sell. They got talkin' same as you and me are now, and the German offered all his money for that farm and got it. After sellin' at a hundred dollars an acre, fifty dollars an acre looked cheap, and yet the Yankee had offered me the same farm the week before for thirty-five hundred dollars. Since that sale no one will dispose of any land for less than that Wisconsin 


\section{Highways and Byways of the Mississippi Valley}

feller paid. He made a mistake, but them Germans are good thrifty people and get rich if any one can. They keep things lookin' nice around the house, too. The German women have all got a flower garden, every last one of 'em.

"The Norse are thrifty, too. Yes, they're about as careful a lot of citizens as we have; but I don't like 'em. They're a high-toned sort of people and honest; and yet at the same time they're selfish and have kind of a darn mean way. They don't have to be here long from Europe before they're a little ashamed of being Norse. Soon as they learn to talk English they think they're a little better'n you are, and act as if they had an idea they knew a blamed sight more than any one else. They're great hands to put up big buildings, and once in a while one attempts a little more style than he can carry out.

"That's the trouble with most people here. They feel bound to put on style, and so are kept in debt. They buy fancy buggies and two-seated covered rigs and other things of the sort; not because they need 'em, but because some rich men they know have got such things. They buy expensive machinery, too; but they don't take care of it. A man'll invest sixty or seventy dollars in a gang plough; and the first season he'll put it in the shed, but the next year he'll leave it in the field just where he got through using it. Some of the machines they run under a bunch of trees when 


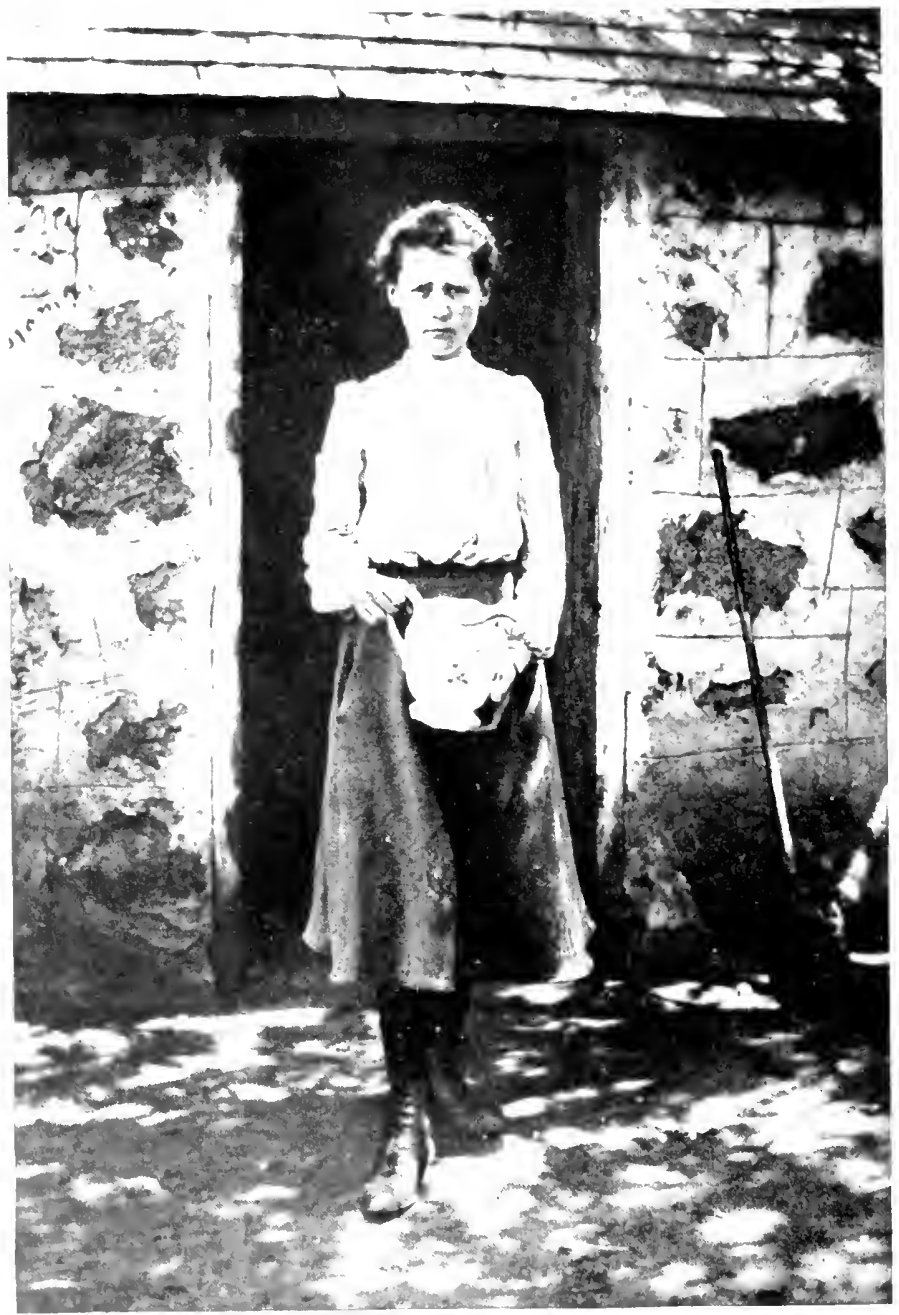

A PIICHFR OF MIIK 
they ain't in use, and there they stay and rot. The shade keeps 'em from dryin' after a rain, and they're ruined. They'd be better off right out in the sun. Worse still, the people keep a miserable lot of stock of all kinds - horses, cattle, and everything else; and they turn 'em out to pasture in the spring as soon as the grass starts, and the cattle keep ahead of the grass the season through and ain't never really well fed. The buildings, too, are put up just as cheap as possible and won't last."

The sky had been growing threatening while we talked, and I now thought it best to start for town. On the way I encountered a little spatter of rain; but it was soon over, the clouds drifted on and streaks of sunshine glimmered across the vast landscape. When I arrived at the hotel office I found several people there driven in by the shower and in no hurry to depart as long as the conversation was interesting. One of the men was the landlord. He was as much a farmer as a hotel-keeper, and he was coatless and had on overalls. Another man was a house painter, who was complaining because a certain citizen would not give him the job of painting his buildings. When he came to a pause I spoke of my cornfield acquaintance and repeated some of his pessimistic remarks.

"That's straight," corroborated the painter. "A man can come here with six good horses to-day, and in a dozen years he won't have enough money to get 
226 Highways and Byways of the Mississippi Valley

out of the country. Suppose he takes land and farms it to halves; at the end of the season, after payin' expenses, the profits won't buy a bushel of potatoes. He'd be ten times better off to go up in the woods or on the railroad and work by the day."

"Now stop right thar!" said the landlord. "I've been here four times as long as you have, and I've farmed it, too, and I can tell you thar ain't a better country lays outdoors than southern Minnesota."

"That talk'll do for strangers," retorted the painter; "but, by gee! it won't do for me. My brother has got a quarter section here, and he'd starve to death if I didn't help him. Yes, sir, any renter who pays his rent and boards his family is doin' a darn big thing; and you can stand such a man on his head when he's through a season and you can't shake five dollars out of his pocket."

"Look here!" exclaimed the landlord, "the best land we got rents for two dollars an acre; and the man who can't make money on it ain't no farmer. Whar is your brother situated?"

"Four miles out on the east road."

"Oh, well, I ain't surprised now I know whar he is. That land is so cold and sour you couldn't raise quack grass on it."

The painter laughed and said: "A feller was tellin' me a quack grass story only yesterday. He claimed he lost his hat-band one summer day and he picked some 


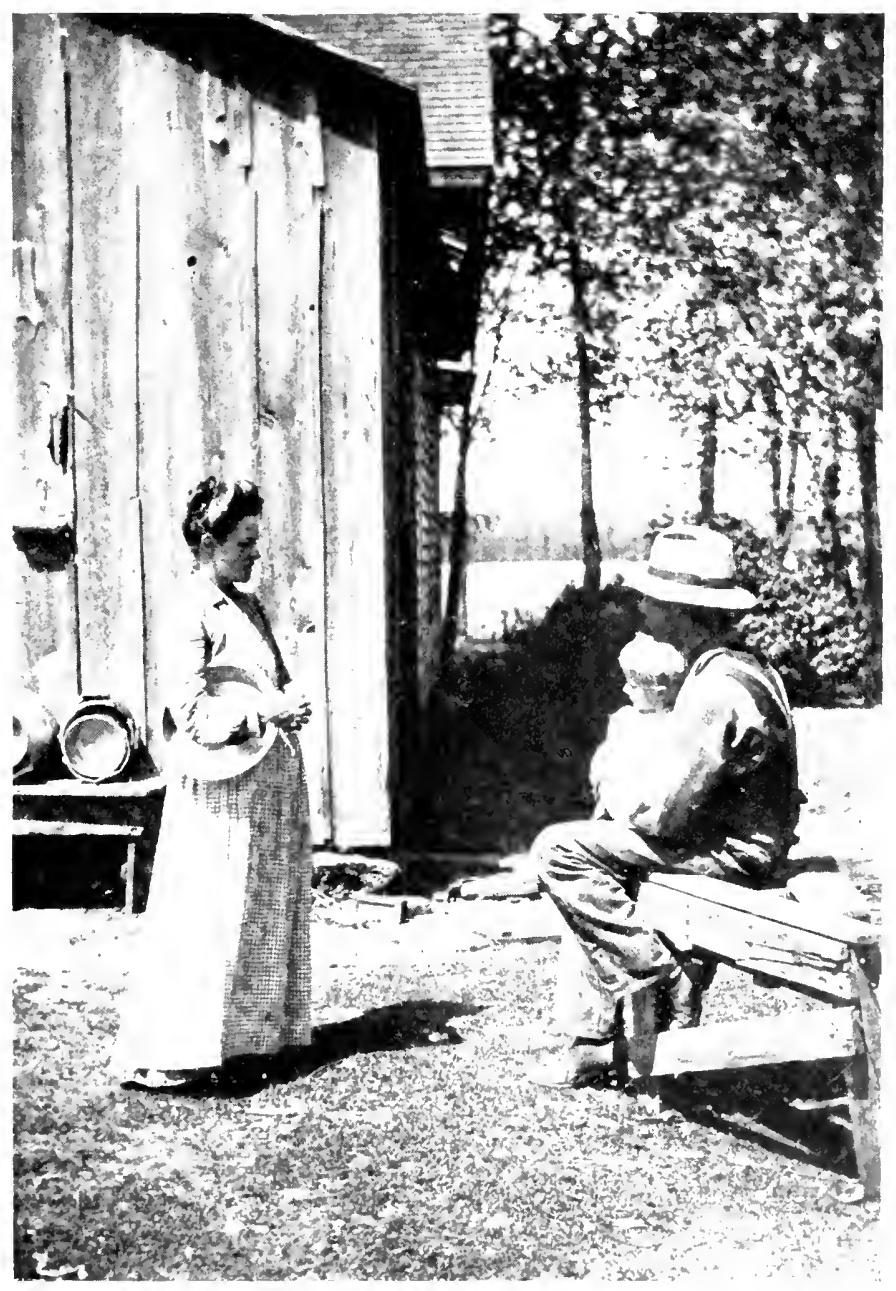

A Palse in THE I) Ar' Labor 
quack grass and tied it around his hat. When he come in at night his wife took off the quack grass and put it in the fire, and not long afterward she emptied out the ashes from the stove, and within a few days there come up a lot of quack grass where she throwed them ashes."

"You can't kill it," affirmed the landlord, "and its sprouts have got such sharp, horny points that they'll go right through a potato, or even through a pine board. You can pull up a bunch of it and hang it on a fence post, and the next year throw it down and it'll grow."

"You bet your boots it will," said the painter.

"To show you what sort of a country this is," continued the landlord, "I'll tell you what I done last year. Thar was a part of my cornfield that I raised seventy bushels an acre on."

"Not much you didn't," disputed the painter. "Thirty bushels would be closeter to it."

"I maysured it," the landlord declared, "and I'll leave it to the feller that did the husking. You know Jack Searles. He did most the whole job for me at three cents and a half a bushel; and he'd do one hundred and fifty bushels in a day. He did everlastingly rip them ears out o' the husks. Why, me 'n' my hired man tried racin' with him, and we husked like cusses; but he did five bushels while both of us together was doin' two."

"Seventy bushels to an acre!" scoffed the painter. 
228 Highways and Byways of the Mississippi Valley

"It can't be done. Must 'a' been something like an ear of corn I fixed up to show in a store window. I cut off the tip of one ear and the butt of another. The places where I cut just matched in size and I stuck a stiff piece of wire in the cobs and joined the two ears together. It looked like a single ear, and I'll be doggoned if it wa'n't more'n three feet long. Your cornfield was down by the creek, wa'n't it?"

"Yes."

"I saw it a year ago just after the corn come up, and I never see such crooked rows before in my life."

"My man planted it," explained the landlord, "and I was tellin' him we'd have to use the same horse to cultivate we did to plant because none o' the others could go so crooked."

"Well," said the painter, "you must 'a' had to blindfold the horse then to get it through some o' the rows."

"You can joke," remarked the landlord rather testily; "but I raised all the corn I said I did on that field. I can make money here, and so can others, though I will say, with the land at present prices, a man has to scratch and be a good manager to get to own it. But thar ain't one man in ten of our farmers in debt now, while twenty years ago not more'n one in ten was out of debt."

The discussion was beginning to wax hot again when one of the occupants of the room called us all to the window. A rusty, gray old man was walking past 

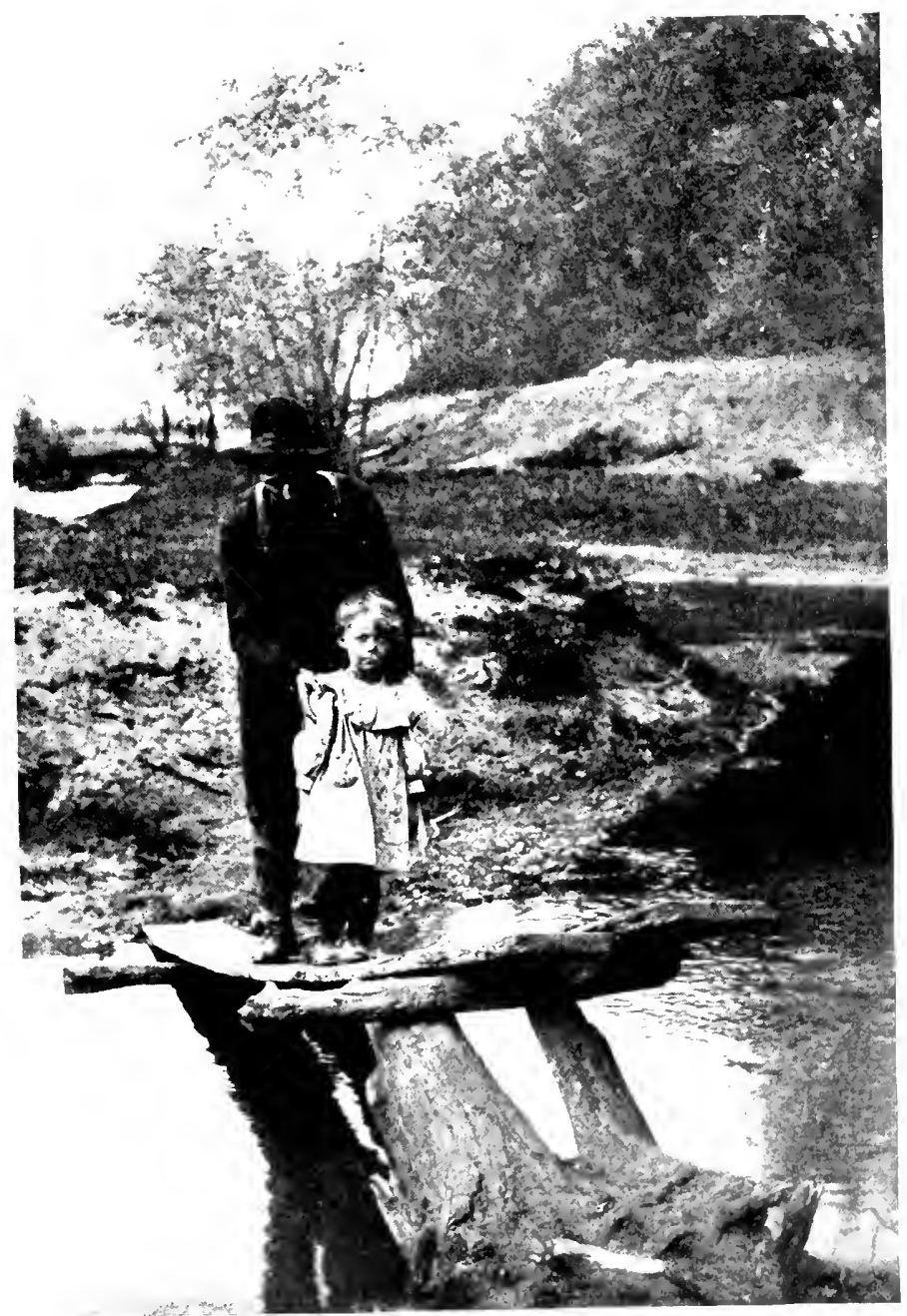

A Ristic Bridu 
accompanying a pudgy old woman. He was very attentive, and there was a touch of gallantry and an attempt to make himself agreeable that was not to be mistaken.

"Gee whiz!" exclaimed the painter, "he's a widower and she's a widow."

"Yes," said another, "that's goin' to be a match sure! His son has just married her daughter, and now the old folks are goin' to hitch."

"He was pretty well discouraged after his wife died," said the painter. "If he was haulin' a load of straw and had a tipover, or if any other little thing didn't go right, he was ready to leave this forsaken country. But he seems to have chirked up and I s'pose everything is lovely."

"If that don't beat the Dutch!" commented the landlord.

The dispute about the prosperity of the region had been forgotten; for this glimpse of romance had been like oil on troubled waters.

Note. - Any characteristic portion of our country repays acquaintance, and the prairie lands of southern Minuesota are no exception. They are monotonous, and the tourist may not be tempted to linger long, but that should not hinder getting a sample experience. Hotels in the smaller places are often rude, but rarely are actually uncomfortable, and the food, if not fine, is palatable. The country itself is in some of its aspects really beautiful, the life with its varied mixtures of peoples from Europe is interesting, and the impressions you gain have lasting value. 


\section{XIII}

\section{NEW TIMES AND OLD IN WISCONSIN}

\section{T $\mathrm{N}$ going from Minnesota to Wisconsin I spent half a day on the banks of the Mississippi. It was an unusually warm morning; but there was a}

breeze to temper the heat, and the views along the stream were very beautiful that gentle summery day. The bluffs on either side looked like mountain ranges, and their sturdy bulwarks fading away delicately blue, north and south, until they vanished in the distance, were most cheering to the eye after all the interminable flatlands which I had been seeing on the prairie country. The river itself was a much more lovable stream here than on its lower course, where it is broader and muddier and so given to tearing the banks and wreaking destruction.

When I continued my journey I went well back from the great river up the valley of the Chippewa to a town which was a country trading centre of some importance. It had a long business street lined with low brick and wooden stores, among which saloons were noticeably abundant. "Yes," said one man, "we got fourteen saloons for our seventeen hundred inhabitants, and 
they're never locked. There's some laws as to the hours they're allowed to be open; but when a man in this town starts a saloon he throws the key in the river."

$I$ arrived in mid-afternoon and the street was full of vehicles from the farms. The walks and stores were alive with people looking, visiting, and trading. Perhaps the place where most congregated was at a store in which an auction was being held. When I passed it the auctioneer was in a swelter of ardent exertion trying to get eighty-five cents instead of eighty for a piece of dress goods he was waving about with the assertion that it was worth two dollars.

The main street was parallel with the river, and the buildings on the west side turned their backs on the stream. Their rear foundations were washed by the current, and the situation in that direction was quite Venetian. The river was very low and everywhere streaked with sandbars, and these sandbars were strewn with logs. Along the shores were more logs, and there were logs lodged against the bridge piers and all other chance obstructions - thousands of them. Each Sunday there was a flood. Far up the river was a dam where the water was accumulated on purpose to "slush out the logs." When the gates are opened the river is raised about eighteen inches. Then the logs on the sandbars and shores go drifting on, and a multitude of others follow from the forests of the upper waters. The river is their highway, and they come in unceasing 
$23^{2}$ Highways and Byways of the Mississippi Valley

succession for many weeks of the spring and summer. Every season in the last forty years the stream has borne this same freightage of woodland spoils; but the land is now pretty thoroughly denuded, and as one of my chance acquaintances said, "This year practically winds 'em up. When I was a boy the logs floated so thick you could walk across the river on 'em steppin' from one to another. A few years ago there was lots o' rafts of sawed lumber went down - sometimes twenty a day. There'd be men on the rafts and every raft would have a tent on it for the men to sleep in. They'd tie up nights."

Now, only logs go down; but they are stopped by a boom and rafted when they get to where the Chippewa joins the Mississippi, and then are floated or towed down the great river to sawmills - even as far south as St. Louis.

The artificial flooding of the Chippewa is not at all to the liking of some of the residents on the banks. In the first place it made trouble with the Indians. "They had big fields of wild rice on the lowlands," said my informant, “and these was jus' bein' spoiled by the water and logs comin' on 'em. So they got ready to break the dam. They was goin' to fight, if necessary, and they took along their bows and arrows, and a few rusty old guns they had. They found three or four hundred white men ready for 'em, and there'd 'a' been a battle sure; but the lumber company made a treaty with the Indians and agreed to give 'em every 
year free gratis as much rice as they could have raised.

"This season the company is havin' trouble with a man who owns a farm where the dam is. He claims they got no business to flood his land, and he says they must pay him ten cents a thousand for all the logs they run through the dam. He says he's goin' to keep the gates in the dam locked until they agree. They offered five hundred dollars to buy him off, and when he refused it they sent a hundred men to clean him out; but be made the men a speech and the whole lot quit. Most everybody up there is in sympathy with him, because the lumber company has been pretty arbitrary and acted as if no one got any rights but them. The man has his Winchester ready, and he's put up a stone building with port-holes in it, and he and his wife are in there. Last thing I heard he'd wounded the sheriff who was goin' to arrest him, and it was expected the governor would send troops to shoot him out."

One of my rambles took me several miles up the valley. The roads were a serious handicap to the pleasures of the walk, for they were ankle deep with dust and sand. The teams I met moved at a snail's pace, the wheels ploughing heavily into the sand. Sometimes the occupants of the vehicles took pity on the horses and got out and plodded along beside them. Back from the river the land rose in steep bluffs to a 
234 Highways and Byways of the Mississippi Valley

higher level, and the roads were harder. The uplands were for the most part a great unfenced plain with wooded ridges off in the distance. There were occasional groups of farm buildings, and now and then workers and teams toiling in the fields. Much spring work was still to be done, and in some of the last year's cornfields the shattered stalks were standing as yet undisturbed. The wind was blowing, and it rustled through the dry, faded cornstalks with a shivering and lonely sort of a dirge.

Here and there along the horizon smoke was rising from woodland fires, and its pungent odor pervaded the air. Considerable damage was being done, though the local forests were not very large or valuable. As a rule the fires are allowed to burn themselves out; but occasionally the farmers go in force and try to subdue the devouring flames.

The farmhouses of the region were usually of brick or stone, snug and substantial, with numerous outbuildings. There were few trees and little shrubbery about them, and in general the landscape was singularly barren and forbidding. I could not help fancying that I was far in the north, where the chill of winter is so prolonged that the growths of forest and field get no chance to attain full development. Yet the trim dwellings and big barns seemed to proclaim plentiful harvests and a large degree of prosperity. Dairying is the chief business. Great quantities of milk are pro- 
duced for the creameries, and everywhere were broad pastures and grazing herds of cows.

The sky had been gradually clouding all day, and, as the afternoon advanced, the light faded into a gray gloom. I turned back toward the town and was fortunate in getting there ahead of the storm. We had two or three showers slapdashing around in the night, and it began raining again in the morning. The landscape was dim and blurred with the driving storm, and I could scarcely see the bluffs and trees on the opposite side of the stream.

My landlord advised me to call on a certain old gentleman who lived on the outskirts of the town and who made a specialty of collecting geological and Indian relics. "I'll lend you an umbrell," said he, in conclusion, " and that'll stop the rain. Then you'll leave it somewhere and forget it if you're anything like me. So I won't lend you my best one."

I found the person recommended at work under a shed - a white-haired countryman in a red shirt and an ancient slouch hat. Beneath the trees in his garden he had a little building packed full of his gatherings, and these he took great satisfaction in showing to me. There was no end of stones, beautiful and curious - meteorites, petrifactions, corals, crystals, and I know not what. Among the rest were many Indian implements varying from tiny bird arrows to heavy mauls and axes. Collecting had been a life- 
236 Highways and Byways of the Mississippi Valley

long enthusiasm, and his gatherings were locally quite famous.

"The teachers in the town schools been comin' here lately and bringin' the children to see the stones," said he. "They think the scholars can learn considerable that way which they couldn't learn out of books. But some of our people are afraid the children'll learn a little too much. We got one preacher in particular that claims they'll all get to be infidels because I tell 'em some o' the facts o' geology that don't fit with his theological ideas. He tackled me one day on the street to complain of what I'd been sayin' to the children about the age of the earth. 'God made this world in six days,' said he, 'and there ain't but six thousand years passed since.'

“'Why,' I said, 'I got stones in my museum a halfinch thick that was found in the ocean bed, and that couldn't ' $a$ ' been made there in less' $n$ fifty thousand years.'

“'Oh, no,' he says, 'you're mistaken. Don't you believe the Bible?"

“'Well,' I says, 'the Bible is a pretty fair middlin' sort of history of the Jewish people; but it ain't no scientific work.'

"Talking with him was a waste of breath. That feller wouldn't know beans if he had his head in the bag. He's very religious, of course; but that's human nature - the more ignorance, the more religion. 



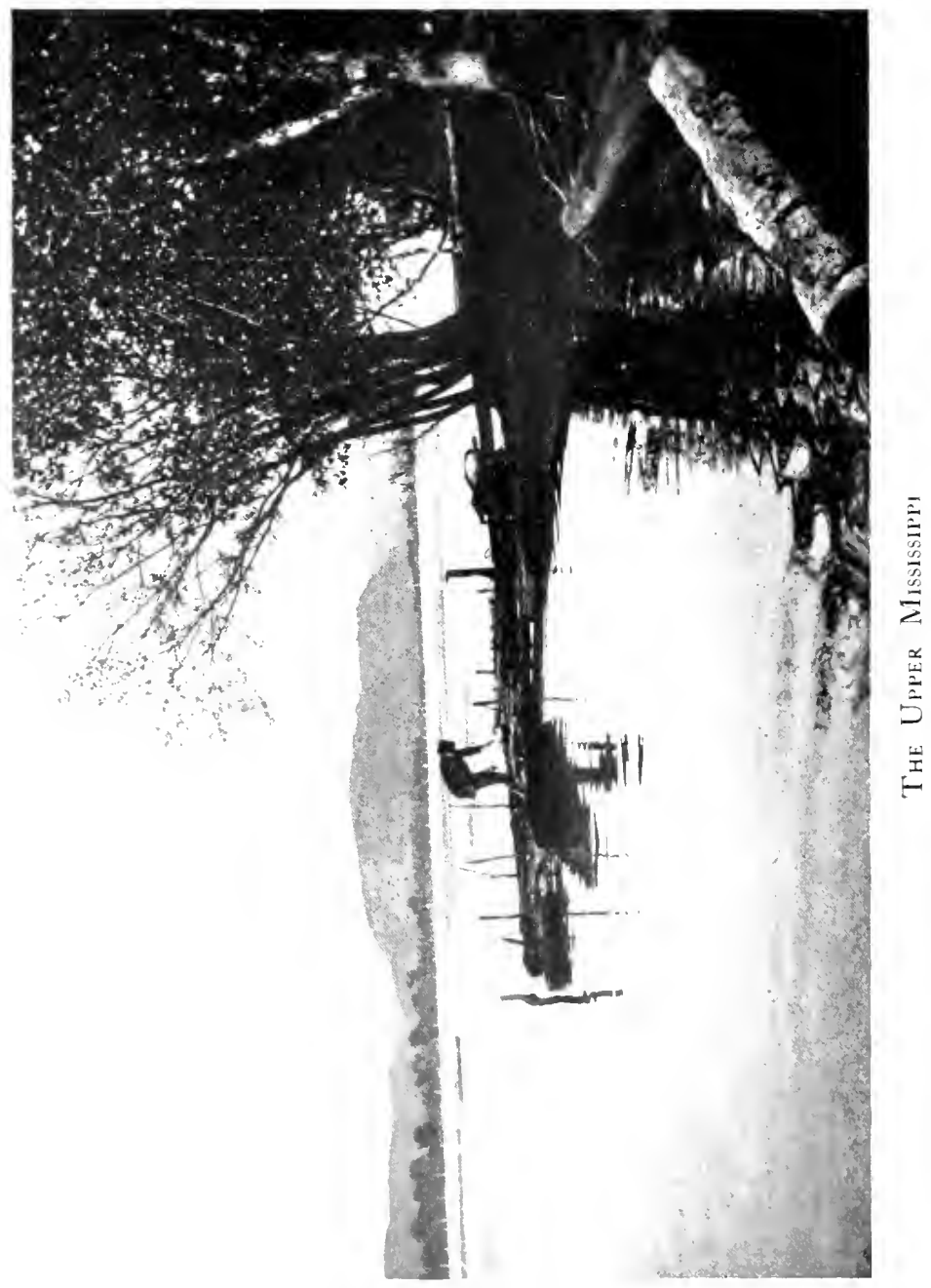


I can remember when people all thought as he does; and it'd surprise you how bigoted some o' the preachers was. For instance, there was a preacher we had in my boyhood days who made a great whoop and hurrah about keepin' the Sabbath, and he wouldn't never preach of a Sunday without givin' us a good stiff warnin' about goin' to church. He claimed the Bible would back him up in all he said. But it wouldn't, and after church, one day, I asked him a few questions and got him cornered. Then he spoke to my father and said, 'If that was my boy I'd tie him to a tree and whip him till the blood run off his heels.'

"My father had been a-listening to our talk, and he said, 'You ain't been fair. You didn't answer him, and this is the last time I'll come to hear your preachin'.'

"He never went to that church again, and I been doin' my own thinkin' ever since."

The town was still young, and there were persons living in it who had been residents from the start. Such persons liked to recall the early hardships, and I enjoyed listening to the story of their experiences.

"My folks was the first people here," said one man. "We were a month on the road comin'. Sometimes we'd make fifteen miles a day, and then again not more'n three or four. Most of our stuff was in a big canvas-topped wagon drawn by a yoke of cattle. We had, besides, a lighter covered wagon drawn by one horse. Us kids rode in that. We carried our food, 
$23^{8}$ Highways and Byways of the Mississippi Valley

and when we run short we could buy more; for the country was settled some until we got most here. The roads was pretty bad and the last part of the journey there was nothin' but Indian trails. The woods was full of fallen trees, and often we'd have to chop 'em away in order to get along. When we come to a stream we usually had to ford it, though sometimes there'd be a ferry.

"People movin' like that was in the habit of goin' in companies of from two to half a dozen families. We had several other families goin' with us, and whenever some wagons got ahead of the rest, the people that was in front would every now and then write on a slip of paper and put it on a stick side of the road tellin' when they passed. We always tried to camp where we could get water easy. If we found a good stream in the middle of the afternoon we'd stop there, for fear we wouldn't do as well later. We'd build a fire on the ground and get the kittle boiling, and perhaps we'd ketch a mess of fish. Some nice evenings we'd sleep on the ground or in a tent; but generally we bunked in the wagons.

"When we got here we put up a log house. The walls was of logs, and we split logs for the floor and for the roof and window-casings and doors. Our chimney was made of mud and sticks. We didn't use any nails or iron worth mentioning in the whole job. Wooden pins did for nails, and leather straps for door hinges. 



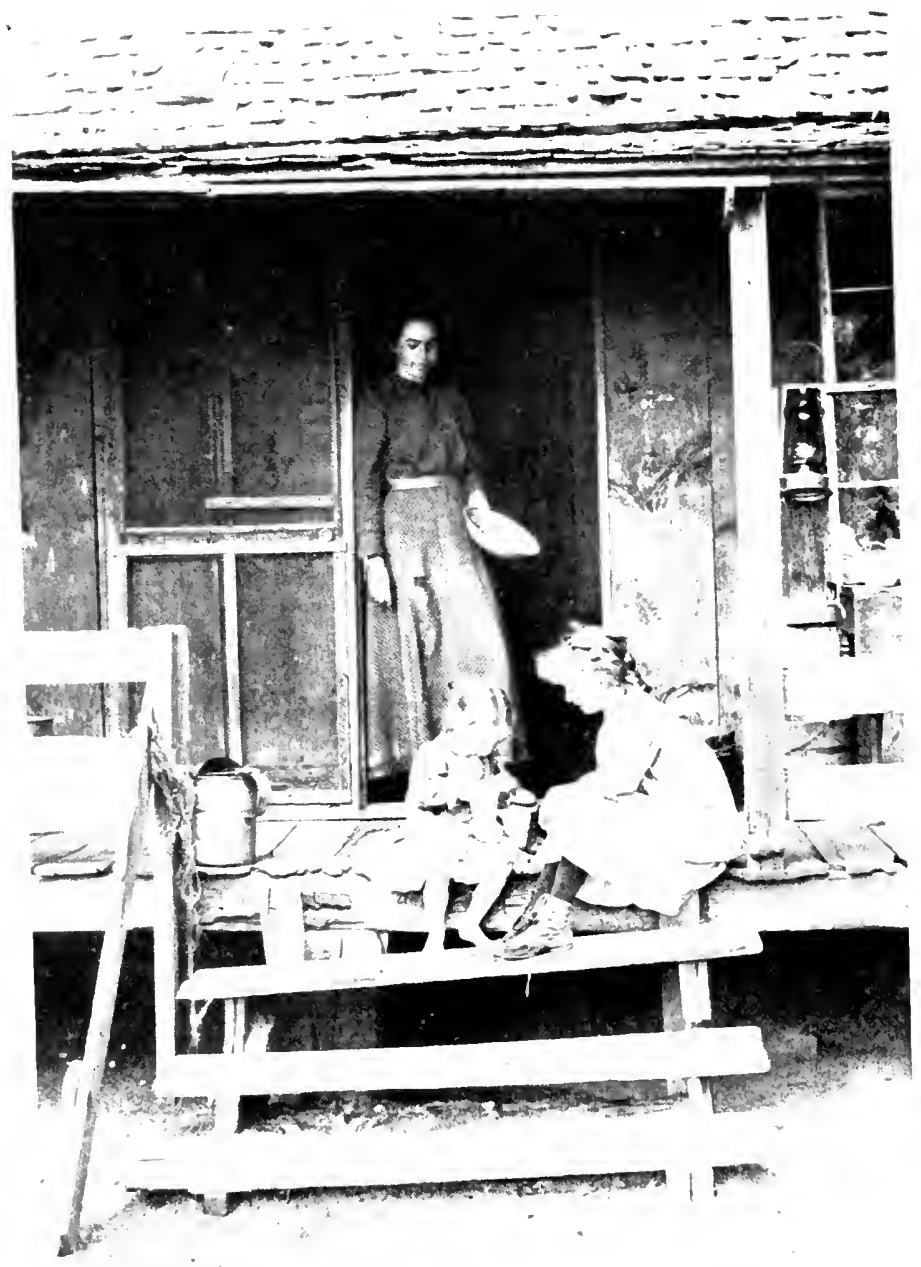

At ThE Back Dook 
The latches for the doors was wooden, and a string was hitched on to the latch and run out through a hole above. When you wanted to come in, you yanked the string and that lifted the latch, and you only needed to pull in the string and the door was locked.

"Well, there we was, a few families of us, and the nearest settlement was Reed's Landing, down where the Chippewa joins the Mississippi. We had horses and oxen, but no roads, and we had to get our supplies from Reed's Landing on foot. The distance was only twenty miles; but it would take father two days to come back with a sack of flour on his shoulder. The flour made a big load and he'd go pokin" along pretty slow. At night he'd stop and build a fire and roll up in his blankets and go to sleep. That winter we had the most snow I've ever seen. It lay four feet on a level and the drifts was ten feet deep. When we run out of grub and father had to go to Reed's Landing, he'd put on snowshoes and drag a sled after him with his gun strapped to it.

"We did without most everything that wa'n't absolutely necessary those first years. Pork was twentyfive cents a pound and other things in proportion. We had just one hen, and the eggs she laid was worth a dollar and a half a dozen. So we didn't eat 'em, but exchanged 'em for coffee. We generally had bread, though it wa'n't half the time we had wheat flour. Corn-bread was the standard. Venison was plenty. 
240 Highways and Byways of the Mississippi Valley

A fellow could go back here on the bluff any time and kill five or six deer in a day. I've seen deer run through the streets among the log houses and wooden stores. It was no excitement at all to see one swim across the river. Sometimes we'd run out and take a boat and foller after the deer and kill it with a paddle. The winter of the big snow a man could go on his snowshoes and knock the deer down with an axe.

"We used to lay by a good deal of dry venison. We'd first salt it down for a few days, and then hang it by the kitchen fire to dry. The dried meat was called jerked venison. I can remember settin' on the doorstep eatin' it when I got hungry between meals. Us kids was eatin' all the time. Everything tasted good then. When you get older your appetite goes back on you; but you most likely think there's a difference in the cookin'. You say to your wife, 'Gosh, darn it! my mother use to cook food that was good.' But it wa'n't the cookin'! - it was your appetite that was good. These little rascals knocking around on our streets are ready to eat anything and enjoy it, and so it will be always.

"One food we had regular was hominy. We'd sit up nights to shell the corn. To take the hulls off we'd boil it in lye, and after that, it was boiled in water to get rid of the lye. Then it needed to be renced three or four times and was ready for a little seasonin' of 
pepper, salt, and lard. We had fried hominy about every mornin'.

"Do you know what pumpkin butter is? We made it by boiling the pumpkins in a big kittle, then squeezing the juice out in a press, and straining and boiling it down. Perhaps it would be thickened some with apples. You spread that on a piece of bread, and you'd think it was the only thing in the world.

"There was no beef or milk to be had at first; but more people was comin' into the country all the time, and they soon brought cattle and begun growin' potatoes, and then we was all right. We made roads, too, and the lumber companies got a-goin', and the logs and rafts was floatin' down the river. To get our supplies easier the people here built a keel boat forty feet long and ten wide, and they use to pole it down to Reed's Landing and back. When the wind was right they'd put up a big sail. It took four men to handle it, and they was several days comin' back against the current.

"Of course there was Indians around; but they was perfectly friendly at first. They would come to our house now and then and ask for something to eat. Mother'd give 'em a slice of bread spread with lard. We didn't have no butter - didn't know what butter was. They were great beggars, and they'd steal anything they could lay their hands on - I've been to their villages and inside of their wigwams. The wigwams had a frame of sticks set up cone shaped and covered 


\section{Highways and Byways of the Mississippi Valley}

with hides, and they always was dirty and had a smoky smell. When a family got hungry they boiled up a mess of meat, and each of 'em would set down and eat a chunk. They didn't wear much clothes in summer; but in winter they had a full suit of buckskin, and put on leggings, moccasins, and blankets. Most of 'em scratched over a little ground and raised a few pumpkins and some corn. They ain't got the ambition to do any more than that, even now. The fact is, you can't civilize an Indian. They're just like a partridge. It's their nature to be camping out. You can educate them as much as you please, and they'll go wild again and get back to their old ways and haunts.

"In I 857, I think it was, when I was about eight years old, the Chippewas and Sioux fought a battle here. We saw the two parties arrive late one day, and we knew at once there was goin' to be trouble and was well scared. All the whites got together in the biggest and stoutest log house. About dark I slipped out and went down by the river and hid where I could look on. I got near enough to one of the parties so I see their war dance. They formed a circle with a feller settin' in the centre poundin' a drum, and while they danced they sang in a kind of monotone and waved around their guns and bows and arrows and tomahawks. It wa'n't long before the fighting began, and some Indians was in canoes and some on the bank, and I saw 'em killin' and scalpin' each other. Pretty soon father 


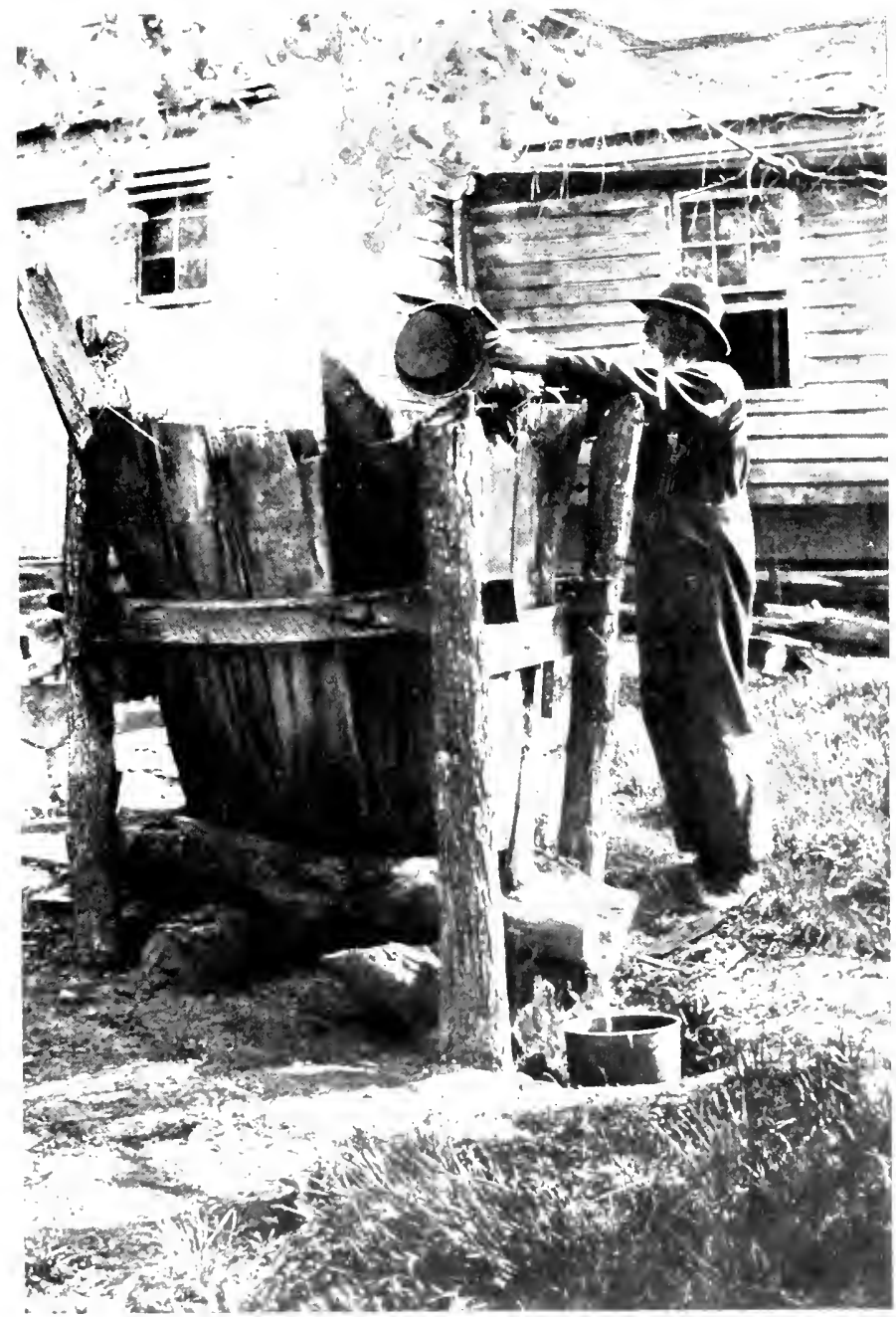

Makive, I, je for Som-soal 
come lookin' for me, and he give me the worst lickin' I ever had.

"There was lots of elk when we first come and quite a few moose and plenty of timber wolves. Week before last a feller brought to town seven little wolves he'd caught back in the woods. It was a good haul, because there's a bounty of six dollars apiece. I hear every little while of some farmer who has lost sheep carried off by the wolves. I've had 'em kill calves of mine a year old. I come across five or six wolves chasin' a deer through the woods once. They had it jus' about petered, and when it come opposite me they downed it. Then I stepped up and they all run but one. I fixed him with my gun and got the deer. They hadn't harmed it any but the throat, and I cut off what meat I could carry handy, and the rest I hitched to an iron-wood sappling that I bent over and then let it swing up into the air. That hoisted the carcass out of the wolves' reach.

"A wolf is a funny animal. You find a nest and handle the young, and the old wolf will go off and desert 'em. When we was new to the country we was afraid of the wolves; but we soon got used to their ways and learned there was nothing to be scared of. Even if you are alone and it's night they won't touch you if you've got a fire built. I wouldn't mind meeting eight or ten of 'em if I had a good club. Ordinarily they'll run from you; but they might attack you if they 


\section{Highways and Byways of the Mississippi Valley}

was very hungry. I've never had any trouble with 'em, and I been out all sorts of times and places. If you're passin' along a lonely road after dark you'll hear 'em howl to get their gang together. They know you are there, and somewhere off on the bluffs they'll be answering one another; but after they've sized you up they'll go away.

"We had wildcats here - oh, Lord, yes! And we had bears; but bears are harmless beasts. Of course, corner one up or get him in a trap and he'll fight. Even a deer'll fight in such circumstances. I've had 'em raise up in a huckleberry patch and look at me; but they didn't offer to do me no harm. I'm often asked if bears ever chase any one. Well, I've heard people say so; but I didn't believe it. We had bear meat frequent to eat. It had a wild taste; but if the creature was young and fat, the meat was mighty good. I'd like a nice chunk for supper to-night - you bet your life I would.

"Squirrels was numerous, and they are now. I went out here last fall and shot three or four off one tree. There was lots of beaver, especially on the small streams, and there are some left still; but they're a cute animal, and you would have trouble findin' 'em. We did a good deal of trappin' in the old days. Quite a few follered that as a business. October and November was the best months, but the early spring was good, too. Most of us set traps on the cricks and went to see 


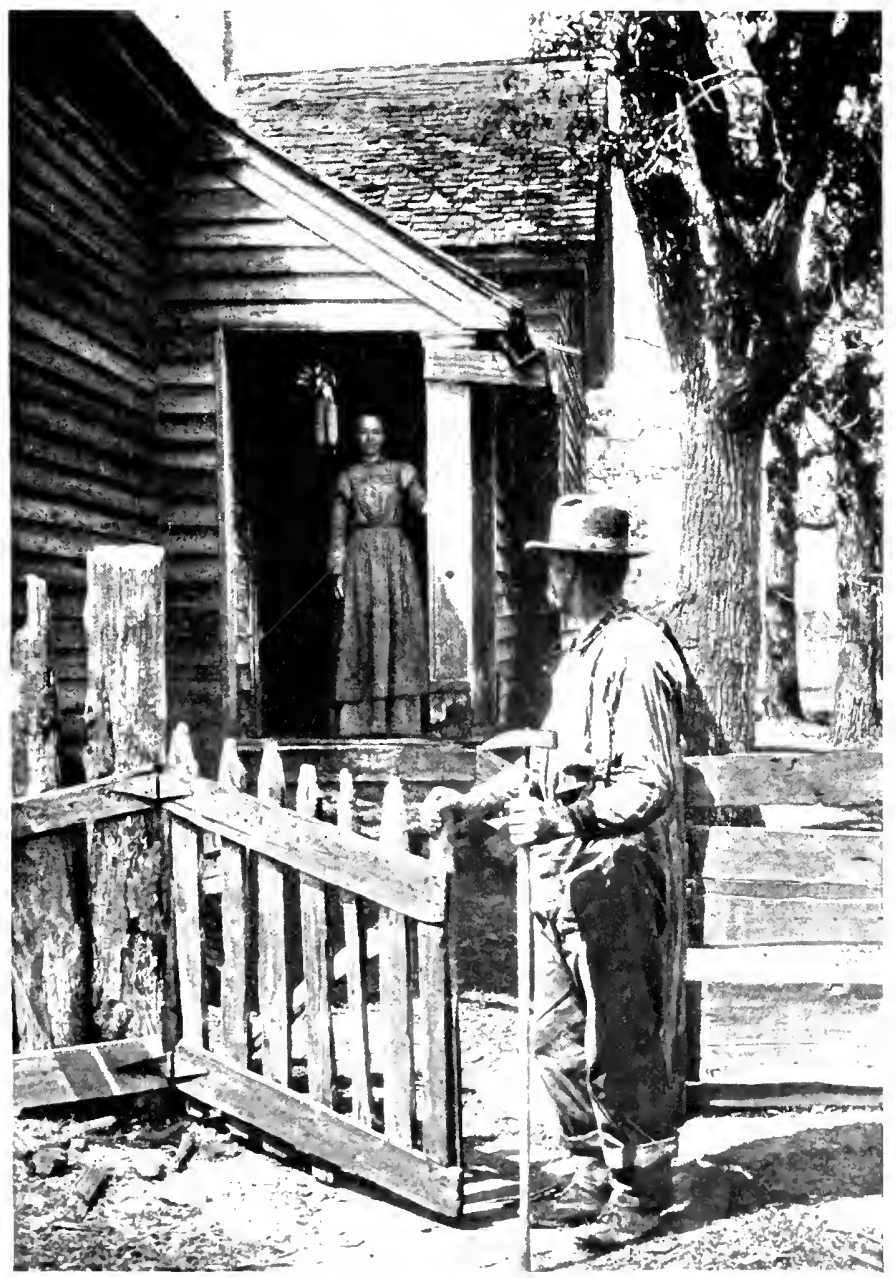

STARTING For Work 

what we'd got every day. Some fel'ers would build camps on the shores of the wild lakes and stay there to hunt and fish right along durin' the season. The fish was ten to one what they are now - yes, a hundred to one. I could go down here to the river, and in five minutes ketch the finest string of black bass you ever set eyes on. At the mouth of the little crick near our cabin I've ketched of an evening a hundred pounds of pike and pickerel with no trouble at all. And talk about trout - every brook was full. It makes me lonesome to think about how few there are now.

"Within three years after we settled here the place had grown to quite a village, and there was a store, a hotel, and a sawmill. We was jus' thinkin' we had got well established when there come a flood that pretty near cleaned us out. It was in May after the snow was all gone, and the rise was caused wholly by heavy rains in the north. We slept upstairs, and the river rose so in the night that next morning when father come down he stepped off the stairway into the water. He hurried and got a flatboat he had, and we put what goods we could in it and went to the bluffs. All the cattle and pigs was drowned, and the booms broke so the river was full of floatin' logs. The logs punched through the house walls, and some of the cabins was tipped over, and ourn was carried away. After the flood was past we straightened up what buildings was left and moved 'em to higher ground. 
246 Highways and Byways of the Mississippi Valley

“We was soon prosperin' again. It was easy pickin' up money then. I've seen the day, my friend, here in this town, when you couldn't get a man to do a day's work for you. Everybody had plenty of money and they wa'n't anxious to work for any one but themselves. Well, sometimes you can't get a man now. It's almost impossible to get one on Sunday to do a job for you. 'I'll come if it rains,' he'll say; but otherwise he'll be out on the water or monkeying around with the girls.

"We used to be more dependent on ourselves — did our own spinning and knitting and all that. Lots of people back in the country spin yarn yet and knit the family stockings and mittens, and they often knit to sell to our choppers and teamsters. The things they knit are good and thick and jus' right for people who are out in the cold much.

"Mother used to fry out the grease from the bears, deer, and coons we killed and make it into candles; but sometimes we'd run short of candles and have nothing better for a light than some grease in a dish with a rag set up in the middle. We thought coon grease was specially good for boots. I've seen my boots so darn stiff when I got up in the mornin' I couldn't get 'em on until I'd give 'em a good rubbing with coon grease. It was our idea the boots lasted longer if we changed feet with 'em every day, because what they'd run over one day they'd run back the next. 
"Mosquitoes bothered us a good deal more than they do now. You see there was no such thing as netting to keep 'em out. We had a regular smudge kittle fixed with a hole near the bottom to make a draught for the fire that we'd start inside. When it was smokin' good we'd carry it through the house. I've known father to get up in the night when the mosquitoes was real bad, and spread some powder on a dish and touch it off. The mosquitoes couldn't stand that kind of a smudge. "Every spring we'd go across the river three or four miles to a camp in the woods to make maple sugar. We had a log shed there, open in front, facing our fire. We'd tap a thousand trees. I c'n remember just as well as if it was yesterday the sumach spiles we used, and the basswood pans we chopped out to catch the sap, and all about it. We fixed up a sort of oven with stones and clay, and set on it a shallow pan we made out of sheet iron, with board sides. Then we found the biggest basswood we could, and cut it down and chopped it out into a trough twenty feet long to hold the sap when we brought it in from the sugar bush. An oxteam would be busy all the time hauling. The oxen were hitched to a draw made of a heavy tree crotch, shaped with our axes into a rough sledge. On that we set a hogshead. The basswood trough was propped up on blocks, and there was a little trough connecting it with the boiling pan, so we could run in more sap as it was needed. Some of us had to be on hand all the 
$24^{8}$ Highways and Byways of the Mississippi Valley

time, for we kept the boiling going without any let-up. We'd take turns standing watches during the night.

"After we'd got a mess boiled down to syrup we'd strain it through a cloth. Then we'd put it in a kittle we had hung from a pole laid on two crotched sticks over an open fire, and boil it down to sugar. The sugar we made into cakes, and some of it we sold, and the rest we used. It was the only sugar we had. The last run of sap was rather poor, and we'd save a couple of barrels of it partly boiled down and take it home and leave it in the yard with the bungs out of the barrels. It would turn into the best kind o' vinegar. Sometimes we'd pour a little of the hot syrup on the snow and it would form into a kind of gum - very sticky and very sweet. Once a feller who had false teeth come over to our camp and tried some of the gum. It pulled his teeth loose and he was an hour gettin' 'em in order again. Lord Harry! we had lots of fun over in the sugar bush. In the night the bears and wildcats would come prowlin' around and carry things off if we wa'n't careful.

"We could easily get all the honey we wanted. If you happened across a bee tree you jus' cut your initials on the bark, and that was a sign it was yourn, and if anybody else happened to find it he wouldn't meddle with it. You could come and cut the tree down and chop the honey out when you was ready. Now and then we'd hunt for bee trees by goin' out in the 
fields and puttin' molasses or somethin' sweet on a block. Pretty soon a bee would find it and fill up, and when he started for home you'd track him. After father had cut down a bee tree he'd put the bees in a box and take 'em home, and they'd go right on makin' honey. I want to tell you, brother, it was just a delight to be a boy here then.

"Our first school was kept in the houses, right through the village, taking every house in turn where there was children; and at whatever house the teacher was havin' school there she boarded. The first building put up for the school was of logs chinked with clay. We had no desks, but sat on backless wooden benches and held our books in our laps.

"As I grew older I had my best times at the dances. Winter was the dance season and we'd go somewhere two or three times a week. We'd start early and take an ox-team and fill the body of a big sled with straw and blankets and all pile on and ride to the farmhouse where we had been invited. We didn't put on no style. All a feller needed to do was to get his overalls washed so he could slip 'em on clean; and if a girl wore a new calico dress she was a dandy. A violin furnished music for the dancin'. Most generally everybody baked up some food to take, and along about midnight we'd have a feast of bread and butter, cake and pickles, and there was a chunk of boiled pork from which we sliced off what we wanted. 
250 Highways and Byways of the Mississippi Valley

"While the town was new it was kind of a rough place. You could see a fight any time. The 'general store' kept a barrel of corn whiskey in the cellar or back room, and was ready to fill a pint bottle or a gallon jug for whoever wanted to pay the price of it.

"The people that come in here early was religious, and my mother learnt me to say my prayers when I went to bed. We soon had a preacher, and he was a good one, too, though he had to get his livin' mostly by workin' in the fields. At first we met in one or two of the larger houses for our prayer meetin's and church services; but later used the schoolhouse. Once we had a revival and I attended it with my girl. She got quite excited, and before I knew what was happening she started for the mourners' bench. She didn't ask me if I'd go. She jus' got up and went all by herself. Well, she kneeled down there, and I see right next to her a feller kneelin' she'd been goin' with some and who was a rival o' mine. I said, 'By gosh! I can't stand that! Maybe he'll be ketchin' her.' There was jus' a little room between her and him, and I stepped up and kneeled so as to separate 'em.

"I cut him out that time, and he didn't marry that girl. As far as that goes, neither did I. Oh, well, you can't be young but once."

Note. - At any town of reasonable size you will find a good hotel, and when you are once lodged to your satisfaction you can proceed to get acquainted with the country around in your own way. 


\section{XIV}

HOUSEBOAT LIFE

$\mathrm{F}$ all the dwellers in the valley of the great river, those who live in the houseboats have by far the most picturesque environment. You find them everywhere from St. Paul to New Orleans, and not only on the main river, but on all the larger tributaries. There are many thousands of these water-gypsies in all, though the number fluctuates, and in winter the northern regions are pretty much deserted by them. Sometimes you may see a score or more boats in the neighborhood of a single large town, and again, the flotilla may be reduced to a half dozen.

The boats vary surprisingly in size and architecture. Every man builds according to his means, his chance whims, and the material he may have at hand. Some boats are hardly bigger than an ordinary skiff and are roofed with canvas stretched over hoops. The dwellers crawl inside as into a hole in the ground. Other boats are large, convenient, and attractive, and make homes by no means to be despised. They have several rooms, and very likely "are as nice inside as the parlor in anybody's house." One such craft was pointed out to me 
252 Highways and Byways of the Mississippi Valley which had cost fifteen hundred dollars. But the vast majority cost less than one hundred dollars, and many not half or quarter that sum. A large portion of the necessary materials can be picked up along the river without expense; for boards, plank, and timbers are always being carelessly lost into the water by the men who handle them on the scows and about the sawmills. The river people themselves commonly call these floating homes "shanty-boats," and that indicates their general character. They are mostly rudely built in the first place, get little care, and in a few years go to pieces.

One of the first that I investigated was at Baton Rouge, moored by the shore just aside from the wharves. The house part was a single room about $\$$ by 12 feet, and the family consisted of a man and wife and two daughters. They said they had been living on a larger boat, but the bottom "got bad," and it sank. The wreck was close by, half submerged. The people were from the North, which they had abandoned because the woman's lungs couldn't stand the cold. The houseboat afforded a cheap means of shifting to a kindlier climate, and also served after they got South as an economical home. There were no taxes to pay, and no rent; you could catch your own firewood, and with hook and line supply a good share of your own meat, and these were no mean advantages to a family in straitened circumstances.

A good many boats have a paddle-wheel at the stern 


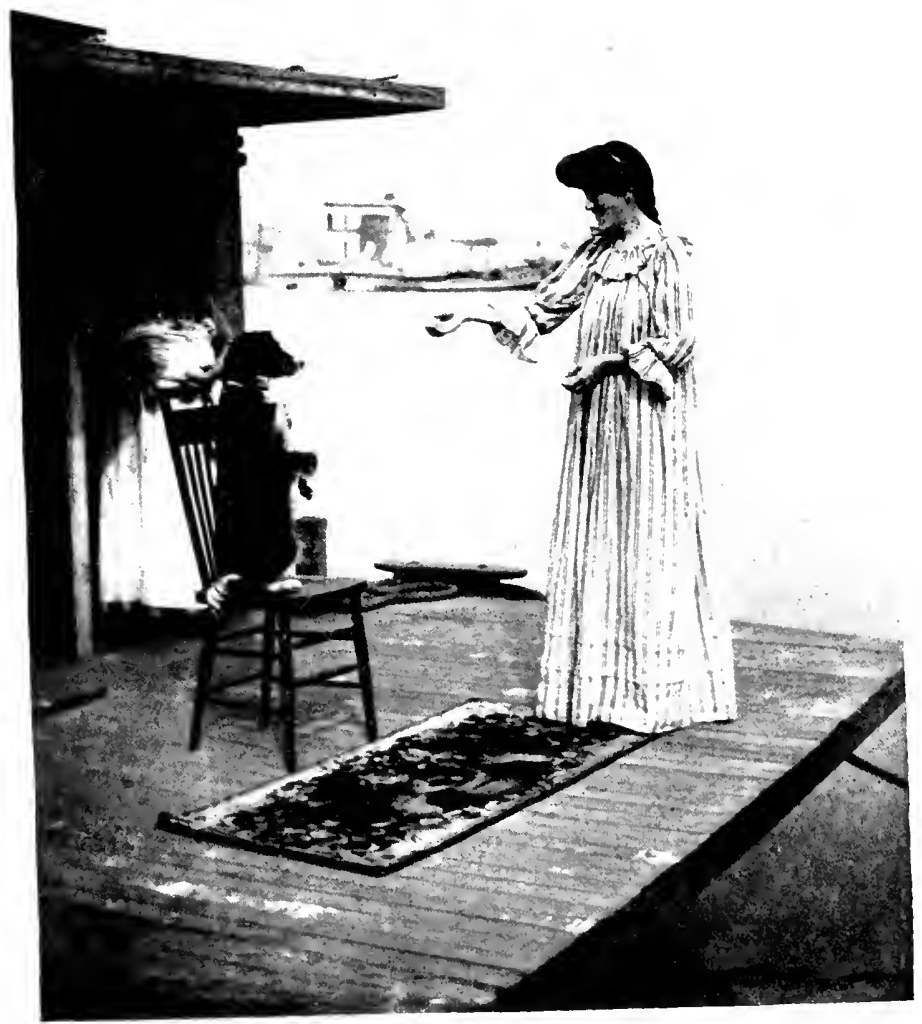

A House-boat Dog: 
and gasoline power, and go where they will, quite independent of the rest of the world. Such boats do considerable business as tugs, towing other boats, barges, and rafts, and doing whatever small jobs come their way. Certain of these gasoline craft are floating sawmills and are known as "drifting boats." In every bend of the river is lodged an enormous "drift" of floodwood - "millions of cords," explained a Cairo man. "And some drifts are a mile across. Why, there's enough firewood in the drifts between here and Memphis to supply the whole United States for six months. The drifting boats make considerable money dragging logs out of the mass, sawing them into boards, and selling the boards at the small towns along."

There are various other ways to make profit out of the river wreckage. Some men do a good business rescuing the ownerless trash that is afloat and working it up into cord-wood or sawing it into stove length. In New Orleans you often see miniature woodyards on the wharves, and I heard of men who "got rich" there selling stove wood they had manufactured from the river rubbish, twelve sticks for a nickel.

I saw at Vicksburg an allied industry, which was the conversion of stray cypress logs into shingles. The logs, as they were caught, were tied alongshore, and, lying there in the water, were laboriously sawed into sections of shingle length. When a section had been sawed, it 
254 Highways and Byways of the Mississippi Valley

was rolled up on the shore and split into moderate-sized blocks, and these were reduced with frow and maul to shingles in the rough. After that the shingles only needed a little shaving to smooth and taper them, and then could be packed and were ready for sale. Several shingle-makers were established alongshore, all negroes, and each man doing business on his own account. They had rough little shanties to work in when the weather was not favorable. I tried to find out something about the rate of production by this antique method, but the old shingle-man with whom I talked, said, "I never tried an experience to see how many I could do in a day."

He affirmed that he only got a bare living out of the work, and added, "I'm a poor man, but I got a proud mind. If I had de money accordin' to my mind I'd be all right, I do believe. What I want now is to see de river fall like de bottom gwine to drop out. I want it to git off de farmers' land. Dey ought to be plantin'. If de water keep on disaway, dey won't be prosp'rous, an' den dey cain't buy shingles.'

About this time a colored woman came down to the shore laden with a basket and bundles and prepared to get into a boat. Some distance off across the water was an island, and among the bushes over there were a number of houseboats, in one of which the woman lived.

"How's yo' man?" asked the shingle-maker. 


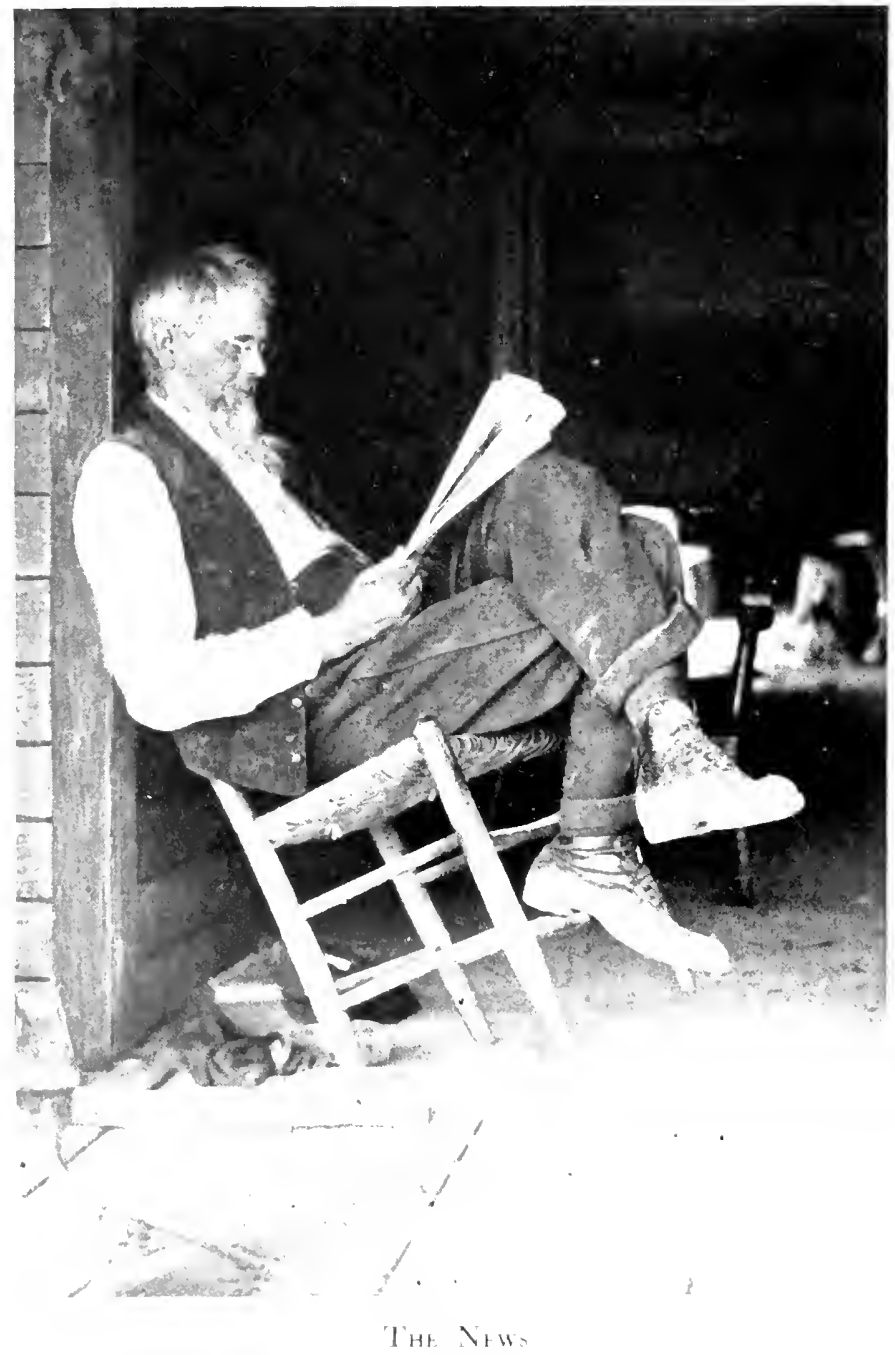


"Oh, jes' so-so," was the reply.

"He been laid up a long time now."

“Yas, an' when I think how many been took sick an' died since I begun takin' keer o' him, I wonder dat he am alive."

“'Hit yo' good nussing, sister. Dat's better'n a whole lot o' dis hyar strong doctor's medicine."

"I know it; but dar's spells when I'm afraid I git worried to death he feel so bad an' miserable all de time. Hit seem like he not got any kind o' patience. He jes' draggin' aroun' complainin', an' he tell how heaven is de lan' of rest, and he ready to go dar. He say he doan' never want to be ole unless he gwine to git well."

"Yo' mus' cheer him up, sister," advised the shinglemaker. "Tell him he gettin' along as well as could be expect. Hit never do to disencourage a sick person. Dey die den anyway."

Two of the old man's boys, not yet in their teens, were with him and aided him more or less, but put in most of their time playing and idling. They were not interested in the conversation with the houseboat woman, and they talked about other matters. For instance, the older boy asked this curious question, "Ain' yo' never seen a muskeeter settin' on a tree an' bark ?"

"Co'se I hain't," was the reply.

"Well," said the first boy, "if he set on de tree he got to set on de bark too, ain't he?" 
256 Highways and Byways of the Mississippi Valley

The other boy could not dispute that proposition and after a little discussion, the first boy challenged his comrade with the remark that he could make him say "black."

"No, yo' cain't," declared the second.

"Yes, I kin - what de colors of de American flag?"

"Red, white, and blue," responded the second boy.

"Dar, yo' said blue!" exclaimed the first.

"But yo' tol' me yo' make me say black," the other protested.

"Well, yo' done said black now," said the first boy triumphantly.

There was an unusual number of shanty-boats along the Vicksburg river-front. The skipper of a gasoline craft said most of them were there on account of high water, but they would all "skedaddle" away when the river resumed its normal level. As for himself, his boat had been bringing wood from the "bayous and swamps," and he had "got a pretty good dose of malaria back there," and was waiting till he felt better.

At Memphis was another flotilla of houseboat refugees; but here many landspeople were among the boat dwellers. A crevasse had broken in the levee across the river, and a vast amount of country was flooded. Five thousand people had fled to the Memphis bluffs, and some were living in tents along shore, some in improvised huts, and some in houseboats. "It's like an ocean over thar," said one of the boat inhabitants - 
"no land anywhar. I tell you the farmers has a hard time hyar in the Mississippi valley, and I'm afraid the South'll jis' natcherly be ruined. I had a farm till last year. That was the worst year ever known in the history of the world, I believe. The flood come in March and kept raisin' and raisin' till it was higher'n we'd ever seen it. I had a big fine house that cost six or seven hundred dollars. It was on posts five feet off the ground, so I thought it was safe; but the water got into it and I had to make scaffolds to walk around on. Finally the water was most up to the eaves, and then come a wind with waves ten feet high that smashed the windows and knocked down my scaffolding and set tables and bureaus and everything afloat. It was distressin'! - awful! We had such a storm that ever'one thought me 'n' my ole woman was gone up.

“Lots o' people were drowned jis' like rabbits, an' a good share o' those that lef' their homes an' got away had to camp on the levee. It was a dreadful, cold, stormy time of year, and thar was sickness an' accidents an' many deaths from the exposure. Thar was no way to git coffins - no way to git nothin' - and they had to sew the bodies up in sacks with sand enough put in to make 'em sink, and then they'd throw 'em in the river. One woman whose brother was buried that way went crazy.

"For our cattle and horses every farmer had to build a raft - what we call a stock stomp. We'd have a 
$25^{8}$ Highways and Byways of the Mississippi Valley

fence around it, but the critters would be pretty well crowded on it and they'd git to fightin' an' hookin' an' push each other overboard.

"When the water went down thar was eighteen inches o' mud in my house. It looked like the home of a dirt-dauber. I bored auger holes in the floors to let the water drean off, and me 'n' three niggers worked two days to git the mud out. My furniture busted to pieces or warped, so we couldn't hardly use it, the floors swelled out of shape, the paint was ruined, and the stuff we'd stored in the loft was all mildewed. It was discouragin' work tryin' to dry things out.

"The farm was all cut to pieces and covered with sand ridges. I wouldn't rent it ag'in, and the man that owned it had to take care of it himself. Usually, you could get three hundred dollars' worth of watermelons off it and twenty bales o' cotton and a thousand bushel o' corn. Well, he planted watermelons, but they all burnt up before they got two inches high. Cotton, he didn't try, and he only got forty bushel of corn, and that was nothin' but nubbins - calf feed.

"I'd had enough, and reckoned I was ready for a change of residence. After a while I had a chance to buy a good boat hull for two dollars, and by spending twenty more I built me a fine boat. I could sell it easy this year for a hundred dollars, and lots o' these drowned-out folks would jump at the bargain."

One of the boats near by where we stood talking had 


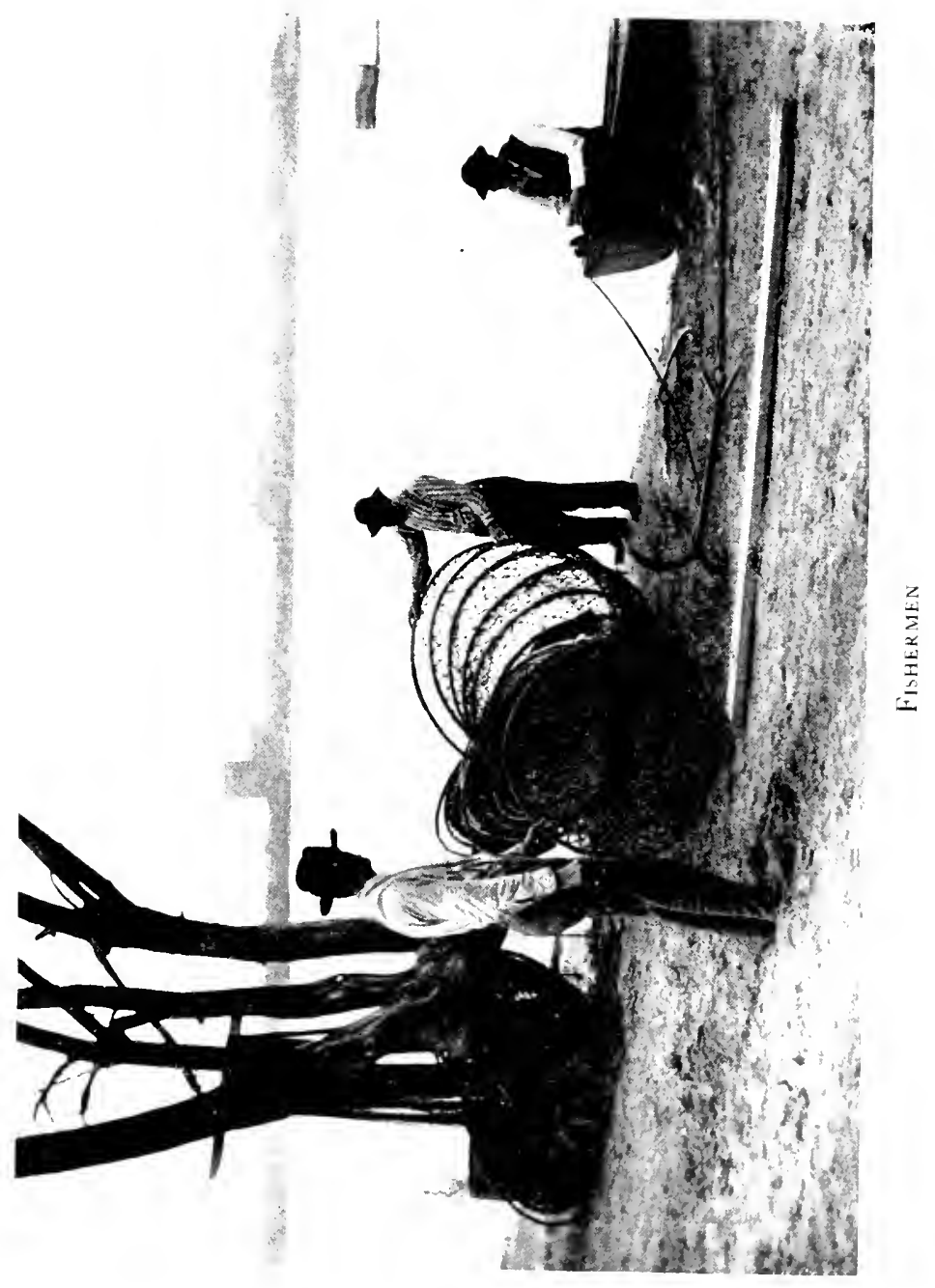




\section{Houseboat Life}

a sign painted on the sides - "Medicines for Sale." The peddling boat is a recognized institution, and some of them carry a general stock of merchandise worth five or ten thousand dollars. Then there are the "show boats," the best of which are "floating-palaces" to the eyes of the average valley dweller. "They have talking machines on board," said the Memphis man, "and music and dancing, and they act plays. Some of the big ones can take on several hundred people. These opera boats travel all the year round. In summer they're up among the Pennsylvania mines and Northern cities, and in winter they're among the great plantations and towns of the South. Nice reserved seats cost seventy-five cents to a dollar and a half; but most of the seats are jis' benches and only cost a quarter."

Still another type of houseboat life is to be found in the "River Revivalists." "They keep on the go, too," declared my Memphis friend, "and they stop at landings along and advertise meetings on board. I ain't much confidence in 'em. Some are only fakirs. I've seen considerable much of ministers, and I've made up my mind that generally, ashore or afloat, they've taken up their callin' as a business and are workin' for what thar is in it. They beg every time they look at you. The mo' money you got, the bigger Christian you are. Yes, sir, you shove up five dollars to the preacher, and you c'n drink and cuss and rip and tear all you please." 
260 Highways and Byways of the Mississippi Valley

The houseboat industry that furnishes a living for the greatest number is fishing, and few of the larger towns on the river are without some of these houseboat fisher-people. I became especially well acquainted with them at the mouth of the Ohio. Most of their boats were moored near the Kentucky shore, and in order to visit them I rowed across the Ohio in a rough little skiff I borrowed of a Cairo shanty-boat man. It was a one-mile pull through a yellow flood streaked with driftwood. A brisk wind blew and the waves heaved and now and then broke into a whitecap. At length I reached land, tied my boat and followed the shore up-stream on foot, passing in places through dense groves of cottonwnods and again along strips of exposed beach. Both among the trees and outside were shanty-boats and a variety of little dwellings, the latter all on stilts, perched well above the clutch of the floods.

The boat families often had chickens, and owned a dog or two and possibly a cat. All these creatures get used to their floating habitations and accept them as the natural thing. One man pointed out to me three chickens about a fortnight old; and they were orphans, he said, with no mother hen to look after their welfare, and yet they were quite able to take care of themselves on water or land. In fair weather they spent most of their time scratching around and picking up a living on the shore, but they recognized 
the boat as their home, and would walk up and down the long gang-plank as carefully and safely as any cautious human being could.

It was the same way with the shanty-boat children, he affirmed. They soon learned the necessities and dangers of the situation and nothing ever happened to them. The bit of deck fore and aft was never protected with railings, and there was naught to prevent the careless child from tumbling overboard; but these children were not careless in that respect and had just as few mishaps as if they lived on land.

Alongshore, neighboring the boats, were many nets, lines, and other fishing-tackle. Some of the men were overhauling their tackle, others were loafing, still others were out in their boats pulling up the lines they had set. Cairo furnished a good market, and there was not the least difficulty in turning a catch of fish into money.

I had a long talk with a farmer whose house was on the bank. He was sitting on his porch reading a newspaper as placid and contented as if he had not a care in the world. The day was pleasant, and everything was favorable for work, and he said he had "right smart of ground to make ready"; but it was Friday, and the week was so far gone he thought it hardly worth while to begin farming until Monday. Besides, he felt obliged to watch the river. It was eating into the bank a few rods away, opposite his house, and the situation was not without danger. 
262 Highways and Byways of the Mississippi Valley

Several houseboats were in view. The man was an old resident, and he knew the river people well. "I been acquainted with a heap of 'em," said he, "and ninety per cent of 'em are as honest and good-hearted as you could ask. It'd surprise you what fine, intelligent people there are among 'em. Now the man in this hyar first boat hyar - his father was one of the leading men in Paducy. He's been well raised and educated and is as refined a man as there is in the country. But he got to drinkin' and so went on the river.

"Another thing that'd surprise you is the amount of money some o' these fellows make - often twenty-five and fifty dollars in a day - yes, sir! If they could ketch fish the year round they'd be millionnaires; but from the end of June to February it's kind o' dull and fish ain't at all plenty. Then, too, when they make money, most of 'em drink it up. Whiskey is the only thing that keeps 'em from gettin' rich."

The shanty-boat men, themselves, did not speak very enthusiastically of their profits. Many fish are caught, but they are not nearly as plentiful as a score of years ago. The law interferes, too, and the boatdwellers cannot catch whenever and wherever they please. For instance, as one man explained, "We ain't allowed in the spring to put wing-nets back in the woods across the lakes and slues where the fish spawn. If we do, the officers raise all sorts of hell with us, 
though they take no notice of the farmers doin' the same sort o' thing."

The autumn is the shanty-boat season. "Sometimes," said the man I have just quoted, "you c'n count ten or fifteen in sight all at the same time floatin' down-stream. Maybe a boat will carry a whole family, movin' with their cows, hogs, and ever'thing, and the household plunder'll be piled all over. But usually thar's only a bunch o' men on board. Perhaps they'll be mechanics. Work has played out an' they're goin' South to hunt; or they got the idee it's too cold up North and they're followin' the summer. Thar's as fine mechanics as thar is in the country gone down past hyar thataway. Wherever night overtakes 'em, they tie up in some little pocket along shore that makes a harbor for 'em, and thar they're at home. It's kind o' risky navigatin' for a greenhorn. You got to look out and not git ketched in a storm and have your boat swamped against the bank, and you got to be careful if you camp on shore whar you stop. First time I was on the river I went down with two other men in a skiff, and afternoons we'd stop about four o'clock and gather up driftwood for a fire and to make a windbreak. Once we stayed in some cottonwoods near which the river made an eddy, and we put up a little hut about fifty feet back from the water; but during the night the bank and big trees all caved off so one corner of our shanty overhung the river. 
264 Highways and Byways of the Mississippi Valley

"When they get down the river the boats ain't worth much. Very likely you can't get more'n thirty-five dollars for a boat that cost a hundred. Lots of 'em are sold for about what they're worth for kindling-wood. But then, if a man is tired of his boat, he's ready to give it away merely to git shet of it. All he wants is to sell for enough money to take him back home; and the next year he may build another and do the very same trick again. I sometimes wonder what becomes of all the shanty-boats. Very few ever go North, and thar's been enough gone down to block up the river from the gulf to Memphis."

To the landspeople of the valley the river is sometimes a demon of destruction; but to the houseboat tribe its aspect is seldom otherwise than friendly. It is a bountiful fairy, a stream of romance full of change and fascination. Whether it rises or falls, it carries the houseboats on its bosom. It is a great highway, and from the borders the boat-dwellers watch its varied traffic. It brings much floating drift from which they can pick whatever is of use to them, and it furnishes easy means of moving to new quarters hundreds of miles away if that is their desire. Elbow room and home comforts are in many ways lacking on the houseboats; and yet people who once adopt the river life seldom abandon it. They gain a living without much trouble, are care-free and bohemian, and there is a charm about the water that keeps them 


\section{Houseboat Life}

content with what, to an outsider, looks like a very rude existence.

Note. - Wherever you stop along the Mississippi be on the watch for the houseboats. They are a perpetual delight to the lover of the picturesque, and the life of their inmates is unfailingly interesting. Indeed, these gypsies of the water seem to stir some primitive impulse in one and keep the fancy on tiptoe. You can, if you choose, build or buy a boat yourself and float with the current down the stream. The most favorable places for seeing the boats, judging from my own experience, are St. Paul, Cairo, Memphis, and Vicksburg. 


\section{XV}

THE HEADWATERS OF THE GREAT RIVER

$\mathrm{N}$ my way north I stopped at those two big thriving cities, St. Paul and Minneapolis, which as they are only ten miles apart barely escape forming a single community. The river had dwindled into a very moderate-sized stream; but at Minneapolis, where it makes the long foaming leap of St. Anthony's Falls, it is still impressive and powerful. The river scenery at the Falls seemed wonderfully wild and chaotic on the uncertain, showery day that I loitered along the stream. There were long strings of booms and floating logs, and there were series of dams and canals and sluiceways, and there were great bridges leaping across the channel in all directions. The banks were lined with immense flour mills and grain elevators and lofty, smoking chimneys, and these structures loomed on the rocky bluffs through the mists and murk, menacing and tremendous. The roar of the waters was in my ears, the throb and rattle of machinery, the shrieking and rushing of the trains as they glided along the verges of the cliffs or across the bridges. Altogether I felt as if this might be the borderland of Hades. 
When I continued my journey I went to the jumpingoff place, that is, to Bemidji, the town farthest north amid the network of lakes which forms the source of the great river. Seven or eight years before this had been the outskirts of the wilderness, invaded by none save a few wandering surveyors, hunters, and lumbermen. Now, Bemidji was a city of four thousand people, and more were constantly coming. New buildings were going up, and you could see the place growing day by day and outspreading itself into the half-savage woodlands. The streets for the most part ran through a forest of Jack pine; but few trees were left in the business centre. There you found rows of stores and saloons and hotels, some of them substantial buildings, and others frail and hasty structures that will soon have to be replaced. There was the same difference in the dwellings. A few were well built and handsome; but a great number were not much more than temporary shelters. Often they rested on wooden blocks, and were banked about with dirt in winter to keep the cold winds from blowing beneath them. The streets of the suburbs were thinly grassed, but the thoroughfares at the centre were rutted sand and dust bestrewn with litter. Conspicuous in the midst of the business section was a swamp with its stagnant pools and rotting logs, its stumps and sprouting of bushes. A great sawmill was the chief source of the town's prosperity, 
268 Highways and Byways of the Mississippi Valley and the place was full of the rough mill-workers and woodsmen.

I got the impression from some of the persons I interviewed that life was held cheap at Bemidji, and that there were frequent drunken quarrels and shootings, and that the saloons were both the social and political centre of the town. "They're never shut," I was told, "and a feller can celebrate here about as he pleases. We want his money, and we won't stand for havin' any man arrested. Yes, this is a wide-open town, and you are free to booze and gamble as long as your cash lasts. You can get any sort of a game you want - shell game, hand game, cards - everything."

This is scarcely the whole truth. The town in its beginning was decidedly tough, but there has been constant and rapid improvement. As one of its leading citizens explained to me, "At first I could almost count on my fingers the inhabitants who had a wholesome respect for law and order. Saloon-keepers and gamblers and their following were in the majority, and drunks were not considered a serious proposition. Yet though you could occasionally see a drunken fight, and though sometimes a man would flourish a gun at another, we have had only a single murder in our history. The fact is, the lumber-jack, unlike the cowboy and miner, rarely carries a gun. He is nevertheless a difficult fellow to deal with. The chief ambition in life of the professional jack is to keep every dis- 
tillery in the United States running to its full capacity. His calling requires a lot of brawn and brute energy, and there is not a harder-working man on earth; but when he comes out of the woods he wants nothing except lawlessness and plenty of whiskey, and he looks for a place where he can spend his money and make his presence known. He used to resort to Bemidji, but since restrictions have been put on his behavior, he has made for smaller towns where he can occupy the centre of the stage. With his going there disappeared many of the low dives he delights to frequent. A half dozen years ago we had forty-six saloons and only two thousand people. Now twice the number of inhabitants get along with thirty saloons.

"Any stranger who visited our town in its rougher days, and heard a jack let out one of his yells, went away and told of the terrible state of affairs existing here, and we have not yet succeeded in living down the fame the town thus acquired. Gambling is about the only serious evil not well under control, and of that there is not one quarter what there was formerly. No, this is not a blood-and-thunder place. It is a natural business centre and has drawn to it an excellent type of citizens, and in many respects we have all the social, religious, and educational advantages that you could get anywhere in a town of its size."

The place even has its Salvation Army. I stopped to listen to a squad of the gospel soldiers one evening. 
270 Highways and Byways of the Mississippi Valley

They had lined up before a brightly lighted saloon with their big drum and tamborine and guitar, and they sang their songs and made their appeals. Right in front of them sat four little girls on the edge of the board walk, evidently fascinated by the uniforms and music; and quite a group of men gathered, attentive and impressed. Yet when the collection was taken up the results were only twelve cents, which I thought the soldiers must find quite disheartening.

The town borders a lake of the same name that is very pretty, with its encircling of green forests and its rafts and rowboats. Sometimes I would hear the tremulous laughter of a loon coming over the water, and lending emphasis to the wildness of the environment.

Where the river enters the lake is a favorite fishing place. A few rods up-stream is a bridge that was occupied all day by a motley crowd watching the lines they had dropped into the current below. Many other fisherfolk, old and young, male and female, were to be seen along the shores or rowing around in the vicinity. Indeed, it seemed, with such a concourse of people intent on the sport, that the fish would be exterminated.

"Oh, no!" responded a fisherman to whom I hinted this fear, "the country here can't be fished out. We got a string of lakes for two hundred and fifty miles and there's breeding-places without number that's 


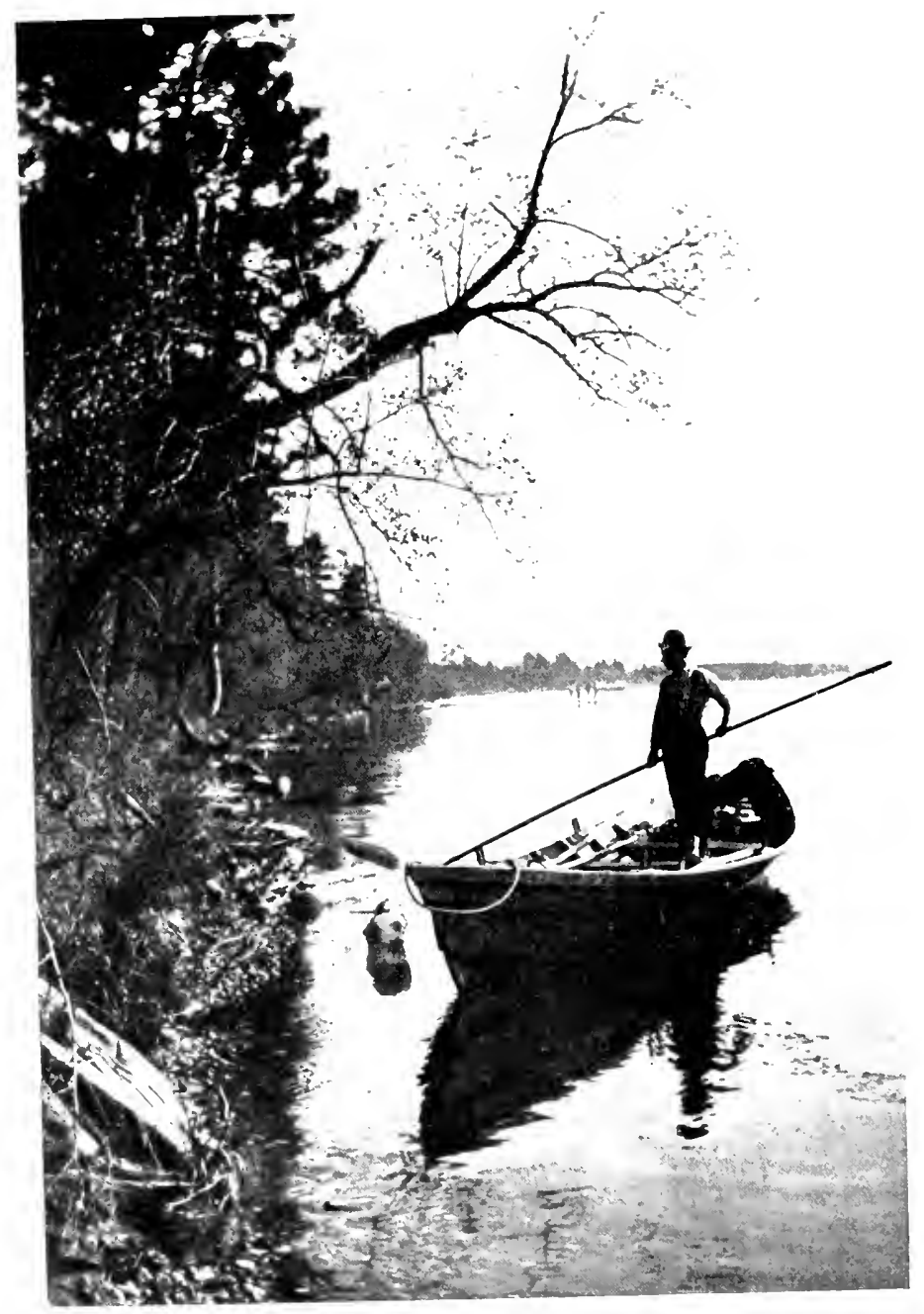

A BathaU 
never disturbed. You won't find no better fishing region in the United States. I've ketched pike here that would weigh seven or eight pounds and pickerel that would weigh twenty pounds. You hardly ever see any one going home with less than a dozen or fifteen pounds of fish, and often three or four times that much.

"You ain't from Chicago, be you? A feller from there was talkin' with me yesterday, and I never met such a crazy chump. He had a little light pole with a reel on to it, and he had a handnet and a fish-basket and all kinds o' flies and fixin's. He was fussin' around the whole time like a settin' hen off its nest, and he tol' me my way of ketchin' fish was jus' butchery and no sport at all. He said you shouldn't pull a fish right out when it got on your hook. His way was to reel it up and let it out and keep on a-foolin' for a quarter of an hour or so before he landed it, even if it was nothin' but a little sunfish."

The river at Bemidji was no more than a creek, crossed by a one-span wooden bridge, yet the distance to the remotest forest lakelet, whence the stream starts, is fully half a hundred miles. One day I followed the river far back into the woods, keeping for the most part to a rough road. The stream, though narrow, ran swift and deep and seemed by no means an unworthy beginning of the mighty river it was to become. It was full of logs ever gliding from above and slipping away beyond sight at the next bend. How smoothly and 


\section{Highways and Byways of the Mississippi Valley}

mysteriously they moved through the silent wilderness, with only a soft plunk, plunk, as they happened to strike one another! Here and there on the bank was a man armed with a pole and canthook, standing guard, ready to act if the logs showed an inclination to form a jam.

I had a chat with one of these men. "The stream here has only been drove six years," he said. "We start the logs every spring as soon as the ice is gone from the lakes, which is about May first, and we're gettin' out more timber this season than ever. That's because the demand and the price has been increasin.' We cut everything now - even balsams and Jack pine. We didn't use to look at anything like that. I presume they do some flim-flam at the mills and tuck in a good deal of it with other better timber and sell it to them that don't know the difference. The logs floatin' down now average pretty poor compared with what they did at first. The class of men we're gettin' in the woods at present to do the cuttin' has something to do with it. They're mostly Scandinavians not long from home, and while they have orders not to cut trees too small or crooked, they ain't got sense to recognize a straight tree when they see it, and don't seem to understand about size."

As far as I went I saw no fine woodland. The choppers had been there before me and left little but ragged brush and sapplings and stumps. The only remnants 
of primeval woods that had escaped at all intact were occasional dark patches of Jack pine. The breeze kept the tall, thickly crowded trees in these groves gently swaying, and whispered in the foliage a mystic vernal melody, as if of mourning over the forest's doom.

As I went on, I began to catch the odor of smoke, and the woodland gradually became quite hazy. At length I passed over a ridge and I could see on ahead glints of flame, and hear the sharp crackling of the fire as it licked up the dry leaves and grasses. The smoke was now dense and choking. I turned aside, hoping to escape from the murk and get around the flames; but I had not gone far when a wind caught the fire and sent it racing over the ground so swiftly and threateningly that I took to my heels. Presently I found another road that led to the opposite side of a lake, and there I met a teamster on his way to town from a logging camp forty miles back in the woods. I concluded I had gone far enough and he invited me to keep him company. He had four horses hitched to a big springless truck wagon, and the ride was no joke. We were on the jolt all the time - now into ruts, now over humps and roots, and now encountering a stump with a sudden collision that would slew the wagon sidewise and threaten to shoot us off from the lofty seat. I hung on for dear life.

"This ain't no asphalt road," said my companion. "It's jus' a tote road, and farther up the valiey it's a dern sight worse than it is here. But you needn't 
274 Highways and Byways of the Mississippi Valley

be afraid; I got the seat wired on so that won't fly off."'

He gave his horses pretty constant encouragement by swearing at them, and now and then launched his long whiplash at them with a startling crack. He told how three weeks previous he had tipped over his load as he was driving across a portion of the road that was flooded. He rescued his goods and extricated himself as well as he could, but was so delayed that night overtook him in the forest.

"Next thing I knew," said he, "I lost the trail and couldn't find it again. So I camped and waited for morning. The wolves got scent of me, and I guess there was a hundred of 'em sneakin' around there. They have a pretty lonesome sort of a howl, and it wa'n't pleasant. Last winter in the chopper's camp we'd hear 'em every night; but they was so shy we didn't often see 'em."

We passed two or three tiny farms carved out of the wilderness. The settlers had ploughed a little land and erected $\log$ cabins accompanied by huddles of diminutive outbuildings. I could discover slight encouragement for agriculture, and said to the driver, "This soil looks too poor and sandy to pay for cultivating."

"Yes," he agreed, "you couldn't raise an umbrella on it, say nothin' of crops. When the lumber is gone the white folks might as well get out of this country and leave it to the Indians. There's a good many 


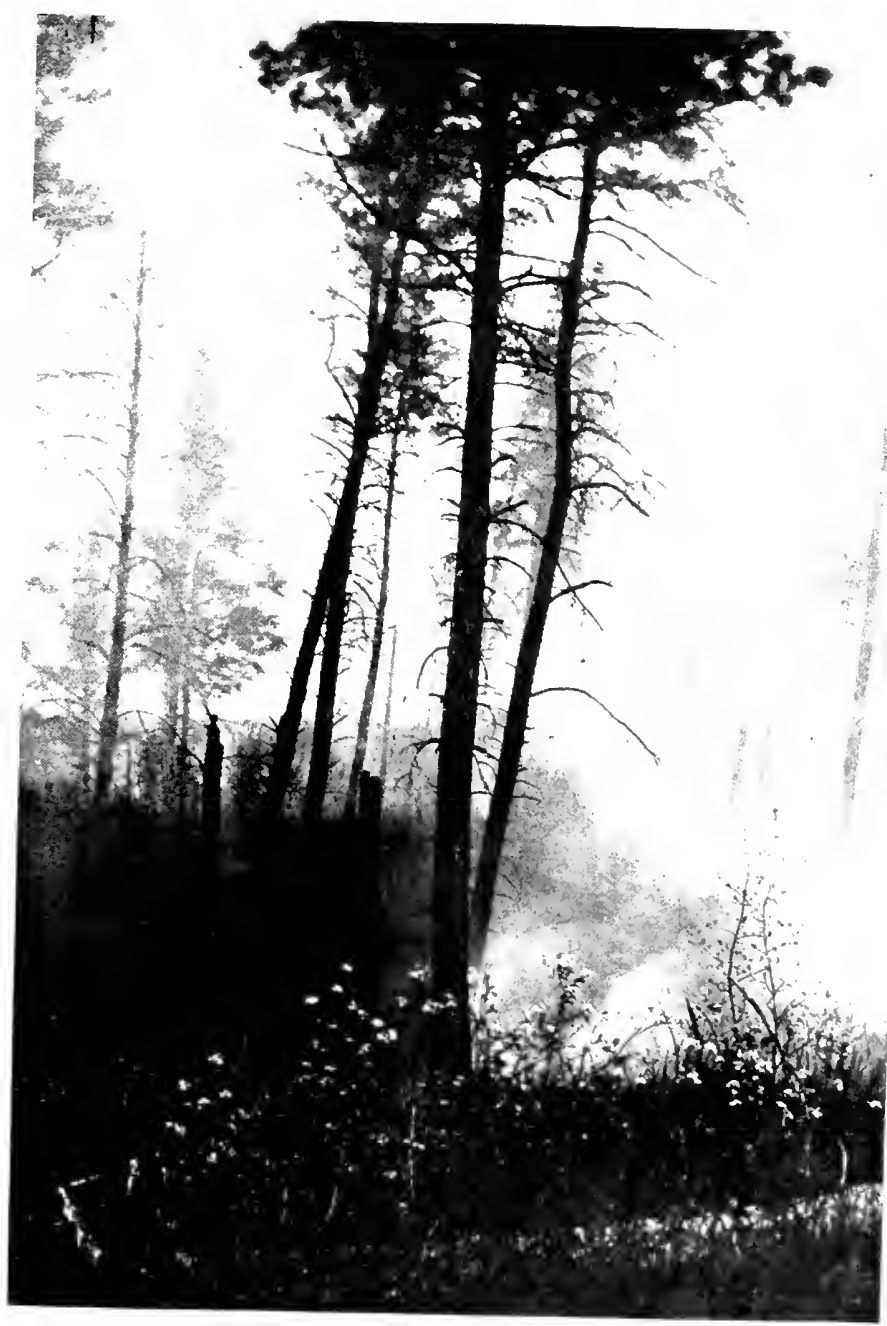

The Fortes Fire 


\section{The Headwaters of the Great River}

Indians workin' on the river, but they ain't steady. Soon as eight or ten dollars is due 'em they're ready to leave. If an Indian sticks to his job any length of time he's got white blood in him. There ain't much industry in the full-bloods. In the first place, they ain't got no strength. Look at the little leg on 'em - jus' about as big as your wrist. All the work they want to do is to hunt and fish. They've been brought up that way, and you can't change 'em. If the government gives an Indian a good house he's pretty apt to put his horse in it and keep on livin' in his wigwam himself. One thing they like to do is to pick wild cranberries and sell 'em in the towns. That job suits'em because while they're pickin' they can be all together having a powwow. They feel good then. They're great hands for stealin' - but I don't know as they're any worse in that respect than people generally. I know whites who, when they get a chance to steal, will only leave what they can't carry off. The Indians ain't so graspin' as that.

"The only time we've had any serious trouble with 'em here was in I898. They had got some whiskey and carried it to their reservation. The marshal followed 'em and tried to make arrests, and they resisted. So the troops was called out, and a drunken commander took a little band of soldiers down in the swamps where the Indians were. One of the men stumbled and his gun went off. Then the Indians thought they was bein' assaulted, and they begun firing from ambush. 
276 Highways and Byways of the Mississippi Valley

A major and nine men was killed; but there was no need of it. They're a poor degraded people, and one white is good for a dozen of 'em if he understands 'em. Yet after that shootin' in the swamps the settlers all around was in a panic, and they built forts out of stumps and $\operatorname{logs}$ and dirt to protect their villages and did all sorts of foolish things."

Everybody in the north country had their ideas about the Indians, and these ideas were not usually very flattering. Probably the fairest opinion expressed to me was that of a man interested in the lumber business, who had been in the region for a third of a century. "I suppose," said he, "you think it's pretty resky livin' where there's so many Indians around; but as far as they are concerned a family is as safe here as in New York City. I've traded with 'em and trusted 'em ever since I've been here and they always do as they say. If they steal it's only for their immediate wants. We sometimes have as much as two thousand dollars' worth of goods in our lumber camp that we leave there without guard after we get through the winter's chopping. The Indians could help themselves easy, but the only thing I ever lost was a five-gallon keg of syrup. Later an Indian came and told me he took it because he had nothin' to eat. He promised to kill me some deer in the fall to pay for it, and he did.

"The Indians don't as a rule cultivate a very close friendship with us. That's partly because they're a 
different kind of people, and partly because their experiences on the frontier with the white men have not been altogether happy. The adventurers who first came into the country were mostly rough and unscrupulous, and all they cared about was to grab what they could for themselves. The impression the Indians got from them of the white race was not very rosy, and though whites of a better class have come in contact with the Indians since, there's plenty of crookedness yet, and I don't blame the Indians for being suspicious."

I became a good deal interested in what I heard of the Indians and decided I would attempt a closer acquaintance with them. There was an Indian settlement down at Cass Lake, and thither I journeyed. I stopped at a town which resembled Bemidji in appearance and in situation, except that it was a mile removed from the lake. On the sandhills near the water was an Indian hamlet of a dozen log cabins dotted irregularly along the ridges, and among them were certain diminutive patches of corn and potatoes, with once in a while a few rows of beets, carrots, and cucumbers. Some dwellings had a little firewood out in front, but never a supply that looked at all thrifty or enterprising. Usually there was a stump handy where fish were cleaned, and the ground about was strewn with fishheads and scales, bits of rabbit fur and duck feathers. At the foot of the sand-bluffs was a shallow well which 


\section{Highways and Byways of the Mississippi Valley}

supplied the entire village. It was roughly boarded around, and was accompanied by a stick with a crotch at one end that was used in lowering and pulling up the pails. The women brought tubs from their cabins and did their washing by the well when the weather permitted. Not far away was a little, mound-shaped wigwam scarcely high enough for a grown person to stand upright in it. The framework was covered with blankets, and pine bushes had been cut and leaned against the sides to keep the blankets in place. There was a fire outside near which a man was squatted scraping the hair off from a deerskin that later would be transformed into moccasins. Beside the man sat a squaw holding a pappoose in her lap. She apparently had some cooking under way, for over the fire hung a pail suspended from a stake thrust slanting into the ground. It was the most rudely primitive family scene I had ever beheld.

$\mathrm{Up}$ in the village I made friends with a young Indian who agreed to take me out to one of the islands in the lake where I could see virgin forest that had never been disturbed by the axe of the choppers. My Indian's name was Ben. He was a flat-chested, slouch-figured fellow, with one shoulder higher than the other and some ugly-looking scars on his neck. These scars, he explained, were the results of a fight of a fortnight previous with another Indian. "I was workin' on the logs then," said Ben, "and he 'n' me was takin' a raft 
down the lake. He got mad and give me two or three cuts with a little knife he had; but I hit him under the chin and knocked him off into the water. I wouldn't let him on to the raft again, and he had to swim to shore. He tol' me as he swum away that he was goin' to kill me, but I ain't seen him since. I sprained my arm fightin' with him, and it ain't strong enough for me to go to work yet."

Ben owned a rowboat, and after padlocking his cabin door he shouldered the oars and led the way across a swampy, brushy meadow to the lake shore. My guide bailed out the boat with a leaky in can and we rowed far out into the lake against the wind and the dashing waves. In certain places the water was beginning to be hidden with sproutings of wild rice, thrusting up from shallows that were sometimes only a few inches deep, and sometimes fully two yards. Later the rice would grow tall and thick and almost impenetrable. In October, when the grain is ripe, the grassy jungles furnish ideal feeding and lurking-places for the ducks and other water fowls. But what is of more importance the wild rice is a staple food of the Indians. Two men in a birch canoe can gather seven or eight bushels in a day. One man sits behind and paddles and the other bends the rice stalks over the boat, first from this side, then from that, and raps them with a stick, and the rice grain comes rattling into the bottom of the canoe.

After the harvest has been secured and carried 
280 Highways and Byways of the Mississippi Valley

home, a fire is built on the ground, and the rice, a little at a time, is put in a kettle and held over the blaze and allowed to scorch slightly. Near by, a hole is scooped and a big kettle set in it. This is filled half full of scorched rice, and a man takes off his shoes and stockings and tramps about in the kettle to loosen the husks. Lastly the grain is transferred to a large pan and winnowed by shaking it in the wind, and then it is stored in sacks ready for use.

When we reached the shore of the island we found a faint footpath, and after following it for a time came to a sheltered glade where the Indians every spring came to make maple sugar. Here was a small shanty in which were great numbers of birch bark sap dishes, and several casks full of spouts. The sap dishes were oblong receptacles that would hold three or four quarts. The bent-up ends were tied in place with thongs of basswood bark, and slight cracks and holes were mended with pitch. The spouts were split out of cedar, and were a foot long, two inches broad, and one-fourth of an inch thick. They were slightly rounded and sharpened to a flat edge at one end. The trees were tapped by making a $V$-shaped cut with an axe, below which an incision was made with a round-edged chisel to receive the spout. The sugar which the Indians manufacture is finely granulated and is put up in stout birch bark receptacles shaped like a fish basket, with a bulging bottom and a neat cover. These baskets hold about 


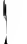




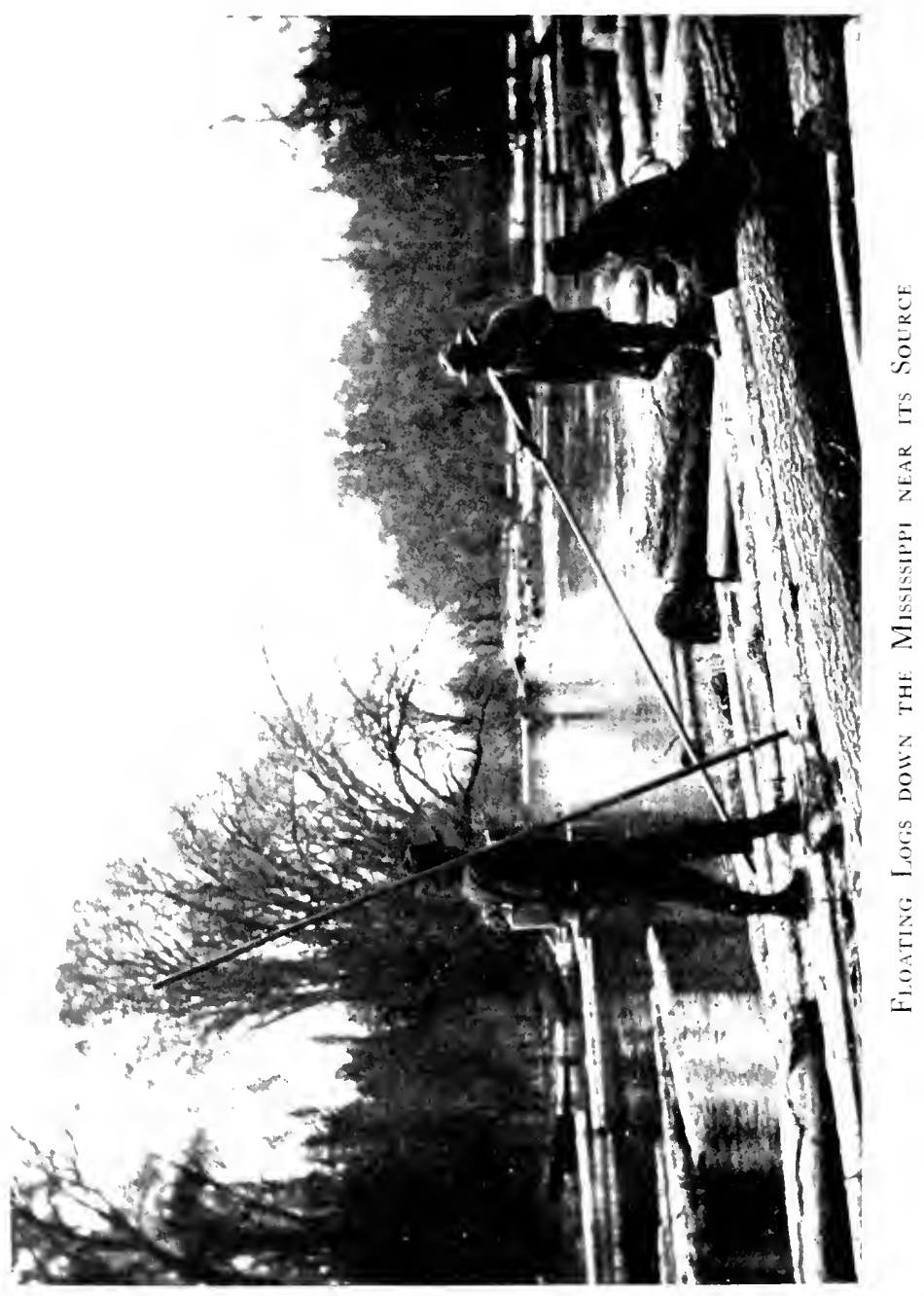


sixty pounds each. Quite a party, including squaws as well as men, worked together and made the maple woods their home while the sap run lasted.

This portion of the island was grown up to hardwood, but farther on were pines, tall and straight and clean-trunked, worthy pillars of the forest temple. There was a light undergrowth of saplings, and many fallen tree trunks, upturned roots, and a tangle of dead branches. Quiet reigned, and the sunlight flickered down through the tree-tops on to the thin green foliage of the undergrowth, and the thought that the aspect of it all had hardly changed for centuries made the scene doubly impressive.

On our way back to the mainland we skirted another island and stopped to see the deserted camp of an Indian family. The shore was low and wet, and there were streaks of bushes, and occasional trees. Under one of the trees where the ground was a trifle higher than that round about was the frame of a conical wigwam. The family had evidently left the day before, and back in the bushes were some of their household goods covered with bagging, and under another clump was a birch canoe. Ben poked around to see what treasures he could find. He removed the strings from a pair of discarded shoes, and he picked up and pocketed a safety-pin which he spoke of as "a squaw pin." I did not wonder the Indians had moved. There were remnants of fish all about, from which pestiferous clouds 
282 Highways and Byways of the Mississippi Valley

of flies arose wherever we went, and the stench was insufferable.

We soon embarked once more and resumed our rowing, and presently arrived at the spot where we started.

On another occasion Ben and I went together six miles into the wilderness along the lakeshore to a village on an Indian reservation. We followed a narrow path that dodged along through the bushes and that constantly turned and twisted to avoid irregularities of the ground and whatever obstructions the forest growths made. Some of the detours were quite recent and were necessitated by a fallen tree-top that one could not easily step over or go under. Such obstructions could usually have been removed in a few moments by a man with an axe; but the trailmakers preferred to go around rather than exert themselves to improve the path. Travelling was no hardship where we had solid ground under foot. It was another matter when the route led through swampy hollows and we had to jump along on tufts and roots and rotting tree fragments. Ben was inclined to be contemplative and silent. He replied readily to questions, but he had the racial taciturnity. It was evident, however, that the woods were his ancestral home, and that he felt more free and easy there than anywhere else. Little incidents were constantly occurring that showed his real interests and half-wild characteristics. Once we encountered a couple of inoffensive calves in our path. They looked at us inquiringly, and 
Ben made a sudden run at them, and chuckled gleefully as they hurry-skurried off into the bushes. Sometimes he would point to certain tracks in the path - a dog's footprint, the mark of a moccasin, or whatever it might be, and study on its significance. Once he called my attention to a rude figure of an Indian cut in the bark of a tree by his father; but it was devoid of any purpose. We heard the partridges drumming and Ben stopped to listen. A squirrel ran up a tree and sat on a limb regarding us alertly. Ben, delighted with the sight, called to it in his native language and got out a pistol from his hip pocket. Luckily, he had no cartridges; yet he took careful aim and snapped the harmless weapon and exulted in the thought of what would have happened had it been loaded. I asked him about some of the birds we heard singing, but he could not tell me their names, except that they were "canaries and other birds."

At length we came to the outskirts of the Indian village. Some of the cabins were very well placed on hills that afforded a wide view over the forest and marshes, and over the inlets and broad expanses of the lake. They were much scattered, and the woods intervening between the little clearings shut them away from sight of each other. Most of them were beyond a stream a dozen rods broad that connected two sections of the lake. At the mouth of the stream was a boom of $\operatorname{logs}$, and there was no way for us to get 
284 Highways and Byways of the Mississippi Valley

across except by walking on that. It was precarious footing; but we made the passage in safety, and Ben even stopped midway to look at some large fish lazily breasting the current. "Gee!" he said, "I wish I had them."

"Gee," was his favorite exclamation, though he sometimes used terms more coarse and violent.

In a grove on one of the hills was a government school. A man and wife educated at Carlisle had charge, and there were about forty children in their care. The main building was a large, well-built, clapboarded structure, and round about were various log barns and sheds. It is an industrial school, and besides book education the boy pupils learn how to care for cows and horses and do gardening, and the girls learn to sew and do housework. The children are allowed to visit their homes frequently, but are urged not to stay long. If they do, their health is apt to suffer, especially in winter; for the home huts are very hot and very cold by spells, and not at all hygienic. Some of the children accommodate themselves readily to school life and discipline and others do not. Ben said he tried it once, but he had to take care of horses the whole time, and he didn't like that job, and quit. The boys and girls were wandering in the woods and by the waters, and I thought they seemed to be having a very free and easy time; but perhaps it is best that way. A gray-haired, bareheaded old Indian lay under one of the trees close to 
the school smoking a large red pipe shaped like a hammer. There he reclined, stoical and contented, puffing away with much the same peace of mind and enjoyment that a cow has in chewing its cud.

Ben had two sisters ten and twelve years of age among the pupils, and they returned with us. They were vigorous and erect, bright-eyed and attractive; and they were neatly clothed, but did not put on any head covering. When we came to the stream we all walked the boom. Ben escorted the girls one at a time along the wobbly logs; but the older maiden when she neared the end of the boom ran on alone as nimble as a squirrel and made a five-foot jump to the shore. The girls now took the lead and swung along at such a rapid walk I sometimes had to take a little run to keep up. It was a great delight to them to get away from the school, and they chattered and laughed, and picked and ate some of the abounding wintergreen berries. In the swampy glades they gathered great bunches of cowslips, which they were doubtful whether to call buttercups or water lilies. They tired of carrying them after a time, but instead of throwing them carelessly down they set them upright on the ground as if the flowers had grown there. The mosquitoes swarmed in the woods everywhere, and the younger girl partially protected herself from them by putting her apron over her head. Ben gave his hat to the other to wear.

I parted with my companions at the Indian village 
286 Highways and Byways of the Mississippi Valley

and continued on up to the town where I rested for a time and refreshed myself with a square meal. Then I went for a ramble about the streets. It was evening - very quiet and warm, and the atmosphere was dull with haze from forest fires and pungent with dust. Every one was outdoors. The young men were playing ball; the children were running, laughing, shouting, and disputing; and their elders sat at the house-fronts visiting. The mosquitoes had invaded the town, and smudges had been resorted to quite freely to fend off the pests. I even saw a smudge on the windward side of two cows in a little enclosure back of one of the $\log$ houses. The cows stood where they received the full benefit of the smoke and seemed quite grateful for it. Some of the houses had been smudged out and then closed up, and the inmates awaited bedtime sitting outside gathered about the smudge pail. I joined one of these groups, which included two or three neighbors besides the home family. The sun, a great ruddy orb, was sinking behind the pine woods in the west, and the sky above it was flushed with rosy color that faded into saffron and light yellow, and then into softest blue.

When the sun had disappeared and the twilight had grown dim, one of the neighbor women of our group rose leisurely and said, "Gosh! I must go home."

Night was gathering over the ragged little town on the sands, and the gloom of the serrated forest that 



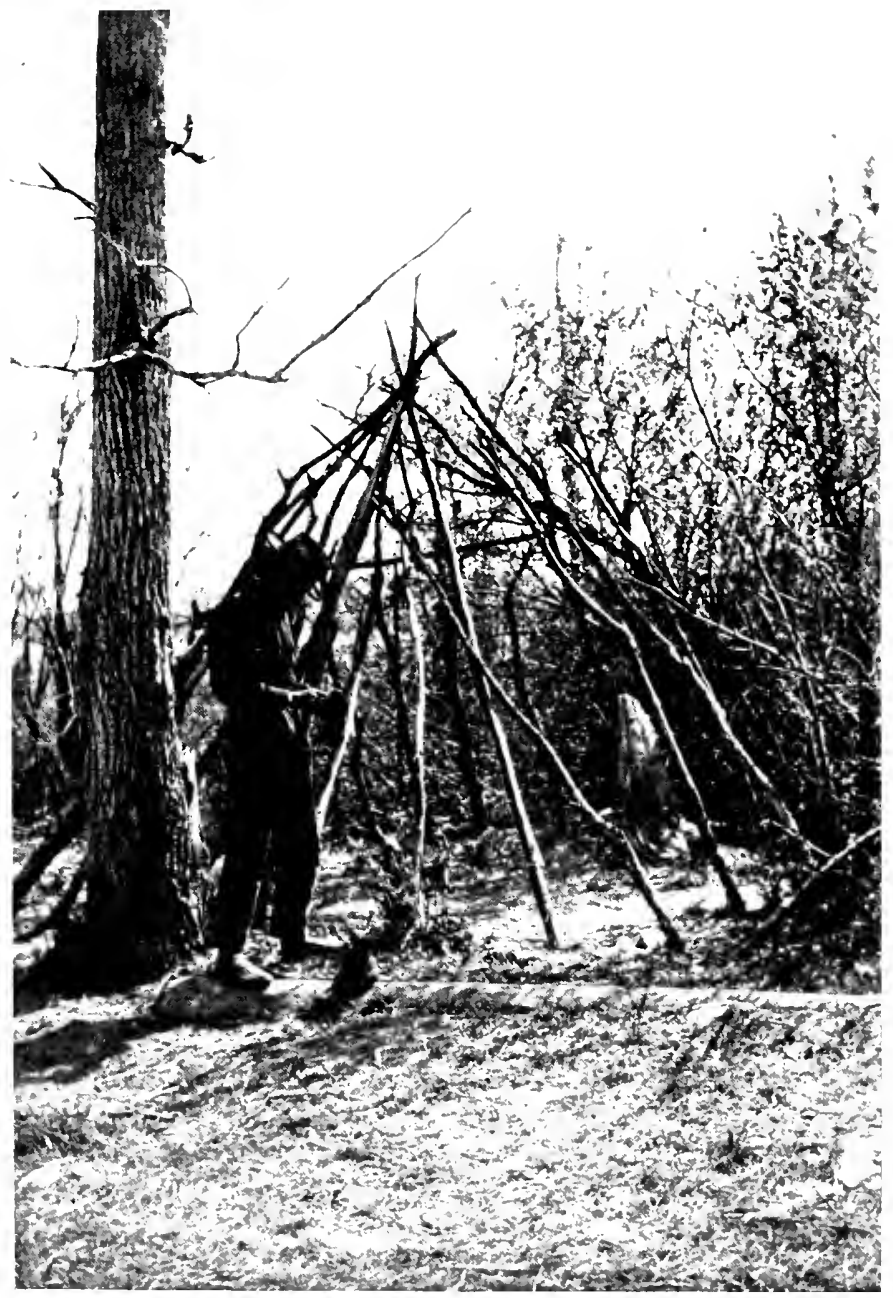

The Frane of an Indan Whawam 
hemmed it in on every side was deepening into blackness. The children were going indoors, the ball games had ceased, and soon the vast silence of the wilderness was almost unbroken.

Note. - Here is tourist country to make one happy - forest and Indians and lakes and streams and most wonderful fishing. There are hotels, too, which, if not palatial, are at least comfortable; and yet you are where only a few years ago was almost uninhabited wilderness. What if a good deal of rawness still shows itself in the towns - that is to be expected and only adds zest to the situation and makes the appeal to the traveller stronger. This northern country for many reasons deserves the attention of tourists, especially those from regions long settled, where conditions have taken on permanence, and where the beginnings are dim with remoteness. 


\section{HIGHWAYS AND BYWAYS OF THE SOUTH}

\section{With over 100 illustrations. Cloth. Crown 8vo. \$2.00 net}

"Mr. Clifton Johnson is constantly entertaining and no less constantly instructive. A keen observer, he knows exactly how to describe the scenes he visits and the people he meets. His pen, indeed, is scarcely less photographic than his excellent camera." - Boston Butget.

"Abounds in glimpses, not of the country only, but as well of the life and unique characteristics of the people, especially what may be termed the common people. The narratives, never at all elaborate, the bits of description and of variously familiar and artless conversations, together with the admirable illustrations taken from his own snapshots, give to the reader a surprisingly realistic sense of things, especially in unfamiliar parts of the country. All this is done in a facile, genial, and broadly sympathetic spirit." - Chicago Tribune.

\section{NEW ENGLAND AND ITS NEIGHBORS}

\section{With over 100 illustrations. Cloth. Crown 8vo. \$2.00 net}

"A simple, natural, rambling record of rural Yankeedom, picturing to the very life the ways and habits, the conversation, the whimsicalities, of the people of the smaller villages and farmhouses of the northeastern portion of the United States, and the illustrations carry out the spirit of the text perfectly." - New York Commercial Advertiser.

"A book that ranks with the best in the author's long list of entertaining and picturesque books. Every phase of the New Englander's existence is touched, and one feels he is listening to a sympathetic interpreter of things. Mr. Johnson's literary style is direct, and his word-pictures vivid. The result is a book that will doubtless long give delight."

- Denver Republican.

\section{THE MACMILLAN COMPANY \\ 64-66 Fifth Avenue, New York}




\section{AMONG ENGLISH HEDGEROWS}

With an Introduction by Hamilton W. Mabie, and over 100 Illustrations. $\quad \$ 2.25$

"The book deserves to succeed, not only in America, but in the country which it so lovingly depicts." - The Spectator, London.

" The chief charm of Mr. Johnson's work lies in the enchanting simplicity with which he records the manners and customs of the country." - The Nation.

\section{ALONG FRENCH BYWAYS}

Fully Illustrated. $\quad \$ 2.25$

" Gives a singularly faithful and complete and well-balanced idea of the French peasantry and French rural life, manners, and customs." - Boston Herald.

"We follow our guide with deepening interest to the end of his tour. His pictures are charming and so is the whole book."

\section{- London Quarterly Review.}

\section{THE ISLE OF THE SHAMROCK}

Fully Illustrated. $\$ 2.00$ net; postage, 15 cents " A most interesting book, full of lively sketches and anecdotes." - London Daily Nezus.

"One of the most informing books about Ireland and the conditions of the Irish folk in the country and small towns that has been published in a long time." - Brooklyn Eagle.

\section{THE MACMILLAN COMPANY 64-66 Fifth Avenue, New York}




\section{OTHER BOOKS BY CLIFTON JOHNSON \\ THE LAND OF HEATHER}

Fully Illustrated. $\$ \mathbf{2 . 0 0}$ net; postage, 15 cents

" Mr. Johnson is a keen observer and has the literary gift of apt expression in a marked degree.'

- Dundee (Scotland) Advertiser.

"Not only Scotchmen, but every student of human nature will be pleased with this entertaining book. It describes typical people and scenes with much sympathy and appreciation."

- Brooklyn Standard Union.

\section{Old-time Schools and School-books}

\section{With 234 Illustrations. $\$ 2.00$ net; postage, 20 cents}

"A storehouse of delightfully quaint reprints of texts and cuts, and a mine of information concerning educational beginnings in this country." -Tbe Outlook.

"Mr. Johnson has made a most entertaining volume. Few professionally humorous books contain so much that is genuinely funny." - Providence Journal.

Edited by CLIFTON JOHNSON for School and Home Reading

\section{DON QUIXOTE}

\section{lllustrated by Cruikshank. 75 cents}

" An admirable piece of editing has been done by Clifton Johnson. He has omitted the obnoxious portions and many of the unpleasant details which made the original objectionable. The result is a pleasant, readable story, in every way wholesome and attractive." - The Cbautauquan.

\section{THE MACMILLAN COMPANY 64-66 Fifth Avenue, New York}







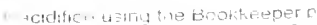
Neutrahz, Acent Marmisum. Dxud Tieamont Date

(5)

U| 



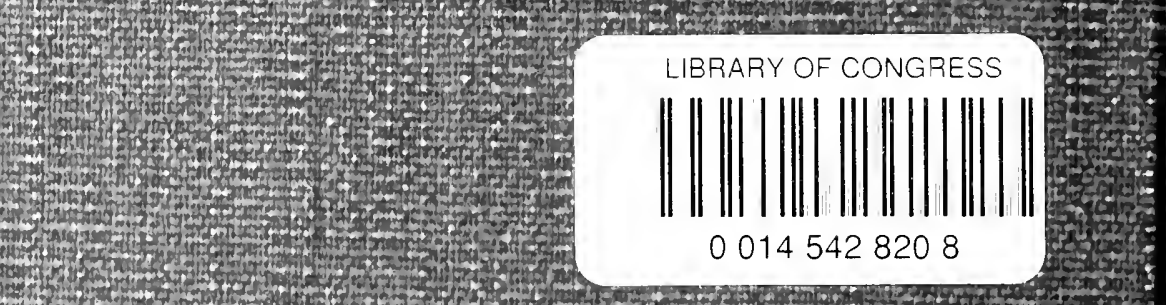

